PROCEDIMENTALIZAÇÃO NOS CONSELHOS DE POLÍTICAS PÚBLICAS: O CASO DO CONSELHO MUNICIPAL DE HABITAÇÃO DE SÃO PAULO

Dissertação de Mestrado

Orientador: Professor Dr. Gustavo Justino de Oliveira

UNIVERSIDADE DE SÃO PAULO

FACULDADE DE DIREITO

São Paulo - SP

2015 


\title{
PROCEDIMENTALIZAÇÃO NOS CONSELHOS DE POLÍTICAS PÚBLICAS: O CASO DO CONSELHO MUNICIPAL DE HABITAÇÃO DE SÃO PAULO
}

\begin{abstract}
Dissertação apresentada à Banca Examinadora do Programa de Pós-Graduação em Direito, da Faculdade de Direito da Universidade de São Paulo, como exigência parcial para obtenção do título de Mestre em Direito, na área de concentração Direito do Estado, sob orientação do Prof. Dr. Gustavo Justino de Oliveira.
\end{abstract}

UNIVERSIDADE DE SÃO PAULO

FACULDADE DE DIREITO

São Paulo - SP

2015 
Catalogação da Publicação Serviço de Biblioteca e Documentação

Faculdade de Direito da Universidade de São Paulo

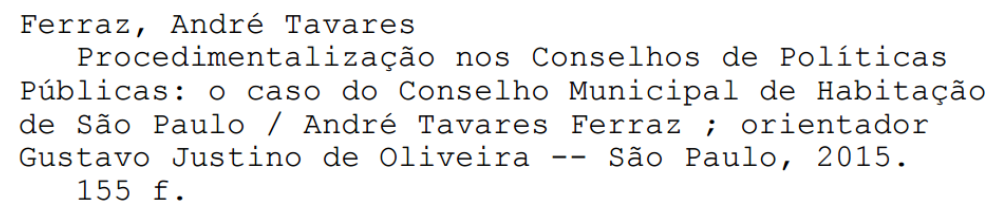

Dissertação (Mestrado - Programa de Pós-Graduação em Direito do Estado) - Faculdade de Direito, Universidade de São Paulo, 2015.

1. Conselhos Municipais de Políticas Públicas. 2. Democracia participativa. 3. Políticas públicas. 4. Processo administrativo. 5. Processo orçamentário. I. Oliveira, Gustavo Justino de, orient. II. Título. 
Nome: André Tavares Ferraz

Título: Procedimentalização nos Conselhos de Políticas Públicas: o caso do Conselho Municipal de Habitação de São Paulo

Dissertação apresentada à Banca Examinadora do Programa de Pós-Graduação em Direito, da Faculdade de Direito da Universidade de São Paulo, como exigência parcial para obtenção do título de Mestre em Direito, na área de concentração Direito do Estado, sob orientação do Prof. Dr. Gustavo Justino de Oliveira.

Aprovado em: .....................

\section{$\underline{\text { Banca examinadora }}$}

Prof. Dr. Gustavo Justino de Oliveira

(Orientador)

$1^{\circ}$ Examinador

$2^{\circ}$ Examinador 
Vidro moído ou areia

No café da manhã

E um sorriso nos lábios

Ensopadinho de pedra

No almoço e jantar

E um sorriso nos lábios

O sangue, o roubo, a morte

Um negro em cada jornal

E um sorriso nos lábios

Noventa e cinco sorrisos

Suando na condução

E um sorriso nos lábios...

Mas sonha que passa

Ou toma cachaça

Aguenta firme, irmão

Na oração

Deus tudo vê e Deus dará

Ou então acha graça

É tão pouca a desgraça

Mas no fim do mês

Lembra de pagar a prestação

Desse sorriso nos lábios, é Desse sorriso nos lábios, pois é

Desse sorriso nos lábios...

Música "Um sorriso nos lábios” de Gonzaguinha

Para que $(m)$ serve teu conhecimento?

Autoria desconhecida 


\section{AGRADECIMENTOS}

Gostaria de agradecer a todos os que direta ou indiretamente me auxiliaram na concepção, desenvolvimento e conclusão desta pesquisa.

Ao meu orientador, Professor Gustavo Justino de Oliveira, meu agradecimento especial, por me oferecer uma visão acadêmica interdisciplinar, renovadora e atual do direito; pelos ensinamentos colhidos durante o rico processo de concepção e desenvolvimento da pesquisa. Agradeço ainda pela confiança e oportunidade oferecidas, e pela paciente e atenta condução da orientação sem as quais este trabalho não seria possível.

Às professoras Natasha Schimtt Cassia Salinas e Maria Paula Dallari Bucci, pelas valiosas contribuições e reflexões, apresentadas na qualificação do projeto de dissertação, que muito serviram para o amadurecimento da pesquisa.

Aos bibliotecários desta Faculdade de Direito, especialmente, Ivan e Raquel, com os quais convivi, com frequência, pelo pronto e sempre competente auxílio no levantamento do material bibliográfico nestes três anos de mestrado.

Aos membros do Conselho Municipal de Habitação de São Paulo, especialmente, o Sr. Benedito Barbosa ou Sr. Dito, e aos funcionários da Prefeitura Municipal de São Paulo, pelas gentis entrevistas concedidas e pelo esclarecimento de questões essenciais ao adequado direcionamento da pesquisa.

Ao desembargador Paulo Magalhães da Costa Coelho pelos ensinamentos de uma visão de mundo mais humana, justa e solidária, como pessoa e profissional; e pela compreensão e apoio que muito favoreceram a boa conclusão deste trabalho.

Por fim, à minha família, especialmente minha mãe, Irene Tavares, e à minha companhia de vida, Ana Paula, agradeço-lhes o apoio diário, a compreensão e o amor, sobretudo nos inúmeros momentos de reclusão para o desenvolvimento da pesquisa e pelos incentivos nos momentos mais difíceis.

A todos e todas, meu muito obrigado. 


\section{RESUMO}

FERRAZ, André Tavares. Procedimentalização nos Conselhos de Políticas Públicas: o caso do Conselho Municipal de Habitação de São Paulo. 2015. 155 f. Mestrado, Faculdade de Direito, Universidade de São Paulo, São Paulo, 2015.

A presente pesquisa tem como objetivo geral analisar a procedimentalização nos Conselhos Municipais de Políticas Públicas, isto é, analisar o regime jurídico dos procedimentos administrativos aplicáveis aos Conselhos, bem como o modo de participação dos Conselhos no processo orçamentário municipal de São Paulo. Embora existam há mais de duas décadas, a revisão da literatura indica que os Conselhos em geral têm se destacado mais como instâncias de físcalização do que de planejamento de políticas públicas. Como objetivos específicos, a pesquisa pretendeu averiguar a adequação dos procedimentos administrativos que regem o Conselho Municipal de Habitação de São Paulo (CMH) e analisar sua participação no processo orçamentário municipal com base na Análise de Conteúdo das Atas de Reunião de 2003 a 2015. Como resultado, a pesquisa identificou que o CMH não elaborou nem aprovou, desde o início, nenhuma das propostas orçamentárias (PPA, LDO e LOA) do Fundo Municipal de Habitação (FMH), nas quais se formalizam as diretrizes, metas, programas habitacionais e planos de aplicação de recursos do Fundo, ao contrário do que dispõe a Lei Municipal 13.425/02. Na fase de execução orçamentária, foi possível perceber que o Conselho tem atuado, quase exclusivamente, como agente gestor do Fundo, apreciando e aprovando previamente as propostas de operações (projetos e atividades) a implementar. Além disso, a pesquisa evidenciou que o processo decisório do $\mathrm{CMH}$ tem se desenvolvido sem o necessário esclarecimento e sem a adequada instrução processual, principalmente, no que diz respeito ao direito à ampla defesa e à produção de provas pelos conselheiros. A pesquisa concluiu que o CMH deveria agir, com maior ênfase, no planejamento e elaboração das propostas orçamentárias na fase de elaboração da política pública; e como órgão de fiscalização, monitoramento e avaliação na fase de implementação da política pública, estas, afinal, sua vocação institucional; ao invés de atuar como agente operador do Fundo, que pressupõe competências legais e administrativas estranhas ao Conselho.

Palavras-chave: Conselhos Municipais de Políticas Públicas; democracia participativa; participação popular; processo administrativo; processo orçamentário. 


\begin{abstract}
FERRAZ, André Tavares. Proceduralization in the Public Policy Councils: case study of Conselho Municipal de Habitação de São Paulo. 2015. 155 f. Master, Faculty of Law, University of São Paulo, São Paulo, 2015.

This research has the general objective of analyzing the proceduralization in the Municipal Public Policy Councils, it means, analyze the legal regime of administrative procedures of Councils as well as the mode of participation of the Councils in the São Paulo's municipal budget process. Although there are more than two decades, the literature review indicates that the Councils in general have stood out more as supervisory bodies than in the public policy planning. As specific objectives, the research intended to verify the adequacy of the administrative procedures governing the Conselho Municipal de Habitação de São Paulo $(\mathrm{CMH})$ and analyze their participation in municipal budgeting process based on the Content Analysis of the Minutes of Meetings of 2003-2015. As result, the survey also found that the $\mathrm{CMH}$, since the beginning, did not made or approved none of the budget proposals (PPA, LDO and LOA) of Fundo Municipal de Habitação (FMH), in which the guidelines, goals, housing programs and plans application of Fund are formalized, against the Municipal Law $13,425 / 02$. In the budget execution phase, was possible to realize that the $\mathrm{CMH}$ has worked almost exclusively as Fund manager agent, appreciating and previously approving the concrete operations (projects and activities) to implement. In addition, the research showed that the CMH's decision-making process has not been observing the proper right of notice and comment, especially about the right to comment and offer evidences by the counselors. The research concluded that the $\mathrm{CMH}$ should act with greater emphasis in the planning and preparation of the budget proposals at the stage of elaboration of public policies; and as a supervisory body, monitoring and evaluation at the implementation phase of public policy, these, after all, your institutional vocation; instead of acting as manager agent of the Fund, which presupposes legal and administrative expertise out of the Council.
\end{abstract}

Palavras-chave: Public Policy Councils; participatory democracy; public participation; administrative procedure; budget process. 


\section{LISTA DE FIGURAS E TABELAS}

Esquema 1 - Instâncias de participação popular $\quad 88$

Esquema 2 - Participação do CMH na fase de elaboração da proposta orçamentária 117

Esquema 3 - Participação do CMH na fase de execução orçamentária 120 


\section{LISTA DE ABREVIATURAS E SIGLAS}

CF - Constituição Federal de 1988

CECMH - Comissão Executiva do Conselho Municipal de Habitação de São Paulo

CMH - Conselho Municipal de Habitação de São Paulo

CMDCA - Conselho Municipal dos Direitos da Criança e do Adolescente

CMPU - Conselho Municipal de Política Urbana de São Paulo

COHAB-SP - Companhia Metropolitana de Habitação de São Paulo

CPC - Lei n. ${ }^{\circ}$ 5.869, de 11 de janeiro de 1973 (Código de Processo Civil)

DOCSP - Diário Oficial da Cidade de São Paulo

FMH - Fundo Municipal de Habitação de São Paulo

FUNDURB - Fundo Municipal de Desenvolvimento Urbano de São Paulo

GT - Grupo de Trabalho

GP - Grupo de Planejamento

HIS - Habitação de Interesse Social

IBGE - Instituto Brasileiro de Geografia e Estatística

LDO - Lei de Diretrizes Orçamentárias

LOA - Lei do Orçamento Anual

LOMSP - Lei Orgânica do Município de São Paulo

LPAE - Lei Estadual 10.177, de 30 de dezembro de 1998 (Lei de Processo Administrativo do Estado de São Paulo).

LPAF - Lei Federal 9.784, de 29 de janeiro de 1999 (Lei de Processo Administrativo Federal)

LPAM - Lei Municipal 14.141, de 27 de março de 2006 (Lei de Processo Administrativo do Município de São Paulo).

PDE - Plano Diretor Estratégico

PPA - Plano Plurianual

SEHAB - Secretaria Municipal de Habitação de São Paulo

SF - Secretaria Municipal de Finanças e Desenvolvimento Econômico de São Paulo

STF - Supremo Tribunal Federal

STJ - Superior Tribunal de Justiça

TJSP - Tribunal de Justiça do Estado de São Paulo 


\section{SUMÁRIO}

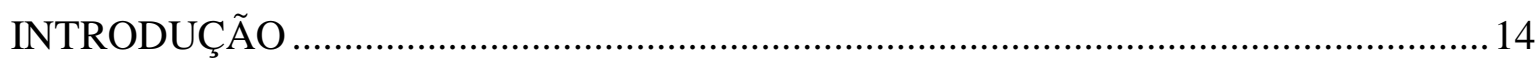

1 DESENHO DA PESQUISA E METODOLOGIA …………………………………...... 18

1.1 PROBLEMATIZAÇÃO E DELIMITAÇÃO DO TEMA DE PESQUISA ................ 18

1.2 OBJETIVOS E QUESTÕES DA PESQUISA ……………................................... 19

1.3 MÉTODO DE PESQUISA: ESTUDO DE CASO …………………………….......20

1.4 TÉCNICA DE COLETA E ANÁLISE DE DADOS …………………………..........2

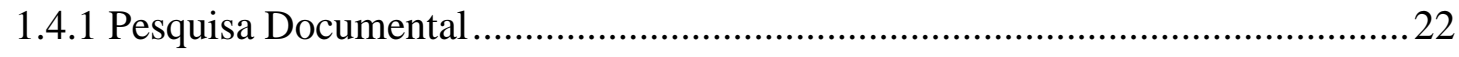

1.4.2 Análise de Conteúdo .......................................................................................2

2 CONSELHOS MUNICIPAIS DE POLÍTICAS

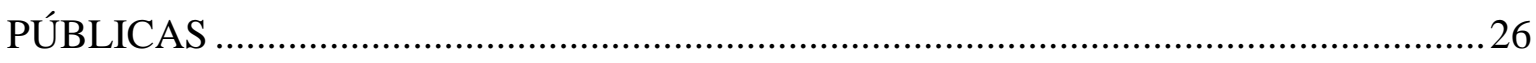

2.1 A DEMOCRACIA PARTICIPATIVA NA ATUALIDADE ...................................26

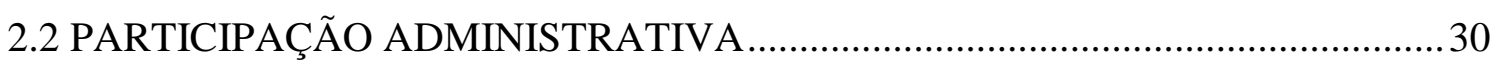

2.3 PARTICIPAÇÃO POPULAR NA TRANSIÇÃO DEMOCRÁTICA: A ORIGEM DOS CONSELHOS MUNICIPAIS DE POLÍTICAS PÚBLICAS ……………….......... 32 2.4 NATUREZA JURÍDICA, ATRIBUIÇÕES E DISCRICIONARIEDADE DOS CONSELHOS MUNICIPAIS DE POLÍTICAS PÚBLICAS ……………………….......4 40

2.5 OS PROCEDIMENTOS ADMINISTRATIVOS E O PROCESSO ORÇAMENTÁRIO NOS CONSELHOS: OBJETOS DE PESQUISA ………………......46

3 REGIME JURÍDICO DOS PROCEDIMENTOS ADMINISTRATIVOS APLICÁVEIS

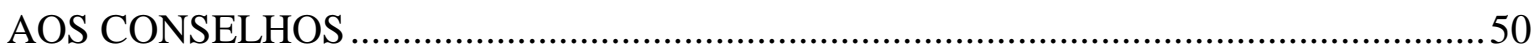

3.1 PROCEDIMENTALIZAÇÃO DA ATIVIDADE ADMINISTRATIVA ...................50

3.2 PROCESSO OU PROCEDIMENTO ADMINISTRATIVO ....................................53

3.3 PRINCÍPIOS DO PROCEDIMENTO (PROCESSO) ADMINISTRATIVO .............54

3.3.1 Princípio do devido processo legal ou do formalismo moderado..........................54

3.3.2 Princípio da igualdade, impessoalidade ou imparcialidade ..................................5

3.3.3 Princípio do inquisitório, impulso oficial ou da oficialidade.................................57

3.3.4 Princípios do contraditório e da ampla defesa ...................................................58

3.3.5 Princípio da motivação ou da fundamentação …………………………………....59

3.4 ETAPAS DO PROCEDIMENTO ADMINISTRATIVO NOS CONSELHOS .........60

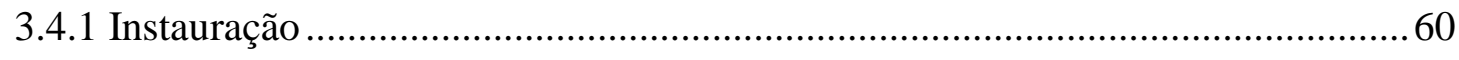

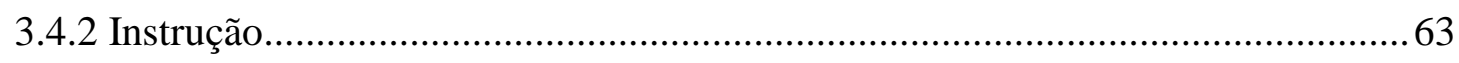


3.4.3 Decisão. 69

4 A PARTICIPAÇÃO DOS CONSELHOS NO PROCESSO ORÇAMENTÁRIO

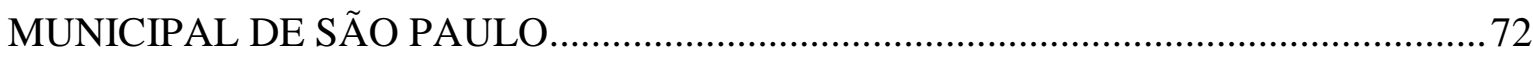

4.1 CICLO DE FORMAÇÃO DAS POLÍTICAS PÚBLICAS (POLICY CICLE) ..........72

4.2 POLÍTICAS PÚBLICAS NA PERSPECTIVA JURÍDICA …................................. 77

4.3 CONSELHOS E PROCESSO ORÇAMENTÁRIO MUNICIPAL SEGUNDO A LEI

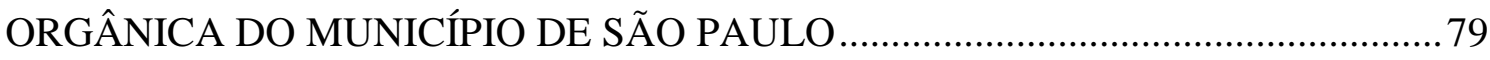

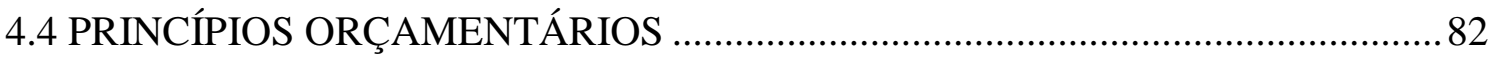

4.4.1 Princípios da unidade, da universalidade e da especificação............................. 82

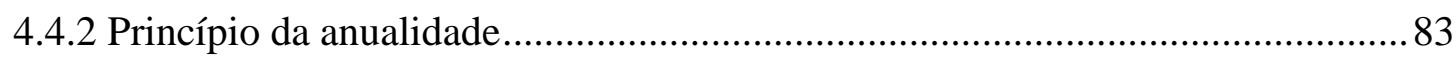

4.4.3 Princípio da transparência e da gestão democrática das cidades ........................83

4.5 INSTRUMENTOS DE PLANEJAMENTO URBANO E ORÇAMENTO

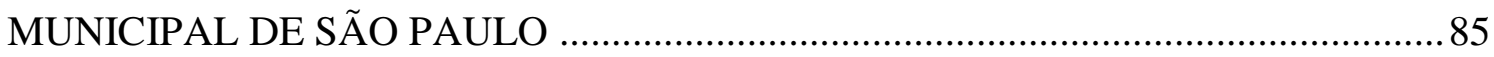

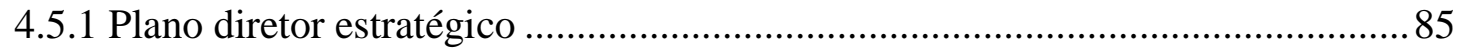

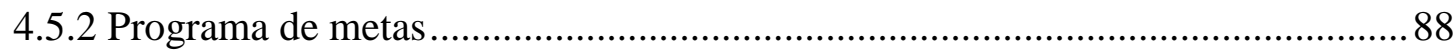

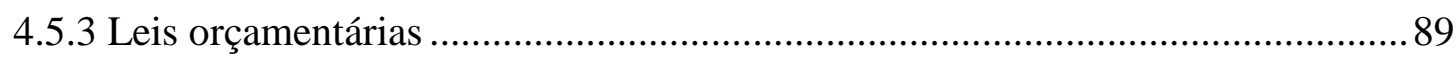

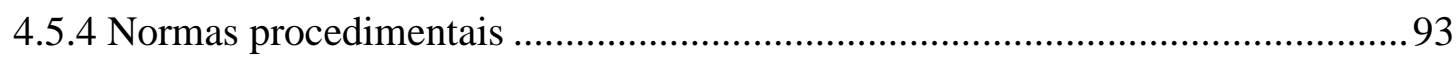

4.6 REGIME FINANCEIRO DOS FUNDOS ESPECIAIS ........................................... 97

5 ESTUDO DE CASO: O PROCESSO ORÇAMENTÁRIO MUNICIPAL E OS

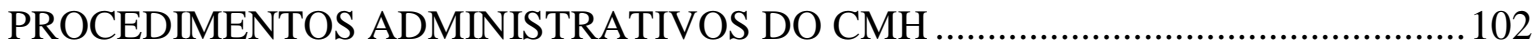

5.1 ESTRUTURA ORGANIZACIONAL E COMPETÊNCIAS DO CMH ................... 102

5.1.1 Conselho Municipal de Habitação (órgão pleno) ............................................... 102

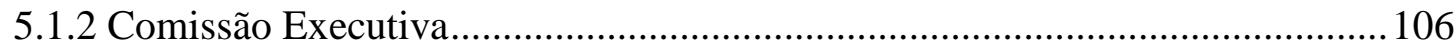

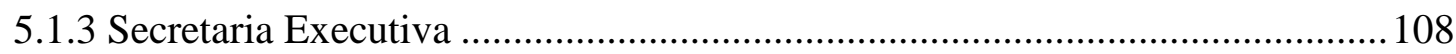

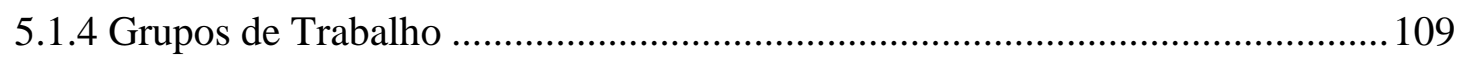

5.2 CONFLITO DE COMPETÊNCIAS ENTRE O CONSELHO E SUA COMISSÃO

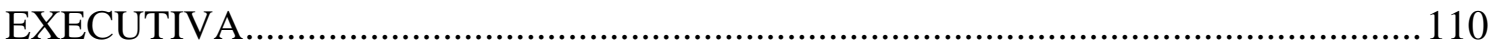

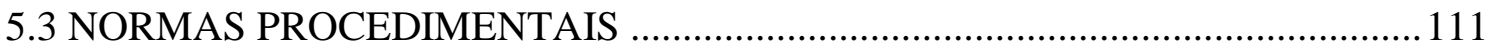

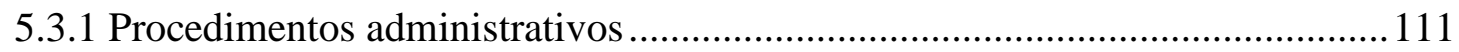

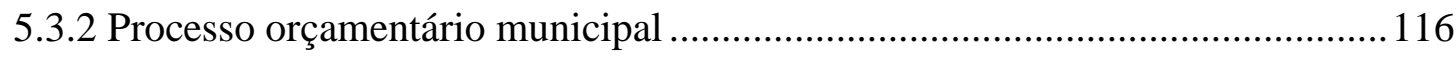

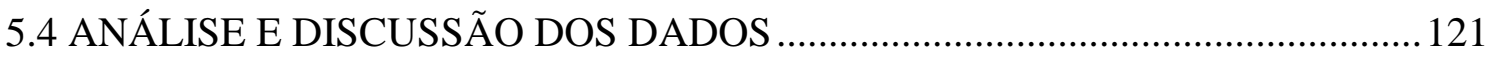

5.4.1 Participação do Conselho no processo orçamentário municipal ....................... 122

5.4.2 Aspectos instrutórios do procedimento administrativo ................................... 128

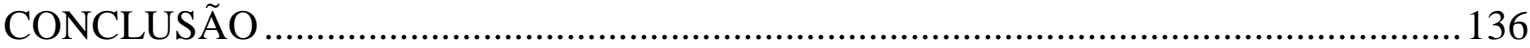


REFERÊNCIAS BIBLIOGRÁFICAS

APÊNDICE..

APÊNDICE A - Lista das atas de reunião analisadas. 


\section{INTRODUÇÃO}

A presente pesquisa se propõe a estudar o tema da procedimentalização ou processualidade da atividade administrativa nos Conselhos Municipais de Políticas Públicas e, mais especificamente, o regime jurídico dos procedimentos administrativos aplicáveis aos Conselhos e a participação dos Conselhos no processo orçamentário municipal de São Paulo, tendo como estudo de caso o Conselho Municipal de Habitação de São Paulo (CMH).

Por procedimentalização ou processualidade da atividade administrativa deve-se entender a necessidade de que as decisões administrativas surjam como conclusão de uma série ordenada de atos, estruturados entre si, de modo a propiciar: a) a participação de todos os interessados; b) a ampla investigação da realidade; c) a exposição dos motivos determinantes para as escolhas adotadas e; d) a submissão da decisão à revisão de entendimentos (JUSTEN FILHO, 2014).

A pertinência e indispensabilidade do procedimento administrativo no exercício do Poder estatal justificam-se, entre outras, pelas seguintes razões atuais: a) a insuficiência dos conceitos jurídicos indeterminados utilizados na lei para lidar com a imprevisibilidade das necessidades coletivas e a dificuldade de enquadrá-las no caso concreto a partir de simples silogismo; b) a atuação cada vez mais presente da própria Administração na elaboração das leis e atos normativos; c) a preocupação com a efetividade dos direitos sociais previstos na Constituição; d) a influência de um grande número de associações e entidades de pressão sobre a Administração visando interferir em suas decisões. Assim, o dogma da constituição da vontade unilateral do Estado abre espaço à consensualidade e à participação da sociedade na formação da vontade estatal (DUARTE, 1996; MEDAUAR, 2009; BANDEIRA DE MELLO, 2014).

No Brasil, os Conselhos Municipais de Políticas Públicas - como expressão da processualidade da atividade administrativa - foram gestados a partir da participação política dos movimentos sociais populares durante a transição democrática brasileira (GOHN, 1991; BOSCHI, 1987; SADER, 2001) em resposta ao passivo político, econômico e social decorrente do Projeto Nacional Desenvolvimentista (1972-1974) e do "milagre econômico" (1968 a 1973) promovidos pelo Regime Militar (1964-1985), somando-se à falta de apoio dos representantes eleitos às classes sociais mais pobres. Situação que as levou à autoorganização política em associações comunitárias para lutarem por melhores condições de 
vida nas áreas de saúde, moradia, saneamento básico, transporte público etc. (KOWARICK; BRANT, 1976; KOWARICK; CAMPANÁRIO, 1993; GOHN, 1991; DAGNINO, 2002; AVRITZER, 2000).

Os Conselhos Municipais de Políticas Públicas, tal como os conhecemos hoje, são órgãos públicos, colegiados, de composição mista - governo e sociedade civil, de caráter permanente e cujo feixe de atribuições, previsto em lei, envolve sua participação institucional na elaboração, consulta e/ou fiscalização de políticas públicas municipais (MOREIRA NETO, 1992; GOHN, 2011; PEREZ, 2004).

Dada a importância do planejamento orçamentário das políticas públicas, circunscrevemos o tema da procedimentalização nos Conselhos, primeiro, em torno do regime jurídico dos procedimentos administrativos aplicáveis aos Conselhos a fim de compreender a qualidade de seu processo decisório; segundo, analisaremos a participação dos Conselhos no processo orçamentário municipal de São Paulo. Como estudo de caso, escolhemos o Conselho Municipal de Habitação de São Paulo.

Para a adequada compreensão do tema, a seguir, apresentamos os caminhos a serem percorridos nesta pesquisa.

No primeiro capítulo, apresentaremos o desenho da presente pesquisa: sua problemática e delimitação do tema, seus objetivos, as questões que pretende responder e as hipóteses que busca verificar. Discorreremos ainda sobre o método do Estudo de Caso, exposto, principalmente, por Robert K. Yin (2010), e sobre a técnica da Análise de Conteúdo, apresentada, em grande parte, por Laurence Bardin (2009), os quais serão utilizados para analisar o caso do $\mathrm{CMH}$.

No segundo capítulo, buscamos contextualizar a experiência dos Conselhos Municipais de Políticas Públicas no modelo teórico de democracia participativa. Em seguida, apresentaremos os antecedentes históricos, sociais e políticos da institucionalização dos Conselhos na esfera político-administrativa dos municípios brasileiros. Então, descreveremos as características usualmente referidas pela doutrina acerca dos Conselhos Municipais de Políticas Públicas. Por fim, analisaremos as discussões doutrinárias sobre a atual problemática envolvendo os Conselhos e o $\mathrm{CMH}$, com destaque para os problemas que a presente pesquisa se propõe a analisar.

No terceiro capítulo, discutiremos o conceito de procedimentalização ou processualidade da atividade administrativa. Exporemos brevemente a discussão doutrinária sobre o uso do termo "procedimento administrativo" ou "processo administrativo" para se referir ao meio pelo qual os Conselhos desenvolvem suas atividades. Em seguida, 
analisaremos o regime jurídico dos procedimentos administrativos aplicáveis aos Conselhos Municipais de Políticas Públicas. Primeiro, abordando os princípios de processo administrativo e, depois, as etapas que compõem o procedimento administrativo. Nesse capítulo, objetiva-se estudar os direitos e as garantias processuais dos conselheiros nos procedimentos administrativos dos Conselhos.

No quarto capítulo, procuraremos compreender o sentido de política pública na perspectiva jurídica e o ciclo de formação das políticas públicas segundo a Ciência Política. Analisaremos também as políticas públicas segundo o direito financeiro, isto é, a partir do processo orçamentário. Primeiro, abordaremos os princípios orçamentários que regem a matéria. Em seguida, analisaremos os principais instrumentos de planejamento e orçamento previstos no direito vigente: o Plano Diretor Estratégico, o Programa de Metas e Leis orçamentárias (Plano Plurianual, Lei de Diretrizes Orçamentárias e Lei Orçamentária Anual). Aproximando-se do objeto de pesquisa, exploraremos as normas e os procedimentos de elaboração das peças orçamentárias no município de São Paulo, sob a perspectiva dos Conselhos Municipais de Políticas Públicas. Por fim, veremos o regime financeiro dos Fundos Especiais usados para o financiamento de políticas sociais, elaboradas pelos Conselhos.

No quinto capítulo, com base nos referenciais teóricos construídos nos capítulos precedentes, averiguaremos o desenho e dinâmica dos procedimentos administrativos do $\mathrm{CMH}$ de acordo com as garantias processuais dos conselheiros, bem como se, e de que modo, o CMH tem participado do processo orçamentário municipal de São Paulo de 2003 a 2015, e, em caso negativo, entender suas possíveis causas.

No último capítulo, exporemos as conclusões desta pesquisa e, em resumo, relaciona a problemática da pesquisa ao exercício de atribuições estranhas às competências legais do $\mathrm{CMH}$.

Por fim, o interesse pelo tema surgiu a partir de vivências do autor junto à conhecida “Ocupação Prestes Maia”, prédio localizado na Avenida Prestes Maia, centro de São Paulo. Esse prédio possui dívidas fiscais e encontra-se abandonado há décadas. Em decorrência do déficit habitacional da cidade, o prédio foi ocupado e passou a servir de residência a centenas de famílias de trabalhadores de baixa renda, representadas politicamente pelo Movimento dos Sem-Teto do Centro (MSTC) desde 2004 até a atualidade. A partir de 2005, o prédio ganhou atenção da mídia e de Coletivos de Arte, que lá instalaram exposições artísticas com vistas a chamar a atenção das autoridades públicas para o problema habitacional. Foi então que, em 2005, a convite de um desses artistas, Túlio Tavares, tive a oportunidade de conhecer 
aquela realidade, as pessoas que lá viviam e a atuação daquele movimento popular junto ao CMH. Sobre esse episódio há, inclusive, uma dissertação intitulada "Situação Prestes Maia: o processo de colaboração entre artistas, coletivos artísticos e o Movimento Sem-Teto do Centro (MSTC). Ocupação Prestes Maia/São Paulo (2003-2007)”, de autoria de Sebastião Oliveira Neto (2012).

O presente estudo espera contribuir para o aprimoramento dos procedimentos dos Conselhos e, especialmente, do CMH a fim de garantir a eficiência e efetividade deste instrumento de participação popular na formulação de políticas públicas sociais (BARNES, 2012; CASSESE, 2012). 


\section{DESENHO DA PESQUISA E METODOLOGIA}

\subsection{PROBLEMATIZAÇÃO E DELIMITAÇÃO DO TEMA DE PESQUISA}

A presente pesquisa se propõe a estudar o tema da procedimentalização ou processualidade da atividade administrativa nos Conselhos Municipais de Políticas Públicas e, mais especificamente, o regime jurídico dos procedimentos administrativos aplicáveis aos Conselhos e a participação dos Conselhos no processo orçamentário municipal de São Paulo, tendo como estudo de caso o $\mathrm{CMH}$.

Embora se trate de experiência participativa de, no mínimo, duas décadas, a literatura especializada aponta que os Conselhos Municipais de Políticas Públicas têm se destacado mais como instâncias de fiscalização que pela proposição de políticas públicas ou pela redefinição política dos gastos públicos (TATAGIBA, 2010). Este fato pode estar relacionado à constatação de que as atividades de planejamento e de orçamento são vividas pelos Conselhos ainda como "mundos distintos", daí decorrendo sua pouca influência na elaboração das peças orçamentárias - Plano Plurianual - PPA, Lei de Diretrizes Orçamentárias - LDO e Lei Orçamentária Anual - LOA no país (OLIVEIRA, 2014; BRASIL, 2011). Além disso, a literatura ressalta que, não raro, as deliberações dos Conselhos têm se desenvolvido sem o necessário esclarecimento e a adequada instrução processual das proposições (TATAGIBA, 2010; CARNEIRO, 2006).

Contudo, os Conselhos de Políticas Públicas "pouco podem fazer para influírem nas ações e decisões governamentais, caso suas atenções também não estejam direcionadas ao gerenciamento e à utilização dos recursos financeiros em posse da Administração Pública” (ASSONI FILHO, 2009, p. 89).

Por isso, dada a importância do planejamento orçamentário das políticas públicas, delimitamos o tema da procedimentalização nos Conselhos, primeiro, em torno do regime jurídico dos procedimentos administrativos aplicáveis aos Conselhos, a fim de compreender a qualidade do processo decisório; segundo, em relação à participação dos Conselhos no processo orçamentário municipal de São Paulo, a fim de averiguar a influência do colegiado na elaboração de políticas públicas. Como estudo de caso, escolhemos o Conselho Municipal de Habitação de São Paulo. 


\subsection{OBJETIVOS E QUESTÕES DA PESQUISA}

Os objetivos gerais deste estudo são:

1) Analisar o regime jurídico dos procedimentos administrativos aplicáveis aos Conselhos.

2) Analisar a participação dos Conselhos no processo orçamentário municipal de São Paulo.

Os objetivos específicos desta pesquisa são:

1) Verificar a adequação dos procedimentos administrativos que regem o CMH ao regime jurídico dos procedimentos administrativos aplicáveis aos Conselhos de 2003 a 2015.

2) Analisar a participação do CMH no processo orçamentário municipal de São Paulo de 2003 a 2015.

Uma vez definidos os objetivos, as questões que o estudo procura responder são:

1) Que regras procedimentais deveriam ser observadas no âmbito dos Conselhos em geral?

2) De que maneira os Conselhos deveriam participar do processo orçamentário municipal de São Paulo?

3) Os conselheiros têm exercido adequadamente os direitos ao contraditório e a ampla defesa nos procedimentos administrativos do CMH? Em caso de participação procedimental deficiente, quais seriam as possíveis causas?

4) Como tem se desenvolvido a participação do CMH no processo orçamentário municipal de São Paulo? Em caso de participação inexistente ou deficiente, quais seriam as possíveis causas? 
A partir do referencial teórico e da preliminar coleta de dados, levantamos as seguintes hipóteses de pesquisa:

1) Os procedimentos administrativos do CMH são inadequados, imprecisos e ineficientes.

2) A participação do CMH não tem sido efetiva no processo orçamentário municipal de São Paulo.

\subsection{MÉTODO DE PESQUISA: ESTUDO DE CASO}

Diante das diferenças e das especificidades entre os diversos Conselhos Municipais de Políticas Públicas e com o objetivo de apreender em profundidade a realidade vivida, optamos por um estudo de natureza qualitativa e, por isso, o Estudo de Caso mostrou-se o método de pesquisa mais apropriado.

É relevante notar que, na pesquisa qualitativa, busca-se por respostas para questões particulares. Ou seja, esse tipo de pesquisa "trabalha com o universo de significados, motivos, aspirações, crenças, valores, atitudes, o que corresponde a um espaço mais profundo das relações, dos processos e dos fenômenos que não podem ser reduzidos à operacionalização de variáveis” (MINAYO, 1992, p. 22).

Para Menga, o estudo qualitativo "é o que se desenvolve numa situação natural; é rico em dados descritivos, tem um plano aberto e flexível e focaliza a realidade de forma complexa e contextualizada" (apud, MARCONI; LAKATOS, 2007, p. 271). Maria de Andrade Marconi e Eva Maria Lakatos complementam que, "por meio do método qualitativo, o pesquisador entra em contato direto e prolongado com o indivíduo ou grupos humanos, com o ambiente e a situação que está sendo investigada, permitindo um contato de perto com os informantes" (MARCONI; LAKATOS, 2007, p. 272) a exemplo do contato direto que tivemos com os membros do $\mathrm{CMH}$ e os funcionários da Prefeitura Municipal de São Paulo. Outra característica do método qualitativo é a possibilidade de empregar diversos métodos e técnicas, dependendo do tipo de investigação.

Os estudos de caso, segundo Robert Yin, são relevantes para responder questões sobre "como" e "por que" algum fenômeno social funciona. Ou melhor, essa técnica é 
relevante quando as questões envolvidas exigirem uma descrição ampla e "profunda" de algum fenômeno social. Portanto, o Estudo de Caso pode ser caracterizado como "uma investigação empírica que investiga um fenômeno contemporâneo em profundidade e em seu contexto de vida real, especialmente quando os limites entre o fenômeno e o contexto não são claramente evidentes" (YIN, 2010, p. 39).

Segundo Roberto Sidnei Macedo (2000), os estudos de caso visam à descoberta, característica que se fundamenta no pressuposto de que o conhecimento não é algo acabado, e sim algo que se constrói, se faz e refaz constantemente.

\begin{abstract}
Assim, o estudo de caso tem por preocupação principal compreender uma instância singular, especial. O objeto estudado é tratado como único, ideográfico (especial, singular) mesmo compreendendo-o numa totalidade composta de, e que compõe outros âmbitos ou realidades. Desse modo, a questão sobre o caso ser ou não típico, isto é, empiricamente representativo de uma população determinada, torna-se inadequado; o objeto não é recortado por uma amostragem com preocupações nomotéticas, já que cada caso é tratado como tendo um valor próprio. Além disso, em face da inerente flexibilidade dos estudos pontuais, da abertura que cultiva face ao inusitado, os casos estudados vão constituir teorias em ato, impregnadas dos aspectos inerentes à temporalidade da emergência complexa das "realidades vivas" (MACEDO, 2000, p. 150, destaque ausente no original).
\end{abstract}

O Estudo de Caso, segundo Marconi e Lakatos (2007), envolve ainda um levantamento com mais profundidade de determinado caso ou grupo humano sob todos os seus aspectos. Além disso, abrange algumas características fundamentais, a saber: visa à descoberta; enfatiza a interpretação do contexto; retrata a realidade de forma mais ampla; vale-se de diversas fontes de informação; permite substituições; representa diferentes pontos de vista em determinada situação; e, por fim, permite o uso de uma linguagem simples.

Considerando-se, portanto, a natureza qualitativa desta pesquisa e os seus objetivos, a utilização do Estudo de Caso como método de pesquisa mostrou-se profícua, na medida em que esta técnica, segundo Gabriela de Brelàz (2012), é amplamente utilizada para as investigações sobre a participação da sociedade civil, como é o caso dos Conselhos Municipais de Políticas Públicas.

O estudo de apenas um caso - o Conselho Municipal de Habitação de São Paulo, justifica-se teoricamente pelo interesse de analisar a evolução de seus procedimentos administrativos e de sua participação no processo orçamentário entre 2003 a 2015. Trata-se, então, de um Estudo de Caso longitudinal, no qual se objetiva o estudo de um caso único em pontos diferentes do tempo, verificando como determinadas condições mudam no tempo, e, 
para este fim, revela-se apropriado o estudo de um caso único (YIN, 2010).

Após a escolha do Estudo de Caso longitudinal como método de pesquisa, o presente estudo buscou técnicas necessárias para a coleta e a análise dos dados. Neste trabalho, optou-se pela utilização da pesquisa documental (especialmente a análise das atas coletadas nas diversas gestões do $\mathrm{CMH}$ ), combinada com a técnica de Análise de Conteúdo.

\subsection{TÉCNICA DE COLETA E ANÁLISE DE DADOS}

\subsubsection{Pesquisa Documental}

A Pesquisa Documental caracteriza-se pelo levantamento de documentos em um sentido amplo, ou seja, não somente documentos impressos, mas, sobretudo, outros tipos de documentos, tais como: jornais, gravações, documentos legais. Nesses casos, portanto, o conteúdo dos textos são a matéria-prima a partir da qual o pesquisador desenvolverá sua investigação e análise (SEVERINO, 2007).

Para Gilberto Martins (2008), a Pesquisa Documental é relevante em um estudo de caso, na medida em que propicia melhor entendimento do caso e também corrobora evidências coletadas por outros instrumentos e outras fontes, possibilitando a confiabilidade de achados a partir da triangulação de dados e resultados.

A Pesquisa Documental desta pesquisa se refere às atas de reunião do órgão pleno do CMH e de sua Comissão Executiva de 2003 a 2015, totalizando 95 atas de reunião, das quais apenas duas não foram localizadas ${ }^{1}$.

Nos termos do artigo 13 do Regimento Interno do CMH (SÃO PAULO, 2003), as atas de reunião do órgão pleno do $\mathrm{CMH}$ e de sua Comissão Executiva, após aprovação, devem ser publicadas no Diário Oficial do Município de São Paulo (DOCSP). Até janeiro de 2005, obtivemos as atas de reunião no portal eletrônico do Diário Oficial do Estado de São Paulo <www.imprensaoficial.com.br/>, onde também consta o acerco do DOCSP. A partir de então, as atas de reunião foram obtidas diretamente no portal eletrônico do DOCSP <www.docidadesp.imprensaoficial.com.br>.

\footnotetext{
${ }^{1}$ Cf. Apêndice A - Lista das atas de reunião analisadas.
} 
Nestes portais, não conseguimos encontrar todas as 95 atas de reunião. Nestes casos, procedemos à pesquisa pessoal junto à Secretaria Executiva do $\mathrm{CMH}^{2}$, cujos funcionários nos disponibilizaram diversas atas relativas à $1^{\text {a }}$ Gestão (2003 a 2005) em formato digital ".doc" (Microsoft Word) ${ }^{3}$. Naquela repartição, fomos informados de que nem todas as atas foram publicadas no DOCSP e que algumas delas foram extraviadas pela Administração Municipal durante mudanças de local. Em que pese o exposto, como dito, apenas duas de todas as atas de reuniões não foram localizadas por esta pesquisa.

\subsubsection{Análise de Conteúdo}

A fim de proceder à análise das atas de reunião do $\mathrm{CMH}$, foi utilizado o método de Análise de Conteúdo, tendo em vista que essa técnica, segundo Martins (2008), é muito utilizada em conjunto com a Pesquisa Documental quando o objetivo é analisar e avaliar dados presentes em documentos, atas de reunião, estatutos, jornais internos, circulares, material escrito divulgado em site institucional de uma organização ou em textos de modo geral.

Além disso, a Análise de Conteúdo é utilizada quando se busca, entre outros aspectos: descrever tendências no contexto das comunicações; comparar mensagens, níveis e meios de comunicação; identificar intenções, características e apelos de comunicadores; bem como desvendar as ideologias dos dispositivos legais (MARTINS, 2008).

Para Bardin, o método de Análise de Conteúdo é, sobretudo, um “conjunto de técnicas de análise das comunicações visando obter, por procedimentos sistemáticos e objectivos de descrição do conteúdo das mensagens, indicadores (quantitativos ou não) que permitam a inferência de conhecimentos relativos às condições de produção/recepção (variáveis inferidas) destas mensagens" (BARDIN, 2009, p. 44).

Ainda no campo da Análise de Conteúdo, algumas técnicas, segundo Maria Cecília de Souza Minayo (1992), auxiliam na busca pelos significados manifestos e latentes no material qualitativo. Segundo a autora, uma das possibilidades proporcionadas pela Análise

\footnotetext{
${ }^{2}$ Secretaria Executiva do CMH, sediada na Secretaria Municipal de Habitação e Desenvolvimento Social de São Paulo - SEHAB, Edifício Martinelli, localizado na Rua São Bento, 405, $10^{\circ}$ Andar, Centro, São Paulo-SP. ${ }^{3}$ Cf. ANEXO A - Atas de reunião não localizadas no DOCSP, mas disponibilizadas pela Secretaria Executiva do CMH em formato ".doc" (Microsoft Word) a esta pesquisa.
} 
de Conteúdo é a Análise Temática, comumente utilizada para descobrir os núcleos de sentido que compõem a comunicação e cuja presença ou frequência de aparição tem significado para o objetivo analítico visado. Para Bardin, o tema pode ser caracterizado como uma "unidade de significação que se liberta naturalmente de um texto analisado segundo certos critérios relativos à teoria que serve de guia à leitura" (BARDIN, 2009, p. 131).

Neste estudo, optou-se, portanto, por realizar uma Análise Temática dos dados colhidos nas atas do $\mathrm{CMH}$. Do ponto de vista operacional, seguimos as etapas da Análise Temática propostas por Minayo (1992) e Martins (2008), tais como são descritas a seguir:

1) Pré-análise (coleta e organização do material a ser analisado): realizou-se a leitura flutuante das atas, nas cinco gestões do CMH, do período de 2003 a 2015.

2) Exploração do material (estudo aprofundado do material, orientado pelas hipóteses e pelo referencial teórico, e escolha das unidades de significação de análise - a palavra, o tema etc.): após a leitura flutuante dos documentos, buscou-se a operação de codificação, momento em que se realiza a transformação dos dados brutos visando alcançar o núcleo de compreensão do texto. Após esse recorte, as unidades de significação foram sistematizadas em categorias ou temas, distribuídas em:

a) Participação do Conselho no processo orçamentário municipal, a partir da qual procuramos selecionar e analisar os debates envolvendo a participação do Conselho na discussão, elaboração e aprovação das diversas peças orçamentárias (PPA, LDO e LOA) em confronto com o referencial teórico analisado no capítulo 4.

b) Aspectos instrutórios do procedimento administrativo, a partir da qual procuramos selecionar e analisar os debates envolvendo as fases de instrução do procedimento administrativo interno do Conselho em confronto com o referencial teórico analisado no capítulo 3.

3) Tratamento dos resultados obtidos e interpretação: ao considerar a natureza qualitativa deste estudo, optou-se por trabalhar com os significados no tratamento dos resultados obtidos, em lugar de inferências estatísticas (modelo quantitativo). Dessa forma, procedeu-se à análise temática das categorias supracitadas a partir das evidências coletadas 
nas atas de reunião, notadamente, as manifestações espontâneas e voluntárias dos conselheiros sobre os assuntos em debate, para se chegar às conclusões desta pesquisa.

No próximo capítulo, buscaremos contextualizar a experiência dos Conselhos Municipais de Políticas Públicas no modelo teórico de democracia participativa. Em seguida, apresentamos os antecedentes históricos, sociais e políticos da institucionalização dos Conselhos na esfera político-administrativa dos municípios brasileiros. Depois, descrevemos sobre as características mais usualmente referidas pela doutrina acerca dos Conselhos Municipais de Políticas Públicas. Por fim, apresentaremos as discussões doutrinárias sobre a atual problemática envolvendo os Conselhos e o $\mathrm{CMH}$, com destaque para os problemas que a presente pesquisa se propõe a analisar. 


\section{CONSELHOS MUNICIPAIS DE POLÍTICAS PÚBLICAS}

\subsection{A DEMOCRACIA PARTICIPATIVA NA ATUALIDADE}

Ainda que a constituição dos Conselhos Municipais de Políticas Públicas não tenha recebido contribuições teóricas prévias (e isso será abordado mais à frente), podemos dizer que eles, Conselhos, assemelham-se ao modelo teórico da democracia participativa, segundo a qual, na atualidade, o Estado encontra-se envolvido por uma miríade de atores públicos e privados que exercem forte influência no ciclo de formação das políticas públicas.

Segundo Miguel Sánchez Móron, na sociedade atual, a interdependência entre o público e o privado reduz os limites entre as esferas públicas e privadas. O poder estaria então distribuído desigualmente entre as diversas organizações sociais, de caráter público ou privado, e que se relacionariam de maneira constante e diversa com o Estado. Estas organizações seriam as grandes empresas e holdings, os grandes partidos, os sindicatos, as grandes Administrações Públicas etc. (SÁNCHEZ MÓRON, 1980).

Jünger Habermas (2014) entende que, na sociedade contemporânea, os interesses políticos nasceriam a partir de um processo de negociação e mediação de conflitos entre o Estado e a sociedade. E isso se daria de tal forma que a expansão da autoridade pública sobre o âmbito privado estaria associada também ao movimento inverso de substituição do poder estatal pelo poder social, diluindo os limites entre o público e o privado.

No mesmo sentido, ao descrever o que chama de Estado policêntrico, Jaques Chevallier (2009) acentua que a Administração Pública aparece, atualmente, envolvida pela diversidade, fluidez e indeterminação e, por essa razão, a ação administrativa surgiria como o resultado de um complexo sistema de interações entre os segmentos do Estado e os interesses privados.

Celina Souza julga que o Estado, por um lado, não se vê preso ao jogo de pressões dos diversos grupos de interesse, por outro, não mais define as políticas unilateralmente. $\mathrm{Na}$ linha intermediária, a autora considera que "existe uma 'autonomia relativa do Estado', o que faz com que tenha um espaço próprio de atuação, embora permeável a influências externas e internas" (SOUZA, 2006, p. 25-26).

Daí surge a noção de governança pública em que a identificação dos problemas 
públicos, das soluções e dos meios de implementação das decisões administrativas exigem a coordenação de múltiplos níveis e múltiplos atores públicos e privados em mecanismos de responsabilização e de legitimação para além do momento de eleição dos representantes (MASSA-ARZABE, 2006).

Tais mecanismos correspondem ao que Guillermo O'Donnell (1998) chama de accountability horizontal e Catalina Smulovitz e Enrique Peruzzotti (2003) chamam de accountability societal.

Para O'Donnell (1998), accountability horizontal corresponderia aos sistemas de controles recíprocos entre os Poderes Públicos, Executivo, Legislativo e Judiciário, acrescido do controle desempenhado por outros órgãos estatais investidos de funções de supervisão, fiscalização e controle.

Por sua vez, accountability societal envolveria a participação social em canais institucionalizados ou não institucionalizados. No primeiro caso, a participação visaria à defesa de direitos perante agências estatais ou à participação em procedimentos de formulação e de controle de políticas públicas (ex.: Conselhos de Políticas Públicas). No segundo caso, os grupos valem-se de mobilizações, protestos e denúncias públicas de caráter informal (SMULOVITZ; PERUZZOTII, 2003).

Nesse contexto, o Estado atuaria principalmente como árbitro ou mediador dos conflitos existentes na sociedade, conforme ressalta Gustavo Justino de Oliveira:

\begin{abstract}
A função estatal de mediação emana da propagação do ideal democrático para além do quadrante da política, resultado da busca do alargamento das bases de legitimação do exercício do poder estatal por meio da democratização da democracia. Incumbências do Estado mediador passam a ser não somente as de estabelecer e de conferir eficácia aos canais de participação e de interlocução com os indivíduos e grupos sociais, mas a de com eles constantemente interagir. [...] Ademais disso, cabe notar que a principal tarefa da Administração mediadora passa a ser a de compor conflitos envolvendo interesses estatais e interesses privados, definitivamente incluindo os cidadãos no processo de determinação $e$ densificação do interesse público (OLIVEIRA, 2010, p. 212-213, destaque nosso).
\end{abstract}

A referência feita pelo autor à "democratização da democracia" refere-se à introdução da chamada democracia participativa ao modelo de democracia clássico (democracia representativa), não para substitui-lo, mas para que o Estado receba influxos (inputs) da sociedade e submeta-se ao controle social de forma permanente.

Essa governança pública, no entanto, deve ser ordenada juridicamente, a fim de 
que o Estado-Administração não selecione seus interlocutores arbitrariamente, como observa Miguel Sánchez Morón:

\begin{abstract}
A magnitude dos grupos de pressão e o intervencionismo estatal acentuam a tendência para uma Administração aberta em contato com ditos grupos. A realidade do procedimento de formação do grande número de atos administrativos, quiçá os mais importantes socialmente, obedece a estas características. Agora bem, este modo de atuação administrativa está escassamente regulado juridicamente, pelo que cada autoridade goza de uma grande liberdade para eleger seus interlocutores, com evidente menoscabo da igualdade substancial e formal (SÁNCHEZ MORÓN, 1980, p. 171, tradução e destaque nosso).
\end{abstract}

Nesse sentido, o direito tem um papel fundamental na regulamentação dos mecanismos de controle e governança pública ao penetrar a política e a Administração Pública com o espírito ético do direito (GRAU, 1978).

No Brasil, essas novas funções de mediação, de abertura da Administração e de maior proximidade entre Estado-sociedade, refletem-se na atual configuração da Constituição Federal de 1988, artigo $1^{\circ}$, segundo a qual o Brasil se constitui em um Estado Democrático de Direito, com os objetivos de fundar uma sociedade livre justa e solidária $\left(\operatorname{art.} 3^{\circ}, I\right)$, baseando-se na soberania popular exercida por representantes eleitos (art. $1^{\circ}$, parágrafo único) ou diretamente na forma da lei $^{4}$ (AFONSO DA SILVA, 2014).

A Constituição Portuguesa de 1976, art. $2^{\circ}$, foi mais enfática ao prever entre os objetivos da República de Portugal, a realização da democracia econômica, social e cultural e o aprofundamento da democracia participativa. Comentando o dispositivo citado, Joaquim Gomes Canotilho ressalta que "o princípio democrático implica a estruturação de processos que ofereçam aos cidadãos efectivas possibilidades de aprender a democracia, participar nos processos de decisão, exercer controlo crítico na divergência de opiniões e produzir inputs políticos democráticos” (CANOTILHO, 1993, p. 415-416).

Na condição de um modo de reformulação do agir público, a chamada democracia participativa postula a inclusão de atores, antes, excluídos do debate social e econômico, bem como ilumina aquela arena de negociação e mediação público-privada tornando-a transparente e acessível ao controle social e dos demais órgãos estatais (CANOTILHO, 1993).

David Duarte considera que é relativamente pacífico, na atualidade, a ideia de que

${ }^{4} \mathrm{CF}$, artigos 10; 14, I a III; 29, XII e XIII; 31, §3º ; 49, XV; 61, §2 $; 198$, III; 204, II. 
a democracia participativa não visa superar ou substituir o modelo de democracia representativa, mas amenizar o déficit da representação autorizada e controlada politicamente apenas no momento eleitoral (DUARTE, 1996).

Sônia Fleury, no entanto, adverte que as críticas em relação à democracia participativa continuam a se basear na ideia de que ela restringiria a existência do regime democrático "ao solapar a legitimidade dos representantes eleitos, além de ser passível de manipulação da população pelo governante, fortalecendo, assim, sua autoridade em situações de conflito com o Legislativo" (FLEURY, 2006, p. 96).

Ao contrário do exposto por Sônia Fleury, entendemos que os instrumentos de democracia participativa atuam, exclusivamente, nos limites previstos em norma (lei, decreto etc.) de iniciativa privativa de cada um dos Poderes - Legislativo, Executivo ou Judiciário, não surtindo efeito jurídico em relação aos demais. Portanto, não se sustenta a afirmação de que a democracia participativa solaparia atribuições dos representantes eleitos ou que colocaria em risco competências exclusivas de cada um dos Poderes.

Além disso, segundo Leonardo Avritzer (2007), diferentemente do que ocorre nos mandatos eletivos e representativos tradicionais, não é a forma de autorização que justificaria a legitimidade da representação política da sociedade civil, mas a afinidade ou a identidade dos representantes com o setor social ao qual pertencem.

$\mathrm{O}$ argumento da legitimidade por "afinidade-identidade" se justifica quando os papeis de representante e representado estão conjugados na mesma pessoa, isto é: mulheres representando mulheres, negros representando negros, sem-tetos representando sem-tetos e assim por diante. A fim de construir seu argumento, os autores diferenciam os eventuais beneficiários (sociedade em geral ou até entidade representada) daquele que atua como representante dos interesses gerais e, ao mesmo tempo, como militante-participante (LAVALLE; HOUTZAGER; CASTELLO, 2006).

Luciana Tatagiba (2010) observa que a legitimidade da representação da sociedade civil é tema cada vez mais presente nos debates da literatura, demonstrando que não há consensos ou soluções unívocas para a questão. A autora aponta como tendência nos Conselhos a combinação entre diferentes formas de representação: "a representação por categorias e/ou por segmentos, junto com a representação territorial. A escolha dos representantes por suas próprias entidades, ao lado de formas de escolha que passam pelo voto dos moradores em pessoas indicadas por movimentos e/ou organizações”, por exemplo. Por fim, critica a apresentação de fórmulas "consagradas" que enrijeçam a experiência participativa e legitimem critérios meramente formais de participação. 
De qualquer modo, por se tratar de exercício de parcela da soberania popular, importante destacar que os instrumentos de participação também devem se submeter a constantes e permanentes mecanismos de sanção, controle e prestação de contas à população em geral (MIGUEL, 2003; LAVALLE; HOUTZAGER; CASTELLO, 2006).

Os fundamentos que justificam a participação popular na Administração Pública têm a ver com a abertura do Estado às influências da sociedade, sobretudo empresas privadas. Portanto, plenamente justificada a inclusão de outros atores sociais - movimentos populares, ONGs, universidades etc. - na "arena de negociação e mediação públicoprivada”. Como se viu, a democracia participativa não visa, nem tem a capacidade de interferir, juridicamente, no exercício do mandato dos representantes eleitos.

A seguir, considerando a existência de polissêmicos sentidos para o termo "participação" ou "participação administrativa", apresentaremos, no tópico seguinte, o conceito que se adequa aos objetivos deste trabalho.

\subsection{PARTICIPAÇÃO ADMINISTRATIVA}

Dentre os vários e polissêmicos sentidos dados usualmente à participação na atividade administrativa, citamos três formas diferentes: a) a participação de particulares nos processos administrativos para a defesa de direitos e interesses individuais; b) a participação de particulares na prestação de serviços públicos e; c) a participação da sociedade civil nos processos administrativos envolvendo interesses difusos ou transindividuais ${ }^{5}$.

Como se vê, o conceito de participação carece de um tratamento jurídico mais adequado, uma vez que tem sido utilizado para promover distintas formas de exercício do

\footnotetext{
5 Adotamos, no presente trabalho, o conceito de interesses difusos exposto por Hugo Nigro Mazzilli, para quem: "Difusos - como os conceitua o CDC - são interesses ou direitos 'transindividuais, de natureza indivisível, de que sejam titulares pessoas indeterminadas e ligadas por circunstâncias de fato'. Os interesses difusos compreendem grupos menos determinados de pessoas (melhor do que pessoas indeterminadas, são antes pessoas indetermináveis, entre as quais inexiste um vínculo jurídico ou fático preciso. [...] Advirta-se, porém, que, embora o CDC se refira a ser uma situação fática o elo comum entre os lesados que compartilhem o mesmo interesse difuso, é evidente que essa relação fática também se subordina a uma relação jurídica (como, de resto, ocorre com quaisquer relações fáticas e jurídicas); entretanto, no caso dos interesses difusos, a lesão ao grupo não decorrerá diretamente da relação jurídica em si, mas sim da situação fática resultante. Assim, p. ex., um dano ambiental que ocorra numa região envolve tanto uma situação fática comum como uma relação jurídica incidente sobre a hipótese; mas o grupo lesado compreende apenas os moradores da região atingida - e, no caso, este será o elo fático que caracterizará o interesse difuso do grupo" (MAZZILLI, 2008, p. 53).
} 
poder, como já foram e ainda são utilizadas as expressões "interesse geral", "Estado Social" entre outros. Certo é que o princípio da participação popular não deve ser confundido com a participação do particular no processo administrativo para defesa de interesse individual (SÁNCHEZ MORÓN, 1984). A mesma crítica é feita por David Duarte, segundo o qual a utilização da expressão participação "de forma polissêmica, propicia uma multiplicidade de leituras e de realidades diferenciadas, prejudicando a apreensão do seu conteúdo conceptual” (DUARTE, 1996, p. 109).

Por isso, neste trabalho, não nos referimos à participação administrativa uti singuli do cidadão como parte de um processo administrativo, para a defesa de interesses individuais. Fazemos menção à participação administrativa relativa aos interesses uti socius, uti cives, ou seja, na consecução de interesses difusos por meio de políticas públicas sociais de saúde, educação, moradia, saneamento básico etc. (GARCIA DE ENTERRÍA; FERNÁNDEZ, 1998).

Uma das maiores vantagens da participação administrativa (ou participação procedimental) seria a canalização e tratamento, juridicamente ordenado, dos conflitos e demandas sociais, o que, ao contrário das críticas levantadas acima à democracia participativa, amenizaria o risco de ruptura dos laços democráticos e das instituições representativas (MOREIRA NETO, 2014; LUHMANN, 1980).

A participação administrativa tem evidente caráter pedagógico e de composição dos conflitos, diferenciando-se de práticas clientelistas ${ }^{6}$ e patrimonialistas ${ }^{7}$ arraigadas na cultura brasileira. Ao revés, inaugura um sentimento de emancipação política do cidadão, o qual apreende que não depende de tal ou qual político, vereador ou cabo eleitoral para receber um direito social que já lhe é garantido pela Constituição Federal.

Em síntese, Gustavo Justino de Oleira (2010) enfatiza que "a participação popular na Administração Pública - ou participação administrativa - é considerada um dos principais meios para tornar efetiva a democracia administrativa" (p. 21-22), ou seja, para que se viabilize, "através de mecanismos institucionais, a efetivação de direitos, não somente individuais, mas sociais, coletivos e difusos" (p. 17).

A seguir, analisaremos o contexto social e político que propiciaram a idealização,

\footnotetext{
${ }^{6}$ Relativo a "clientelismo". Pela expressão se pode entender todo tipo de relação de troca de apoio político (consenso eleitoral) ou material (financeiro) dependente de "ajuda" pública, legítima ou não (direitos sociais, cargos, empregos públicos, financiamentos, autorizações etc.), gerando uma relação de dependência econômica ou política entre as partes (BOBBIO; MATTEUCCI, PASQUINO, 1998, pp. 177-179).

7 "Tipo de organização política em que as relações subordinativas determinam-se pela dependência econômica e pelo sentimento de lealdade e respeito entre governantes e governados". (DINIZ, 1998, p. 541).
} 
construção e consolidação dos Conselhos Municipais de Políticas Públicas na esfera políticoadministrativa dos municípios brasileiros.

\subsection{PARTICIPAÇÃO POPULAR NA TRANSIÇÃO DEMOCRÁTICA: A ORIGEM DOS CONSELHOS MUNICIPAIS DE POLÍTICAS PÚBLICAS}

No Brasil, os chamados Conselhos Municipais de Políticas Públicas ${ }^{8}$ foram gestados pela sociedade civil em resposta às crises política, econômica e social acumuladas durante o regime militar (1964-1985), até se constituírem como órgãos públicos na forma prevista pela Constituição Federal de 1988, com presença marcante na atual organização político-administrativa brasileira.

Antes de tratar das experiências de organização da sociedade civil na transição democrática, convém resgatar as condições objetivas e subjetivas que às impulsionaram.

Após a Segunda Guerra Mundial, verifica-se uma nova tendência da economia mundial: a internacionalização do parque industrial dos países europeus e dos Estados Unidos em direção aos países periféricos, entre eles o Brasil. Estes países ganharam importância como centros de acumulação do capital multinacional, ficando conhecidos como os novos países industrializados ou NICS (New industrialized countries), porém, extremamente dependentes das flutuações do capitalismo central (KOWARICK; CAMPANÁRIO, 1993).

Alinhando-se a esse processo de redistribuição regional dos meios produtivos internacionais, os militares dão impulso ao projeto nacional-desenvolvimentista por meio do I Plano Nacional de Desenvolvimento (1972-1974), que implementou a política de substituição das importações, estímulo ao consumo de produtos nacionais, farta concessão de benefícios fiscais, controle de preços e mecanismos de indexação da economia. Porém essa política foi efetivada à custa do aumento da dívida pública, da inflação e do déficit social, como se verá a seguir (LISBOA; LATIF, 2013).

Como parte desse projeto desenvolvimentista, houve o deslocamento de boa parte da população brasileira que vivia no campo para o novo parque industrial instalado nos

\footnotetext{
${ }^{8}$ Não devem ser confundidos com os chamados Conselhos Nacionais de Políticas Públicas, os quais tiveram outras causas e que não serão objeto desta pesquisa. Aqui, iremos nos ater aos Conselhos de Políticas Públicas em nível local.
} 
centros urbanos. Em 1960, 55\% da população brasileira vivia em cidades, já em 1989 essa porcentagem aumentou para 67\%. No período entre 1960 e 1989, o país registrou uma média de crescimento anual do PIB de 6\%, comparável ao crescimento do Japão $(6,8 \%)$ e da Coréia $(7,7 \%)$, superior inclusive aos EUA $(3,2 \%)$ e a Alemanha $(3,6 \%)$, chegando ao ápice de 11,2\% no período de 1968-1973, período que ficou conhecido como "milagre econômico" brasileiro (AGGIO, 1996).

No entanto, este "milagre econômico" (1968 a 1973), fortemente dependente da economia mundial, logo se mostrou efêmero diante da crise dos preços do petróleo (1973 e 1979) e do aumento da dívida externa bruta, que saltou de US\$ 12 bilhões para US\$ 64 bilhões entre 1973 e 1980, consumindo nossas reservas financeiras para o pagamento dos juros da dívida (SANTAGADA, 1990).

Paralelamente ao desenvolvimento econômico mencionado, o país acompanhou a deterioração das condições de vida nas metrópoles. Em cidades como São Paulo, o "subdesenvolvimento industrializado" evidenciará suas maiores contradições. Ao mesmo tempo em que os trabalhadores rurais perdiam seus empregos para a mecanização do campo, o fluxo migratório chegava a cidades carentes de serviços urbanos básicos - v.g. transporte, água, esgoto, habitação. Agravando a situação, o salário mínimo real do trabalhador sofreu desvalorização na ordem de 60\% entre 1959 e 1991, tanto que a porcentagem de famílias pobres no Brasil chega a 42,1\% em 1987 (KOWARICK; BRANT, 1976; KOWARICK; CAMPANÁRIO, 1993).

Diante dessas informações, é possível concluir que o crescimento econômico observado entre 1960 e 1989 na ordem de 6\% ao ano, não representou distribuição de renda, já que a população brasileira teve seu salário mínimo defasado em $60 \%$ no mesmo período. E, pior, representou a precarização das cidades, na medida em que seu crescimento, com ausência de políticas públicas sociais, agravou as condições de saneamento, transporte, saúde, educação e habitação para as faixas mais pobres da população.

Como até então grande parte dos partidos políticos estavam na clandestinidade ou comprometidos com a implementação do "subdesenvolvimento industrializado", não restou à população em vulnerabilidade social outro caminho senão a auto-organização a fim de representar seus interesses perante o Estado (GOHN, 1991).

Estabelecendo-se como os únicos núcleos de organização possíveis durante a ditadura militar, os movimentos sociais populares passaram a ganhar cada vez mais adeptos e simpatizantes entre os sindicatos, associações profissionais, universidades, igrejas, imprensa, partidos políticos, etc. (DAGNINO, 2002). Cabe também registrar o importante 
papel desempenhado pelos centros de assessoria aos movimentos sociais: profissionais autônomos ou instituições como a Igreja Católica, partidos clandestinos, grupos de esquerda, universidades etc., prestavam assessoria técnica e material aos movimentos sociais nos anos 1970 e $1980\left(\mathrm{ONGs}^{9}\right)$ (TEIXEIRA, 2003).

Estas organizações de apoio serviram para conectar movimentos sociais, entidades governamentais, partidos políticos, mídia, igreja, setores de ONGs internacionais, entre outros, formando uma rede de apoio mútuo culturalmente democrática.

O exemplo da falta de apoio dos representantes eleitos e o caminho de autorepresentação popular pode ser observado no caso de uma associação comunitária na favela do Vidigal, cidade do Rio de Janeiro, organizada em um contexto de remoção e reassentamento de famílias de suas residências. Vejamos:

Os moradores que aceitaram a oferta de reassentamento rapidamente perceberam que seu novo bairro era deficiente em todos os serviços básicos e distantes do centro da cidade. Os moradores remanescentes da favela do Vidigal se organizaram e buscaram a liderança política local, que era o agente político representante dos interesses da região. Entretanto, o político se esquivou quando a comunidade necessitou levar sua demanda ao Estado e às autoridades governamentais. A incapacidade desse grupo de encontrar uma representação política adequada levou à ativação de uma associação comunitária. Subsequentemente, os ativistas do Vidigal buscaram criar uma organização política e social autônoma que não estivesse vinculada aos interesses políticos tradicionais (AVRITZER; WAMPLER, 2004, p. 217).

O caso da favela do Vidigal é muito representativo quanto: a) ao surgimento de consciência das classes populares "para si”; b) à carência de sua representação política nas elites políticas em relação às classes populares de baixa renda e; c) ao início da representação autônoma da sociedade civil em relação às instituições representativas tradicionais.

Evidenciando o recrudescimento do associativismo no país, entre 1961 e 1970, foram criadas 996 associações em São Paulo/SP, 1.093 no Rio de Janeiro/RJ e 459 em Belo Horizonte/MG. Já no próximo decênio (durante a transição do regime militar para a democracia) esse número duplicou e, no período de 1981 a 1990, quadruplicou em cada uma das cidades mencionadas (AVRITZER, 2000).

Para entender por que as associações e os movimentos populares foram

\footnotetext{
${ }^{9} \mathrm{Na}$ década de 90, passam a se organizar de forma autônoma, reivindicando para si o papel de ator social e não mais [tão somente] de apoio aos movimentos sociais. Conhecidos hoje como Organizações NãoGovernamentais - ONGs, expressão “criada pela Organização das Nações Unidas (ONU) na década de 40 para designar entidades não-oficiais que recebiam ajuda financeira de órgãos públicos para executar projetos de interesse social na área de 'desenvolvimento da comunidade"” (TEIXEIRA, 2003, p. 18).
} 
considerados novas maneiras de fazer política, é preciso conhecer um pouco sobre os caminhos percorridos pela sociedade civil na defesa de suas demandas perante o poder público local na transição democrática brasileira, ainda que apresentem caminhos e características diferentes entre si, por se tratarem de experiências concretas.

Renato Raul Boschi (1987) faz referência a associações de moradores de favelas espalhadas por diversas regiões metropolitanas do país - do Amazonas ao Rio Grande do $\mathrm{Sul}^{10}$. Segundo o autor, os casos pesquisados tinham em comum a questão da legalização da posse da terra, associada a campanhas de sensibilização da opinião pública e à alta capacidade de mobilização de recursos nos diversos momentos de concretização da ação coletiva. Nesse momento, a atuação de agentes de apoio externo, profissionais autônomos e organizações, teve importância fundamental para o sucesso dos movimentos populares.

Em todos os casos, a identidade das pessoas com o local de moradia legitimava o monopólio da representação política pelos próprios moradores como uma nova identidade coletiva (BOSCHI, 1987).

Entre as organizações de apoio externo, destacam-se a Igreja Católica e suas Comunidades Eclesiais de Base (CEBs), que auxiliaram os movimentos populares materialmente e na organização de campanhas de resistência e protesto. Nessas fases de mobilização popular, percebeu-se intensa negociação política entre os grupos sociais e as agências públicas sem a mediação da política tradicional. Tal relação institucional influenciava no curso dos acontecimentos, especialmente, nos eventos de ocupação de terras e propriedades. Na prática diária dos conflitos, o formato preferencial de encaminhamento e negociação de demandas se deu perante autarquias públicas e secretarias municipais (BOSCHI, 1987).

A ajuda de políticos ocorreu apenas em 5\% dos casos em nível municipal e $2 \%$ em níveis estadual e federal, demonstrando o declínio do papel do vereador ou dos deputados como interlocutores das demandas populares. Ainda que a cooptação dos movimentos seja uma realidade, que não pode ser desconsiderada, verificou-se que a barganha ou a cooptação política dos movimentos populares tiveram o objetivo de diminuir ou paralisar os protestos e ocupações de propriedades, diferente do modelo clientelista tradicional, direcionado a angariar votos (BOSCHI, 1987).

Como se vê, as novas associações e movimentos sociais, formados no final da década de 1970, demonstraram aversão à tradição clientelista e, ao mesmo tempo, descrédito

\footnotetext{
${ }^{10}$ Manaus/AM, Belém/PA, São Luís/MA, Fortaleza/CE, Campina Grande/PB, Recife/PE, Brasília/DF, Belo
} Horizonte/MG, Rio de Janeiro/RJ, São Paulo/SP e Curitiba/PR (BOSCHI, 1987). 
em relação a instituições tradicionais, representando uma mudança no padrão associativo até então vigente. Inovando a vida política brasileira, passaram a questionar a intermediação de demandas sociais por atores políticos partidários, reforçando sua autonomia, exigindo a apresentação de demandas e a negociação direta com o Estado. A partir daí, principalmente nas grandes cidades, essas novas práticas redefinem o jeito de fazer política e fazem emergir um número significativo de associações e outras formas de organização da sociedade civil por melhores serviços públicos (AVRITZER, 2002b).

Isso nos permite dizer que a política brasileira deixou de ser monopólio dos atores políticos tradicionais, notadamente, os parlamentares e governantes, "escapando" e transbordando para a sociedade civil. A representação política baseada no sistema políticopartidário-eleitoral passa a conviver com uma representação política na própria sociedade civil, baseada em outros parâmetros de legitimidade ${ }^{11}$.

Sobre esses novos atores, prefaciando a obra Quando novos personagens entraram em cena, do sociólogo Eder Sader, Marilena Chaúi indaga e responde:

Por que sujeito novo? Antes de mais nada, porque criado pelos próprios movimentos sociais populares do período: sua prática os põe como sujeitos sem que teorias prévias os houvessem constituído ou designado. [...] O novo sujeito é social; são os movimentos sociais populares em cujo interior indivíduos, até então dispersos e privatizados, passam a definir-se, a reconhecer-se mutuamente, a decidir e agir em conjunto e a redefinir-se a cada efeito resultante das decisões e atividades realizadas. (SADER, 2001, p. 10)

Referindo-se à outra época e a outro local, porém com características similares à formação de conselhos comunitários no final da década de 1970 no Brasil, Hanna Arendt lembra que:

Estes sistemas de governo nunca apareceram como resultado de uma tradição ou teoria revolucionária consciente, mas de um modo totalmente espontâneo; cada vez como se nunca tivesse havido nada semelhante antes.

Assim o sistema de conselho parece corresponder e brotar da própria experiência da ação política. Nesta direção, parece-me haver algo a ser descoberto, um princípio de organização completamente diferente que começa de baixo, continua para cima e afinal leva a um parlamento (ARENDT, 1981, p. 199, destaque nosso).

Entre outras formas de organização política da sociedade civil na transição

${ }^{11}$ Sobre os fundamentos teóricos da legitimidade da representação política da sociedade civil, rever o tópico 2.1 A democracia participativa na atualidade. 
democrática (1970 e 1980), podemos mencionar o Movimento de Defesa do Favelado em São Paulo; os Conselhos de Saúde da Zona Leste de São Paulo; o movimento pela melhoria do transporte público em Belo Horizonte; o Clube de Mães na periferia sul de São Paulo e; o movimento dos metalúrgicos de São Bernardo do Campo (GOHN, 1991; BOSCHI, 1987; SADER, 2001).

Aos poucos, uma nova relação entre o Estado e a sociedade civil vai se constituindo e se consolidando em torno da definição e da efetivação das necessidades coletivas, para além do âmbito meramente estatal, como se depreende do excerto a seguir:

Construídas na interface entre Estado e sociedade, essas arenas públicas permitem tornar a gestão pública permeável às aspirações e demandas emergentes da sociedade civil, retirando do Estado o monopólio da definição de uma agenda de prioridades e problemas pertinentes à vida em sociedade. E isso significa um outro modo de se construir uma noção de interesse público (PAOLI; TELLES, 2000, p. 121).

Essas mudanças consolidam a ideia de que a sociedade civil tem condições de pleitear suas demandas sem a intermediação de atores políticos tradicionais, inclusive, no que diz respeito à institucionalização da participação para a definição das prioridades públicas.

No bojo dessas mudanças político-sociais, em 1979, Reynaldo de Barros, então prefeito de São Paulo, cria um conselho comunitário composto de associações de classe, entidades assistenciais, associações de bairro e movimentos sociais por meio do Decreto Municipal $\mathrm{n}^{\mathrm{o}}$ 16.100/79. Este conselho se constituiu em instâncias regionais, com a finalidade de discutir o orçamento do município. Porém, devido à forma burocratizada de atendimento das demandas, a iniciativa não logrou êxito, continuando a Prefeitura Municipal a definir o orçamento de acordo com a orientação de seus gabinetes. De qualquer modo, foi uma das primeiras tentativas de institucionalizar a participação social no âmbito estatal desde o fechamento político de 1964 (GOHN, 2011).

Essa relação entre conselhos, políticas públicas e participação explicita um percurso muito próprio à redemocratização no Brasil, no qual o anseio pela participação da sociedade civil, comum em outros países da América Latina, aqui se traduziu no anseio por incidir sobre políticas públicas. Como inovação institucional, os conselhos selam esse encontro, essa aposta (ALMEIDA; CAYRES; TATAGIBA, 2015, p. 265).

Outro exemplo: na Porto Alegre de 1986, o ex-prefeito Alceu Collares (PDT) convida associações comunitárias para participarem de sua Administração Municipal. Em 
resposta, a União das Associações de Moradores de Porto Alegre (UAMPA) ressalta que:

\begin{abstract}
O mais importante na Prefeitura é a arrecadação e a definição de para onde vai o dinheiro público. É a partir daí que vamos ter ou não verbas para o atendimento das reivindicações das vilas e bairros populares. Por isso, queremos intervir diretamente na definição do orçamento municipal e queremos controlar a sua aplicação (UAMPA, 1986 apud AVRITZER, 2002a, p. 574, destaque nosso).
\end{abstract}

Como se vê, durante a redemocratização do país, os movimentos populares perceberam a importância de participarem do processo orçamentário a fim de viabilizar maiores e melhores políticas públicas sociais. Tal participação viria a ser reconhecida, quinze anos depois, pela Lei de Responsabilidade Fiscal (Lei Complementar Federal 101/00) e pelo Estatuto da Cidade (Lei Federal 10.257/01), com a obrigatória realização de audiências públicas no processo orçamentário municipal.

Essas lutas sociais continuaram na via institucional pelas "emendas populares", por meio das quais conseguiu-se incluir na Constituição Federal de 1988 diversos institutos de participação popular em diversas áreas temáticas: a) ordem social: artigos 10 e 194, VII ${ }^{12}$; b) planejamento urbano: artigo $29, \mathrm{XII}^{13}$; c) saúde: artigos 198 , III da CF e art. $77, \S^{\circ}$ do $\mathrm{ADCT}^{14}$; d) assistência social: artigo 204, $\mathrm{II}^{15}$; e) educação: $\operatorname{artigos} 205$ e 206, VI ${ }^{16}$; f) criança e adolescente: artigo 227 , caput do $\S 1^{\circ 17}$ e, mais recentemente, na área habitacional:

12 Art. 10. É assegurada a participação dos trabalhadores e empregadores nos colegiados dos órgãos públicos em que seus interesses profissionais ou previdenciários sejam objeto de discussão e deliberação; Art. 194. A seguridade social compreende um conjunto integrado de ações de iniciativa dos Poderes Públicos e da sociedade, destinadas a assegurar os direitos relativos à saúde, à previdência e à assistência social. VII - caráter democrático e descentralizado da administração, mediante gestão quadripartite, com participação dos trabalhadores, dos empregadores, dos aposentados e do Governo nos órgãos colegiados.

${ }^{13}$ Art. 29. O Município reger-se-á por lei orgânica, votada em dois turnos, com o interstício mínimo de dez dias, e aprovada por dois terços dos membros da Câmara Municipal, que a promulgará, atendidos os princípios estabelecidos nesta Constituição, na Constituição do respectivo Estado e os seguintes preceitos: XII cooperação das associações representativas no planejamento municipal;

${ }^{14}$ Art. 198. As ações e serviços públicos de saúde integram uma rede regionalizada e hierarquizada e constituem um sistema único, organizado de acordo com as seguintes diretrizes: III - participação da comunidade; Art. 77. Até o exercício financeiro de 2004, os recursos mínimos aplicados nas ações e serviços públicos de saúde serão equivalentes: $\S 3^{\circ}$ Os recursos dos Estados, do Distrito Federal e dos Municípios destinados às ações e serviços públicos de saúde e os transferidos pela União para a mesma finalidade serão aplicados por meio de Fundo de Saúde que será acompanhado e fiscalizado por Conselho de Saúde, sem prejuízo do disposto no art. 74 da Constituição Federal. (Incluído pela Emenda Constitucional nº 29, de 2000);

${ }^{15}$ Art. 204. As ações governamentais na área da assistência social serão realizadas com recursos do orçamento da seguridade social, previstos no art. 195, além de outras fontes, e organizadas com base nas seguintes diretrizes: II - participação da população, por meio de organizações representativas, na formulação das políticas e no controle das ações em todos os níveis.

${ }^{16}$ Art. 205. A educação, direito de todos e dever do Estado e da família, será promovida e incentivada com a colaboração da sociedade, visando ao pleno desenvolvimento da pessoa, seu preparo para o exercício da cidadania e sua qualificação para o trabalho; Art. 206. O ensino será ministrado com base nos seguintes princípios: VI - gestão democrática do ensino público, na forma da lei;

${ }^{17}$ Art. 227. É dever da família, da sociedade e do Estado assegurar à criança, ao adolescente e ao jovem, com 
art. 79 do $\mathrm{ADCT}^{18}$.

Em São Paulo, a Lei Orgânica do Município, promulgada em 4 de abril de 1990, previu que "a política municipal de habitação deverá prever a articulação e integração das ações do Poder Público e a participação popular das comunidades organizadas através de suas entidades representativas, bem como os instrumentos institucionais e financeiros para sua execução" (art. 168). Em complemento, determinou ainda que o Poder Municipal criasse, por lei, Conselhos compostos de representantes eleitos ou designados, a fim de assegurar a adequada participação de todos os cidadãos em suas decisões, especialmente, na elaboração do Plano Diretor, do Plano Plurianual, das diretrizes orçamentárias e do orçamento anual (art. $8^{\circ}$ e $\left.9^{\circ}\right)$.

No âmbito nacional, durante a década de 1990, dando-se concretude às normas constitucionais, diversas leis federais passaram a exigir a criação de Conselhos de Políticas Públicas nas esferas dos governos estadual e municipal como condição para o repasse de recursos federais. É o exemplo do Conselho de Direitos da Criança e do Adolescente (Lei Federal 8.069/90, art. 261, parágrafo único); do Conselho de Saúde (Lei Federal 8.080/90, art. 33) e; mais recentemente, do Conselho de Habitação (Lei Federal n 11.124/05, art. 12).

Desde a edição das referidas leis, tornou-se notória a presença de Conselhos na estrutura político-administrativa dos municípios brasileiros. Já em 1993, os Conselhos de Saúde existiam em 3.000 municípios; no ano seguinte, haviam 2.362 Conselhos Municipais na área da Criança e do Adolescente e; em 1997 contavam 2.908 Conselhos Municipais na área de Assistência Social (SANTOS, 2002 apud SANTOS JUNIOR, AZEVEDO, RIBEIRO, 2004).

No ano 2000 o Censo observou a existência de ao menos um Conselho em todos os municípios do país, com maior presença nas áreas de Saúde (98\%); Assistência Social (93\%), Criança e Adolescente (77\%) e Educação (73\%) (IBGE, 2001).

absoluta prioridade, o direito à vida, à saúde, à alimentação, à educação, ao lazer, à profissionalização, à cultura, à dignidade, ao respeito, à liberdade e à convivência familiar e comunitária, além de colocá-los a salvo de toda forma de negligência, discriminação, exploração, violência, crueldade e opressão. $\S 1^{\circ} \mathrm{O}$ Estado promoverá programas de assistência integral à saúde da criança, do adolescente e do jovem, admitida a participação de entidades não governamentais [...].

18 Art. 79. É instituído, para vigorar até o ano de 2010, no âmbito do Poder Executivo Federal, o Fundo de Combate e Erradicação da Pobreza, a ser regulado por lei complementar com o objetivo de viabilizar a todos os brasileiros acesso a níveis dignos de subsistência, cujos recursos serão aplicados em ações suplementares de nutrição, habitação, educação, saúde, reforço de renda familiar e outros programas de relevante interesse social voltados para melhoria da qualidade de vida. Parágrafo único. O Fundo previsto neste artigo terá Conselho Consultivo e de Acompanhamento que conte com a participação de representantes da sociedade civil, nos termos da lei. (Incluído pela Emenda Constitucional n 31, de 2000) (Vide Emenda Constitucional nº 67, de 2010). 
Em 2013, manteve-se a presença de pelo menos um Conselho Temático em todos os municípios brasileiros, o que comprova a consolidação dessa estrutura políticoadministrativa em todo o país (IBGE, 2013).

Na cidade de São Paulo, o Conselho Municipal de Habitação de São Paulo - CMH foi instituído somente em 2002 pela Lei Municipal 13.425/02, sob a iniciativa da então prefeita Marta Suplicy, filiada ao Partido dos Trabalhadores (PT).

Como se vê, os Conselhos Municipais de Políticas Públicas, tal como o compreendemos atualmente, foram gestados pela sociedade civil em resposta às crises política, econômica e sociais acumuladas durante o regime militar (1964-1985), até se constituírem como órgãos públicos na forma prevista pela Constituição Federal e leis infraconstitucionais, com presença marcante na atual organização político-administrativa brasileira.

No ponto seguinte, em que pesem a variedade de experiências locais e a escassez de literatura a respeito, buscaremos mencionar algumas das características, natureza jurídica e competências mais comumente citadas pela doutrina em relação aos Conselhos Municipais de Políticas Públicas.

\subsection{NATUREZA JURÍDICA, ATRIBUIÇÕES E DISCRICIONARIEDADE DOS CONSELHOS MUNICIPAIS DE POLÍTICAS PÚBLICAS}

Os Conselhos Municipais de Políticas Públicas, em geral, são órgãos administrativos colegiados de composição mista, governo e sociedade civil, de caráter permanente e cujo feixe de atribuições, previstas em lei, envolve sua participação institucional na elaboração, consulta e/ou fiscalização de políticas públicas municipais afetas a sua área de competência.

Isso implica, necessariamente, no direito-dever de participação dos Conselhos no processo de elaboração das políticas públicas setoriais de sua competência e que serão incluídas nos respectivos instrumentos legais de planejamento e orçamento - v.g. Plano Diretor Estratégico, Programa de Metas, Plano Plurianual, Lei de Diretrizes Orçamentárias e Lei Orçamentária Anual ${ }^{19}$.

${ }^{19}$ Para maiores detalhes sobre cada um desses instrumentos legais de planejamento e orçamento da política pública municipal, reservamos o tópico 4.5 Instrumentos de planejamento urbano e orçamento municipal de 
Por se tratar de distribuição do poder decisório e do exercício de atividade administrativa antes conferida ao Poder Executivo, a instituição do Conselho deve ser prevista em lei ordinária, quando no exercício de função decisória, e/ou mediante Decreto Executivo, quando no exercício de função consultiva ou fiscalizatória, ambos de iniciativa do Prefeito Municipal (PEREZ, 2004).

A respeito de sua natureza jurídica, há os que preferem qualificá-lo como órgão público não estatal ou órgão descentralizado e autônomo, o qual, por simples conveniência financeiro-administrativa, estaria integrado à estrutura da administração direta (SANTOS JUNIOR, AZEVEDO, RIBEIRO, 2004; LIBERATI, CYRINO, 2003; AUAD, 2007 e SÁNCHEZ MÓRON, 1980).

Outros consideram-no órgão público estatal de administração desconcentrada, inclusive para fins de subordinação ao poder hierárquico do Chefe do Poder Executivo, o qual poderia revisar os atos deliberados pelo Conselho (PEREZ, 2004).

Em vista de sua integração à estrutura da Administração Pública direta, o Conselho não possui personalidade jurídica. Não pode contrair obrigações, nem responde judicialmente por seus atos e apenas no tocante ao exercício de prerrogativas institucionais possui personalidade jurisdicional (PEREZ, 2004). Embora se vincule à Administração, os Conselhos têm autonomia para definirem suas regras e dinâmicas de funcionamento conforme as deliberações de seu colegiado (SANTOS JUNIOR, AZEVEDO, RIBEIRO, 2004).

Sua composição deve necessariamente contar com a participação de representantes do poder público e da sociedade civil, havendo também a possibilidade de membros de entidades profissionais, patronais, laborais ou até universidades participarem do Conselho, variando conforme previsto em lei. Há Conselhos com a participação majoritária, outros de composição paritária, outros ainda de composição minoritária do Poder Público (PEREZ, 2004).

Parte da doutrina recomenda, contudo, que a composição do Conselho siga o princípio da paridade, o qual não deve ser entendido apenas numericamente, mas, no sentido de equalizar substancialmente o poder político entre os representantes do poder público e da sociedade civil organizada, especialmente, os movimentos populares (GOHN, 2011; MOREIRA, 2002).

A natureza jurídica dos membros do Conselho corresponde ao gênero "agente

São Paulo. 
público". Os conselheiros representantes do Poder Executivo podem ser enquadrados em duas espécies: a) o Secretário Municipal como "agente político", representante direto do governo; b) os demais, "servidores públicos", comissionados ou efetivos, representantes da Administração Pública. Por sua vez, os representantes da sociedade civil enquadram-se na categoria de "particulares em colaboração com o Poder Público" pelo exercício de função pública relevante, sem vínculo empregatício ou funcional, podendo ou não receber remuneração (DI PIETRO, 2014).

Quanto à forma de escolha, os conselheiros do governo são indicados pelo Poder Executivo, havendo casos em que ele também indica os representantes da sociedade civil. Mas, em favor do princípio da paridade, entendemos que os representantes da sociedade civil devem ser escolhidos pelo voto de seus pares, em fóruns especialmente instituídos para esse fim (assembleias gerais, conferências municipais etc.) ou pelo sufrágio da população em geral (PEREZ, 2004).

O mandato dos conselheiros é periódico, normalmente, com a duração de dois anos. A literatura recomenda que o fim do mandato não coincida com o fim ou início do mandato do Chefe do Poder Executivo para evitar a descontinuidade das políticas públicas discutidas no Conselho. Alguns autores entendem que o mandato do conselheiro deve ser imperativo, isto é, podendo ser revogado pelo voto de desconfiança da organização a qual representa. De qualquer maneira, qualquer hipótese de perda do mandato deve ser prevista na lei instituidora ou no respectivo Regimento Interno (MENDES, 2004; AUAD, 2007).

Outros autores, porém, entendem que o mandato dos representantes da sociedade civil deve ser de natureza representativa, senão os interesses particulares das organizações representadas poderão sobrepor-se aos interesses da categoria social as quais pertencem (SANCHEZ MORÓN, 1980).

Os Conselhos podem receber atribuições orçamentárias afetas a uma ou várias áreas temáticas de políticas públicas, bem como exercerem funções de fiscalização, consulta ou deliberação ${ }^{20}$ exclusivamente sobre o feixe de atribuições/competências estendidas por lei ou decreto.

No exercício da função de físcalização, os Conselhos poderão controlar a movimentação de recursos financeiros, bem como verificar se a execução das políticas

20 No presente trabalho, importante destacar, trataremos especificamente dos Conselhos Municipais de Políticas Públicas cuja função legalmente prevista seja deliberativa e consultiva sobre o orçamento; os quais, para exercerem tais atribuições precisam também estar incumbidos da função fiscalizatória como decorrência natural do controle social. 
públicas observa o disposto nas leis orçamentárias (PPA, LDO e LOA) e demais diretrizes normativas que informa a política pública. Na qualidade de órgãos públicos, terão a prerrogativa de requisitar informações de outros órgãos públicos ou privados para esclarecer assuntos de sua competência legal.

A respeito da competência fiscalizatória, Luciana Tatagiba ressalta que "os conselhos têm poder de veto sobre as decisões do governo, podendo paralisar obras, vetar convênios, suspender o repasse de recursos etc." (TATAGIBA, 2010, p. 35). Isto porque o exercício dessa competência pressupõe um poder discricionário do Conselho sobre os aspectos formais e materiais estipulados nas normas jurídicas mencionadas no parágrafo anterior.

A função consultiva confere ao Conselho a prerrogativa de ser consultado antes da tomada de decisão pelo Poder Executivo, sempre que a decisão envolver políticas públicas de competência do Conselho. Nesse sentido, podemos citar duas ações diretas de inconstitucionalidade ajuizadas perante o Tribunal de Justiça do Estado de São Paulo (TJSP) em face de Planos Diretores encaminhados pela Prefeitura e aprovados pela Câmara Municipal, mas que não foram submetidos à consulta do Conselho Municipal do Meio Ambiente, respectivamente, de Caraguatatuba e Mogi das Cruzes. Ambas as ações foram julgadas procedentes para declarar a inconstitucionalidade dos referidos Planos Diretores ${ }^{21}$.

A função deliberativa confere ao Conselho a competência legal de dar início, instruir e deliberar sobre as políticas públicas cuja competência tenha lhe sido atribuída por lei, formalizando-as por meio de Resoluções.

Sobre a função deliberativa, surge a seguinte questão: tendo a lei atribuído competência deliberativa ao Conselho, as decisões do Conselho vincularão a vontade do Chefe do Poder Executivo ou poderão ser revogadas por ele?

Ao tratar da questão, alguns autores defendem que a deliberação do Conselho vincularia a vontade estatal, sob pena de subverter a própria lógica da participação e a natureza jurídica de órgão descentralizado e autônomo (LIBERATI, CYRINO, 2003; AUAD, 2007; AMANDO DE BARROS, 2012).

Outros autores, ao contrário, entendem que a decisão do Conselho, cuja natureza jurídica seria de administração desconcentrada, não poderia se sobrepor à vontade da autoridade superior da Administração Pública, sob pena de afrontar a legitimidade popular obtida nas eleições. Então, sob essa perspectiva, a deliberação do Conselho não poderia

${ }^{21}$ TJSP, ADI n ${ }^{\circ}$ 0083103-85.2012.8.26.0000, Relator: Des. Antônio Luiz Pires Neto; TJSP, ADI n 020764430.2011.8.26.0000, Relator Des. Walter de Almeida Guilherme. 
vincular a vontade do Chefe do Poder Executivo (MOREIRA, 2002; PEREZ, 2004; ASSONI FILHO, 2011).

Merece destaque a solução encontrada por Gustavo Justino de Oliveira (2005; 1997) e por Diogo de Figueiredo Moreira Neto (1992; 1997). Os autores defendem que a vinculação da vontade do Chefe do Poder Executivo dependerá do grau de intensidade ou nível de profundidade dos mecanismos de participação.

Gustavo Justino de Oliveira (2005) diferencia as fases procedimentais em que a participação popular incide, quais sejam: a) participação na fase preparatória, instrutória, informativa ou pré-decisional; b) participação na fase decisória propriamente dita ou; c) participação na fase executória como prestador ou executor da política pública.

$\mathrm{Na}$ fase preparatória, a participação se destina a instruir o processo administrativo com informações, sugestões e opiniões, tendo caráter preponderantemente de consulta e diálogo entre Administração e cidadãos. Nesse caso, as sugestões dos interessados não vinculam a Administração, no entanto, a decisão final deve considerá-las em sua fundamentação, explicitando as razões de acolhimento ou rejeição, e se basear nos elementos colhidos na fase preparatória, reduzindo o grau de discricionariedade da decisão administrativa (OLIVEIRA, 2005).

$\mathrm{Na}$ fase de execução, eventuais modificações ou sugestões não poderão comprometer a substância do programa de trabalho apresentado pela Administração Pública. Trata-se das hipóteses de concessão ou permissão de serviço público previstas no artigo 175 da Constituição Federal. Ainda assim, a palavra final caberá ao órgão público, que exerce a função de supervisão sobre a atividade do particular (MOREIRA NETO, 1992; OLIVEIRA, 2005).

Na fase decisória, o Conselho recebe atribuições previstas em lei para instaurar, instruir e proferir decisão sobre tema de competência. Logo, tratando-se do exercício de competência prevista em lei, gera uma condição vinculatória para toda a Administração Pública, inclusive para o Chefe do Poder Executivo (OLIVEIRA, 2005). Em outras palavras, "trata-se de um órgão popular de decisão e uma nova função orgânica no sistema existente na administração pública, comprometendo-se, em consequência, o exercício de função similar por órgão regular da estrutura do Poder Executivo" (MOREIRA NETO, 1992).

Quando se tratar do exercício direto de poder decisório, antes conferido ao Prefeito Municipal, exige-se que a criação do Conselho se dê por lei de iniciativa do Poder Executivo, como bem esclarece Diogo Moreira Figueiredo Neto: 


\begin{abstract}
Nessas condições, no direito brasileiro elas necessitam de previsão legal, uma vez que o exercício direto do poder, ou seja, com dispensa de representantes políticos, só se admite nos termos da Constituição (art. $1^{\circ}$, parágrafo único, in fine), através de lei específica (art. 48, X, no que respeita a funções, e XI, no que respeita a órgãos), sempre de iniciativa do Poder Executivo (art. 61, § 1, II, e). Como se observa, essa eficácia limitativa ou condicionadora dos poderes da Administração, que decorrerá da vontade vinculatória expressa em audiência pública, terá que ser sempre prevista numa lei específica para cada tipo de atuação administrativa de que se cogite, com a manifestação de vontade conjugada dos Poderes Legislativo e Executivo, porque importa, afinal, numa renúncia de poder por parte do Estado (MOREIRA NETO, 1997, p. 14).
\end{abstract}

Ante o exposto, fica evidenciado que os Conselhos possuem independência tanto na emissão de pareceres (função consultiva), quanto na realização de diligências fiscalizatórias (função fiscalizadora), como também na deliberação sobre as matérias de sua competência legal e, nesse caso, seguindo o entendimento de Gustavo Justino de Oliveira (1997; 2005) e de Diogo de Figueiredo Moreira Neto (1992; 1997), vinculando a vontade do Poder Executivo.

Nesse sentido - pela vinculação e efetividade das Resoluções aprovadas pelos Conselhos, pronunciou-se o Superior Tribunal de Justiça - STJ:

O pedido foi a implementação de um programa adredemente estabelecido
por um órgão do próprio município, o Conselho Municipal dos Direitos da
Criança e do Adolescente, com função normativa fixada em conjugação
com o Estado (Município) e a sociedade civil. O descumprimento à
Resolução $4 / 97$ foi apurado pelo MINISTÉRIO PÚBLICO, via
inquérito civil, no qual ficou concluída a insuficiência no
atendimento às crianças e adolescentes com problemas de uso de
drogas. [...] O moderno Direito Administrativo tem respaldo
constitucional suficiente para assumir postura de parceria e, dessa
forma, ser compelido, ou compelir os seus parceiros a cumprir os
programas traçados conjuntamente. Com essas considerações, dou
provimento ao recurso especial para julgar procedente em parte a
ação ministerial, determinando seja reativado em sessenta dias o
programa constante da Resolução 4/97, devendo ser incluído no
próximo orçamento Municipal verba própria e suficiente para
atender ao programa (STJ, REsp 493.811/SP, Rel. Ministra Eliana
Calmon, Segunda Turma, julgado em $11 / 11 / 2003$, DJ $15 / 03 / 2004$, p.
236).

Assim como expôs o STJ, o Conselho, enquanto órgão da Administração Pública legalmente instituído, possui discricionariedade administrativa sobre os temas inseridos em seu feixe de competências. Logo, os demais órgãos administrativos têm o dever de dar 
cumprimento às deliberações entabuladas pelos Conselhos, cabendo aos demais órgãos, tão somente, a escolha da maneira de execução do ditame legal sem se eximirem do dever legalmente imposto.

Em relação à natureza jurídica do ato administrativo emanado pelo Conselho, as Resoluções podem ser classificadas como ato complexo, por envolverem a participação de uma pluralidade de indivíduos (ato coletivo) e, ao mesmo tempo, como ato composto, ante a presença de representantes de uma pluralidade de entidades - movimentos sociais, organizações da sociedade civil, universidades, secretarias de governo e até de entidades da administração indireta (JUSTEN FILHO, 2014).

Quanto à responsabilidade pelos atos praticados no exercício do mandato, os conselheiros são equiparados aos agentes públicos para efeitos de responsabilidade civil, administrativa e criminal (PEREZ, 2004).

No tópico seguinte, apresentaremos a problematização que embasou a delimitação do tema de pesquisa em torno dos procedimentos administrativos aplicáveis aos Conselhos e da participação dos Conselhos no processo orçamentário municipal de São Paulo, com destaque para o $\mathrm{CMH}$.

\section{$\begin{array}{lllllll}2.5 & \text { OS PROCEDIMENTOS ADMINISTRATIVOS E } & \text { O PROCESSO }\end{array}$ ORÇAMENTÁRIO NOS CONSELHOS: OBJETOS DE PESQUISA}

No decorrer deste capítulo verificamos a inovação institucional dos Conselhos Municipais de Políticas Públicas na estrutura político-administrativa dos municípios brasileiros, com a inclusão da participação popular no processo de elaboração de políticas públicas e no controle das despesas públicas. No entanto, embora se trate de mais de duas décadas, a literatura especializada aponta que os Conselhos ainda têm se destacado mais como instâncias de fiscalização do que pela proposição de políticas públicas ou pela redefinição política dos gastos públicos. Além disso, apresentam-se como desafios institucionais a tarefa de garantir a capilaridade social dos Conselhos e a necessidade de haver maiores e melhores mecanismos de prestação de contas à sociedade em geral (TATAGIBA, 2010; MIGUEL, 2003; LAVALLE; HOUTZAGER; CASTELLO, 2006; AUAD, 2007).

Sobre o primeiro problema, pesquisa realizada em 111 (cento e onze) Conselhos 
Municipais de Direitos da Criança e do Adolescente (CMDCA) de Minas Gerais apontou que $67 \%$ dos Conselhos pesquisados não haviam formulado programas e diretrizes de educação e saúde para a infância e juventude, como determinam as diretrizes do Conselho Nacional dos Direitos da Criança e do Adolescente (CONANDA). As entrevistas revelaram ainda que os conselheiros não tinham informações sobre a gestão dos recursos do Fundo dos Direitos da Criança e do Adolescente, quanto possuem e para o que se destinavam, embora a legislação atribua a gestão do Fundo ao CMDCA. Segundo a pesquisa, na maioria dos casos, tais informações permaneciam restritas ao Poder Executivo municipal (CARNEIRO, 2006).

Embora se referindo à esfera federal, a mesma problemática foi observada por Márcio Luiz de Albuquerque Oliveira (2014) quanto ao grau de influência do CONANDA na elaboração das peças orçamentárias de 2014, conforme se depreende a seguir:

[...] a minha impressão é que estávamos falando de coisas totalmente diferentes, a linguagem não era a mesma, só se falava de política e na hora que ia trazer para o orçamento, havia uma grande dificuldade e um desconhecimento sobre o assunto (ENTREVISTADO I, 2014) (OLIVEIRA, 2014, p. 52) 22 .

[...] até agora são dois mundos distintos. A construção da política e a relação orçamentária. São dois territórios que não se conversam, são distintos (ENTREVISTADO, F, 2014). (OLIVEIRA, 2014, p. 52).

$\mathrm{O}$ autor ressalta que o relato sobre os "mundos distintos" deixa evidente o descompasso entre as deliberações dos Conselhos e a efetiva alocação orçamentária em políticas públicas (OLIVEIRA, 2014).

Como se vê, ao mesmo tempo em que Administração Pública se abre à participação popular, nega-lhe condições de interferir no processo de elaboração e gerenciamento dos recursos públicos. Por consequência, a finalidade institucional dos Conselhos fica comprometida. Nesse sentido, advertem Sérgio Assoni Filho (2009) e Denise Cristina Vitale Ramos Mendes (2004):

As organizações de caráter político emergentes no meio social, doravante identificáveis com o conceito de sociedade civil, pouco podem fazer para influírem nas ações e decisões governamentais, caso suas atenções também não estejam direcionadas ao gerenciamento e à utilização dos recursos financeiros em posse da Administração Pública (ASSONI FILHO, 2009,

22 Devido ao grande número de erros de gramática (ortografia, regência, concordância etc.), optamos, propositadamente, por não indicar tais erros ("sic") a fim de não descaracterizar a identidade dos discursos, não sobrecarregar o texto original e não prejudicar ainda mais a clareza da leitura. 
p. 89).

O objetivo de instituir em estatutos jurídicos as diretrizes participativas na elaboração das leis orçamentárias não foi, apenas, para indicar uma nova orientação aos administradores públicos, mas, sobretudo, para revesti-las de status jurídico com vistas, justamente, à sua garantia. Institucionalizar juridicamente procedimentos significa poder assegurá-los juridicamente. Significa permitir que, tanto sua realização, como seus resultados possam ser objetos de discussão no Judiciário, tendo por base uma fundamentação legal mais determinada (MENDES, 2004, p. 281).

Estes dados indicam a baixa influência dos Conselhos na definição da agenda e na proposição das políticas públicas e, consequentemente, na elaboração das peças orçamentárias. Apontam também a inobservância de princípios e regras processuais, especialmente, de cunho instrutório (informação) em desfavor dos conselheiros.

Um segundo problema diz respeito à legitimidade da representação extraparlamentar ${ }^{23}$, a qual deve se submeter a mecanismos de controle, sanção e prestação de contas às entidades representadas e à sociedade em geral. Contudo, não é raro situações em que a plenária das entidades sociais ou profissionais encontre seu representante apenas no dia da eleição e não tenha retorno das decisões tomadas no Conselho (TATAGIBA, 2010).

Outra pesquisa, realizada em Chapecó/RS e Itajaí/RS, indicou que, em média, metade dos conselheiros raramente, quase nunca ou nunca são orientados por suas entidades na hora de tomar decisões, inclusive os representantes da sociedade civil e dos movimentos populares (BORBA; LÜCHMANN, 2010). A título de exemplo, confira-se a manifestação de um conselheiro de saúde do Município de Itajaí-SC:

Porque na prática, hoje, eu falo por mim, um pouco do que eu falo também vale para outros conselheiros, cada conselheiro acaba representando a si mesmo. Apesar de estar lá representando os farmacêuticos, eu não saberia dizer qual é a opinião dos farmacêuticos em determinadas posições. Enquanto conselheiro você tem que definir algumas coisas. Então, eu particularmente acho que a gente tá muito longe, a categoria tá muito longe de uma organização ao ponto de colocar um conselheiro e realmente depois cobrar desse conselheiro, pedir o retorno das decisões que são tomadas (Conselheiro, representante dos profissionais de saúde - Itajaí-SC). (BORBA; LÜCHMANN, 2010, p. 241, grifo nosso).

Por essa razão, Ana Cláudia Chaves Teixeira enfatiza a necessidade de promover alterações na legislação sobre os conselhos prevendo mecanismos legais de prestação de

\footnotetext{
${ }^{23}$ Para maiores detalhes, remeto o leitor ao tópico 2.1 A democracia participativa na atualidade.
} 
contas "seja através de reuniões, boletins informativos ou outras possibilidades" (TEIXEIRA, 2005, p. 58-59). Nesse sentido, a legitimidade da representação política dos conselheiros passa a depender da adoção de mecanismos de controle e prestação de contas à sociedade em geral, cuja previsão deve obrigatoriamente constar dos regimentos internos dos Conselhos.

Como se vê, muitas e variadas ações são necessárias para o aprimoramento e fortalecimento dos Conselhos. Dentre elas, sua inovação institucional requer a adequada participação dos Conselhos na formulação das políticas públicas de sua competência, o que implica, necessariamente, em participar do processo orçamentário municipal. Além disso, o funcionamento adequado dos Conselhos exige que se observem os princípios e regras processuais inerentes ao processo administrativo, tanto em relação aos conselheiros quanto aos interessados potencialmente afetados pelas decisões, principalmente, quanto às garantias da ampla defesa e do contraditório. Por fim, não é possível falar em legitimidade dos conselheiros sem mecanismos de controle social, sanção e prestação de contas à sociedade em geral.

A fim de analisar a problemática citada no parágrafo anterior, nos capítulos subsequentes, abordaremos o regime jurídico dos procedimentos administrativos aplicáveis aos Conselhos e, em seguida, pesquisaremos as regras inerentes à participação dos Conselhos no processo orçamentário municipal de São Paulo. Por fim, no último capítulo, com base no referencial teórico construído nos capítulos antecedentes, procederemos ao estudo de caso do Conselho Municipal de Habitação de São Paulo. 


\section{REGIME JURÍDICO DOS PROCEDIMENTOS ADMINISTRATIVOS APLICÁVEIS AOS CONSELHOS}

O espraiamento das funções estatais sobre as políticas socioeconômicas e a correspondente mediação dos diversos interesses envolvidos têm exigido reformulações da própria atividade administrativa. Uma das soluções encontradas tem sido a utilização de instrumentos próprios da chamada democracia participativa, a exemplo dos Conselhos analisados no capítulo anterior.

Porém, como se viu, o funcionamento dos Conselhos vem encontrando obstáculos de natureza processual, isto é, de cunho instrutório. Por essa razão, faz-se necessário estudar os meios pelos quais a participação se realiza, traduzidos em termos jurídicos em processos ou procedimentos administrativos.

Com esse intuito, apresentaremos no presente capítulo o regime jurídico dos procedimentos administrativos aplicáveis aos Conselhos, o qual representa o primeiro objetivo geral da presente pesquisa.

Já, no tópico seguinte, veremos que a formulação das políticas públicas deve se submeter a procedimentos administrativos com a participação popular em seu processo decisório. Situação que se adequada à institucionalização dos Conselhos de Políticas Públicas.

\subsection{PROCEDIMENTALIZAÇÃO DA ATIVIDADE ADMINISTRATIVA}

Segundo Marçal Justen Filho (2014), a procedimentalização ou processualidade da atividade administrativa significa a necessidade de que as decisões administrativas surjam como conclusão de uma série ordenada de atos, estruturados entre si, de modo a propiciar a participação de todos os interessados (não apenas os agentes públicos), a ampla realidade dos fatos, a exposição dos motivos determinantes para as escolhas adotadas e a submissão à revisão de entendimentos.

A pertinência e indispensabilidade do procedimento administrativo justificam-se pelas seguintes razões: a) a insuficiência dos conceitos jurídicos indeterminados utilizados 
na lei para lidar com a imprevisibilidade das necessidades coletivas e a dificuldade de enquadrá-las no caso concreto a partir de simples silogismo; b) a atuação cada vez mais presente da própria Administração na elaboração das leis e atos normativos; c) preocupação com a efetividade dos direitos previstos na Constituição; d) surgimento de um grande número de associações e entidades de pressão sobre a Administração visando interferir em suas decisões etc. Também por essas razões, o dogma da constituição da vontade unilateral do Estado abre espaço à consensualidade e participação (DUARTE, 1996; MEDAUAR, $2009)^{24}$.

Nesse sentido, o direito administrativo, ao invés de atuar apenas como limite à ação estatal, passa a orientar a realização dos objetivos imediatos e mediatos da Administração Pública, com a participação dos cidadãos na formulação de alternativas para os problemas sociais. Disso logo se depreende a importância dos processos administrativos para a formação e a evolução do próprio direito administrativo (CAETANO, 1967).

Marçal Justen Filho indica que a submissão da atividade da Administração Pública ao procedimento é fundamento do regime de direito administrativo consagrado no art. $5^{\circ}$, incisos LIV e LV, da Constituição Federal de 1988, os quais determinam que se observe o devido processo legal, o contraditório e a ampla defesa dos litigantes, com os meios e recursos a ela inerentes. Orientações essas que devem ser conjugadas com o princípio jurídico do Estado Democrático de Direito, segundo o qual o "poder emana do povo, que o exerce por meio de representantes eleitos ou diretamente, nos termos desta Constituição" (art. $1^{\circ}$, parágrafo único da $\mathrm{CF}$ ). Em razão desse preceito constitucional, "a observância de procedimentos democráticos, com ampla participação da população, é um fator constitutivo da validade da atividade administrativa" (JUSTEN FILHO, 2014).

Vimos assim que a expressão "procedimentalização" equivale à participação da sociedade civil em procedimentos administrativos destinados à tomada de decisões políticas, cujas características principais serão expostas a seguir.

A existência da participação procedimental pressupõe a ampla investigação da realidade dos fatos por meio de uma fase reservada à instrução, com a participação dos interessados em potencial, e que a decisão exponha os motivos determinantes para as

\footnotetext{
${ }^{24}$ No mesmo sentido, confira o entendimento de Celso Antônio Bandeira de Mello: “[...] vejamos agora a importância do procedimento. Seu relevo decorre do fato de ser um meio apto a controlar o 'iter' de formação das decisões estatais, o que passou a ser um recurso extremamente necessário a partir da multiplicação e do aprofundamento das ingerências do Poder Público sobre a Sociedade. Estas se alargaram e se intensificaram como fruto das profundas transformações ocorridas na concepção de Estado e, pois, das missões que lhe são próprias" (BANDEIRA DE MELLO, 2014, p. 502).
} 
escolhas adotadas, como requisito de validade da atividade administrativa (JUSTEN FILHO, 2014).

Para Niklas Luhmann (1980), as decisões finais dependem, em grande medida, da escolha das formas de organização e de fluxo da informação. Considerando que as decisões administrativas costumam tratar de problemas concretos, em que diversas alternativas são possíveis e defensáveis, o próprio processo de seleção e condução adquire um peso real. Importante saber então quais informações serão consideradas ou desprezadas e seus motivos, os custos e diligências possíveis para averiguação dessas informações e as alternativas apresentadas no curso do procedimento.

Quanto maior for a dúvida que a decisão política envolver, maior será a necessidade de reduzi-la e, portanto, "maior a relevância do procedimento como meio de esclarecimento das incertezas retrospectivamente projectadas" (DUARTE, 1996).

Aos que se ocupam de legislar sobre o processo administrativo, Niklas Luhmann recomenda a racionalização interna do método de decisão administrativa a partir de um elevado grau de especialização e frequente revisão e aperfeiçoamento do processo (LUHMANN, 1980).

Expostas suas características principais, a seguir analisaremos as principais finalidades e funções da procedimentalização da atividade administrativa.

De acordo com João Paulo Bachur (2008), o procedimento teria por objetivo neutralizar a insatisfação dos participantes, independentemente de se chegar a uma decisão justa ou injusta, favorável ou desfavorável. Isto seria possível à medida que as expectativas individuais fossem reestruturadas e ajustadas durante o procedimento convertendo-se o inconformismo individual em resignação antes mesmo da decisão final.

Segundo Odete Medauar, o processo administrativo teria a função de propiciar a tomada de decisões mais justas e eficazes, ao permitir que os interessados contribuam com informações mais condizentes com a realidade. Além disso, a partir do processo administrativo, torna-se possível averiguar: a) se a decisão foi congruente com os elementos colhidos no procedimento - fato este relacionado com a legitimidade da decisão; b) se o gestor público desempenhou corretamente sua função (MEDAUAR, 2008).

É relevante destacar que o procedimento administrativo tem a capacidade de reduzir o "complexo universo de interesses". Já que o procedimento limita o ambiente externo (sociedade) e o ambiente interno (atores envolvidos no procedimento); fixa um tempo para sua conclusão e; organiza a ação administrativa. Assim, mesmo que a margem de ignorância e o risco sejam inevitáveis, a procedimentalização propicia um ambiente possível para a 
tomada de decisões de alta complexidade - a exemplo do planejamento urbano (DUARTE, 1996).

Concluímos. A abertura da Administração a influências da sociedade, principalmente, as grandes empresas, legitima a institucionalização de procedimentos administrativos abertos à participação popular em seu processo decisório.

\subsection{PROCESSO OU PROCEDIMENTO ADMINISTRATIVO}

Ao iniciarmos nossos estudos sobre a participação popular na Administração Pública e, especialmente, nos Conselhos de Políticas Públicas, deparamo-nos com um debate inconciliável na doutrinária jurídica sobre a utilização do termo "processo administrativo" ou "procedimento administrativo".

Para alguns autores, "processo" seria o "procedimento em contraditório" e "procedimento" significaria a mera exteriorização (formal) dos atos que compõem o processo. Processo representaria uma relação jurídica, de caráter processual em sentido estrito, enquanto o procedimento configuraria o mero desenrolar dos atos e fatos do primeiro e não uma relação jurídica propriamente dita (CINTRA, GRINOVER e DINAMARCO, 2015; BUCCI, 2013; DI PIETRO, 2014; MOREIRA, 2010).

Prosseguindo-se no debate doutrinário, Lúcia Valle Figueiredo (2008) e Marçal Justen Filho (2014) aceitam o termo "processo" para a defesa de direitos e interesses privados. Porém, reservam o termo "procedimento" quando seu objeto se referia a interesses difusos ou coletivos.

Celso Antônio Bandeira de Mello, em suas palavras, deixa de lado o "cavalo de batalha" e utiliza de modo indiferente os termos "processo" e "procedimento" (BANDEIRA DE MELLO, 2014).

Em artigo monográfico sobre audiências públicas, apesar de demonstrar preferência pela expressão "processo" que dá nome ao seu artigo, Gustavo Justino de Oliveira (1997) utiliza os termos processo e procedimento de modo indiferente.

No mesmo sentido, Carlos Ari Sundfeld utiliza os termos de modo indiferente, como se depreende dos trechos: "O que é uma lei geral de procedimento (ou processo) administrativo?" ou "As leis de procedimento (ou processo) administrativo são consideradas instrumentos fundamentais do Estado de Direito e da cidadania, na generalidade dos Estados 
democráticos" (SUNDFELF, 2006, p. 17-36).

Ademais, nem a Constituição Federal nem a legislação esclarecem quando um determinado modo de proceder da Administração se enquadraria sob o título de "processo" ou "procedimento", vide a Lei de Processo Administrativo Estadual de São Paulo - LPAE, que regula o processo administrativo e, ao mesmo tempo, refere-se a "procedimentos" em diversos dispositivos legais (v.g. Título IV - Dos Procedimentos Administrativos).

Ante o exposto, tal como Bandeira de Mello (2014), Justino de Oliveira (1997) e Sundfeld (2006), entendemos que ambos os termos "processo" e "procedimento" podem ser utilizados para se referir às relações jurídicas processuais em contraditório.

\subsection{PRINCÍPIOS DO PROCEDIMENTO (PROCESSO) ADMINISTRATIVO}

A seguir, apresentaremos os princípios gerais do direito administrativo e do processo (ou procedimento) administrativo que entendemos de maior relevância para a compreensão da participação procedimental nos Conselhos.

\subsubsection{Princípio do devido processo legal ou do formalismo moderado}

O princípio do devido processo legal tem previsão no artigo $5^{\circ}$, incisos LIV e LV, associado ao parágrafo único do art. $1^{\circ}$, ambos, da Constituição Federal, segundo os quais o processo decisório da Administração Pública deve respeitar o direito de manifestação dos interessados, bem como seguir o rito procedimental inscrito nas normas jurídicas.

A fim de assegurar a observância do devido processo legal, os interessados têm a prerrogativa de se opor à direção conferida ao procedimento quando em descompasso com as finalidades da atuação estatal. Em síntese, o referido princípio equivale à garantia concreta do princípio da legalidade (MEDAUAR, 2008).

Nesse sentido, Sérgio Ferraz e Adilson de Abreu Dallari destacam que os cidadãos podem se valer do Poder Judiciário para declarar a nulidade de um ato administrativo praticado em afronta aos princípios da legalidade, da razoabilidade ou da proporcionalidade (FERRAZ; DALLARI, 2012). 
Não obstante, fazendo remissão ao princípio da utilidade ou da efetividade do procedimento, Marçal Justen Filho ressalta que a formalidade deve se restringir ao quanto útil ou necessário para que se atinja a finalidade do ato. $\mathrm{O}$ autor ainda faz referência ao princípio do informalismo, com base no que a Administração não pode opor rigorismos formais às manifestações dos interessados (JUSTEN FILHO, 2014).

Em complemento, Maria Sylvia Zanella Di Pietro destaca que o princípio do informalismo vem consagrado também em favor da Administração Pública em diversos estatutos legais ${ }^{25}$. E, ressalvados os casos envolvendo direitos particulares, devem ser aplicados os princípios da razoabilidade e da proporcionalidade em relação às formas do procedimento (DI PIETRO, 2014).

Odete Medauar considera que o predicativo "informalismo" pode dar a entender que o processo administrativo não tenha ritos ou formas. Prefere assim utilizar o termo "formalismo moderado", a partir do qual as formas e ritos do processo devem ser simples e razoáveis o bastante para garantir a certeza e segurança aos direitos dos sujeitos. Os adjetivos "simples" e "razoáveis" significam que as formalidades não devem ser consideradas um fim em si mesmas, devendo ser flexibilizadas para atingir à finalidade do processo, desde que não sirvam para sanar nulidades ou escusar o cumprimento da lei (MEDAUAR, 2014).

Quanto ao conteúdo do processo administrativo e das respectivas decisões, o princípio do devido processo legal se confunde com a atribuição ou competência prevista em lei, de modo que os Conselhos "não podem deliberar sobre matérias que extrapolem os setores das políticas sociais sob sua responsabilidade, bem sobre questões que extravasem o âmbito de atuação da esfera de governo pela qual foram criados” (MOREIRA, 2002, p. 23).

Deste modo, verificamos que as formas do procedimento no âmbito dos Conselhos podem ser flexibilizadas para se atingir o interesse público previsto na lei, de modo algum para sanar nulidade ou afastar seu cumprimento.

\subsubsection{Princípio da igualdade, impessoalidade ou imparcialidade}

Nos Conselhos, o princípio da igualdade relaciona-se com o princípio da paridade,

\footnotetext{
${ }^{25}$ Cf. artigo 305 do Estatuto dos Funcionários Públicos Civis do Estado de São Paulo (Lei no 10.261/68, com a redação dada pela Lei Complementar $n^{\circ} 942 / 03$ ) e nos artigos $2^{\circ}$, incisos VIII e IX, e 22 da Lei Federal $n^{\circ}$ 9.784/99/99 (DI PIETRO, 2014).
} 
que, por sua vez, não deve ser visto apenas sob a dimensão numérica, mas como garantia de igualdade substancial ou real entre os conselheiros.

Nesse sentido, aos conselheiros deve se assegurar "paridade em armas sempre que alguma causa ou circunstância exterior ao processo ponha uma delas em condições de superioridade ou de inferioridade em face da outra". Isto quer dizer: os substancialmente iguais merecem tratamento igual e os substancialmente desiguais necessitam de tratamento desigual a fim de que a desigualdade seja substancialmente reequilibrada (CINTRA; GRINOVER; DINAMARCO, 2015, p. 78).

Aliás, grande parte da inefetividade dos Conselhos é atribuída justamente à "desigualdade de armas" entre os conselheiros da sociedade civil e os conselheiros do governo. Os representantes do governo são, obrigatoriamente, servidores públicos e, por isso, têm acesso privilegiado a informações e documentos à disposição da Administração. Os representantes da sociedade civil, por sua vez, cada qual exercendo seu ofício, dependem das informações prestadas pela Administração. Por isso, em nome do princípio da igualdade ou da paridade exigem-se ações positivas que amenizem tais assimetrias, como por exemplo: capacitação dos conselheiros; disponibilização de infraestrutura e de pessoal administrativo encarregado especialmente das atividades do Conselho (AUAD, 2007; TEIXEIRA, 2000).

A efetivação do princípio da impessoalidade ou imparcialidade no procedimento administrativo é complementada, ainda, pela observância de outros princípios jurídicos, tais como o princípio da moralidade, da publicidade, do contraditório e da ampla defesa quanto à igual oportunidade de manifestação e de produção de provas entre todos os conselheiros (MEDAUAR, 2006).

O procedimento administrativo também se apresenta como modo de garantir a impessoalidade no agir da administração pública, na medida em que o registro e publicidade dos atos praticados permite que se busque a desconstituição de atos eventualmente viciados.

Como se vê, o princípio da igualdade, impessoalidade ou imparcialidade manifestase de diversas maneiras no processo administrativo. Em síntese, tais princípios visam garantir que o processo se desenvolva de forma objetiva e em igualdade de condições entre os conselheiros, inclusive por meio de ações positivas ou discriminatórias em favor dos conselheiros da sociedade civil em relação aos representantes do poder público. 


\subsubsection{Princípio do inquisitório, impulso oficial ou da oficialidade}

O princípio do inquisitório, impulso oficial ou da oficialidade significa que o andamento do procedimento administrativo é de responsabilidade da Administração Pública lato sensu, ou seja, enquadrando-se no gênero agente público, entendemos que a condução do processo caberá tanto aos conselheiros representantes do governo quanto da sociedade civil (BANDEIRA DE MELLO, 2014; DI PIETRO, 2014).

O referido princípio encontra-se previsto na Lei $\mathrm{n}^{\circ}$ 9.784/99 em diversos dispositivos legais, especialmente, para os atos de instauração (art. $5^{\circ}$ ), instrução probatória (art. 29) ou revisão de atos irregulares (art. 63, $\S 2^{\circ}$ ).

Outro aspecto importante do princípio do impulso oficial diz respeito à necessidade de previsão de prazos para cada uma das fases do procedimento. Desse modo, ainda que os conselheiros (particulares, servidores e órgãos públicos interessados) sejam omissivos, o procedimento deve chegar ao seu fim, ainda que por arquivamento dos autos (MEDAUAR, 2014).

Se, no processo judicial, o juiz está impedido de requerer oficiosamente a produção de provas, no processo administrativo, em vista do princípio da oficialidade ou do impulso oficial, todos os conselheiros têm o direito de solicitar a instrução probatória e não apenas o conselheiro proponente GÁRCIA DE ENTERRIA; FERNÁNDEZ, 2014). Por se tratar de órgão colegiado, a deliberação final quanto à pertinência das provas, cabe à plenária do Conselho.

Como dito acima, nos Conselhos de Políticas Públicas, a responsabilidade pela condução do procedimento deve ser compartilhada entre os conselheiros, inclusive os representantes da sociedade civil; pois, como visto no primeiro capítulo, são considerados agentes públicos para todos os efeitos legais, sobretudo no que concerne à responsabilidade administrativa, civil e criminal por suas ações e omissões.

Portanto, a exemplo do Conselho Municipal de Direitos da Criança e do Adolescente de São Paulo (Resolução n ${ }^{\circ}$ 79/05), nada obsta que a função de presidência seja ocupada por representante da sociedade civil.

A partir do exposto, buscamos enfatizar a compatibilidade entre o princípio do inquisitório e a função de direção do procedimento pelos conselheiros representantes da sociedade civil, sobretudo para a função de presidência do Conselho. 


\subsubsection{Princípios do contraditório e da ampla defesa}

O exercício do princípio do contraditório significa a possibilidade de cada um dos interessados manifestarem seu próprio ponto de vista em relação aos argumentos, fatos e dados existentes no processo administrativo antes da decisão final (MEDAUAR, 2014).

Segundo Floriano de Azevedo Marques Neto (2004), houve quem considerasse que a garantia constitucional ao contraditório e à ampla defesa (art. $\left.5^{\circ}, \mathrm{LV}\right)$ não fosse aplicada aos processos internos da Administração, sob o pretexto de que não haveria litígio nem litigantes; porém, esclarece o autor: a “Administração só pode atuar nos termos da lei e para exclusivo atingimento do interesse público. Se é assim, há que seguir regras e ritos prédeterminados". No mesmo sentido, Odete Medauar (2006) ressalta que o processo administrativo envolvendo interesses coletivos ou difusos também requer o exercício do contraditório e ampla defesa dos interessados - v.g. conselheiros e associações representativas de interesses difusos ou coletivos. Portanto, não há dúvidas de que tais garantias se aplicam aos procedimentos administrativos dos Conselhos.

Com base no artigo 14 da Lei Municipal 14.141/06 - LPAM, poderão figurar como interessados nos processos administrativos dos Conselhos: a) os conselheiros; b) particulares ou grupos potencialmente afetados por uma decisão - por exemplo, reintegração de imóvel cuja posse esteja sob o domínio de famílias de baixa renda; c) associações representativas na defesa de interesses difusos e coletivos em vista da natureza do objeto discutido nos Conselhos (políticas públicas).

Identificados os interessados, estes deverão ser notificados a respeito do início do processo, da pretensão, dos fundamentos e a respeito dos documentos que embasem proposta de política pública. Por simetria, aos demais conselheiros deve ser facultada a apresentação de alegações escritas, solicitação de provas e juntada de documentos em prazo determinado, o que pressupõe o direito de vista, de obtenção de certidões ou de cópias dos autos, com antecedência razoável da sessão deliberativa.

Em outras palavras, "aí se incluem o direito paritário de propor provas (com razoabilidade) e o direito a um prazo suficiente para o preparo das observações a serem contrapostas" (MEDAUAR, 2006, p. 112). Ao interessado também deverá ser garantido "o direito de audiência, em sentido literal ou estrito, [o qual] consiste no direito de falar oralmente, para relatar fatos, de viva voz, ou dar explicações sobre dados que são expostos" (MEDAUAR, 2006, p. 126, comentário nosso). 
Por fim, o exercício do contraditório e da ampla defesa visa tornar a gestão pública transparente; informar os interessados e possibilitar a apresentação de informações e provas sob pontos de vista diversos, objetivamente demonstradas nos autos (MEDAUAR, 2006).

\subsubsection{Princípio da motivação ou da fundamentação}

Pelo princípio da motivação ou da fundamentação, os Conselhos de Políticas Públicas se veem obrigados a explicitar as razões fáticas e jurídicas de suas decisões a fim de possibilitar seu efetivo controle político e também jurisdicional quando desarrazoados, desproporcionais ou contrários à ordem jurídica (BANDEIRA DE MELLO, 2014).

A motivação também serve para se apurar se a decisão final guarda compatibilidade com as informações objetivamente colhidas no decorrer da instrução do procedimento, especialmente, aquelas oriundas da participação procedimental. Trata-se de requisito essencial para o controle da legalidade e da legitimidade da decisão colegiada.

Conforme expõe Maria Sylvia Zanella Di Pietro, "sua obrigatoriedade se justifica em qualquer tipo de ato, porque se trata de formalidade necessária para permitir o controle de legalidade dos atos administrativos" (DI PIETRO, 2014, p. 81-82) ${ }^{26}$.

Embora a lei de processo administrativo federal faça referência a direitos ou interesses individuais (art. $2^{\circ}$, parágrafo único, inciso VII), não se podem concluir que as decisões de interesse geral tomadas pelo Conselho não devam ser motivadas. Pelo contrário, a motivação é princípio que informa qualquer decisão tomada em um Estado que se pressupõe republicano e democrático de direito (art. $1^{\circ}$, caput, $\mathrm{CF} / 88$ ).

A obrigatoriedade de fundamentação e motivação da decisão colegiada mostra-se essencial para o controle social e judicial das decisões tomadas pelo Conselho, de modo a afastar decisões subjetivas sem lastro nos elementos objetivamente produzidos no curso do procedimento.

\footnotetext{
${ }^{26}$ Não à toa, a Constituição Federal (art. 93 e 129, §4º, a Constituição Estadual de São Paulo (art. 111), as leis de processo administrativo federal (art. $2^{\circ}$, caput, da Lei Federal 9.784/99), estadual paulista (art. $9^{\circ}$, da Lei Estadual 10.177/98) e paulistana (art. 33, parágrafo único, da Lei Municipal 14.141/06) preveem expressamente que a Administração Pública deve indicar os pressupostos de fato e de direito de suas decisões.
} 


\subsection{ETAPAS DO PROCEDIMENTO ADMINISTRATIVO NOS CONSELHOS}

Cada Conselho tem sua própria dinâmica de funcionamento, daí não ser possível apresentar um único modelo de procedimento administrativo aplicável a todos os casos. No entanto, independentemente da forma, ordem e sucessão de atos nos procedimentos de cada Conselho, a doutrina indica a existência de três etapas elementares em todo procedimento administrativo - instauração, instrução e decisão (GÁRCIA DE ENTERRIA; FERNÁNDEZ, 2014; MEDAUAR, 2008; FERRAZ; DALLARI, 2012).

\subsubsection{Instauração}

$\mathrm{O}$ procedimento administrativo se instaura de ofício ou a requerimento do interessado. No âmbito do Conselho, a instauração poderá advir de determinação legal, ou mediante requerimento de um ou mais conselheiros, ou, ainda, de terceiro interessado nas hipóteses, forma e modo previstos em lei ou regulamento (FERRAZ, DALLARI, 2012; MEDAUAR, 2014).

A condição de parte para dar início ao procedimento deve ser prevista em lei ou regulamento. Pela ausência de interesses privados, o termo "parte" não pode ser tomado na acepção de polos contrapostos ou em litígio. Ainda que não concordem entre si - o que é natural e esperado em um Conselho de Políticas Públicas, os diversos conselheiros devem ser considerados colaboradores entre si. O objetivo perseguido deve ser a consecução do interesse público, o que não impede a defesa de uma posição que beneficie direta ou indiretamente determinado segmento social (mercado, sociedade civil e movimentos populares), ressalvadas as hipóteses de impedimento e suspeição dos conselheiros previstas em lei. ${ }^{27}$

Não há dúvidas de que o poder de decisão cabe somente aos conselheiros, mas é preciso saber se os cidadãos ou entidades representativas em geral possuem legitimidade

\footnotetext{
${ }^{27}$ A legitimidade a que se faz referência não impede nem limita o exercício de nenhum direito constitucional, como, por exemplo, o direito de petição aos Poderes Públicos em defesa de direitos ou contra ilegalidade ou abuso de poder; nem o direito de obter certidões em repartições públicas, para defesa de direitos e esclarecimento de situações de interesse pessoal (CF, art. $5^{\circ}, \mathrm{XXXIV}$, a e b); o direito à informação nos termos da Lei Federal 12.527/2011 etc.
} 
para instaurar ou intervir no procedimento administrativo do Conselho. Tendo como objeto apenas interesses difusos (políticas públicas), em regra, a instauração caberá somente aos conselheiros, salvo previsão em contrário na lei criadora ou no respectivo regimento interno.

No entanto, serão legitimados para participar do procedimento aqueles que, sem terem iniciado o processo, têm direitos ou interesses que possam ser afetados pela decisão a ser proferida, consoante o disposto no artigo 14, inciso II, da Lei de Processo Administrativo Paulistana $^{28}$. Por isso, a legitimidade para instauração deve ser prevista em lei, enquanto a intervenção para defesa de direitos ou interesses é uma garantia dos cidadãos (na defesa de direitos ou interesses privados eventualmente afetados) e das entidades ou organizações representativas de interesses difusos e coletivos.

Como elementos mínimos do requerimento, deverá constar a indicação do órgão, entidade ou autoridade responsável para conhecer do pedido; a identificação e qualificação do interessado; exposição dos fatos e seus fundamentos, formulação do pedido e data e assinatura do conselheiro requerente. Em vista do caráter instrutório do processo, não se deve exigir, desde então, provas que caibam a terceiros e que a parte não tenha condições de apresentar no momento da propositura (FERRAZ; DALLARI, 2012).

Ainda que existam falhas estruturais (formais) no requerimento, a Administração não pode se recusar a recebê-lo, nem pode rejeitar o pedido sem a oportunidade de o interessado o corrigir. Neste caso, caberá à Administração orientar o conselheiro (mas sem adentrar no mérito substancial do pedido - senão estaria infringindo o dever de imparcialidade), indicando minuciosamente os pontos que requerem reformulação em homenagem aos princípios da boa-fé e do devido processo legal. Apenas quando houver a reiteração de erros formais no mesmo pedido, a autoridade poderá indeferi-lo liminarmente (jamais recusar seu recebimento ou protocolo), mas sempre de forma motivada e passível de recurso, garantido o recurso administrativo à plenária do Conselho. A mesma regra aplicase às intervenções posteriores dos interessados, inclusive em relação à solicitação de provas, nas fases subsequentes do processo (FERRAZ; DALLARI, 2012).

Especialmente no caso dos Conselhos, em cuja composição podem se encontrar pessoas de instrução escolar deficiente, a exemplo dos representantes dos movimentos populares ou associações da sociedade civil organizada, deve ser garantida a formulação de requerimento ou intervenção processual oral. Não pode a Administração simplesmente a desconsiderar - o que violaria o direito de petição e o direito ao livre acesso ao procedimento

${ }^{28}$ No mesmo sentido, cf. art. $9^{\circ}$, inciso II, da Lei Federal 9.784/99 - LPAF. 
administrativo. No entanto, o pedido oral deverá ser reduzido a termo pela autoridade, a fim de cumprir os requisitos formais da instauração. O mesmo auxílio deverá ser ofertado aos conselheiros quanto aos atos processuais eventualmente realizados por meio informatizado, o qual não poderá servir de obstáculo ao acesso e manifestação de pessoas menos afeitas à tecnologia da informação. Para estes deverão existir meios alternativos à informatização, assim como se deve garantir que as constantes "falhas no sistema" não inviabilizem o acesso dos interessados ao processo (FERRAZ; DALLARI, 2012).

O pedido formulado deverá ser determinado e certo - o que não afasta a possibilidade de apresentá-lo sob a modalidade alternativa ou sucessiva, ou seja, não há problemas de se requerer o acolhimento de um ou outro pedido qualquer; como também pleitear o deferimento de um segundo pedido na impossibilidade do primeiro. Também não há óbice, salvo previsão legal em contrário, para a reunião de processos com propostas de políticas públicas conexas ou assemelhadas, formando-se um processo único, seguindo-se, analogicamente, as regras do processo judicial inclusas nos artigos 282 e seguintes do Código de Processo Civil (Lei 5.869/73) ou norma correlata ${ }^{29}$.

A alteração do pedido no curso do procedimento administrativo nos Conselhos não deve seguir a rigidez do processo jurisdicional nem dos processos administrativos para a defesa de interesses individuais, pois seu objeto é um interesse difuso. Portanto, caso o requerente identifique inconsistências ou inconveniências em sua proposição, não deve haver empecilho para sua alteração no curso do procedimento. Devem ser observados os princípios da economia processual, interesse público e do devido procedimento legal ou do formalismo moderado ${ }^{30}$. Aliás, não se pode perder de vista a natureza instrumental do processo, cujos atos procedimentais devem satisfazer o interesse público, daí a necessidade de sua flexibilização. Caso o requerente desista do pedido e a plenária do Conselho entenda conveniente sua continuidade, o processo terá seguimento até sua conclusão, pois o interesse individual não poderá sobrepor o interesse da coletividade representada.

Ademais, tratando-se de políticas públicas, a alteração da proposição é inerente ao processo de planejamento, eis que o pedido inicial não deve ter a pretensão de se apresentar

\footnotetext{
${ }^{29}$ No tocante à possibilidade de aplicação analógica das normas de processo jurisdicional cível, Sérgio Ferraz e Adilson Abreu Dallari ressaltam que: "Aqui, como nos demais capítulos que seguirão, frequentes serão as invocações ao processo jurisdicional (civil). E isso se apresenta duplamente justificado: - A teoria do processo é cientificamente uma, independentemente do ambiente estatal onde deva ele realizar-se. - O diploma maior de sobre direito, a Lei de Introdução às Normas do Direito Brasileiro, em seu art. $4^{\circ}$, fortemente recomenda o socorro subsidiário, ora abraçado" (FERRAZ; DALLARI, 2012, p. 141). Acompanhamos o entendimento dos autores mencionados, sobretudo por se tratar de pesquisa de cunho acadêmico e científico, atentando-se mais aos fatos e fundamentos jurídicos do que a certo ou qual diploma jurídico.

${ }^{30}$ Vide tópico 3.3.1 Princípio do devido processo legal ou do formalismo moderado.
} 
pronto e acabado. Muito pelo contrário, o procedimento serve justamente para que a proposta inicial seja aperfeiçoada coletivamente (FERRAZ; DALLARI, 2012). O requerimento esboça o problema ou agenda governamental sobre a qual a proposta de política pública pretende resolver, portanto, não se aplica ao caso dos Conselhos a máxima que veda a decisão "extra-petita" ou "citra-petita".

As despesas do processo, em regra, deverão ser suportadas pela Administração, com dotações orçamentárias destinadas especialmente à manutenção das atividades do Conselho. Em regra, não se deve cobrar taxa ou emolumento dos conselheiros, pois a instauração de requerimentos é exercício regular de sua função pública.

As proposições, após protocolizadas, deverão ser autuadas pela autoridade competente a fim de propiciar a racional gestão documental, a proteção dos documentos, facilitar o acesso dos autos pelos conselheiros etc. - como instrumento de apoio à administração, à cultura, ao desenvolvimento científico e como elementos de prova e informação dos interessados e da sociedade em geral, com observância das regras inerentes ao sigilo ${ }^{31}$.

Após a autuação do processo, os interessados deverão ser notificados sobre o início do procedimento e sobre o conteúdo do requerimento a fim de lhes possibilitar o exercício das garantias constitucionais do contraditório e da ampla defesa, isto é, facultando-lhes a apresentação de alegações escritas, solicitação de provas e juntada de documentos em prazo determinado, o que pressupõe o direito de vista, de obtenção de certidões ou de cópias dos autos, com antecedência razoável da sessão deliberativa.

\subsubsection{Instrução}

Independentemente da forma, ordem e sucessão dos atos procedimentais nos diversos Conselhos, a etapa de instrução pressupõe a possibilidade: a) de manifestação individual dos interessados sobre o conteúdo do requerimento; b) de solicitar informações a outros órgãos da Administração Pública; c) de realizar diligências, vistorias, estudos e laudos técnicos com a finalidade de habilitar os conselheiros a proferirem suas decisões de forma

${ }^{31}$ Assim dispõe a Política Nacional de Arquivos Públicos e Privados instituída pela Lei Federal n ${ }^{\circ} 8.159$, de 8 de janeiro de 1991, de âmbito nacional, regulamentada pelo Decreto no 4.073, de 3 de janeiro de 2002. 
objetiva, transparente e fundamentada, pois, em face das disposições constitucionais vigentes, a decisão não poderá ser considerada válida se não corresponder à realidade objetivamente demonstrada nos autos do processo administrativo (MEDAUAR, 2014).

Para o exercício dessas garantias, os interessados poderão ter vista dos autos, obter cópias de documentos neles contidos em qualquer momento do processo, formular alegações, apresentar documentos e solicitar a produção de provas no prazo de manifestação (FERRAZ; DALLARI, 2012).

Nos Conselhos, é comum a constituição de Comissões ou Grupos de Trabalho, permanentes ou temporários, incumbidos de realizar pesquisas, estudos, análises, proposições, elaboração ou acompanhamento de assuntos relevantes do órgão, cabendo, ao final, à respectiva Comissão ou Grupo de Trabalho a elaboração de relatório ou parecer final a ser apresentado ao órgão pleno do Conselho para deliberação.

Com efeito, visando à elaboração de uma política pública eficiente, "impende ao poder público dignificar a fase instrutória dos procedimentos a elas correspondentes, inclusive ampliando as possibilidades de fornecer e angariar informações úteis, fator essencial ao correto desempenho da função administrativa” (OLIVEIRA, 2010, p. 27).

Considerar o processo em sentido amplo torna recomendável examinar mais de perto o problema do contraditório. Contraditório é a noção jurídica que sintetiza a contraposição de interesses mediada pelo direito, da qual resulta a decisão, ideia-síntese do conflito regrado e institucionalmente processado. No sentido da lógica clássica, a noção de contraditório está ligada à ideia de dialética, à expressão dos contrários e à contraposição regrada de opiniões (BUCCI, 2013, p. 135).

Não por acaso, é na fase instrutória que se consagram os princípios da igualdade, impessoalidade, do contraditório e da ampla defesa de todos os interessados, conselheiros e demais legitimados. Nesse sentido, aos intervenientes no procedimento administrativo deve ser assegurada verdadeira "paridade de armas", ou seja, eventuais assimetrias funcionais e materiais entre os participantes devem ser compensadas por meio de arranjos e garantias jurídico-procedimentais ${ }^{32}$.

\footnotetext{
${ }^{32}$ Ao reconhecer a inevitável assimetria material entre os sujeitos que participam no processo, Maria Paula Dallari Bucci ressalta: “Considerando que há uma assimetria de informação e de posições dos vários interesses envolvidos, muitas vezes o desafio institucional reside em definir procedimentos que tornem o processo de decisão permeável aos interesses sociais dispersos, não necessariamente por meio da participação direta. As formas representativas podem eventualmente ser mais fiéis à presença da multiplicidade de interesses no cenário decisório do que a participação direta, que, do ponto de vista prático, na sociedade em geral, é seletiva, em virtude de assimetrias de meios de participação (recursos para deslocamento, presença em reuniões, contratação de especialistas para elaborar aspectos técnicos dos processos e assim por diante). É possível conceber procedimentos estatais de compensação das assimetrias - é o caso, por exemplo, de apoio à
} 
Por força do princípio da oficialidade, a função de instrução do procedimento caberá tanto aos conselheiros representantes do governo quanto os representantes da sociedade civil. Isto porque os conselheiros da sociedade civil se enquadram como agentes públicos para todos os efeitos legais, inclusive para fins de responsabilidade administrativa, civil e criminal por suas ações e omissões.

O tempo é variável essencial do procedimento administrativo, sendo-lhe pressuposta a sucessão de atos, cada qual dotado de finalidade e prazos específicos para sua conclusão. Em síntese, deve-se considerar que "existe o tempo interno ao processo, isto é, o fluxo de prazo que decorre na passagem de um elo da cadeia de atos para o seguinte. [...] não significa o transcurso de dias ou semanas, mas as mudanças de estado associadas à ocorrência de determinados fatos" (BUCCI, 2013, p. 142-143). Sobre a questão temporal, deve-se atentar que os prazos internos e os arranjos procedimentais dos Conselhos devem guardar sintonia com os prazos do processo orçamentário municipal ${ }^{33}$.

Neste aspecto, considerando a imprescindível articulação e coordenação entre os órgãos envolvidos (órgão central, órgãos setoriais e unidades orçamentárias) no processo orçamentário do município ${ }^{34}$, poderá haver reunião conjunta, com a participação de titulares ou representantes dos órgãos competentes conforme prevê o artigo 29 da LPAM e artigo 35 da LPAF.

A doutrina chama este instrumento de coordenação e articulação entre os órgãos competentes, de "reunião de serviços" ou "conferência de serviços" (confereza di servici), a qual:

Visa à composição de pluralidade de interesses públicos, envolvidos em procedimentos complexos (ex.: tutela ambiental, paisagístico-territorial, de saúde pública etc.), por meio da reunião transversal de procedimentos conexos, visando proporcionar celeridade e concentração decisória. Tratase de instrumento facultativo, de caráter instrutório ou decisório, neste último visando decisões "poliestruturadas". Tem cabimento nas situações em que o ato depende da manifestação de outros órgãos da Administração Pública [...]. Do ponto de vista procedimental e processual, os aspectos mais relevantes da conferência de serviços decorrem de ser um "modo para tornar colegial como norma o agir administrativo e, portanto, compensar o policentrismo organizacional com a unidade da decisão" (BUCCI, 2013, p. 157).

participação de entidades de defesa do consumidor em agências reguladoras -, mas isso não significa que eles devam, necessariamente, ser generalizados" (BUCCI, 2013, p. 141).

${ }^{33}$ Cf. 4.5 Instrumentos de planejamento urbano e orçamento municipal de São Paulo.

34 Cf. 4.3. Conselhos e processo orçamentário segundo a Lei Orgânica Municipal de São Paulo e, principalmente, 4.5.4 Normas procedimentais. 
Nesse sentido, não há dúvidas de que o processo orçamentário municipal depende da articulação administrativa entre as diversas Secretariais de Governo e os Conselhos de Políticas Públicas competentes. Daí a importância de a Administração se valer de mecanismos de coordenação, articulação e mediação, a exemplo das conferências de serviço, para conciliar os interesses públicos envolvidos ${ }^{35}$. Para esse fim, é necessária a previsão legal do feixe de competências de cada órgão, evitando tanto a sobreposição quanto o esvaziamento de competências entre os órgãos, especialmente no caso dos Conselhos de Políticas Públicas.

A fim de conferir maior legitimidade à decisão, a fase de instrução poderá contar ainda com a realização de consultas ou audiências públicas com a participação da sociedade em geral, possibilitando a manifestação de interesses públicos não representados no Conselho.

Para Gustavo Justino de Oliveira (2010), por meio das audiências públicas efetivase o direito fundamental dos cidadãos de opinarem, de modo eficaz e permanente, nos assuntos que interessem à coletividade. $\mathrm{O}$ autor ressalta ainda o duplo efeito informativo das audiências públicas. Ao mesmo tempo em que efetivam os princípios da publicidade e transparência, tornando públicas as orientações e diretrizes internas dos órgãos administrativos; as audiências públicas possibilitam a obtenção de informações por parte dos cidadãos até então desconhecidas da Administração, favorecendo a tomada de decisões mais próximas da realidade, ou seja, dos problemas e anseios concretos da sociedade. Deste modo, a audiência pública possibilita a efetivação do direito à informação (CF, art. 5º XXXIII) e o exercício das garantias constitucionais do contraditório e da ampla defesa (CF, art. $\left.5^{\circ}, \mathrm{LV}\right)$ no processo de elaboração de políticas públicas.

Aliás, segundo a Lei de Responsabilidade Fiscal ${ }^{36}$ e o Estatuto da Cidade $^{37}$, a realização de audiências públicas é obrigatória no processo de elaboração do PPA, LDO e LOA. Portanto, quando os Conselhos tenham recebido competência legal para esse fim, a realização de audiências será obrigatória. Nesses casos, deve ficar claro que as audiências

\footnotetext{
${ }^{35}$ No mesmo sentido caminha a proposta do anteprojeto da Reforma da Organização Administrativa Brasileira, formulada por comissão de especialistas e constituída pelo Governo Federal. Sua Seção II cuida especialmente da Articulação Administrativa, a qual se subdivide em funções de coordenação e supervisão. Nos termos do artigo 38, "a articulação administrativa dá-se por meio da coordenação e da supervisão e visa à eficácia, à eficiência e à compatibilização da atuação dos agentes, órgãos e entidades estatais com as políticas públicas, o planejamento e as diretrizes governamentais". Já o artigo 39 dispõe que "a coordenação e supervisão têm por objetivo assegurar a uniformidade, a racionalidade e a coesão política no exercício de competências dos diferentes órgãos e entidades estatais, bem como no relacionamento com as entidades paraestatais e com as entidades não estatais" (MODESTO, 2010, p. 431).

36 Lei Complementar Federal 101/00, inciso I do art. 48.

${ }^{37}$ Lei Federal 10.257/01, art. $2^{\circ}$, caput e incisos I, II e IV; art. $4^{\circ}$, inciso II, “f”; art. 44.
} 
públicas realizadas obrigatoriamente pelos Conselhos não se confundem com as audiências realizadas obrigatoriamente pelo Poder Executivo ${ }^{38}$, pois se referem a parcelas de recursos e despesas distintas do orçamento. Por exemplo, o CMH deverá realizar audiências públicas sobre a proposta orçamentária setorial do FMH, enquanto o Poder Executivo realizará audiências públicas sobre outros capítulos da proposta orçamentária municipal de São Paulo. Certo é que, em ambos os casos, "a realização da audiência pública será condição de validade do processo administrativo em que está inserida. Caso não implementada, ao arrepio da determinação legal, o processo estará viciado, e a decisão administrativa correspondente será inválida" (OLIVEIRA, 2010, p. 29).

Marcos Augusto Perez (2008) esclarece que as audiências públicas se caracterizam pela realização de sessões de acesso público e gratuito, com destaque para a realização de debates orais. Cabe à Administração disponibilizar, por meios acessíveis à população, informações, minutas de propostas e/ou documentos essenciais ao subsídio dos debates. No mesmo ato ou em audiência devolutiva, a Administração tem o dever de responder aos questionamentos da sociedade, bem como explicitar as razões de acolhimento ou não das sugestões apresentadas.

Mas não só. As audiências públicas poderão ainda se destinar à prestação de contas à sociedade, sem finalidade instrutória ou função acessória a outro procedimento. Nesse caso, é o Conselho, como órgão, e os conselheiros, individualmente, que devem prestar contas de suas atividades, dando publicidade à aplicação dos recursos públicos, indicando as ações financiadas, seus custos, abrangência, número de atendidos e indicadores qualitativos.

Nesse sentido, a Resolução $n^{\circ} 70 / 03^{39}$ do Conselho Municipal da Criança e do Adolescente de São Paulo (CMDCA/SP), que dispõe sobre a aplicação dos recursos do FUMCAD, prevê que:

Art. $3^{\circ}[\ldots] \S 3^{\circ}-$ Semestralmente, o CMDCA/SP, juntamente com as organizações responsáveis pela execução, supervisão e acompanhamento

\footnotetext{
38 A respeito da obrigatoriedade de realização de audiências públicas pelo Poder Executivo na fase de elaboração das peças orçamentárias (PPA, LDO e LOA), segundo Fábio Gomes dos Santos há duas interpretações sobre a obrigatoriedade de realização de audiências públicas na fase de elaboração da proposta orçamentária inclusive pelo Poder Executivo ou somente pelo Poder Legislativo. Segundo o autor, o artigo 44 do Estatuto da Cidade poderia levar a três interpretações distintas: a) haveria quem entendesse que as audiências do orçamento seriam obrigatórias apenas na fase de elaboração da proposta orçamentária pelo Poder Executivo; b) outra corrente entende que as audiências seriam obrigatórias tão somente na fase de discussão da proposta orçamentária na Câmara Municipal; c) a terceira, a mais correta em seu entendimento, entende que a lei exige a realização tanto na fase de elaboração da proposta pelo Executivo quanto na fase de discussão pelo Legislativo (SANTOS, 2013, p. 83).

${ }^{39}$ Resolução n ${ }^{\circ}$ 70/03 do Conselho Municipal dos Direitos da Criança e do Adolescente - CMDCA. Diário Oficial da Cidade de São Paulo. Poder Executivo. São Paulo, 09 out. 03, p.53-54.
} 
dos projetos, realizará audiência pública de prestação de contas e dará publicidade, inclusive por outros meios, da aplicação dos recursos do FUMCAD/SP, indicando as ações financiadas (seus custos, abrangência, número de atendidos e indicadores qualitativos) e o montante doado ao FUMCAD/SP.

Por meio de audiências públicas desta natureza, concretizam-se os princípios da transparência, da publicidade e de prestação de contas à sociedade. Abre-se a atividade interna do Conselho ao controle social, servindo para compensar o déficit de legitimidade inerente a toda representação política (AUAD, 2007).

Como visto, a legitimidade da representação política dos conselheiros passa a depender da adoção de mecanismos de controle e prestação de contas à sociedade em geral, cuja previsão deve obrigatoriamente constar dos regimentos internos dos Conselhos.

$\mathrm{Na}$ consulta pública, assim como na audiência pública, o Conselho deve disponibilizar uma minuta de proposta ao conhecimento público, por um prazo determinado, e cujas opiniões, sugestões ou reclamações deverão ser entregues por meio escrito. Tal como no caso da audiência pública, o órgão deverá considerar as manifestações da sociedade antes ou simultaneamente à decisão final. A resposta da Administração poderá ser comum para todas as questões que sejam substancialmente iguais (PEREZ, 2004).

Regra geral, a participação de pessoas em audiências e consultas públicas não confere a qualidade de interessado, por si só, para atuar no procedimento administrativo do qual originou. Esta é a dicção dos artigos $28, \S 2^{\circ}$ da LPAE e do art. $31, \S 2^{\circ}$ da LPAF, entendimento que é acompanhado pela doutrina majoritária (FERRAZ; DALLARI, 2012; GÁRCIA DE ENTERRIA; FERNÁNDEZ, 2014).

Devemos salientar, ainda, que os autos do processo administrativo devem, em regra, permanecer na sede do órgão encarregado da instrução, cujos atos devem ali ser produzidos. Excepcionalmente, tal como ocorre nas audiências públicas, os atos externos devem ser remetidos à sede para juntada aos autos. Desta forma, a autoridade competente mantém o controle sobre o andamento do processo, evitando sua paralisação ou extravio dos autos (FERRAZ; DALLARI, 2012).

Nesse sentido, os atos instrutórios deverão ser anexados ao processo administrativo em ordem cronológica, sendo numerados e rubricados pela autoridade competente, a partir da autuação do requerimento inicial. Por último, os interessados terão o direito de tomar ciência e vista do processo após a conclusão da etapa de instrução a fim de apresentar considerações ou alegações finais, orais ou escritas, antes que a proposta de decisão tenha 
sido redigida, direito sem o qual não se poderá falar em processo em sentido jurídico (GÁRCIA DE ENTERRIA; FERNÁNDEZ, 2014).

Como se vê, a etapa de instrução nos Conselhos objetiva, primeiro, a colheita de informações sobre determinada proposta de política pública, num certo espaço de tempo; segundo, o exercício do contraditório e ampla defesa por parte dos interessados sobre o conteúdo anexado aos autos. Percorridas as etapas de instauração e instrução, podemos dizer que o Conselho estará em condições de proferir uma decisão final à proposição de política pública, cujos requisitos serão comentados a seguir.

\subsubsection{Decisão}

A decisão administrativa, analogicamente ao disposto no artigo 458 do Código de Processo Civil - CPC, possui elementos estruturais intrínsecos: relatório, motivação e a parte dispositiva. A aplicação subsidiária do referido diploma legal não é opção doutrinária ou legislativa: decorre dos postulados e garantias constitucionais inerentes ao processo administrativo (FERRAZ; DALLARI, 2012).

Em órgãos colegiais, como cumprir os requisitos intrínsecos do relatório e da motivação em vista da pluralidade de sujeitos? Nesse caso, não vemos outra solução senão adotar o processo judicial como paradigma ${ }^{40}$, segundo o qual a decisão ou voto deve ser formulado por um relator e submetido à apreciação coletiva. Em caso de discordância entre os legitimados a sessão deve ser suspensa e reiniciada na reunião imediatamente seguinte, em que cada qual deve apresentar seu próprio voto, submetendo-os individualmente à apreciação do órgão colegiado ${ }^{41}$.

O relatório da decisão consiste na exposição (sucinta, mas precisa) dos elementos

\footnotetext{
${ }^{40}$ Cf. CPC: "Art. 555. No julgamento de apelação ou de agravo, a decisão será tomada, na câmara ou turma, pelo voto de 3 (três) juízes" (Redação dada pela Lei n 10.352, de 26.12.2001); “Art. 556. Proferidos os votos, o presidente anunciará o resultado do julgamento, designando para redigir o acórdão o relator, ou, se este for vencido, o autor do primeiro voto vencedor".

${ }^{41}$ Nesse sentido, dispõe o Regimento Interno do Conselho Municipal de Saúde de São Paulo prevê que: "Art. 14. As Reuniões do Conselho Municipal de Saúde, observada a legislação vigente, terão as seguintes rotinas para ordenamento de seus trabalhos: [...] II - Ao início da discussão poderá ser pedido vistas, devendo o assunto retornar impreterivelmente, na reunião ordinária seguinte para apreciação e votação, mesmo que este direito seja exercido por mais de 01 Conselheiro. O Conselheiro que pediu vistas será o relator, no caso de mais de um conselheiro pedir vistas, haverá tantos relatores quanto os pedidos de vista. Todo pedido de vista deve corresponder a um parecer técnico, por escrito, previamente apresentado aos Conselheiros. Os pareceres deverão ser colocados em votação um a um, obedecida a ordem de solicitação de vistas".
} 
presentes nos autos, isto é, a descrição dos elementos que constituem o requerimento, as intervenções dos interessados e demais incidentes do processo. Nesse momento, o relator não deverá proferir seu juízo de valor, este deve ser reservado ao capítulo da fundamentação. Diferentemente do que se possa imaginar, o relatório não é peça decorativa. Ao contrário, exerce forte influência no direcionamento da decisão a ser tomada uma vez que a fundamentação da decisão deverá fazer remissão obrigatória aos elementos processuais constantes do relatório. Em complemento, Sérgio Ferraz e Adilson de Abreu Dallari advertem:

Peça dessa natureza, quando mal ou erradamente elaborada, pré-dirige a parte dispositiva para terrenos fatalmente equivocados. É claro que, a rigor, o que o interessado ataca é a decisão, em senso estrito. Porém, muita vez, para se reverter a decisão infeliz, imperioso será postular, da instância recursal, a própria reformatação dos seus pressupostos históricos e factuais - isto é, o relatório, por si, já configure lesividade, de regra, a instância recursal, se atender à solicitação em tela, operará nas duas dimensões: elaborará, para sua própria consideração, um relatório diferente e proporá a solução que dele pense dever decorrer. Mas isso apenas confirma a premissa anterior: o relatório, em si mesmo, vez por outra poderá sofrer impugnações autônomas de parte dos prejudicados por suas erronias (FERRAZ; DALLARI, 2012, p. 261).

Sendo assim, ainda que a decisão do Conselho seja soberana e irrecorrível, antes que a matéria seja colocada em votação, os conselheiros e interessados poderão suscitar questões prejudiciais ou preliminares a fim de corrigir vícios que possam acarretar a nulidade da decisão proferida ${ }^{42}$.

A etapa da motivação ou fundamentação da decisão concretiza o princípio da motivação ou fundamentação do procedimento administrativo, segundo o qual os Conselhos se veem obrigados a explicitar as razões fáticas e jurídicas de suas decisões a fim de possibilitar seu efetivo controle político e também jurisdicional nos casos que se mostrem desarrazoados, desproporcionais ou contrários à ordem jurídica (BANDEIRA DE MELLO, 2014).

Salvo previsão legal em contrário, tal como ocorre no processo judicial, a autoridade competente para decidir poderá avaliar as provas produzidas segundo seu livre convencimento, conferindo valor maior a uma prova que outra (GÁRCIA DE ENTERRIA; FERNÁNDEZ, 2014).

\footnotetext{
${ }^{42}$ Nesse sentido, o Regimento Interno do Conselho Gestor do Fundo Municipal de Desenvolvimento Urbano - FUNDURB, Resolução no 002/2011, dispõe que: "Artigo 14 - As questões preliminares ou prejudiciais serão discutidas e votadas antes da matéria principal”.
} 
Como explicitado anteriormente, a motivação também serve para se apurar se a decisão final guarda compatibilidade com as informações colhidas no decorrer da instrução do procedimento, especialmente, aquelas oriundas da participação procedimental. Trata-se de requisito essencial para o controle da legalidade como ainda da legitimidade da decisão colegiada. Assim, uma decisão sem motivação será decisão nula. ${ }^{43}$ Nesse sentido, vemos que a atividade discricionária do decisor encontra-se limitada, pois não poderá fazer alusão a fatos que não estejam anexados aos autos.

Por fim, o capítulo do dispositivo ou da decisão propriamente dita, deve guardar congruência com a fundamentação, ou seja, deverá traduzir a escolha política já anunciada logicamente na fundamentação entre as alternativas enunciadas objetivamente nos autos (GÁRCIA DE ENTERRIA; FERNÁNDEZ, 2014).

Neste capítulo procuramos abordar o regime jurídico dos procedimentos administrativos aplicáveis aos Conselhos, especialmente, os princípios jurídicos e etapas do procedimento interno de formulação de políticas públicas.

No capítulo seguinte, analisaremos os procedimentos externos de formulação de políticas públicas, isto é, os ciclos ou etapas de formação das políticas públicas, a expressão jurídica dos meios de articulação e coordenação entre os órgãos envolvidos no processo orçamentário, destacando, não apenas a importância de participação dos Conselhos, quanto sua obrigatoriedade. Em seguida, analisaremos cada um dos instrumentos legais de planejamento e orçamento (PDE, PPA, LDO e LOA) e as normas procedimentais de formulação das políticas públicas no município de São Paulo.

\footnotetext{
${ }^{43}$ Vide 3.3.5 Princípio da motivação ou da fundamentação.
} 


\section{A PARTICIPAÇÃO DOS CONSELHOS NO PROCESSO ORÇAMENTÁRIO MUNICIPAL DE SÃO PAULO}

O presente capítulo pretende analisar os fundamentos legais e políticos da participação dos Conselhos no processo orçamentário municipal de São Paulo, o qual representa o segundo objetivo geral da presente pesquisa.

A partir da abordagem do ciclo de formação das políticas públicas (policy cicle) a seguir, perceberemos que a presença de atores sociais ( stakeholders $^{44}$ ), envolvidos em todo o ciclo de formação das políticas públicas, na composição dos Conselhos Municipais de Políticas Públicas, qualifica-os como um lugar adequado para a formulação de políticas públicas.

Depois, analisaremos as políticas públicas na perspectiva jurídica, quando ficará clara a relação entre a formação das políticas públicas e o processo orçamentário municipal (PPA, LDO e LOA). Além da importância política vista acima, veremos que a participação dos Conselhos no processo orçamentário municipal é obrigatória segundo as disposições da Lei Orgânica Municipal de São Paulo. Estabelecidos estes pressupostos, iniciaremos a análise do regime financeiro do processo orçamentário aplicável aos Conselhos, seus princípios jurídicos, instrumentos legais de planejamento e orçamento e normas procedimentais. Por fim, analisaremos o regime financeiro dos Fundos Especiais, utilizados, com frequência, para financiar políticas públicas desenhadas pelos Conselhos, como é o caso do FMH.

\subsection{CICLO DE FORMAÇÃO DAS POLÍTICAS PÚBLICAS (POLICY CICLE)}

John W. Kingdon (2011) oferece uma metodologia de análise das políticas públicas a partir de seu ciclo de formação (policy cicle), correspondente às sucessivas etapas de

\footnotetext{
44 “A palavra 'parte interessada' é uma das possíveis traduções para a palavra stakeholders em português. Essa é a expressão que consta no guia PMBOK (PMI, 2013a) em sua versão na língua portuguesa. No Brasil, é comum também o uso de outras palavras para a tradução de stakeholder: "intervenientes", "afetados" ou "impactados". No guia $P M B O K$, a palavra stakeholder se refere a pessoas ou organizações ativamente envolvidas no projeto, que têm interesse no projeto ou que são afetados por ele", definição que se aplica adequadamente ao conceito de políticas públicas (VALLE et. all., 2014, p. 18).
} 
elaboração da política pública, descrita pelo autor em: a) etapa de identificação dos problemas; b) de definição da agenda; c) de formulação da política pública; d) de implementação e; e) avaliação.

A primeira fase do ciclo de formação das políticas públicas (policy cicle) corresponde ao levantamento das condições e realidades locais que carecem de serviços ou prestações públicas. Neste ponto, o Conselho oferece valiosos elementos para a percepção dos problemas sociais, pois a elegibilidade de um conselheiro é condicionada, em regra, à sua afinidade técnica ou prática com determinada política pública. Os movimentos populares são os próprios beneficiários que carecem da política pública, daí a importância de sua participação para o levantamento dos problemas que lhes são próximos. Os conselheiros da sociedade civil organizada, por sua vez, representam as entidades (ONGs, universidades, setor privado etc.) que atuam diretamente na área sobre a qual a política pública incidirá, podendo, por isso, contribuir com conhecimentos técnicos e científicos. Há também os conselheiros que representam o governo e que devem ser selecionados dentre os funcionários lotados nos setores da Administração diretamente envolvidos no planejamento ou implementação das referidas políticas públicas. Assim, os Conselhos se apresentam como espaço de discussão privilegiado no ciclo de formação da política pública.

Somado à expertise própria de seus membros, o funcionamento do Conselho pressupõe a realização de estudos técnicos, visitas de campo, permanente recebimento de demandas da população, bem como a realização de Audiências Públicas, Conferências Municipais ou Fóruns Temáticos periódicos com a participação aberta às demais entidades, movimentos sociais e comunidade em geral, com o objetivo de diagnosticar a situação social do município.

Como exemplo, Laura Amando de Barros ressalta: “outra importante ferramenta de orientação ao planejamento, na seara da infância e juventude, são as Conferências, tradicionais e lúdicas, que ocorrem em nível municipal, estadual e federal" (AMANDO DE BARROS, 2012, p. 295).

A etapa de identificação dos problemas se realiza por meio de diagnósticos, que identificam os problemas e os classificam a partir de indicadores. Os diagnósticos, por sua vez, concretizam-se pelos estudos técnicos ou por meio da realização de conferências municipais, audiências e consultas públicas.

A etapa seguinte de definição da agenda $^{45}$ procura responder, dentre outras

${ }^{45} \mathrm{O}$ termo agenda adotado no presente trabalho segue a definição de John W. Kingdon, segundo o qual: “A agenda, como eu a concebo, é a lista de temas ou problemas que são alvo, em dado momento, de séria atenção, 
questões, por que um problema é incluído na agenda de prioridades do governo e outro não. Para isso, John W. Kingdon (2011) propõe analisar a formulação das políticas públicas a partir da confluência de três fatores ou múltiplos fluxos, como prefere chamar.

No primeiro fluxo, dos problemas, o governo procura identificar e classificar os problemas de acordo com seu grau crítico. Primeiramente, cabe distinguir situações toleradas dos problemas propriamente ditos. Ao mesmo tempo em que determinadas situações, antes toleradas, podem se tornar problemas, certos problemas poderão passar a ser tolerados e deixar de receber atenção dos governantes. Situações que contrariam valores importantes da sociedade costumam se tornar problemas. Por sua vez, certas situações problemáticas poderão passar a ser toleradas enquanto o governo esteja ocupado na resolução de algum problema, ou porque os grupos de pressão se frustram nesse período e desistem de pressionar o governo, ou ainda porque se acostumam e dão outro rótulo à situação. Nesse processo, cada grupo de interesse usa de suas próprias e variadas estratégias a fim de sensibilizar os decisores (decision-makers) quanto à prioridade de situações qualificadas como problemas.

Kingdon (2011) descreve três elementos determinantes para a identificação dos problemas: indicadores, eventos-foco e avaliações. Os indicadores, como dito acima, servem para ressaltar a intensidade dos problemas, distinguindo-os em níveis de gravidade. Já os eventos-foco seriam acontecimentos extraordinários (naturais, sociais ou políticos) que colocam certa situação em foco, recebendo o nome de "janelas de políticas" (policy window) ou “janela de oportunidades". Nesse caso, os tomadores de decisão precisarão avaliar se os efeitos dos eventos são temporários ou permanentes e se essas situações poderão ser qualificadas como problemas. Estes também poderão ser comunicados às autoridades, formalmente, por meio de conferências municipais, consultas ou audiências públicas, exercício do direito de petição e representação ou, informalmente, pelos protestos, ocupações de prédios particulares ou públicos etc. Cada uma dessas estratégias ou eventos tem a capacidade de chamar a atenção das autoridades para situações qualificadas como problemáticas.

Um segundo fluxo, das soluções, corresponde ao encontro de soluções e alternativas

tanto da parte das autoridades governamentais como de fora do governo, mas estreitamente associadas às autoridades. No âmbito dos transportes, por exemplo, o secretário de Transportes e os membros dos comitês congressistas da jurisdição podem estar considerando, em um dado momento, uma variedade de problemas, tais como o custo de obras para o transporte de massas, a deterioração de estradas, as ineficiências geradas pela regulamentação econômica das empresas aéreas, ou vazamentos nos tanques de grandes navios nos portos do país. Dentro dos possíveis temas ou problemas aos quais os governantes poderiam dedicar sua atenção, eles se concentram em alguns e não em outros. Assim, o processo de estabelecimento da agenda reduz o conjunto de temas possíveis a um conjunto menor, que de fato se torna foco de atenção" (KINGDON, 2007, p. 222). 
viáveis aos problemas identificados. Destaca-se aqui o papel desempenhado pelos burocratas de carreira, pesquisadores, especialistas e acadêmicos em geral, cujo interesse em comum os aproxima ao ponto de conhecerem as ideias, propostas e atividades uns dos outros, razão pela qual Kingdon (2011) os chama de "comunidades políticas" ou "comunidades de especialistas". Esses participantes, relativamente invisíveis, atuam de forma mais ou menos coordenada por meio de mecanismos de persuasão, suas ideias são discutidas e divulgadas em congressos, projetos de lei, discursos, imprensa e conversas particulares. Quanto maior for o apoio das “comunidades políticas", maior será a chance de determinada ideia/solução ser acatada pelos agentes políticos e, consequentemente, certo problema entrar na agenda política.

Em derradeiro, o terceiro fluxo coincide com o processo político, exercendo forte influência as eleições, legislações ou o programa de governo recém-eleito. Estes seriam os "participantes visíveis" do processo de elaboração da política pública e que definem sua agenda, chefes do Poder Executivo, Legislativo e seus assessores de alto escalão. Considerando que os eventos políticos seguem dinâmicas e regras próprias, a inclusão de determinado problema na agenda política independe do "fluxo dos problemas" ou do "fluxo das soluções" citados acima, embora sirvam para justificar uma ou outra opção política. No âmbito político, o consenso não é formado pela persuasão dos argumentos, mas, sim, pela negociação e compartilhamento do poder. Por isso, quem tem maiores possibilidades de realizar as reivindicações de outros atores políticos possui maior capacidade de incluir os assuntos na agenda política de "cima para baixo". Desse modo, segundo o autor, a convergência dos "múltiplos fluxos" é o que justificaria a inserção de um problema na agenda política ao invés de outro (KINGDON, 2007).

Na etapa seguinte, a elaboração da política pública decorreria de um processo misto de planejamento e orçamento uma vez que o ciclo orçamentário, em tese, teria deixado de ter caráter meramente contábil, agregando mecanismos de planejamento de longo prazo em sua formação, tais como os instrumentos citados no parágrafo anterior (OLIVEIRA, 2008; GIACOMONI, 2012; CONTI, 2008).

Análises empíricas de políticas públicas têm revelado que os formuladores de políticas públicas atuam em um ambiente permeado de incertezas em vários níveis. Primeiramente, as políticas púbicas envolvem: a) fatores complexos relacionados aos fenômenos sociais e econômicos; b) escasso conhecimento sobre o tema; c) constrangimentos quanto ao tempo e aos recursos sobre os quais os formuladores operam. Segundo, porque os formuladores não controlam as condições e contingências que poderão 
afetar a política pública na fase de sua implementação, a qual abrirá espaço para novas decisões discricionárias do agente executor. Por isso, durante a etapa de elaboração mostrase importante a participação dos agentes públicos e privados responsáveis pela implementação da política pública (stake holders), que podem adiantar circunstâncias importantes para o sucesso da implementação futura do programa de ação (SILVA; MELO, 2000).

Nessa perspectiva, mostram-se importantes os mecanismos de coordenação e articulação interinstitucional para a formulação de políticas públicas em ambientes institucionais democráticos, descentralizados e com funções altamente especializadas. Já vimos que, na realidade, trata-se de aspectos mais gerais e que caracterizam o contexto da pós-reforma do Estado em que os mecanismos de elaboração e implementação passam por uma imbricada estrutura de governança (governance), no sentido de arranjos institucionais que dão sustentação à cooperação, coordenação e à negociação da política pública (DRUMOND; SILVEIRA; SILVA, 2014).

Conforme dito acima, Conselho é um órgão formado justamente pelos diversos atores sociais, públicos e privados, envolvidos em todo o ciclo da política pública - policy cicle, desde as etapas de percepção dos problemas, de definição da agenda, de elaboração, de execução e, por fim, de avaliação dos resultados da política pública.

Aliás, é justamente o reconhecimento da inexorável participação de atores nãoestatais no desenho das políticas públicas o que justifica e exige a complementação das instituições representativas com a representação/participação de todos os atores sociais, e não apenas daqueles que detém maior poder e já se relacionam de maneira constante e diversa com o Estado, a exemplo do mercado (poder econômico) (SÁNCHEZ MÓRON, $1980)^{46}$.

Interessante notar que a presença de representantes da supracitada "comunidade de especialistas" (ex.: ONGs e universidades) nos Conselhos, insere no órgão decisor mecanismos de persuasão/argumentação próprios dos fluxos dos problemas e das soluções, e não somente o instrumento de negociação próprio do fluxo político, descrito por Kingdon (2007). Assim, nos Conselhos, os diagnósticos e indicadores sociais ganham centralidade, conferindo à decisão política maior racionalidade reduzindo a discricionariedade na definição da política pública.

No entanto, como relatamos no primeiro capítulo ${ }^{47}$ e será aprofundado mais adiante,

\footnotetext{
${ }^{46}$ Para maiores detalhes, vide o tópico 2.1 A democracia participativa na atualidade.

${ }^{47}$ Vide 2.5 Os procedimentos administrativos e o processo orçamentário municipal: objetos de pesquisa.
} 
a operacionalização externa dos Conselhos em geral carecem de articulação e coordenação quanto ao processo orçamentário municipal. No próximo item, analisaremos as políticas públicas na perspectiva jurídica, quando ficará clara a relação entre a formação das políticas públicas e o processo orçamentário municipal (PPA, LDO e LOA).

\subsection{POLÍTICAS PÚBLICAS NA PERSPECTIVA JURÍDICA}

A política pública é objeto de estudo recente no campo do Direito, inclusive a doutrina jurídica questiona se haveria um conceito de políticas públicas exclusivamente jurídico por se tratar de matéria oriunda de outros campos do conhecimento, como a Ciência Política e a Administração Pública. No entanto, o Direito exerce função essencial no processo de formulação, implementação e avaliação dessas políticas públicas ao transformar as intenções políticas em normas jurídicas vinculativas, limita a discricionariedade da fase de implementação e oferece elementos objetivos para a fase de avaliação. Daí a importância de compreendê-las também sob a perspectiva do direito.

Eros Roberto Grau, criticando a evidente situação de divórcio entre o direito e as demais ciências sociais, ressalta que o tema do planejamento econômico não teve a atenção da doutrina jurídica brasileira até meados da década de 1980, com exceção de menções à literatura estrangeira (GRAU, 1978). Ressaltando a importância do direito para a política, Maria Paula Dallari Bucci adverte que a Ciência do Direito não só pode, como deve considerar as políticas públicas como objeto de pesquisa, sobretudo para que os valores inscritos democraticamente no ordenamento jurídico possam penetrá-las e conformá-las (BUCCI, 2006b).

Sob a perspectiva jurídica, as políticas públicas poderiam ser conceituadas como programas de ação governamental, formulados por meio de processos estruturalmente regulados pelo Estado e cuja implementação utiliza recursos à disposição do poder público ou da iniciativa privada - v.g. processo eleitoral, de planejamento, orçamentário, legislativo, administrativo e judicial (BUCCI, 2006b); ou, poderiam ser classificadas como normas definidoras de direitos e obrigações aos órgãos públicos envolvidos na implementação daqueles programas de ação (GRAU, 1978).

Nesse sentido, os instrumentos legais de planejamento e orçamento previstos no artigo 165 da Constituição Federal, o Plano Plurianual (PPA), a Lei de Diretrizes 
Orçamentárias (LDO) e a Lei Orçamentária Anual (LOA) “podem ser considerados as expressões jurídicas de políticas públicas, por excelência”. É por meio deles que a política econômico-financeira e o programa de trabalho do governo formalizam-se em diretrizes, objetivos e metas, criando direitos e obrigações para os órgãos públicos envolvidos na implementação dos programas de ação governamental (BUCCI, 2006b, p. 15-16).

A partir do conceito supracitado, sobressaem elementos de estruturação da política pública a seguir comentados: programa, ação-coordenação e processo (BUCCI, 2006).

Em relação às políticas públicas como processo, remetemos o leitor ao capítulo terceiro, onde o tema foi amplamente analisado ${ }^{48}$. Porém, cabe relembrar que o elemento do processo em contraditório se associa à abordagem jurídica inequívoca da dimensão participativa dos Conselhos Municipais de Políticas Públicas nos procedimentos de formulação de políticas públicas, embora careçam de operacionalização adequada (BUCCI, 2006b), o que demonstra a importância e atualidade deste trabalho.

O programa corresponde ao delineamento geral, e o conteúdo propriamente dito, da política pública. Por meio dele, individualizam-se a unidade de ação administrativa e os objetivos concretos da política; os elementos operacionais, instrumentais e procedimentais; bem como os indicadores exigidos para a avaliação da política pública, após sua implementação. A partir desses elementos, a definição prévia do programa (fase de elaboração) orienta a implementação da política pública (fase de execução) e, depois, torna possível que o programa seja avaliado e revisto (fase de avaliação), para então reiniciar o ciclo de formação da política pública (BUCCI, BUCCI, 2006b).

Abre-se um parêntese. Constata-se que a definição prévia do programa, na fase de elaboração, é essencial para a adequada implementação e avaliação da política pública. Isso será de grande utilidade para a compreensão do papel dos Conselhos Municipais de Políticas Públicas na elaboração e físcalização de políticas públicas e; de modo especial, para o entendimento das problemáticas levantadas nesta pesquisa em relação ao CMH. Fecha-se o parêntese.

Em relação à qualidade de ação-coordenação do programa, ressaltamos que os instrumentos de formalização da política pública (PPA, LDO e LOA) servem de meio de comunicação e coordenação entre os agentes, públicos e privados, envolvidos: a) Poderes Públicos, Executivo, Legislativo e Judiciário; b) entre os níveis federativos; c) no interior do Governo, entre as várias pastas; d) ou, ainda, entre organismos da sociedade civil e o Estado.

\footnotetext{
${ }^{48}$ Para maiores detalhes, ver capítulo 3 Regime jurídico dos procedimentos administrativos aplicáveis aos
} Conselhos. 
Por essa razão, quanto maior for a proximidade e coerência entre a formalização (leis orçamentárias) e o conteúdo material (programa) da política pública, maior será a efetividade jurídica e a possibilidade de que os resultados da política pública sejam alcançados. A isso se dá o nome de "modelagem jurídica" (BUCCI, 2006b).

Ainda que seja "plausível considerar que não haja um conceito jurídico de políticas públicas", cabe ao direito construir uma metodologia capaz de descrever, compreender e analisar as políticas públicas, a fim de traduzi-las em formas e processos jurídicos correspondentes (BUCCI, 2006b, p. 39 e 47).

Conclui-se que as políticas públicas, na perspectiva jurídica, se expressam por excelência nos instrumentos de formalização (PPA, LDO e LOA), cujo conteúdo vincula recursos públicos aos programas de ação: diretrizes, metas, objetivos, recursos disponíveis e indicadores de avaliação. Vimos que a definição clara e prévia dos programas de ação no PPA, LDO e LOA favorece tanto a coordenação administrativa, quanto a implementação e avaliação das políticas públicas. Por fim, adverte-se que, nas políticas públicas, a função do direito não se esgota na identificação da validade ou invalidade dos programas ou normas de execução, além disso, espera-se que o jurista apresente "como se pode" atingir os objetivos políticos em conformidade com o direito vigente.

Além da importância política vista acima, veremos a seguir que a participação dos Conselhos no processo orçamentário municipal é obrigatória segundo as disposições da Lei Orgânica Municipal de São Paulo.

\subsection{CONSELHOS E PROCESSO ORÇAMENTÁRIO MUNICIPAL SEGUNDO A LEI ORGÂNICA DO MUNICÍPIO DE SÃO PAULO}

O princípio da gestão orçamentária participativa ou da gestão democrática da cidade previsto na Lei de Responsabilidade Fiscal ${ }^{49}$ e no Estatuto da Cidade ${ }^{50}$ determina que o processo de elaboração e discussão do PPA, LDO e LOA conte com a participação popular, por meio de audiências públicas, tanto na fase de elaboração do projeto de lei pelo Poder Executivo, quanto na fase de discussão, emenda e aprovação pelo Poder Legislativo.

Em complemento, a Lei Orgânica Municipal de São Paulo (LOMSP) prevê que:

49 Lei Complementar Federal 101/00, inciso I do art. 48.

${ }^{50}$ Lei Federal 10.257/01, art. $2^{\circ}$, caput e incisos I, II e IV; art. $4^{\circ}$, inciso II, “f”; art. 44. 
Art. $8^{\circ}$ - O Poder Municipal criará, por lei, Conselhos compostos de representantes eleitos ou designados, a fim de assegurar a adequada participação de todos os cidadãos em suas decisões.

Art. $9^{\circ}$ - A lei disporá sobre: I - o modo de participação dos Conselhos, bem como das associações representativas, no processo de planejamento municipal e, em especial, na elaboração do Plano Diretor, do Plano Plurianual, das diretrizes orçamentárias e do orçamento anual;

Conforme dispõe a LOMSP, a participação dos Conselhos no processo de planejamento municipal é obrigatória e, em especial, na elaboração de peças orçamentárias retromencionadas, devendo a lei ordinária dispor sobre o "modo de participação", ou seja, a respeito dos procedimentos, etapas, prazos e competências legais de cada um dos órgãos envolvidos no processo orçamentário.

Os procedimentos de planejamento e orçamento de todos os Conselhos devem guardar sintonia com o calendário orçamentário do governo municipal ${ }^{51}$, pois este é momento em que a disputa política por recursos ocorre no seio da Administração Municipal. A preterição da participação dos Conselhos neste momento é nefasta para a obtenção de recursos orçamentários para os projetos e atividades selecionados como agenda. Sem recursos, estas políticas públicas não serão efetivadas, comprometendo, em última análise, a eficiência do Conselho em atingir seus objetivos e finalidades institucionais.

Outrossim, a capacidade de elaboração das políticas públicas pelos Conselhos é limitada pelo montante de receita estimado para determinada área social ou função de governo, por isso cabe aos conselheiros atuarem junto ao Poder Executivo, sensibilizando-o quanto à prioridade e viabilidade de determinado programa de ação, a fim de aumentarem a dotação orçamentária para determinada política pública ao invés de outra (s).

Faz-se necessário que o Poder Executivo remeta esta informação o mais breve possível ao Conselho ou com antecedência mínima de trinta dias antes do decurso do prazo para encaminhamento da proposta orçamentária do Conselho ao Executivo, analogicamente ao aplicado para o Poder Legislativo, Judiciário e ao Ministério Público nos termos da Lei de Responsabilidade Fiscal (art. 12, $3^{\circ}$ ).

Nesse sentido, o "Manual de Orçamento e Finanças Públicas para Conselheiros de Saúde”, elaborado pelo Conselho Nacional de Saúde na esfera do Ministério da Saúde, orienta que:

${ }^{51}$ Cf. 4.5 Instrumentos de planejamento urbano e orçamento municipal de São Paulo. 
Considerando que a receita orçamentária é a base de cálculo para definição do valor mínimo relativo aos gastos com ações e serviços de saúde nos níveis estadual e municipal de governo, os conselheiros de saúde devem solicitar o encaminhamento dos estudos realizados pelo Poder Executivo com a respectiva memória de cálculo da estimativa da receita (BRASIL, 2011, p. 39, grifo nosso).

Mesmo nos Conselhos dotados de competência meramente consultiva, nos termos do que dispõem os artigos $8^{\circ}$ e $9^{\circ}$ da LOMSP, as leis que os constituem devem prever o "modo de participação" dos Conselhos no processo de planejamento municipal, tanto sob o ponto de vista de sua organização interna quanto sob o viés da articulação administrativa com os demais órgãos envolvidos.

Porém, não basta a instituição meramente formal da participação, exige-se a reforma da própria burocracia estatal prevendo mecanismos de articulação administrativa, principalmente, quanto às competências de cada órgão a fim de evitar a sobreposição de competências pelos órgãos da Administração Pública e, consequentemente, provocar o enfraquecimento das competências institucionais dos Conselhos (SÁNCHEZ MORÓN, 1980).

\begin{abstract}
A articulação, em sentido restrito, é, pelo viés democrático, técnica relacional de núcleos de competências ou de agentes dos processos decisórios ou executivos da ação pública, que permite racionalidade de esforços e de utilização dos meios, ambiente de consensualidade e legitimação, consecução de resultados e compartilhamento de responsabilidades. Envolve a coordenação e a supervisão. Coordenar significa integrar, simplificar e unificar a ação do Estado, e supervisionar relaciona-se com o conceito de controle, garantindo que as políticas públicas sejam concebidas, implementadas e monitoradas de forma conjunta, voltadas para as necessidades de inclusão e desenvolvimento sociais (PIRES, 2010, p. 187).
\end{abstract}

Como se vê, a questão da articulação e coordenação mostra-se imprescindível para o sucesso da formulação e implementação da política pública. Daí a importância de que, primeiro, a regulamentação do processo orçamentário municipal inclua o Conselho em seu processo de formulação e implementação, efetivando as competências institucionais já previstas legalmente. Em seguida, é necessário que os procedimentos administrativos internos ao Conselho estejam em sintonia com o calendário orçamentário municipal, bem como articulados com os órgãos governamentais competentes.

Sem essa articulação do processo orçamentário municipal com os procedimentos internos do órgão ${ }^{52}$, o Conselho enfrentará dificuldades na elaboração de políticas públicas

\footnotetext{
${ }^{52}$ Cf. 3.4 Etapas do procedimento administrativo nos Conselhos.
} 
em cogestão com o poder público, correndo-se o risco de se tornar um órgão ineficiente, não por desídia de seus conselheiros, mas em razão da própria organização administrativa na qual está inserido (SÁNCHEZ MORÓN, 1980).

Conclusivamente, com base na LOMSP, é possível dizer que é obrigatória a participação dos Conselhos Municipais de Políticas Públicas de São Paulo no processo de planejamento municipal e com destaque para o processo de elaboração das peças orçamentárias (PPA, LDO e LOA).

Sendo assim, as respectivas leis instituidoras devem prever o "modo de participação" do Conselho de forma articulada e coordenada com os demais órgãos públicos encarregados da atividade de planejamento e orçamento municipal.

Mais à frente, analisaremos os instrumentos legais de planejamento da política urbana que constituem a finalidade institucional dos Conselhos, isto é, traduzir as demandas sociais e as respectivas propostas em programas de ação estatal, diretrizes, metas e recursos disponíveis para satisfazê-las. Antes, porém, faz-se necessário abordar os princípios jurídicos que regem essa atividade, logo abaixo.

\subsection{PRINCÍPIOS ORÇAMENTÁRIOS}

\subsubsection{Princípios da unidade, da universalidade e da especificação}

Segundo o princípio da unidade orçamentária, previsto no artigo $165, \S 5^{\circ}$, da Constituição Federal e no artigo $2^{\circ}$ da Lei ${ }^{\circ} 4.320 / 64$, a programação de receitas e despesas destinadas às políticas públicas devem ser agrupadas em uma única proposta orçamentária, vedando-se a adoção de orçamentos individuais para cada um dos órgãos ou poderes da Municipalidade, inclusive seus fundos, órgãos e entidades da administração direta e indireta.

O princípio da unidade do orçamento significa que a peça orçamentária deve seguir uma orientação política uniforme e harmônica, sobretudo para que seja possível integrá-la aos demais programas que compõem o orçamento (HENRIQUES, 2008).

O princípio da universalidade determina que todas as receitas e despesas do Estado devem estar previstas nas respectivas leis orçamentárias, não sendo permitida a realização de despesas ou a assunção de obrigações sem previsão legal $\left(\mathrm{CF} / 88\right.$, artigos $165, \S \S 5^{\circ}, 6^{\circ}$, 
$8^{\circ} ; 167$ e 169; $\operatorname{artigos} 3^{\circ}$ e $4^{\circ}$ da Lei $\left.n^{\circ} 4.302 / 64\right)$.

O princípio da especificação dispõe que a Lei Orçamentária Anual não consignará dotações globais, mas deverá detalhar as despesas a fim de permitir seu controle políticosocial (artigo $5^{\circ}$ da Lei $4.320 / 64^{53}$ ). Por outro lado, considerando que o detalhamento das despesas pode ser conduzido ao infinito, parâmetros mínimos encontram-se previstos na Portaria Ministerial 42/1999.

Como se vê, a proposta orçamentária setorial dos Conselhos Municipais de Políticas Públicas deve observar os princípios da unidade, da universalidade e da especificação, sem o que não será possível integrá-la ao projeto de lei orçamentária anual do respectivo Município.

\subsubsection{Princípio da anualidade}

O princípio da anualidade limita a previsão do orçamento público ao ano civil, ou seja, de $1^{\circ}$ de janeiro a 31 de dezembro. Isso quer dizer que a Lei Orçamentária Anual e a Lei de Diretrizes Orçamentárias devem prever despesas e receitas circunscritas ao mesmo exercício financeiro conforme dispõe o artigo 34 da Lei 4.320/64. Já as despesas ou investimentos que ultrapassem o exercício financeiro somente poderão ser iniciados se previstos no Plano Plurianual, sob pena de responsabilidade nos termos do artigo $167, \S^{\circ}$ da Constituição Federal.

O mesmo se aplica aos Conselhos de Políticas Públicas, cujas propostas orçamentárias devem observar a periodicidade do processo orçamentário global da Municipalidade.

\subsubsection{Princípio da transparência e da gestão democrática das cidades}

Os princípios da transparência e da gestão orçamentária participativa visam garantir

\footnotetext{
${ }^{53}$ Lei Federal 4.320/64, art. 5 A Lei de Orçamento não consignará dotações globais destinadas a atender indiferentemente as despesas de pessoal, material, serviços de terceiros, transferências ou quaisquer outras, ressalvado o disposto no art. 20 e seu parágrafo único.
} 
a efetivação do Estado Democrático de Direito, que exige a participação popular na elaboração das leis orçamentárias.

Para esse fim, os princípios da publicidade e da transparência orçamentária efetivam-se por meio do exercício do direito à informação ${ }^{54}$; certidão ${ }^{55}$, habeas data $^{56}$ e na divulgação bimestral da execução orçamentária ${ }^{57}$ etc.

Segundo o princípio da gestão orçamentária participativa, o processo de elaboração e discussão dos planos, leis e diretrizes orçamentárias e orçamentos deve contar com a participação popular pela realização de audiências públicas (LRF - Lei Complementar 101/00, art. 48, inciso I).

No caso dos planos, programas e projetos de desenvolvimento urbano, falamos em gestão democrática da cidade, a partir da qual o processo orçamentário deverá ser acompanhado de debates em colegiados, consultas e audiências públicas, além da possibilidade de apresentação de projeto orçamentário de iniciativa popular conforme previsto no Estatuto da Cidade (arts. $2^{\circ}$, inciso II, e 43).

Assim, as referidas peças orçamentárias, as prestações de contas e o respectivo parecer prévio, o relatório resumido da execução orçamentária e o relatório de gestão fiscal e as versões simplificadas desses documentos deverão ser amplamente divulgadas, inclusive por meio eletrônico de acesso público (LRF, art. 48, caput).

Mais recentemente, a Lei de Acesso à Informação (LAI - Lei n. 12,527/2011) consagrou o meio eletrônico como o mais adequado para a efetivação do direito fundamental à informação. Desde então, a divulgação ativa de informações de interesse coletivo ou geral por meio de portais públicos na internet é obrigatória.

Além disso, na forma do regulamento, os portais devem: 1) possuir ferramenta de pesquisa; 2) disponibilizar o acesso de forma objetiva, transparente, clara e em linguagem de fácil compreensão; 3) e, em destaque, apresentar relatórios em formatos abertos e não proprietários, para facilitar a análise das informações, bem como permitir acesso automatizado por sistemas externos.

Ao dispor desse modo, a legislação brasileira alinha-se às orientações modernas de difusão da informação, permitindo que cidadãos e instituições privadas não governamentais processem e/ou utilizem os dados disponibilizados de modo a torná-los mais claros,

\footnotetext{
${ }^{54} \mathrm{CF}$, art. $5^{\circ}$, inciso XXXIII.

${ }^{55} \mathrm{CF}$, art. 5', XXXIV, alínea "b".

${ }^{56} \mathrm{CF}$, art. $5^{\circ}$, LXXII.

${ }^{57} \mathrm{CF}, 165, \S 3^{\circ}$.
} 
analíticos, úteis, inteligíveis e controláveis pelos cidadãos.

Em sintonia com a superveniente lei de acesso à informação, a LRF já dispunha que as informações pormenorizadas sobre a execução orçamentária e financeira devem ser divulgadas, em tempo real, em meios eletrônicos de acesso público, com destaque para as despesas e receitas (art. 48, parágrafo único, incisos II e III; e art. 48-A).

Como se vê, a transparência orçamentária está intimamente relacionada aos instrumentos eletrônicos de democracia participativa; sobretudo nas questões envolvendo planos, programas e projetos de desenvolvimento urbano.

\subsection{INSTRUMENTOS DE PLANEJAMENTO URBANO E ORÇAMENTO MUNICIPAL DE SÃO PAULO 58}

\subsubsection{Plano diretor estratégico}

O Plano Diretor Estratégico (PDE), regulamentado pelo Estatuto da Cidade - Lei Federal 10.257/01 - é um instrumento basilar para política de desenvolvimento e expansão urbana, previsto nos artigos $182, \S 1^{\circ}$ da Constituição Federal, tendo por finalidade regulamentar o cumprimento da função social da cidade e da propriedade em prol do bem coletivo, segurança e bem-estar dos cidadãos e a proteção do meio ambiente.

Para tanto, define os casos em que o exercício irregular da propriedade acarretará a instituição de Imposto de Propriedade Territorial Urbana (IPTU) com alíquota progressiva no tempo, bem como a obrigação de parcelamento, utilização ou edificação compulsórios ou até a desapropriação do solo não edificado, subutilizado ou não utilizado, com pagamento em títulos públicos.

\footnotetext{
${ }^{58}$ Desde já ressaltamos ao leitor que o rol de instrumentos legais de planejamento da política urbana não se esgota no rol apresentado no presente tópico. Aliás, o próprio Estatuto da Cidade (Lei Federal 10.257/01) elenca dezenas de outros e ainda assim de forma não exaustiva, conforme se depreende da expressão "entre outros instrumentos" do art. $4^{\circ}$, caput. Deste modo, para os fins do presente trabalho, procuramos nos concentrar nos instrumentos de planejamento que têm reflexo direto na atividade dos Conselhos Municipais de Políticas Públicas. Para fins didáticos, enquadramos o Plano Diretor Estratégico, os Planos Setoriais e o Programa de Metas na etapa de definição da agenda política, uma vez que suas prioridades, diretrizes e metas constituem o substrato sobre o qual as políticas públicas devem ser elaboradas na etapa seguinte. Trata-se apenas de uma generalização didática, pois a elaboração da política pública concreta (projetos e atividades) acarretará igualmente numa seleção de prioridade entre situações problemáticas e que também poderiam ser consideradas na etapa da agenda (v.g. construir habitações de interesse popular na região "y" ou "z").
} 
Sua edição é ato-condição para a utilização de diversos instrumentos de política urbana previstos no Estatuto da Cidade, tais como: a delimitação das áreas urbanas onde poderão ser aplicadas as medidas coercitivas citadas acima (art. $5^{\circ}$ a $6^{\circ}$ ); o direito de perempção na alienação de imóveis em determinadas áreas (art. 25); a outorga onerosa do direito de construir (art. 28 a 31); operações consorciadas (art. 32 a 34-A); da transferência do direito de construir (art. 35) (CÂMARA, 2002; CARVALHO FILHO, 2010).

Deve ser revisado a cada dez anos por meio de projeto de lei de iniciativa do Poder Executivo municipal, seguindo o disposto no artigo 40, $\S 3^{\circ}$ do Estatuto da Cidade.

O Plano Diretor encontra-se no topo das diretrizes, metas, programas e projetos de desenvolvimento urbano e de expansão da cidade. Tendo por escopo um período de longa data, incide na formulação dos demais instrumentos de planejamento (Plano Plurianual, Lei de Diretrizes Orçamentárias, Lei Orçamentária Anual e Plano de Metas) tal como dispõe o artigo 39, $\S 9^{\circ}$ do Estatuto da Cidade c.c. artigo 69-A da Lei Orgânica Municipal de São Paulo (LOMSP).

O atual Plano Diretor do Município de São Paulo encontra-se previsto na Lei Municipal 16.050, de 31 de julho de 2014, o qual compõe e orienta a política urbana municipal, constituída pela Lei de Parcelamento, Uso e Ocupação do Solo, Planos Regionais das Subprefeituras, Planos de Bairros, planos setoriais de políticas urbano-ambientais e demais normas correlatas.

O processo de elaboração do PDE deve contar com ampla publicidade e participação popular por meio de audiências públicas e do acesso de qualquer interessado aos documentos e informações nele produzidos, tanto na fase administrativa de elaboração no Poder Executivo quando na fase de discussão e aprovação no Poder Legislativo conforme preveem os artigos $40, \S 4^{\circ}$, I, do Estatuto da Cidade e artigo 41, I, da LOMSP.

No caso do Município de São Paulo, o Decreto Municipal 56.268 59 , de 22 de julho de 2015 conferiu ao Conselho Municipal de Política Urbana (CMPU), instituído pela Lei Municipal 16.050, de 31 de julho de $2014^{60}$, as seguintes atribuições: a) debater e apresentar sugestões às propostas de alteração do Plano Diretor Estratégico; b) debater e elaborar

\footnotetext{
${ }^{59}$ Decreto Municipal 56.268, de 22 de julho de 2015. Diário Oficial da Cidade de São Paulo. Poder Executivo. 23 jul. 15 , p. 03-05.

${ }^{60}$ Cabe mencionar que o CMPU é composto de representantes dos seguintes Conselhos de Políticas Públicas: a) 1 (um) representante escolhido dentre os membros do Conselho Municipal do Meio Ambiente e Desenvolvimento Sustentável - CADES; b) 1 (um) representante eleito dentre os membros do Conselho Municipal de Planejamento e Orçamento Participativos - CPOP; c) 1 (um) representante eleito dentre os membros do Conselho Municipal de Trânsito e Transporte - CMTT; e) 1 (um) representante eleito dentre os membros do Conselho Municipal de Habitação - CMH.
} 
propostas de projetos de lei de interesse urbanístico e regulamentações decorrentes do Plano Diretor Estratégico; c) encaminhar ao Executivo ao final de cada gestão, para subsidiar a elaboração do Programa de Metas do próximo Governo, memorial sugerindo prioridades no tocante à implantação do Plano Diretor Estratégico; d) encaminhar propostas aos órgãos municipais e conselhos gestores dos fundos públicos municipais com o objetivo de estimular a implementação das ações prioritárias contidas no Plano Diretor Estratégico, por meio da integração territorial dos investimentos setoriais.

As Subprefeituras, em conjunto com o Conselho Participativo Municipal, instituído pela Lei Municipal 15.764/13 e regulamentado pelo Decreto Municipal 54.156/13 ${ }^{61}$, devem realizar a cada ano uma reunião de avaliação e acompanhamento da implantação do Plano Diretor, do respectivo Plano Regional e dos demais instrumentos urbanísticos. Deverá então apresentar um relatório de avaliação, publicado no Diário Oficial da Cidade e no portal eletrônico da Prefeitura em até 15 (quinze) dias úteis, e subsidiará as deliberações do Conselho Municipal de Política Urbana acerca das ações prioritárias para implantação do Plano Diretor.

Como se vê, o atual Plano Diretor Estratégico de São Paulo prevê um Sistema Municipal de Planejamento Urbano, formado para rever anualmente as diretrizes, metas, programas e projetos de desenvolvimento urbano e de expansão da cidade, contando com intensa participação popular, o qual pode ser esquematizado da seguinte forma:

\footnotetext{
${ }^{61}$ Decreto Municipal 54.156/13, “Art. $2^{\circ}$ Cada Subprefeitura deverá instalar o respectivo Conselho Participativo Municipal para atuação nos limites de seu território administrativo. $\S 1^{\circ} \mathrm{O}$ Conselho Participativo Municipal tem caráter eminentemente público e é organismo autônomo da sociedade civil, reconhecido pelo Poder Público Municipal como instância de representação da população de cada região da Cidade para exercer o direito dos cidadãos ao controle social, por meio da fiscalização de ações e gastos públicos, bem como da apresentação de demandas, necessidades e prioridades na área de sua abrangência. $\S 2^{\circ} \mathrm{O}$ Conselho Participativo Municipal buscará articular-se com os demais conselhos municipais, conselhos gestores e fóruns criados pela legislação vigente, não os substituindo sob nenhuma hipótese. $3^{\circ} \mathrm{O}$ Conselho Participativo Municipal tem caráter transitório e subsistirá até que o Conselho de Representantes de que tratam os artigos 54 e 55 da Lei Orgânica do Município possa validamente existir e estar em funcionamento". SÃO PAULO (cidade). Diário Oficial da Cidade de São Paulo. Poder Executivo, 02 ago. 13, p. 01. $2013 \mathrm{f}$.
} 


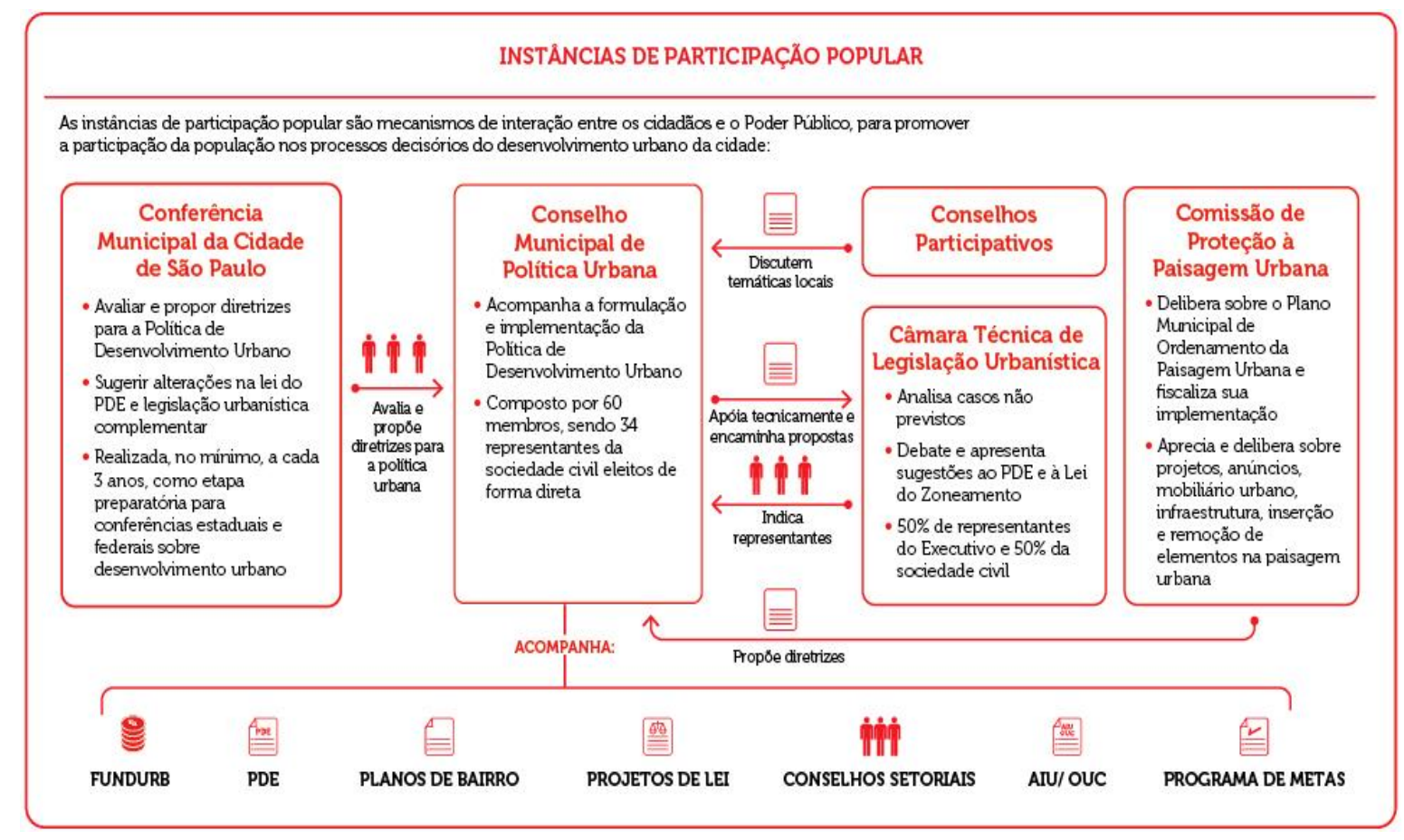

Esquema 1 - Instâncias de participação popular.

Fonte: Plano Diretor Estratégico Ilustrado (São Paulo, 2014).

Tal como ressaltado na LOMSP, art. $8^{\circ}$ e $9^{\circ}$, a legislação municipal de São Paulo deverá dispor sobre o modo de participação dos Conselhos no processo de formulação e revisão do PDE em coordenação com o Poder Executivo e o Poder Legislativo, sobretudo, no que diz respeito aos prazos e competências legais de cada órgão.

Já no âmbito interno de cada Conselho, a lei instituidora e o respectivo Regimento Interno devem prever procedimentos específicos para a elaboração ou alteração do PDE, observados os aspectos materiais e formais do instituto, bem como o cumprimento dos prazos e condições previstos na legislação e decretos municipais.

\subsubsection{Programa de metas}

O Programa de Metas é uma exigência do art. 65-A da Lei Orgânica de São Paulo, instituída pela Emenda n $30 / 2008$ a partir de um projeto legislativo protagonizado por diversas organizações da sociedade civil, dentre as quais se destaca a Rede Nossa São Paulo, 
movimento integrado por mais de 700 (setecentas) organizações da sociedade civil ${ }^{62}$.

A partir das diretrizes da campanha eleitoral, o candidato eleito à Prefeitura deve apresentar o chamado Programa de Metas, cujo conteúdo, deve especificar as ações estratégicas, indicativos e metas quantitativas a serem adotadas por cada um dos setores da Administração Pública Municipal, Subprefeituras e Distritos durante o mandato. Além disso, os objetivos, as diretrizes, as ações estratégicas e as demais normas previstas no PDE deverão ser incorporadas ao Programa de Metas.

Embora a lei não obrigue a submissão do Programa de Metas à participação popular, importante ressaltar o processo participativo desenvolvido para a revisão do Plano de Metas 2013-2016 no Município de São Paulo. Após sua apresentação no prazo de noventa dias exigido pela legislação, em abril de 2013 o plano foi apreciado em 35 (trinta e cinco) audiências públicas realizadas nas subprefeituras da cidade. Após essa rodada e a partir das contribuições colhidas nas audiências públicas, a Prefeitura fez alterações no Programa de Metas e submeteu-o, em agosto de 2013, a mais 32 (trinta e duas) audiências devolutivas nas subprefeituras. Somente então, com as novas contribuições devolutivas, a Prefeitura consolidou, em outubro de 2013, a versão final do Programa de Metas, que contou com a incorporação de outras 28 metas não previstas no Programa original, sendo inclusive integrado ao Plano Plurianual apresentado à Câmara Municipal em 30 de setembro daquele ano. Estas e outras informações constam do portal eletrônico www.planejasampa.prefeitura.sp.gov.br/ (SÃO PAULO, 2013).

Por fim, importante destacar que a atividade de planejamento dos Conselhos deverá observar o disposto no Programa de Metas para a elaboração dos projetos das diversas peças orçamentárias relativamente a suas áreas de competência, tais como o Plano plurianual, a Lei de Diretrizes Orçamentárias e a Lei Orçamentária Anual.

\subsubsection{Leis orçamentárias}

O Plano plurianual (PPA) tem como precedentes o Quadro de Recursos e de Aplicação de Capital (QRAC) previsto na Lei 4.320/64, artigos 23 a 26 e, posteriormente, o Orçamento Plurianual de Investimentos (OPI) instituído pela Emenda Constitucional $\mathrm{n}^{\circ}$,

62 Informações colhidas no site da "Rede Nossa São Paulo". Disponível em: http://www.nossasaopaulo.org.br/portal/quem. Acesso em 04/07/2015. 
de 1969, art. 60, parágrafo único. O QRAC abrangia as receitas e despesas de capital ${ }^{63}$, era aprovado por decreto do Poder Executivo, compreendia o período de três anos e era anualmente atualizado, acrescentando-se mais um ano. Foi substituído pelo OPI, que manteve o mesmo modelo anterior, com exceção de que passou a ser aprovado por lei. Embora tivessem previsão plurianual das despesas de capital, não previam as despesas permanentes e decorrentes (de sua implementação) e, além disso, não tinha caráter de autorização plurianual da despesa, transferindo esse papel à lei orçamentária anual. Por isso, não realizava sua finalidade de planejamento de médio prazo, tornando-se peça meramente burocrática (GIACOMONI, 2012).

A fim de retomar o processo de planejamento das políticas públicas, a Constituição Federal de $1988\left(\right.$ art. $\left.165, \S 1^{\circ}\right)$ instituiu o PPA propriamente dito, que tem por objetivo fixar de forma regionalizada, as diretrizes, objetivos e metas da administração pública para as despesas de capital e, agora sim, outras delas decorrentes e para os programas de duração continuada, os quais correspondem às despesas que ultrapassam um exercício financeiro.

Procurando superar as deficiências do OPI, a Constituição atentou para o fato de que os programas de duração continuada são usualmente viabilizados por investimentos, os quais, mesmo após sua conclusão, continuarão demandando recursos de operação e manutenção (reformas, salários, despesas correntes etc.). Daí a importância de se prever as despesas de duração continuada no Plano plurianual (GIACOMONI, 2012).

O PPA deve ainda incorporar as diretrizes, objetivos e metas de longo prazo previstas no Plano Diretor Estratégico, bem como integrar as diretrizes, objetivos e metas de médio prazo constantes no Programa de Metas. Por sua vez, o PPA deverá ser observado na elaboração da lei de diretrizes orçamentárias e da lei orçamentária anual.

No Município de São Paulo, o Poder Executivo deverá enviar mensagem ao Poder Legislativo contendo o projeto de lei do PPA até 30 de setembro do primeiro ano de mandato, em seguida ser votado e remetido para sanção do Executivo até 31 de dezembro ${ }^{64}$. Sua vigência será de quatro anos a se iniciar no segundo ano do mandato governamental, visando

\footnotetext{
${ }^{63}$ De acordo com os comentários de Kiyoshi Harada sobre o artigo 12 da Lei Federal 4.320/64: “As despesas de capital abrangem: os investimentos, que correspondem, entre outros, às dotações para planejamento e execução de obras (§4); as inversões financeiras, que são conformes às dotações para aquisição de imóveis, constituição de aumento de capital das entidades ou empresas que visem a objetivos comerciais ou financeiros etc. $\left(\$ 5^{\circ}\right)$, e transferência de capital, que são correlatas às dotações para investimentos ou inversões financeiras que outras pessoas de direito público ou privado devam realizar, independentemente de contraprestação direta em bens ou serviços, bem como as dotações para amortização da dívida pública (§6º)" (HARADA, 2012, p. 23).

64 A Lei Orgânica de São Paulo - art. 138, §6º inciso II e $\$ 10$ - dispõe que o Prefeito enviará o projeto do plano plurianual à Câmara Municipal até 30 de setembro e será votado e remetido à sanção até 31 de dezembro.
} 
promover a continuidade das políticas públicas de uma gestão para outra.

Para a elaboração da proposta do PPA 2013-2017, a Prefeitura Municipal de São Paulo editou a Portaria Intersecretarial 4/13 - SEMPLA/SF ${ }^{65}$, segundo a qual cada programa de trabalho ${ }^{66}$ deverá ser identificado por: a) Órgão responsável; b) Descrição do Programa e prazo de vigência; c) Valor global e respectivas fontes de financiamento; d) Identificação da região a ser beneficiada; e) Estabelecimento de indicadores que quantifiquem ou qualifiquem a situação que deu origem ao Programa; f) Ações necessárias à consecução do objetivo com o respectivo valor estimado anualmente e, no caso das ações do Programa de Metas, a especificação dos respectivos subprojetos.

Já a Lei de Diretrizes Orçamentárias (LDO) compreenderá as metas e prioridades da administração pública, incluindo as despesas de capital para o exercício financeiro subsequente seguindo a programação plurianual do PPA; orientará a elaboração da lei orçamentária anual, disporá sobre as alterações na legislação tributária e estabelecerá a política de aplicação das agências financeiras oficiais de fomento $\left(\mathrm{CF}\right.$, art. 165, §2 $2^{\circ}$. Além disso, na prática, “a LDO progressivamente vem sendo utilizada como veículo de instruções e regras a serem cumpridas na execução do orçamento" (GIACOMONI, 2012, p. 229).

Sua periodicidade é anual. No Município de São Paulo, o Poder Executivo deverá enviar mensagem ao Poder Legislativo contendo o projeto de lei da LDO até 15 de abril e será devolvido para sanção até o encerramento do primeiro período da sessão legislativa 30 de julho ${ }^{67}$, podendo este prazo variar entre os estados e municípios (art. 35, §2 , inciso II do ADCT).

Conforme observa Kiyoshi Harada, na LDO devem constar as despesas de capital e orientações formais para elaboração da lei orçamentária, bem como a previsão de eventuais alterações que impliquem aumento ou diminuição da arrecadação tributária para o exercício seguinte, as quais refletirão na estimativa de receitas do orçamento anual. Destaca-se ainda o financiamento concedido pelas agências financeiras oficiais de fomento ${ }^{68}$ para os

\footnotetext{
${ }^{65}$ Publicada no Diário Oficial da Cidade de São Paulo em 29/06/13, p. 122.

66 “Os programas de trabalho do governo são 'os instrumentos de organização da ação governamental visando à concretização dos objetivos pretendidos” (Portaria MOG 42/1999, art. 2ª, $a$; e Lei 11.439/2006 - LDO União 2007 , art. $5^{\circ}$, I), e constituem o principal instrumento de veiculação do orçamento por programas, fundado na classificação das despesas por função e programa de governo" (CONTI, 2008, p. 97).

${ }^{67}$ A Lei Orgânica de São Paulo - art. 138, $\S 6^{\circ}$, inciso I e $\$ 9^{\circ}$ - dispõe que o Prefeito enviará o projeto de lei de diretrizes orçamentárias à Câmara Municipal até 15 de abril e será votado e remetido à sanção até 30 de junho. ${ }^{68}$ A Caixa Econômica Federal nos programas de redução do déficit habitacional e saneamento básico; o Banco do Brasil nos programas voltados para a atividade agrícola; o Banco Nacional de Desenvolvimento Econômico (BNDS) nos programas de duração continuada previstos no PPA, ou no financiamento das micro, pequenas e médias empresas e; os Bancos do Nordeste e da Amazônia voltados para o desenvolvimento regional (HARADA, 2012, p. 83).
} 
programas de duração continuada previstos no PPA (HARADA, 2012).

Deste modo, a LDO serve, em suma, como lei intermediária entre os objetivos e metas plurianuais previstos no PPA e as despesas a serem empenhadas no exercício seguinte, bem como para guiar formalmente a elaboração da lei orçamentária anual.

Por fim, a Lei Orçamentária Anual (LOA) tem caráter específico e concreto, devendo relacionar receitas e despesas em torno de programas, objetivos, público-alvo, ação, meta, órgão responsável e valor da dotação (CONTI, 2008).

A LOA compreende a previsão da receita e à fixação da despesa do orçamento fiscal referente aos Poderes do Município, seus fundos, órgãos e entidades da administração direta e indireta, inclusive fundações instituídas e mantidas pelo Poder Público (CF, art. 165, §5º $)$.

Sua periodicidade é anual e seu processo orçamentário se inicia logo após a votação do projeto da LDO pela Câmara Municipal de São Paulo em 30 de junho. Então, o Poder Executivo terá o prazo de 30 de setembro para enviar mensagem à Câmara Municipal contendo o projeto da LOA, acompanhada das informações descritas no inciso I do art. 22 da Lei 4.320/194, acrescidas das tabelas a que se refere o inciso III do mesmo dispositivo legal. A votação pelo Legislativo deverá ocorrer até o fim da sessão legislativa, em 31 de dezembro, podendo este prazo variar entre os estados e municípios ${ }^{69}$ (art. $35, \S 2^{\circ}$, inciso III do ADCT).

Será considerada "compatível com o plano plurianual e a lei de diretrizes orçamentárias, a despesa que se conforme com as diretrizes, objetivos, prioridades e metas previstos nesses instrumentos e não infrinja qualquer de suas disposições” (LRF, art. 16, § $1^{\circ}$, II).

Caso algum programa não tenha sido incluído no orçamento e se mostre necessário, pode-se proceder à abertura de créditos especiais por meio de projeto de lei específica para essa finalidade alterando a LDO, acompanhada da abertura de créditos adicionais suplementares ou crédito extraordinário, a saber: superávit financeiro; excesso de arrecadação; anulações de dotações; operações de empréstimo e financiamento não previstos como receitas na LOA (art. 43 da Lei $n^{\circ} 4.320 / 64$ ).

\footnotetext{
${ }^{69}$ A Lei Orgânica de São Paulo - art. 138, §6 $6^{\circ}$, inciso II e $\$ 10$ - dispõe que o Prefeito enviará o projeto da lei
} orçamentária à Câmara Municipal até 30 de setembro e será votado e remetido à sanção até 31 de dezembro. 


\title{
4.5.4 Normas procedimentais
}

A Constituição Federal de 1998 (art. 165, §9º determinou que as normas gerais de gestão financeira fossem reguladas por lei complementar, a qual ainda não foi promulgada. Enquanto isso, as normas gerais para elaboração e controle das peças orçamentárias no âmbito dos municípios são disciplinadas pelo sistema ${ }^{70}$ da Lei $4.320 / 64^{71}$, Lei Complementar 101/01 (LRF - Lei de Responsabilidade Fiscal), Lei 10.257/01 (Estatuto da Cidade) e pelo $\S 2^{\circ}$ do art. 35 do Ato das Disposições Constitucionais Transitórias.

Limitando-nos aos objetivos do presente trabalho, analisaremos somente a fase de elaboração da proposta orçamentária na esfera do Poder Executivo, também chamada de fase administrativa.

\begin{abstract}
A primeira, que denomino de fase administrativa, compreende o período que vai do início das previsões e cálculos nas várias unidades orçamentárias e demais órgãos que integram o processo de elaboração da lei orçamentária, até o momento em que se finaliza a proposta de lei orçamentária, encaminhando-a ao Poder Legislativo para deliberação e aprovação (fase legislativa) (CONTI, 2008, p. 101).
\end{abstract}

De acordo com as disposições da Lei 4.320/64, artigos 23 a 33, José Maurício Conti descreve que a elaboração das propostas orçamentárias envolve três naturezas de agentes: órgão central, os órgãos setoriais e as unidades orçamentárias, cada um responsável por uma etapa do processo orçamentário (CONTI, 2008).

Às categorias supracitadas, deve ser acrescida ainda a participação popular em audiências públicas como agente do processo de elaboração das propostas orçamentárias, conforme previsto na Lei de Responsabilidade Fiscal ${ }^{72}$ e no Estatuto da Cidade $^{73}$.

Embora a Lei 4.320/64 trate especificamente do procedimento de elaboração da LOA, as orientações gerais citadas abaixo servem de modelo para a elaboração do PPA e da LDO, observando-se as especificidades formais e materiais descritas no tópico precedente ${ }^{74}$.

No Município de São Paulo, as funções de órgão central ${ }^{75}$ são exercidas pela

\footnotetext{
${ }^{70} \mathrm{Na}$ esfera federal, acrescenta-se o regramento do Decreto-Lei 200/67.

${ }^{71}$ Com relação à Lei Federal 4.320/64, esta foi parcialmente derrogada pela Constituição Federal de 1988, principalmente quanto às supervenientes disposições relativas ao PDE, PPA e LDO não existentes na época da edição da lei na parte em que conflitam com o regramento constitucional (HARADA, 2012, p. 87).

72 Lei Complementar Federal 101/00, inciso I do art. 48.

${ }^{73}$ Lei Federal 10.257/01, art. $2^{\circ}$, caput e incisos I, II e IV; art. 4º inciso II, “f”; art. 44.

${ }^{74}$ Cf. tópico 4.5.4 Leis orçamentárias.

${ }^{75} \mathrm{Na}$ União, o órgão central coincide com o Ministério do Planejamento, Orçamento e Gestão (MPOG), que
} 
Secretaria Municipal de Finanças e Desenvolvimento Econômico (SF), órgão responsável pelo assessoramento, planejamento, coordenação, supervisão, orientação técnica, controle, execução e avaliação, em nível central, dos Sistemas de Planejamento e Orçamento (PPA, LDO e LOA) municipal ${ }^{76}$.

Por sua vez, os órgãos setoriais, a exemplo das demais Secretarias de governo, correspondem aos órgãos político-administrativos responsáveis pela coordenação e supervisão de entes da administração direta ou indireta, responsáveis pela implementação das políticas públicas.

As unidades orçamentárias correspondem ao menor nível de classificação institucional para fins de dotação orçamentária, coincidindo ou não com as chamadas unidades administrativas, estas encarregadas de executar os programas de trabalho (políticas públicas) (CONTI, 2008; GIACOMONI, 2012).

Numa etapa preliminar, cabe ao órgão central planejar o processo de elaboração da proposta orçamentária, definindo etapas, agentes responsáveis, cronograma, estabelecendo as prioridades e metas. Deve ainda proceder ao cálculo da estimativa de receita considerando o período de cada uma das peças orçamentárias - quatro anos no caso do PPA e um ano no caso da LDO e LOA, fixando, posteriormente, a estimativa de recursos disponíveis (parâmetros orçamentários) disponível para cada um dos órgãos setoriais, para que, com base neles, possam consolidar a proposta orçamentária setorial (CONTI, 2008; GIACOMONI, 2012).

Os parâmetros orçamentários (recursos disponíveis) são deliberados pela Junta Orçamentária de Finanças - JOF ${ }^{77}$, instituída pelo Decreto Municipal 53.687/13 ${ }^{78}$, alterada pelo Decreto Municipal 55.966/15, composta pelos titulares da Secretaria de Finanças e Desenvolvimento Econômico, que a preside, Secretaria Municipal de Gestão, Secretaria do Governo Municipal e Secretaria Municipal dos Negócios Jurídicos.

Na etapa intermediária, a partir do levantamento anual dos problemas prioritários e dos programas de trabalho necessários para sua superação, os órgãos setoriais fixam os

\footnotetext{
tem a atribuição de coordenar, consolidar e supervisionar a elaboração das pelas orçamentárias pela Secretaria de Orçamento Federal (SOF). Como órgãos setoriais, os demais Ministérios intermediam o processo orçamentário entre o SOF e as unidades orçamentárias a eles submetidas, estas responsáveis, em última análise, pela elaboração do programa de trabalho e pela execução orçamentária (GIACOMONI, 2012, p. 248).

${ }^{76}$ Decreto Municipal 54.498/13, alterado pelo Decreto Municipal 55.966/15, de 27 de fevereiro de 2015, dispõe sobre alteração na estrutura administrativa do município. Diário Oficial da Cidade de São Paulo. Poder Executivo. 28 fev. 15, p. 01.

${ }^{77}$ Cf. Portaria Intersecretarial 115/15 - SF.

78 Decreto Municipal 53.687/13, de 02 de janeiro de 2013, dispõe sobre a criação da Junta OrçamentárioFinanceira - JOF. Diário Oficial da Cidade de São Paulo. Poder Executivo, 03 jan. 13, p. 01.
} 
parâmetros orçamentários e as diretrizes setoriais, encaminhando-os às unidades orçamentárias. Com base neles, estas passam a alocar os recursos disponíveis (dotações orçamentárias) em projetos, atividades ou operações especiais ${ }^{79}$ voltadas à implementação daqueles programas, consolidando-os em suas propostas parciais e então as remetendo ao órgão setorial. Como último passo, cabe ao órgão setorial a articulação e coordenação dos interesses das diversas unidades orçamentárias, verificando o cumprimento dos parâmetros orçamentários e diretrizes setoriais para, ao final, consolidar a proposta orçamentária do órgão setorial, remetendo-a ao órgão central (CONTI, 2008; GIACOMONI, 2012).

Na etapa final, compete ao órgão central ajustar as diversas propostas setoriais aos parâmetros orçamentários e às diretrizes gerais, consolidando a proposta orçamentária, a qual é encaminhada ao Prefeito Municipal acompanhada da exposição de motivos da SF. Havendo concordância, o Prefeito remete o projeto de lei para a Câmara Municipal por meio de mensagem, observados os prazos, aspectos formais e materiais de cada uma das peças orçamentárias (CONTI, 2008; GIACOMONI, 2012).

Para elaboração da proposta de Lei Orçamentária de 2016 e acompanhamento de sua execução, a Prefeitura Municipal de São Paulo editou a Portaria Intersecretarial 115/15 - SF (SÃO PAULO, 2015a), determinando a constituição, no âmbito de cada Secretaria e Subprefeitura, da Controladoria Geral do Município, da Câmara Municipal e do Tribunal de Contas do Município, um Grupo de Planejamento - GP, encarregado de:

I - Coordenar a elaboração da proposta de orçamento para o exercício de 2016, observados os parâmetros definidos pela Junta OrçamentárioFinanceira - JOF; II - Participar do processo de capacitação para a elaboração da proposta orçamentária para 2016; III - Traduzir as prioridades das áreas de atuação para o exercício de 2016 em Programas, Projetos, Atividades, Operações Especiais e Detalhamento das Ações (DA), especificando-as para as unidades orçamentárias, órgãos, fundos, autarquias e fundações, garantindo a integração das ações de sua área de competência; IV - Promover, em relação a sua área de competência, a compatibilidade e a coerência da programação proposta com o estabelecido na Lei de Diretrizes Orçamentárias para 2016, com o Plano Plurianual 2014 - 2017, com o Programa de Metas 2013-2016 e com os resultados do Ciclo Participativo de Planejamento e Orçamento; V - Garantir, sempre

\footnotetext{
79 “Projeto é o instrumento de programação destinado a alcançar o objetivo de um programa, que compreende um conjunto de operações, em um determinado período, que resultam em um produto voltado à expansão ou ao aperfeiçoamento da ação de governo (Portaria 43, art. $2^{\circ}, b$; Lei 10.934/2004, art. 4º III). Já a atividade corresponde a um instrumento de programação que visa alcançar um objetivo de um programa, envolvendo um conjunto de operações contínuas e permanentes, das quais resulta um produto necessário à manutenção do Governo (Portaria 42, art. $2^{\circ}, c$; Lei 10.934/2004, art. $4^{\circ}$, II). Operações especiais é uma categoria que engloba as despesas que não contribuem para a manutenção das ações do governo, das quais não resulta um produto, e não geram contraprestação sob a forma de bem ou serviço (Portaria 42, art. $2^{\circ}$, $d$; Lei 10.937/2004, art. $4^{\circ}$, IV) " (CONTI, 2008, p. 97).
} 
que couber, a compatibilidade entre as previsões de receita e de despesa; VI - Cadastrar as informações relativas à Proposta Orçamentária 2016 no Módulo de Planejamento Orçamentário do Sistema de Orçamento e Finanças - SOF, a saber: inserção de valores das dotações e detalhamento da ação, Plano de Ação, Legislação e Atribuições do Órgão (campos obrigatórios), cujo não preenchimento inviabilizará a entrega eletrônica; VII - Proceder à entrega eletrônica da proposta de orçamento dos órgãos orçamentários sob sua responsabilidade (...)

Como se pode observar, os Grupos de Planejamentos (CP) foram instituídos em órgãos responsáveis (órgãos setoriais) por consolidar a proposta orçamentária setorial a partir das propostas parciais das unidades administrativas, encaminhando-a eletronicamente ${ }^{80}$ à SF (órgão central) entre o prazo inicial de 26 de junho de 2015 e o prazo final de 14 de agosto de 2015.

Deve-se anotar também que, paralelamente ao processo de elaboração interna da proposta, a Prefeitura convocou Audiências Públicas nas 32 subprefeituras do Município nos dias 18 e 28 de julho de 2015, chamada de Ciclo Participativo de Planejamento e Orçamento $^{81}$, cujos resultados deverão ser considerados pelos respectivos GP na apresentação de suas propostas orçamentárias setoriais conforme previsto na Portaria retromencionada.

As disposições da Portaria Intersecretarial 115/15 - SF aplicam-se: I - Aos Órgãos Orçamentários da Administração Direta do Poder Executivo, incluindo Secretarias, Subprefeituras e Fundos Municipais. Além disso, "o Grupo de Planejamento da Secretaria a que são vinculadas Autarquias, Fundações e Empresas Públicas deverá incluir membro representante de cada um desses entes", conforme dispõem, respectivamente, os artigos $1^{\circ} \mathrm{e}$ $3^{\circ}$ da Portaria Intersecretarial 115/15 - SF.

Percebe-se que a Portaria Intersecretarial se olvidou de prever os Conselhos de Políticas Públicas, de caráter deliberativo, especialmente os incumbidos de administrar Fundo Especial, na composição do referido Grupo de Planejamento para a elaboração da proposta orçamentária anual.

Sob o ponto de vista da articulação administrativa, entendemos que os Conselhos de Políticas Públicas, de caráter deliberativo, exercem a função de órgão setorial conjuntamente com a Secretaria Municipal em cuja estrutura administrativa estejam inseridos.

\footnotetext{
${ }^{80}$ Programa informatizado chamado de "Módulo de Planejamento Orçamentário do Sistema de Orçamento e Finanças - SOF"'.

${ }^{81}$ Informação obtida no portal eletrônico da Prefeitura Municipal de São Paulo. Acessado em: 10/08/15. Disponível em: < http://planejasampa.prefeitura.sp.gov.br/>.
} 
Por exemplo, o plano de aplicação de recursos financeiros do Fundo de Desenvolvimento Urbano - FUNDURB do Município de São Paulo é aprovado por seu Conselho Gestor ${ }^{82}$ e encaminhado, anualmente, anexo à lei orçamentária, para aprovação da Câmara Municipal conforme prevê o artigo 342 da Lei Municipal 16.050, de 31 de julho de 2014.

Nestes casos, tal como exposto anteriormente ${ }^{83}$, mostra-se imprescindível a existência de regras de articulação entre esses órgãos setoriais. Por exemplo, os Conselhos deliberativos precisam ser previstos como órgãos setoriais e, consequentemente, possam constituir, no âmbito dos respectivos Conselhos, Grupo de Planejamento nos termos da Portaria Intersecretarial anual que estabelece o processo de elaboração da proposta orçamentária anual. Tal medida é indispensável para evitar a sobreposição de competências no processo de planejamento e orçamento pelas respectivas Secretarias Municipais e, consequentemente, evitar o esvaziamento das competências conferidas por lei aos Conselhos.

Não se ignora que a proposta orçamentária encaminhada pelo Poder Executivo ainda é submetida ao processo legislativo da Câmara Municipal de São Paulo que, por sua vez, poderá apresentar emendas parlamentares que alterem as dotações orçamentárias previstas na proposta inicial. No entanto, em vista dos limites da presente pesquisa, restringiremos nossa análise à fase administrativa de elaboração da proposta orçamentária no âmbito do Poder Executivo.

\subsection{REGIME FINANCEIRO DOS FUNDOS ESPECIAIS}

Os fundos especiais ${ }^{84}$ são instrumentos financeiros de grande utilidade aos

\footnotetext{
${ }^{82}$ Art. 341. O Fundo de Desenvolvimento Urbano - FUNDURB será administrado por um Conselho Gestor paritário, composto por 10 (dez) membros titulares e respectivos suplentes, assim definidos: I - 5 (cinco) representantes de órgãos do Poder Público; II - 5 (cinco) representantes da sociedade civil, oriundos dos seguintes Conselhos Municipais: a) 2 (dois) representantes do Conselho Municipal de Política Urbana - CMPU; b) 1 (um) representante do Conselho Municipal de Habitação - CMH; c) 1 (um) representante do Conselho Municipal de Trânsito e Transporte - CMTT; d) 1 (um) representante do Conselho Municipal de Meio Ambiente e Desenvolvimento Sustentável - CADES (Plano Diretor Estratégico de São Paulo, Lei 16.050, de 31 de julho de 2014).

${ }^{83}$ Vide tópico 3.3.3.2 Conselhos e processo de planejamento e orçamento segundo a Lei Orgânica do Município de São Paulo.

${ }^{84}$ Os Fundos especiais a que fazemos alusão referem-se aos chamados Fundos contábeis ou de destinação, distinto da modalidade Fundo de participação ou financeiro. A primeira modalidade consiste na reserva e
} 
Conselhos Municipais de Políticas Públicas, especialmente os de caráter deliberativo, uma vez que a reserva de recursos orçamentários para uma determinada política pública, favorece a implementação e continuidade das políticas públicas ao seu cuidado. Por isso, revela-se de grande importância o conhecimento das regras que regem sua gestão.

De acordo com o conceito legal expresso no artigo 71 da Lei 4.320/64, o Fundo especial constitui "o produto de receitas específicas que por lei se vinculam à realização de determinados objetivos ou serviços, facultada a adoção de normas peculiares de aplicação”.

O regime financeiro dos Fundos deveria ser regido por lei complementar, consoante o disposto no artigo 165, §9º inciso II da Constituição Federal. Porém, à míngua da lei complementar, o Supremo Tribunal Federal entende que a Lei 4.320/64, artigos 71 a 74, continuará a cumprir esse papel (ADI-MC 1726/DF, rel. Min. Maurício Corrêa, j. 16.09.1998). No âmbito da União, também incide o regramento do Decreto-Lei 200/67 (NUNES, 2008).

São atributos indispensáveis dos fundos especiais: a) as receitas que compõem o fundo devem ser previstas em lei, porém, não é permitida a vinculação da receita de impostos a fundos, salvo as exceções previstas no artigo 167, inciso IV, da CF; b) vinculação das receitas a finalidades sociais ou econômicas previstas em lei; c) vinculação do fundo a órgão da administração direta - esse atributo está relacionado ao fato de que os entes da administração indireta já possuem personalidade jurídica própria, o que pressupõe autonomia administrativa e financeira. Ademais, os recursos orçamentários já destinados à administração indireta devem ser aplicados em suas atividades-fim, sendo inconveniente a criação de fundo para o mesmo fim; d) aplicação dos recursos de acordo com o plano de aplicação anexo à lei orçamentária, facultada a adoção de normas peculiares de aplicação no âmbito da unidade gestora. Por isso costuma-se dizer que o fundo se vincula a órgão da administração direta, a qual, apesar de não possuir autonomia financeira, pode contar com o Fundo para promover as políticas públicas a seu cuidado. De todo modo, o art. $165, \S 5^{\circ}, \mathrm{I}$, da Constituição Federal dispõe que o orçamento dos fundos é distinto dos entes da administração direta e indireta - isso significa que os recursos do Fundo não se misturam com os recursos da unidade gestora, pois os recursos do fundo são identificados por contas e códigos próprios (NUNES, 2008).

Como se vê, os Fundos correspondem a um conjunto de recursos financeiros

utilização de recursos para determinada finalidade legal, enquanto a segunda modalidade, de caráter tributário, diz respeito à reserva de recursos para repartição entre pessoas jurídicas determinadas (OLIVEIRA, 2008; NUNES, 2008). 
vinculados às atividades de interesse social ou econômico do Poder Público, podendo ser constituídos de recursos orçamentários e extraorçamentários, inclusive a receita própria, mas sua criação deverá ser precedida de autorização legislativa (CF, artigo 167, inciso IX). Como meros lançamentos fiscais, não titularizam interesses nem obrigações, muito menos praticam atos jurídicos. Portanto, não possuem personalidade jurídica, vinculando-se sempre a um órgão da administração para a consecução de suas finalidades. Regis Fernandes de Oliveira entende que os Fundos especiais também não possuem personalidade judiciária, isto é, não poderiam figurar no polo ativo ou passivo de uma ação judicial. Para o autor, qualquer malversação de seus recursos e consequências daí advindas deve ser imputada ao respectivo órgão gestor, jamais ao Fundo. No entanto, reconhece o autor, a doutrina majoritária inclinase por reconhecer personalidade judiciária ao Fundo, a exemplo das chamadas "universalidades jurídicas" herança jacente, condomínio, a massa falida, o espólio etc. (OLIVEIRA, 2008).

Em se tratando de um Fundo vinculado a um Conselho Municipal de Política Pública, deve-se observar que:

\begin{abstract}
Os recursos dos Fundos são administrados segundo a política definida pelos respectivos Conselhos que integram o orçamento do município. Estão entre as atribuições dos Conselhos em relação aos Fundos: elaboração do plano de aplicação dos recursos, o qual será submetido pelo prefeito à apreciação do Poder Legislativo; estabelecimento dos parâmetros técnicos e as diretrizes para a aplicação dos recursos; acompanhamento e avaliação da execução, desempenho e resultados financeiros do Fundo; mobilização dos diversos segmentos da sociedade no planejamento, execução e controle das ações do Fundo; fiscalização dos programas desenvolvidos com recursos do Fundo; e publicação de todas as resoluções do Conselho referentes ao Fundo em periódicos de grande circulação no município ou afixação em local de fácil acesso à população (MARTINS et. all., 2008, p. 171-172).
\end{abstract}

Do excerto acima se pode depreender que a vinculação de um Fundo Especial a um Conselho não é, ou não deveria ser, meramente formal. Ao contrário, implica na atribuição de um grande leque de responsabilidades imprescindíveis à gestão eficaz de seus recursos. Envolve todas as etapas de uma política pública, desde a definição das diretrizes e parâmetros técnicos necessários à sua formulação, passando pelo acompanhamento de sua implementação até a avaliação de seus resultados.

Dentre as vantagens de criação de fundos especiais, podemos citar que: a) a alocação de receitas à determinada finalidade protege a implementação da política pública das vulnerabilidades orçamentárias; b) existe a possibilidade de se adotarem normas 
especiais de execução orçamentária sem as amarras do orçamento fiscal ordinário (art. 71, parte final, da Lei 4.320/64); c) a existência de uma unidade gestora do fundo favorece que a política pública tenha um começo, meio e fim, conferindo maior eficiência à atividade administrativa; d) de maneira excepcional, os recursos transferidos ao fundo não retornam ao erário ao final do exercício, garantindo a suficiência de recursos para as despesas, ainda que executadas no ano seguinte (NUNES, 2008).

Há, no entanto, desvantagens na criação de fundos especiais, como, por exemplo: a) a individualização dos recursos e a existência de uma unidade gestora do fundo, aumentam os gastos contábeis e administrativos; b) paradoxalmente, eventual destinação excessiva de recursos financeiros aos fundos poderá comprometer a implementação de demandas prioritárias da Administração Pública (NUNES, 2008).

Embora a Lei 4.320/64 possibilite que a flexibilização da execução orçamentária dos Fundos - por exemplo, no tocante ao regime de aplicação de recursos e de prestação e tomada de contas dos Fundos, as despesas e receitas dos fundos devem ser previstas nas leis orçamentárias $^{85}$ aplicando-lhes integralmente os princípios orçamentários da anualidade, unidade, universalidade e da especificação ${ }^{86}$.

Isso leva à conclusão de que os fundos, na maioria das vezes, consistem, efetivamente, em rubricas orçamentárias que, apesar de admitirem regras específicas de execução do orçamento (art. 71, parte final), não se divorciam dos processos de elaboração e cumprimento do orçamento público (NUNES, 2008, p. 218).

Portanto, toda autorização de despesa com recursos do fundo deve obedecer às dotações previstas na lei orçamentária anual e no plano de aplicação do Fundo (art. 72 da Lei 4.320/64), sem prejuízo do controle externo desempenhado pelo Tribunal de Contas ou órgão equivalente (art. 74 da Lei 4.320/64) (OLIVEIRA, 2008).

O presente capítulo chega ao fim com diversas contribuições para a compreensão da participação dos Conselhos no processo orçamentário municipal de São Paulo, tais como: a) os Conselhos se apresentam como espaço de discussão privilegiado no ciclo de formação da política pública; b) os instrumentos legais de planejamento e orçamento previstos no artigo 165 da Constituição Federal, o PPA, a LDO e a LOA podem ser considerados expressões jurídicas das políticas públicas, por excelência; b) os Conselhos devem participar

\footnotetext{
${ }^{85}$ Constituição Federal, artigo $65, \S 1^{\circ}$, inciso I e Lei Federal $4.320 / 64$, no art. $2^{\circ}$, $\S 2^{\circ}$, inciso I.

${ }^{86}$ Para consulta acerca dos princípios orçamentários da anualidade, unidade, universalidade e especificação, vide tópico 4.4 Princípios orçamentários.
} 
obrigatoriamente do processo orçamentário municipal (PDE, PPA, LDO, LOA) segundo o disposto nos artigos $8^{\circ}$ e $9^{\circ}$ da LOMSP; c) existe uma relação de sucessiva complementariedade entre o PDE, o PPA, a LDO e a LOA, a fim de que o planejamento de longo prazo ajuste-se aos planejamentos de médio e curto prazo das políticas públicas; d) os procedimentos administrativos internos dos Conselhos devem observar os requisitos materiais e os prazos orçamentários previstos na LOMSP; e) a ausência de participação dos Conselhos deliberativos, na condição de órgão setorial, no processo orçamentário anual (LDO e LOA) ou quadrianual (PPA), instituído pela Secretaria Municipal de Finanças e Desenvolvimento Econômico (SF), invalida a proposta orçamentária aprovada na parte relativa aos Conselhos; f) o regime financeiro dos Fundos Especiais também se submete aos princípios orçamentários da unidade, da universalidade, da especificação, da anualidade, da transparência e da gestão democrática das cidades. Os recursos dos Fundos são destinados a uma finalidade especial e eventual saldo remanescente permanece no Fundo de um exercício para o outro. Em relação à execução orçamentária, poderá haver regras especiais previstas em lei, desde que observadas as diretrizes, metas, objetivos e plano de aplicação de recursos previstos na LOA.

No próximo capítulo, com base nos referenciais teóricos construídos até o momento, averiguaremos o desenho e dinâmica dos procedimentos administrativos do $\mathrm{CMH}$ de acordo com as garantias processuais dos conselheiros, bem como se, e de que modo, o $\mathrm{CMH}$ tem participado do processo orçamentário municipal de São Paulo, e, em caso negativo, entender suas possíveis causas. 


\section{ESTUDO DE CASO: O PROCESSO ORÇAMENTÁRIO MUNICIPAL E OS PROCEDIMENTOS ADMINISTRATIVOS DO CMH}

Antes que seja possível verificar a adequação dos procedimentos administrativos que regem o $\mathrm{CMH}$ ao regime jurídico dos procedimentos administrativos aplicáveis aos Conselhos e analisar a participação do próprio $\mathrm{CMH}$ no processo orçamentário municipal de São Paulo, ambos objetivos específicos da pesquisa, faz-se necessário conhecer a estrutura organizacional, a distribuição de competências legais e eventuais conflitos entre os órgãos internos do $\mathrm{CMH}$, comentados a seguir.

\subsection{ESTRUTURA ORGANIZACIONAL E COMPETÊNCIAS DO CMH}

\subsubsection{Conselho Municipal de Habitação (órgão pleno)}

O artigo 168 da Lei Orgânica do Município de São Paulo (LOMSP) dispõe que "a política municipal de habitação deverá prever a articulação e integração das ações do Poder Público e a participação popular das comunidades organizadas através de suas entidades representativas, bem como os instrumentos institucionais e financeiros para sua execução".

A fim de regulamentar o dispositivo citado, a Lei Municipal 13.425/02 instituiu, no âmbito da Secretaria de Habitação e Desenvolvimento Social de São Paulo - SEHAB, o Conselho Municipal de Habitação de São Paulo - CMH, composto da reunião ordinária de seus 48 (quarenta e oito) membros, dentre os quais 13 (treze) representam o Poder Executivo Municipal, 2 (dois), o Poder Executivo Estadual, 1 (um), a Caixa Econômica Federal, 16 (dezesseis), os movimentos de moradia e os outros 16 (dezesseis) membros, a sociedade civil $\operatorname{organizada}^{87}$.

Os membros do Conselho e de sua Comissão Executiva são escolhidos para um mandato de dois anos ${ }^{88}$ mediante indicação dos representantes do Poder Público e eleição

\footnotetext{
${ }^{87}$ Artigo $5^{\circ}$ da Lei Municipal 13.425/02.
}

${ }^{88}$ Art. $9^{\circ}$ da Lei Municipal 13.425/02. 
dos representantes dos movimentos de moradia. Em relação aos representantes da sociedade civil $^{89}$, a legislação não é clara quanto ao processo de escolha. Enquanto o art. 10 da Lei Municipal 13.425/02 dispõe que os representantes da sociedade civil serão eleitos ${ }^{90}$; o artigo 5 , inciso $\mathrm{V}$, da mesma lei, faz referência à eleição direta apenas dos representantes dos movimentos de moradia. Em vista da imprecisão da lei e do Regimento Interno do CMH, não se sabe quem deve se submeter à eleição direita, universal e facultativa: se apenas os representantes dos movimentos populares ou também dos representantes da sociedade civil.

Segundo a Portaria $n^{\circ}$ 368/SEHAB/2013, que instituiu a Comissão Eleitoral do CMH para o biênio 2014-2016, "os conselheiros arrolados no inciso V [movimentos de moradia] serão eleitos de forma direta e os dos incisos VI e XIV [sociedade civil] serão indicados" (comentário ausente no original). Nestes termos, o procedimento de escolha dos representantes da sociedade civil consiste na abertura de cadastramento de entidades interessadas em participar do $\mathrm{CMH}$. Cumpridos os requisitos legais e, não havendo concorrência, a entidade é nomeada à respectiva vaga. Quando haja mais de uma entidade concorrente da mesma categoria, abre-se pleito eleitoral específico e restrito às pessoas vinculadas às respectivas categoriais (sindicatos, universidades, assessorias de moradia etc. $)^{91}$. A situação é distinta no Conselho Municipal de Política Urbana (CMPU), criado pelo atual Plano Diretor Estratégico de São Paulo, o qual dispõe expressamente sobre a necessidade de eleição direta, universal e facultativa tanto dos representantes dos movimentos populares quanto dos representantes da sociedade civil (ONGs, Igrejas, entidades profissionais etc. $)^{92}$.

\footnotetext{
${ }^{89}$ O critério para conceituar "sociedade civil", adotado pelo Regimento Interno do CMH (2003), é negativo, ou seja, excluídos os representantes do poder público, das entidades comunitárias e das organizações populares (movimentos de moradia), as entidades descritas no artigo $5^{\circ}$, incisos VI a XIV, da Lei 13.425/02, quais sejam: VI - 2 (dois) representantes de universidades ligados à área habitacional; VII - 2 (dois) representantes de entidades de profissionais da área habitacional; VIII - 1 (um) representante de entidades sindicais dos trabalhadores da construção civil; IX - 3 (três) representantes das associações ou sindicatos patronais da cadeia produtiva da indústria da construção civil, existentes no Município; X - 2 (dois) representantes de entidades que prestam assessoria técnica na área habitacional; XI - 2 (dois) representantes de centrais sindicais ; XII - 2 (dois) representantes de ONGs que atuam na área habitacional; XIII - 1 (um) representante de conselho de categoria profissional da área habitacional; XIV - 1 (um) representante de conselho de categoria profissional do direito.

${ }^{90}$ Lei Municipal 13.425/02 “Art. 10 - Os membros do Conselho e sua Comissão Executiva serão nomeados pelo Prefeito do Município de São Paulo, através de decreto, mediante indicação dos representantes do Poder Público e após a eleição dos representantes da sociedade civil" (destaque nosso).

${ }^{91}$ Portaria no 368/SEHAB/2013, publicada no Diário Oficial da Cidade de São Paulo (DOCSP) em 19 de outubro de 2013, ano 58, n. 200, p. 24.

${ }^{92}$ Plano Diretor Estratégico do Município de São Paulo (2014-2024), Lei 16.050, de 31 de julho de 2014, art. $327, \S 1^{\circ} \mathrm{O}$ CMPU será composto por 60 (sessenta) membros titulares e respectivos suplentes, representantes do Poder Público e da sociedade civil, organizados por segmentos, com direito a voz e voto, a saber: [...] II 34 (trinta e quatro) membros da sociedade civil, distribuídos da seguinte forma: [...] b) 4 (quatro) membros representantes dos movimentos de moradia; c) 4 (quatro) membros representantes de associações de bairros;
} 
Em que pese o entendimento do Poder Executivo Municipal, pensamos que a eleição direta, universal e facultativa dos representantes da sociedade civil (movimentos populares e sociedade civil), a exemplo do CMPU, expressa melhor o princípio democrático que rege os Conselhos Municipais de Políticas Públicas e, portanto, não deve se restringir aos movimentos de moradia.

O Conselho bem como sua Comissão Executiva são presididos pelo Secretário de Habitação, cargo nato, competindo-lhe: a) convocar e presidir as reuniões do Conselho; b) promover ou praticar atos de gestão administrativa, necessários ao desempenho das atividades do Conselho, de suas Comissões Temáticas e Grupos de Trabalho; c) emitir voto de desempate, entre outras funções ${ }^{93}$.

A Lei Municipal 13.425/02 atribui ao Conselho competência para estabelecer, acompanhar, controlar e avaliar a política municipal de Habitação de Interesse Social $\mathrm{HIS}^{94}$, bem como supervisionar a gestão dos recursos vinculados ao Fundo Municipal de Habitação - FMH, criado pela Lei Municipal 11.632/94. Em relação às atribuições citadas nos artigos $3^{\circ}$ e $4^{\mathrm{o}}$ da lei ${ }^{95}$, importante identificar e diferenciar a natureza deliberativa,

d) 4 (quatro) membros representantes do setor empresarial, sendo no mínimo 1 (um) da indústria, 1 (um) do comércio e 1 (um) de serviços; e) 1 (um) membro representante dos trabalhadores, por suas entidades sindicais; f) 1 (um) membro de ONGs; g) 1 (um) membro de entidades profissionais; h) 2 (dois) membros de entidades acadêmicas e de pesquisa; i) 2 (dois) membros representantes de movimentos ambientalistas; j) 1 (um) membro representante de movimentos de mobilidade urbana; $\mathrm{k}$ ) 1 (um) membro representante de movimentos culturais; 1) 1 (um) membro representante de entidades religiosas; [...] $\S 7^{\circ}$ Para eleição dos representantes relacionados nas alíneas " $b$ " a "l" do inciso II deste artigo, será garantido direito a voto a todo e qualquer cidadão com título eleitoral, sem necessidade de pré-cadastramento (destaque nosso). Loc. cit.

93 Art. $7^{\circ}$ da Lei Municipal 13.425/02.

${ }^{94}$ Segundo o vigente Plano Diretor Estratégico da cidade de São Paulo, Habitação de Interesse Social (HIS) é "aquela destinada ao atendimento habitacional das famílias de baixa renda, podendo ser de promoção pública ou privada, tendo no máximo um sanitário e uma vaga de garagem, e classificando-se em dois tipos: a) HIS 1: destinada a famílias com renda familiar mensal de até $\mathrm{R} \$ 2.172,00$ (dois mil, cento e setenta e dois reais) ou renda per capita de até $\mathrm{R} \$ 362,00$ (trezentos e sessenta e dois reais); b) HIS 2: destinada a famílias com renda familiar mensal superior a $\mathrm{R} \$ 2.172,00$ (dois mil, cento e setenta e dois reais) ou 362,00 (trezentos e sessenta e dois reais) per capita e igual ou inferior a $\mathrm{R} \$ 4.344,00$ (quatro mil, trezentos e quarenta e quatro reais) ou R\$ 724,00 (setecentos e vinte e quatro reais) per capita" (Lei 16.050, de 31 de julho de 2014, Anexo Quadro 1. Definições).

95 Lei Municipal 13.425/02 - “Art. $3^{\text {o }}$ - Compete ao Conselho Municipal de Habitação: I - participar da elaboração e fiscalizar a implementação dos planos e programas da política habitacional de interesse social, deliberando sobre suas diretrizes, estratégias e prioridades; II - acompanhar e avaliar a gestão econômica, social e financeira dos recursos e o desempenho dos programas e projetos aprovados; III participar da elaboração de plano de aplicação dos recursos oriundos dos Governos Federal, Estadual, Municipal ou repassados por meio de convênios internacionais e consignados na SEHAB; IV - fiscalizar a movimentação dos recursos financeiros consignados para os programas habitacionais; V - constituir grupos técnicos, comissões especiais, temporárias ou permanentes, quando julgar necessário para o desempenho de suas funções; [...]

$\mathrm{X}$ - estabelecer relações com os órgãos, conselhos e fóruns municipais afectos à elaboração do orçamento Municipal e à definição da política urbana; XI - elaborar, aprovar e emendar o seu Regimento Interno; XII - articular-se com as demais instâncias de participação popular do Município; XIII - definir os critérios de atendimento de acordo com base nas diferentes realidades e problemas que envolvam a questão habitacional no Município. Art. $4^{\circ}$ - O Conselho Municipal de Habitação supervisionará o Fundo Municipal 
consultiva ou fiscalizatória de cada atribuição.

O Conselho possui competência deliberativa, plena e conclusiva ${ }^{96}$ para: a) estabelecer as diretrizes, estratégias e prioridades da política habitacional de interesse social - HIS - art. $3^{\circ}$, inciso I; b) estabelecer critérios de atendimento da demanda habitacional art. $3^{\circ}$, inciso XIII; c) elaborar, aprovar e encaminhar a proposta orçamentária anual do FMH, inclusive, quanto às diretrizes, programas de alocação de recursos do FMH e de seu plano de metas - art. $4^{\circ}$, incisos I e II; d) aprovar/rejeitar a prestação de contas do FMH - art. $4^{\circ}$, inciso III, dentre outras.

Aliás, ainda que as Resoluções do Conselho, num primeiro momento, sujeitem-se à homologação do Secretário Municipal de Habitação, em caso negativo, vimos que poderão ser confirmadas, soberanamente, pela maioria absoluta dos conselheiros, portanto, gerando uma condição vinculatória para toda a Administração Pública, inclusive para o Chefe do Poder Executivo.

O colegiado possui ainda competência consultiva quanto ao processo de elaboração do plano de aplicação de recursos para HIS oriundos dos Governos Federal, Estadual, Municipal ou repassados por meio de convênios internacionais consignados no orçamento da SEHAB - art. $3^{\circ}$, inciso III.

A função consultiva confere ao Conselho a prerrogativa de ser necessariamente consultado antes da tomada de decisão pelo Poder Executivo sempre que a decisão envolver políticas públicas de sua competência.

Do acima exposto, podemos perceber que o Conselho (órgão pleno) exerce funções, precipuamente, de planejamento da política pública habitacional, de elaboração e aprovação das propostas orçamentárias envolvendo recursos do Fundo Municipal de Habitação e participação na elaboração das políticas públicas para HIS sob a responsabilidade da SEHAB.

O CMH não possui competência legal para implementar a política habitacional. Importante não confundir com a função de acompanhamento, fiscalização ou monitoramento

de Habitação, competindo-lhe especificamente: I - estabelecer as diretrizes e os programas de alocação dos recursos do Fundo Municipal de Habitação, de acordo com os critérios definidos na Lei no 11.632/94, em consonância com a política municipal de habitação; II - encaminhar e aprovar, anualmente, a proposta de orçamento do FMH e de seu plano de metas; III - aprovar as contas do Fundo antes de seu envio aos órgãos de controle interno; IV - dirimir dúvidas quanto à aplicação das diretrizes e normas relativas ao FMH nas matérias de sua competência; V - definir normas, procedimentos e condições operacionais; VI - fixar a remuneração do órgão operador do FMH; Parágrafo único - Para a função específica de acompanhamento da gestão do Fundo Municipal de Habitação será designada um a Comissão Executiva do Conselho, formada a partir dos seus membros" (destaque nosso).

${ }^{96}$ Art. 16 da Lei 13.425/02. 
na fase de execução da política habitacional, esta sim atribuída ao Conselho. Nesta, como já dissemos, o CMH exercerá competência decisória sobre as operações implementadas pela COHAB-SP no que concerne à observância das diretrizes, metas e plano de aplicação de recursos previstos na lei orçamentária anual do FMH e demais Resoluções do CMH.

Como se vê, o Conselho (órgão pleno) é órgão colegiado de deliberação plena e conclusiva sobre a fase de elaboração da política pública habitacional e da proposta orçamentária anual do FMH, sendo parte legítima ainda no processo de elaboração da proposta orçamentária para Habitação de Interesse Social em relação aos recursos consignados na SEHAB.

Contudo, a trajetória política do Conselho tem revelado que o Conselho não tem participado da elaboração do plano de aplicação dos recursos para HIS consignados no orçamento da SEHAB; nem da elaboração ou aprovação da proposta orçamentária anual do $\mathrm{FMH}^{97}$, o que, em última instância, fica sujeito à impugnação administrativa ou judicial das referidas propostas orçamentárias por violação ao princípio da legalidade (art. $9^{\circ}$ da LOM e $\operatorname{artigos} 3^{\circ}$ e $4^{\circ}$ da Lei Municipal 13.425/02 $)^{98}$.

Na fase de execução orçamentária, o Conselho conta com o auxílio da Comissão Executiva tratada a seguir.

\subsubsection{Comissão Executiva}

A função específica de acompanhamento ou fiscalização da gestão do FMH é exercida por uma Comissão Executiva, composta de membros do Conselho, entre os quais 3 (três) são representantes do Poder Executivo Municipal; 3 (três), representantes dos movimentos de moradia e 3 (três), representantes da sociedade civil, sendo que a presidência nata cabe ao Secretário Municipal de Habitação ${ }^{99}$.

Como órgão de controle interno, por meio de sua Comissão Executiva ${ }^{100}$, o Conselho possui a atribuição de fiscalizar a política pública de HIS executada pela SEHAB

\footnotetext{
${ }^{97}$ Cf. 5.4 Análise e discussão dos dados.

${ }^{98}$ Nesse sentido, conferir o tópico 4.3 Conselhos e processo orçamentário municipal segundo a Lei Orgânica do Município de São Paulo.

${ }^{99}$ Lei Municipal 13.425/02, artigo $3^{\circ}, \S 1^{\circ}$ e $7^{\circ}$.

${ }^{100}$ Lei Municipal 13.425/02, art. $3^{\circ}$, inciso I e II.
} 
e a gestão econômica, social e financeira do FMH, notadamente em relação às operações ${ }^{101}$ ou projetos implementados pela Companhia Metropolitana de Habitação de São Paulo COHAB-SP, este, como agente operador e executor do Fundo ${ }^{102}$.

De acordo com o artigo $3^{\circ}$ do Regimento Interno da Comissão Executiva ${ }^{103}$, durante a execução orçamentária, compete ao órgão: a) acompanhar o desenvolvimento dos projetos e ações contemplados nos programas; b) apreciar as adequações necessárias nos projetos e ações em andamento que envolvam alocação de recursos adicionais; c) apreciar os atos " $a d$ referendum" do Secretário Municipal de Habitação que digam respeito à gestão dos programas e projetos do $\mathrm{FMH}$; d) apreciar as propostas orçamentárias do FMH a serem submetidos ao $\mathrm{CMH}$; e) apreciar as contas do $\mathrm{FMH}$ previamente ao $\mathrm{CMH}$; f) propor e/ou apreciar procedimentos e adequações necessárias ao desenvolvimento dos projetos e ações.

Contudo, a trajetória de vida do Conselho ${ }^{104}$ revela que a Comissão Executiva tem exercido funções tipicamente de gestão operacional do Fundo ao invés de atuar como órgão fiscalizador, supervisionando, acompanhando e monitorando a implementação das políticas públicas previstas na LOA com recursos do FMH. Como ato de gestão operacional, a Comissão Executiva, e não o Secretário Municipal de Habitação, tem deliberado sobre as propostas de operações (projetos, atividades e ações concretas) a serem implementadas pela COHAB-SP com recursos do FMH, ao contrário do que prevê os artigos $5^{\circ}$, inciso $\mathrm{X}$, e $6^{\circ}$, inciso IV da Lei Municipal 11.632/94 ${ }^{105}$. Esta questão será analisada com maior profundidade mais à frente ${ }^{106}$.

Talvez a Comissão Executiva esteja exercendo atos de gestão pelo fato de o

\footnotetext{
${ }^{101}$ Art. $3^{\circ}, \S 3^{\circ}$, art. $6^{\circ}, \S 1^{\circ}$ e art. 19 , inciso VIII, ambos, do Regimento Interno do CMH (2003).

102 Art. $6^{\circ}$ da Lei Municipal 11.632/94 - "Art. $6^{\circ}$ - Caberão à COHAB/SP, enquanto órgão operador, as seguintes atribuições, além das já estabelecidas em lei e nos seus estatutos: I - Implementar a Política Municipal de Habitação em consonância com as metas e prioridades estabelecidas pela Secretaria da Habitação e Desenvolvimento Urbano - SEHAB e aprovadas pelo Conselho; II - Executar programas e projetos derivados da Política Municipal de Habitação, estabelecidos em conformidade com o disposto na presente lei; [...]".

${ }^{103}$ Cf. $2^{\text {a }}$ Gestão (2005 a 2007), Ata da $3^{\text {a }}$ Reunião Ordinária da CECMH, realizada em 30 de agosto de 2006. Contudo o texto literal do Regimento Interno consta de versão integral não publicada no DOCSP, obtida diretamente nos arquivos da Secretaria Executiva do $\mathrm{CMH}$, vinculada à SEHAB. Para ter acesso ao texto, vide ANEXO A - Atas de reunião não localizadas no DOCSP, mas disponibilizadas pela Secretaria Executiva do $\mathrm{CMH}$ em formato ".doc" (Microsoft Word).

${ }^{104}$ Vide 5.4 Análise e discussão dos dados.

${ }^{105}$ Cf. Lei Municipal 11.632/94 - "Art. $5^{\circ}$ - Além das já estabelecidas em lei, são atribuições da Secretaria Municipal da Habitação e Desenvolvimento Urbano - SEHAB: [...]X- Aprovar as operações a s erem contratadas com recursos do Fundo Municipal de Habitação, observadas as diretrizes do Conselho do Fundo". Art. $6^{\circ}$ - Caberão à COHAB/SP, enquanto órgão operador, as seguintes atribuições, além das já estabelecidas em lei e nos seus estatutos: [...] IV - Viabilizar as operações consideradas tecnicamente viáveis e previam ente aprovadas pela Secretaria da Habitação e Desenvolvimento Urbano - SEHAB, responsabilizando-se por todo o processo de produção, pelo acompanhamento da execução e comercialização (destaque nosso).

${ }^{106}$ Cf. 5.2 Regime financeiro do FMH.
} 
Conselho não ter elaborado nem aprovado nenhuma proposta orçamentária anual do FMH nem o plano de aplicação de recursos, ao contrário do que prescreve o artigo $4^{\circ}$, incisos I e II da Lei Municipal 13.425/02, o que tornaria irregular (nula) qualquer implementação (execução) de políticas habitacionais com recursos do FMH sem a aprovação prévia do Conselho. A hipótese levantada se corrobora com aprovação ${ }^{107}$ do plano de aplicação de recursos do FMH para 2015 pelo Conselho, em pleno exercício financeiro, o qual deveria ter sido aprovado e anexado à proposta orçamentária no ano anterior, nos termos do artigo $2^{\circ}, \S 2^{\circ}$, inciso I, da Lei 4.320/64. Ou seja, ao que tudo indica, a fim de convalidar o plano de aplicação do FMH não aprovado tempestivamente pelo Conselho, o Poder Executivo tem submetido à aprovação da Comissão Executiva as propostas de operações a serem implementadas pela COHAB-SP com recursos do FMH.

Do acima exposto, verificamos que, em tese, a Comissão Executiva possui funções de consulta ao Conselho (órgão pleno) tanto em relação à proposta orçamentária do FMH quanto à prestação de contas do FMH, reservando-se a competência deliberativa ao órgão pleno. A respeito da execução orçamentária, vimos que a Lei Municipal 13.425/02 conferiu à Comissão competências próprias de acompanhamento, fiscalização e monitoramento da gestão econômica, social e financeira do Fundo. Para o desempenho de suas funções, o Conselho e a Comissão executiva têm o apoio administrativo da Secretaria Executiva, cujas atribuições serão analisadas a seguir.

\subsubsection{Secretaria Executiva}

O apoio técnico e administrativo ao CMH fica a cargo de sua Secretaria Executiva, exercida pela Superintendência de Habitação Popular - HABI, vinculada à SEHAB, que por sua vez conta com o apoio de técnicos da COHAB-SP e da SEHAB ${ }^{108}$.

Dentre outras competências, cabe à Secretaria Executiva: a) levantar e sistematizar informações que permitam ao Conselho estabelecer as diretrizes e aprovar os programas de alocação dos recursos do Fundo, bem como acompanhar e avaliar os ganhos sociais e o desempenho dos programas e projetos aprovados; b) tomar as providências necessárias junto à SEHAB e à COHAB-SP a fim de garantir a emissão de relatórios de acompanhamento da

${ }^{107}$ Cf. $5^{\text {a }}$ Gestão (2014 a 2016), Ata da $4^{\text {a }}$ Reunião Ordinária do CMH, realizada em 22 de janeiro de 2015.

108 Art. 15 da Lei 13.425/02 e artigo 19 do Regimento Interno do CMH (2003). 
movimentação dos recursos do Fundo e do desempenho dos programas, nos prazos estabelecidos pelo Conselho. Para esse fim, a Secretaria deve disponibilizar informações aos conselheiros a qualquer momento, inclusive dando-lhes vista ou extraindo cópias dos processos administrativos e documentos arquivados no órgão, bem como dar suporte técnico, administrativo e financeiro aos Grupos de Trabalho e aos conselheiros, e garantir a contratação de serviços externos quando necessários ${ }^{109}$.

\subsubsection{Grupos de Trabalho}

Os Grupos de Trabalho - GTs atuam como órgão instrutório do Conselho, por tempo indeterminado ou por prazo certo, têm o objetivo de realizar atividades de pesquisa, estudo, análise, proposição, elaboração ou acompanhamento de temas relacionados à HIS. Seu funcionamento (composição, periodicidade, procedimento) foi variável ${ }^{110}$ até a aprovação de seu Regimento Interno em $2010^{111}$.

Desde então, os Grupos de Trabalho são compostos de 06 (seis) conselheiros no mínimo; sendo obrigatória a presença de, ao menos, um representante de cada categoria: poder público, movimentos de moradia e sociedade civil. Dentre os membros, são nomeados um coordenador, um coordenador adjunto e um relator para presidir e coordenar o desenvolvimento dos trabalhos. É permitida a participação de pessoas com conhecimentos específicos que não sejam conselheiras, desde que contem com a concordância da maioria de seus membros. Quando o membro do GT não comparecer a duas reuniões consecutivas, sem apresentar justificativa, será excluído do Grupo, devendo ser substituído por outro da mesma categoria. Caso não haja o mínimo de participantes exigido pelo Regimento Interno, o GT deve ser encerrado ${ }^{112}$.

Desde a $1^{\text {a }}$ Gestão (2003 a 2005) até a gestão atual (2014-2016) ${ }^{113}$, observamos o frequente requerimento de maiores informações, esclarecimentos ou diligências antes da votação. Isto porque boa parte dos votos tem sido apresentada sem a realização de etapa

\footnotetext{
${ }^{109}$ Art. $9^{\circ}$ do Regimento Interno dos Grupos de Trabalho do CMH aprovado pela Resolução CMH n $^{\circ} 44$, de 13 de abril de 2010. Publicado no DOCSP em 14 de maio de 2010, ano 55, n. 89, p. 50-51.

${ }^{110}$ Cf. 5.4 Análise e discussão dos dados.

${ }^{111}$ Regimento Interno dos Grupos de Trabalho do CMH.

112 Art. $7^{\circ}, \$^{\circ}$ do Regimento Interno dos Grupos de Trabalho do CMH.

${ }^{113}$ Cf. 5.4 Análise e discussão dos dados.
} 
instrutória nos GTs. E, ainda assim, boa parte dos votos tem sido colocada em votação, pela mesa diretora, sem o acolhimento do pedido de informações ou diligências.

\subsection{CONFLITO DE COMPETÊNCIAS ENTRE O CONSELHO E SUA COMISSÃO EXECUTIVA}

Na prática ${ }^{114}$, o Poder Executivo Municipal tem entendido que o acompanhamento (fiscalização) da gestão do FMH sobre as matérias elencadas no artigo $4^{\circ}$ da Lei 13.425/02 teriam sido conferidas exclusivamente à Comissão Executiva em detrimento da apreciação final pelo Conselho ${ }^{115}$. Por isso, a Comissão Executiva tem decidido conclusivamente sobre a prestação de contas do $\mathrm{FMH}$, embora se cuide de atribuição exclusiva do órgão pleno conforme prevê o Regimento Interno da Comissão Executiva.

Com efeito, o termo "supervisão" previsto no "caput" do artigo $4^{\circ}$ da Lei Municipal 13.425/02 (ver nota acima) é ambíguo ao abranger matérias de naturezas distintas. Enquanto a competência de elaborar e aprovar a proposta orçamentária do FMH se insere na fase de elaboração da política pública, a prestação de contas da gestão do FMH se insere na fase de execução orçamentária. Nos termos do parágrafo único do supracitado dispositivo legal, entendemos que apenas as funções específicas de acompanhamento ou de fiscalização da gestão do FMH poderiam ser exercidas pela Comissão Executiva.

Qualquer extensão da competência do Conselho à Comissão Executiva exige disposição expressa em lei específica, inexistente no caso, e eventual ato de delegação da competência do Conselho, por se tratar de órgão colegiado, encontra vedação expressa no artigo 15, "caput" e incisos I, III e V da LPAM. ${ }^{116}$ No mesmo sentido, a título de exemplo,

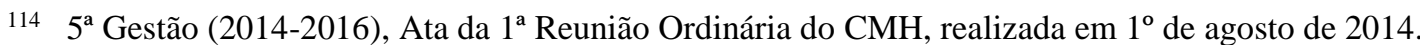

115 Art. $4^{\circ}$ - O Conselho Municipal de Habitação supervisionará o Fundo Municipal de Habitação, competindolhe especificamente:

I - estabelecer as diretrizes e os programas de alocação dos recursos do Fundo Municipal de Habitação, de acordo com os critérios definidos na Lei $n^{\circ}$ 11.632/94, em consonância com a política municipal de habitação; II - encaminhar e aprovar, anualmente, a proposta de orçamento do FMH e de seu plano de metas;

III - aprovar as contas do Fundo antes de seu envio aos órgãos de controle interno;

IV - dirimir dúvidas quanto à aplicação das diretrizes e normas relativas ao FMH nas matérias de sua competência;

$\mathrm{V}$ - definir normas, procedimentos e condições operacionais;

VI - fixar a remuneração do órgão operador do FMH;

VII - divulgar no Diário Oficial do Município as decisões, análises das contas do FMH e pareceres emitidos.

Parágrafo único - Para a função específica de acompanhamento da gestão do Fundo Municipal de Habitação será designada uma Comissão Executiva do Conselho, formada a partir dos seus membros.

${ }^{116}$ Lei Municipal 14.141/06 - Art. 15. A competência é irrenunciável e exercida pelo agente público a que foi 
a Lei de Processo Administrativo Estadual de São Paulo igualmente prevê que as competências essenciais do órgão, que justifiquem sua existência, são indelegáveis, como é o caso da elaboração e aprovação da proposta orçamentária do FMH e a tomada de contas do FMH pelo Conselho.

Considerando que o Conselho é órgão de deliberação plena e conclusiva nos termos do artigo 16 da mesma lei, adotamos a posição de que o Conselho permanece como órgão superior de decisão final sobre a prestação de contas do FMH e, até que se efetive a participação do Conselho no processo de elaboração e aprovação da proposta orçamentária anual do FMH, o Conselho deve ter a prerrogativa de gerir os recursos do FMH, sob pena de esvaziar as competências do órgão pleno.

\subsection{NORMAS PROCEDIMENTAIS}

\subsubsection{Procedimentos administrativos ${ }^{117}$}

Neste tópico, verificaremos a adequação dos procedimentos administrativos que regem o $\mathrm{CMH}$ ao regime jurídico dos procedimentos administrativos aplicáveis aos Conselhos, o qual representa o primeiro objetivo específico desta pesquisa.

Os procedimentos administrativos do CMH se desenvolvem basicamente por meio de dois mecanismos: $1^{\circ}$ ) por discussão e deliberação pelo Conselho ou Comissão Executiva; $2^{\circ}$ ) pela atividade desempenhada pelos grupos de trabalho (GTs), temporários ou permanentes.

As solicitações de voto encaminhadas ao Conselho devem conter enunciado sucinto do objeto da pretensão, histórico ou justificativa do pleito, minuta de resolução e, se for o caso, anexo contendo parecer técnico e outras informações pertinentes. Elas devem ser encaminhadas à Secretaria Executiva do $\mathrm{CMH}$ com antecedência mínima de 15 (quinze) dias

atribuída como própria, salvo os casos de delegação e avocação legalmente admitidos. Parágrafo único. Não podem ser objeto de delegação: I - a edição de atos de caráter normativo; II - a decisão de recursos administrativos; III - as matérias de competência exclusiva do órgão ou autoridade; IV - as atribuições recebidas por delegação, salvo autorização expressa e na forma por ela determinada; V - as funções dos órgãos colegiados.

117 Pela expressão "procedimentos administrativos" devem-se entender os procedimentos administrativos internos do CMH essenciais à função de planejamento e orçamento municipal. 
para inclusão na pauta da reunião ordinária subsequente. As solicitações de voto devem, então, ser reencaminhas para os conselheiros com antecedência mínima de 10 (dez) dias junto com a ata da reunião anterior e a pauta da reunião seguinte e, em avulso, os documentos relativos às matérias objeto da pauta.

Deve-se acrescentar que o Regimento Interno do CMH não prevê a autuação de cada solicitação de voto, isto é, a formação dos autos processuais propriamente ditos, o que prejudica sensivelmente a juntada de novas manifestações, documentos e provas. Além disso, o Regimento não se prevê a oportunidade de manifestação ou juntada de documentos antes da reunião ordinária de votação.

Sobre isso, poder-se-ia dizer que os conselheiros têm o direito de se manifestar verbalmente e juntar documentos durante a própria reunião e que isso seria o bastante para o exercício do direito de defesa. Porém, deve-se considerar que a juntada de informação escrita ou de documento na própria reunião inviabiliza seu conhecimento imediato pelos conselheiros antes da votação.

Por isso, a apresentação de alegações escritas e juntada de documentos antes da reunião ordinária deve ser garantida; ou que o procedimento administrativo preveja o direito de vista do processo pelos conselheiros, suspendendo a votação até a próxima reunião.

Solução, esta, adotada pelo Conselho Municipal de Saúde de São Paulo, vejamos:

II - Ao início da discussão poderá ser pedido vistas, devendo o assunto retornar impreterivelmente na reunião ordinária seguinte para apreciação e votação, mesmo que este direito seja exercido por mais de 01 Conselheiro. O Conselheiro que pediu vistas será o relator, no caso de mais de um conselheiro pedir vistas, haverá tantos relatores quanto os pedidos de vista. A todo pedido de vista deve corresponder um parecer técnico, por escrito, previamente apresentado aos Conselheiros. Os pareceres deverão ser colocados em votação um a um, obedecida a ordem de solicitação de $\operatorname{vistas}^{118}$.

Tal como exposto acima, quando documentos forem juntados na reunião ordinária, entendemos que a solicitação de vista, antes da votação, é direito subjetivo de todos os conselheiros, sob pena de violar as garantias constitucionais (art. $5^{\circ}, \mathrm{LV}$ ) do contraditório e da ampla defesa. Nesse sentido, segue a doutrina de Sérgio Ferraz e Adilson de Abreu Dallari (2012) e de Eduardo Gárcia de Enterría e Tomás-Ramón Fernández (2014) ${ }^{119}$.

\footnotetext{
${ }^{118}$ Regimento Interno do Conselho Municipal de Saúde de São Paulo (SÃO PAULO, 2000), artigo 14, inciso II.

${ }^{119}$ Para maiores detalhes, remeto o leitor aos tópicos 3.3.4 Princípios do contraditório e da ampla defesa; 3.4.1 Instauração; 3.4.2 Instrução.
} 
O quórum de instalação das reuniões é de no mínimo de $1 / 3$ de seus integrantes ${ }^{120}$ e as decisões são tomadas com aprovação da maioria simples de seus membros ${ }^{121}$. Nas reuniões ordinárias, antes de proceder à deliberação, os conselheiros podem fazer uso da palavra seguindo-se a ordem de inscrição, cuja coordenação cabe à mesa diretora, presidida pelo Secretário Municipal de Habitação, na função de presidente do CMH, com o apoio da Secretaria Executiva.

O Regimento Interno (CMH, 2003) dispõe que apenas os conselheiros possuem direto à voz; porém, o mesmo direito deve ser estendido às pessoas ou grupos potencialmente atingidos pela decisão administrativa, por atuarem no processo como legítimos interessados. A respeito, já tivemos oportunidade de dissertar sobre a procedimentalização da atividade administrativa e sobre a aplicabilidade do princípio do contraditório e da ampla defesa em procedimentos administrativos envolvendo interesses difusos, o que vem sendo aceito por grande parte da doutrina administrativista (MARQUES NETO, 2004; MEDAUAR, 2006) $)^{122}$.

Deste modo, consoante prevê o artigo 14, inciso III, da LPAM, entendemos que a participação no processo administrativo deve ser garantida às organizações ou entidades representativas na defesa de interesses difusos. Além disso, ainda que o objeto do procedimento verse, em regra, sobre políticas públicas, no caso da habitação de interesse social, é comum envolverem áreas e imóveis ocupados irregularmente por famílias que serão diretamente atingidas pela decisão do Conselho. Por isso, a essas famílias deve ser garantido o direito fundamental ao contraditório e ampla defesa de seus direitos e interesses individuais, nos termos do artigo $5^{\circ}$, inciso LV, da Constituição Federal e artigo 14, inciso II, da LPAM.

Quando os interessados requererem a produção de provas ou estudos em geral a fim de sanar dúvida prejudicial à votação, entendemos que o pedido deve ser deliberado imediatamente pela plenária. Sendo favorável, a votação deve ser suspensa até a conclusão da fase instrutória. Ao seu final, o resultado dos trabalhos, autuado ao processo administrativo, deve ser apresentado em forma de relatório, reincluindo-se a solicitação de voto na pauta conforme o procedimento padrão. Salvo previsão em contrário, o procedimento previsto para o $\mathrm{CMH}$, aplica-se às reuniões ordinárias da Comissão Executiva

\footnotetext{
${ }^{120}$ Art. 11 da Lei 13.425/02.

121 Art. 12 da Lei 13.425/02.

122 Para mais esclarecimentos remeto o leitor aos tópicos 3.1 A procedimentalização da atividade administrativa, 3.3.4 Princípio do contraditório e da ampla defesa e 3.4.1 Instauração e 3.4.2 Instrução.
} 
e dos Grupos de Trabalho.

Deve-se observar ainda que nem a lei instituidora nem o Regimento Interno do Conselho preveem a realização de audiências públicas de prestação de contas à sociedade, experiência, esta, instituída no CMDCA de São Paulo como já abordamos anteriormente ${ }^{123}$, necessária para o permanente rejuvenescimento do vínculo do $\mathrm{CMH}$ com a sociedade e com suas entidades de origem, de onde provém sua legitimidade institucional. Logo, a ausência de previsão ou de realização de audiências públicas de prestação de contas pelo Conselho é um fator desabonador de seu funcionamento (TATAGIBA, 2010).

Segundo a Lei Municipal 13.425/02, artigo 13, as deliberações do CMH se materializam na forma de Resolução, posteriormente submetida à homologação do Secretário Municipal de Habitação no prazo de 15 (quinze) dias. Em caso negativo, a Resolução deve retornar ao Conselho, com prioridade, para discussão na próxima reunião, quando será confirmada ou reformulada pela maioria absoluta dos conselheiros. Embora a lei não especifique, o Regimento Interno do $\mathrm{CMH}\left(2003\right.$, art. $14, \S 1^{\circ}$ e $\left.\S 5^{\circ}\right)$ define que as deliberações normativas se materializarão na forma de Resoluções e que as demais terão registro específico na Secretaria Executiva do Conselho. O mesmo Regimento Interno (art. $14, \S 3^{\circ}$ ) ainda prevê que a deliberação que confirma a Resolução é soberana, sendo subsequentemente encaminhada para publicação.

Em outras palavras, tratando-se de competência decisória prevista em lei e inscrita na fase decisória do processo administrativo, a deliberação do $\mathrm{CMH}$ vincula a vontade do Secretário ou do Prefeito Municipal, conforme já expuseram Gustavo Justino de Oliveira (1997; 2005), Diogo de Figueiredo Moreira Neto (1992; 1997), Laura Mendes Amando de Barros (2012), entre outros ${ }^{124}$.

Quando se trate de Minuta de Instrução Normativa, a competência de aprovação é do Presidente do Conselho Municipal de Habitação, conforme previsto no art. 15 do Regimento Interno do Conselho Municipal de Habitação.

Segundo o Regimento Interno dos Grupos de Trabalho (GTs) ${ }^{125}$, estes devem se reunir, no mínimo, a cada dois meses por convocação do seu Coordenador, por meio eletrônico, pela Secretaria Executiva do Conselho, informando data, hora e o local da reunião.

\footnotetext{
${ }^{123}$ Vide tópico 3.4.2 Instrução.

${ }^{124}$ Para maiores detalhes, vide o tópico 2.4 Natureza Jurídica, atribuições e discricionariedade dos Conselhos Municipais de Políticas Públicas.

${ }^{125}$ Regimento interno dos Grupos de Trabalho do CMH.
} 
As reuniões do GT se instalam com o quórum mínimo de 3 (três) de seus integrantes, considerando inclusive o Coordenador, que deverá presidir a reunião ou, na sua ausência, o Coordenador Adjunto. Quando necessário, poderá haver reuniões especiais com setores de atividade econômica e da sociedade civil sobre questões pertinentes aos temas em discussão, sobre o que o relator nomeado deverá elaborar o Relatório Preliminar e Final.

Os membros do GT deverão receber a pauta e os documentos relativos às matérias objeto da futura reunião com no mínimo três dias da data de sua realização, bem como a ata da reunião anterior. O GT deve apresentar à plenária do $\mathrm{CMH}$ relatórios com os resultados de seus trabalhos, contendo minuta de resolução, parecer ou histórico detalhado de suas atividades até dois meses antes do encerramento do mandato ${ }^{126}$.

Cabe à SEHAB e à Secretaria Executiva do Conselho dar suporte técnico, administrativo e financeiro aos Grupos de Trabalho, e garantir a contratação de serviços externos quando necessários. Os recursos para a realização dos serviços e das despesas que forem necessárias devem ser solicitados à Secretaria Executiva do $\mathrm{CMH}$ que, por sua vez, requisitará reserva de recursos à $\mathrm{COHAB}-\mathrm{SP}$, como agente operadora dos recursos do $\mathrm{FMH}$. Por fim, as atas das reuniões, após sua aprovação, devem ser publicadas no Diário Oficial da Cidade de São Paulo - DOCSP.

Conclusivamente, ao não preverem a autuação das peças e documentos que instruem a solicitação de voto; e não haver previsão de apresentação de informações e documentos contrapostos pelos demais conselheiros antes da reunião ordinária, o procedimento administrativo do Conselho e de suas Comissões Internas deixa de observar os princípios do devido processo legal, da igualdade processual, do contraditório e da ampla defesa $^{127}$, ensejando-lhe impugnação em sede administrativa ou judicial. Daí a necessidade de aprimoramento dos respectivos Regimentos Internos.

\footnotetext{
${ }^{126}$ Art. $8, \S 3^{\circ}$ do Regimento Interno dos Grupos de Trabalho do CMH.

${ }^{127}$ Cf. tópicos 3.3.2 Princípio da igualdade, impessoalidade ou imparcialidade, 3.3.4 Princípio do contraditório e da ampla defesa e 3.4.1 Instauração.
} 


\subsubsection{Processo orçamentário municipal ${ }^{128}$}

Neste tópico, analisaremos a participação do próprio $\mathrm{CMH}$ no processo orçamentário municipal de São Paulo, o qual consiste no segundo objetivo específico desta pesquisa. Vejamos.

A Lei Orgânica do Município de São Paulo - LOMSP, artigo 9, prevê que a "Lei disporá sobre: I - o modo de participação dos Conselhos, bem como das associações representativas, no processo de planejamento municipal e, em especial, na elaboração do Plano Diretor, do Plano Plurianual, das diretrizes orçamentárias e do orçamento anual”.

Já vimos que cabe ao CMH: a) participar da elaboração do plano de aplicação dos recursos para HIS oriundos dos Governos Federal, Estadual, Municipal ou repassados por meio de convênios internacionais e consignados na SEHAB e, b) encaminhar e aprovar, anualmente, a proposta de orçamento do FMH e de seu plano de metas. Contudo, já dissemos que o Conselho não tem exercido as competências supracitadas. ${ }^{129}$

Uma de suas causas pode decorrer da falta de articulação e coordenação entre os órgãos públicos municipais e o CMH. Uma vez que o processo orçamentário do Município de São Paulo - instaurado pelas Portarias Intersecretariais em $2013^{130}, 2014^{131}$ e $2015^{132}$ não inclui o CMH entre os órgãos setoriais encarregados da elaboração do PPA, LDO e LOA referente ao FMH.

De acordo com as referidas Portarias, a atividade de elaboração da proposta orçamentária deveria envolver a Secretaria Municipal de Finanças e Desenvolvimento Econômico - SF (órgão central do orçamento), o CMH (órgão setorial do orçamento) e a COHAB-SP (unidade orçamentária e administrativa), enquanto agente operador do Fundo e responsável pela implementação de seus projetos e atividades ${ }^{133}$. Procedimentos, estes, já analisados no capítulo anterior ${ }^{134}$.

Nesse sentido, caberia à SF informar ao Conselho os parâmetros orçamentários

\footnotetext{
128 Pela expressão "processo orçamentário municipal" nos referimos aos procedimentos de articulação e coordenação entre os diversos órgãos públicos municipais envolvidos no processo de planejamento e elaboração dos planos, programas e propostas orçamentárias do Município de São Paulo.

${ }^{129}$ Vide 5.4 Análise e discussão dos dados.

${ }^{130}$ Portaria Intersecretarial 04/13 - SEMPLA/SF, publicada no DOCSP em 29 de junho de 2013, ano 58, p. 01.

${ }^{131}$ Portaria Intersecretarial 03/14 - SEMPLA/SF, publicada no DOCSP em 18 de junho de 2014, ano 59, n. 112.

132 Portaria Intersecretarial 115/15 - SF, publicada no DOCSP em 20 de junho de 2015, ano 60, p. 113.

${ }^{133}$ Art. $6^{\circ}$ da Lei Municipal 11.632/94.

${ }^{134}$ Ver 4.5.4 Normas procedimentais.
} 
(previsão de recursos) disponíveis para o exercício seguinte, com base nos quais o Conselho definiria as diretrizes, programas, metas e parâmetros orçamentários a serem observados pela COHAB-SP (unidade orçamentária) para a elaboração da proposta orçamentária setorial, isto é, dos projetos, das atividades e do plano de aplicação dos recursos do FMH. Próximo passo, a COHAB-SP remeteria a proposta setorial ao Conselho para validação e consolidação (CONTI, 2008; GIACOMONI, 2012; BRASIL, 2014).

Daí a proposta setorial seria encaminhada à SF para consolidação e validação da proposta orçamentária municipal a ser encaminhada à Câmara Municipal, à semelhança do esquema apresentado a seguir:

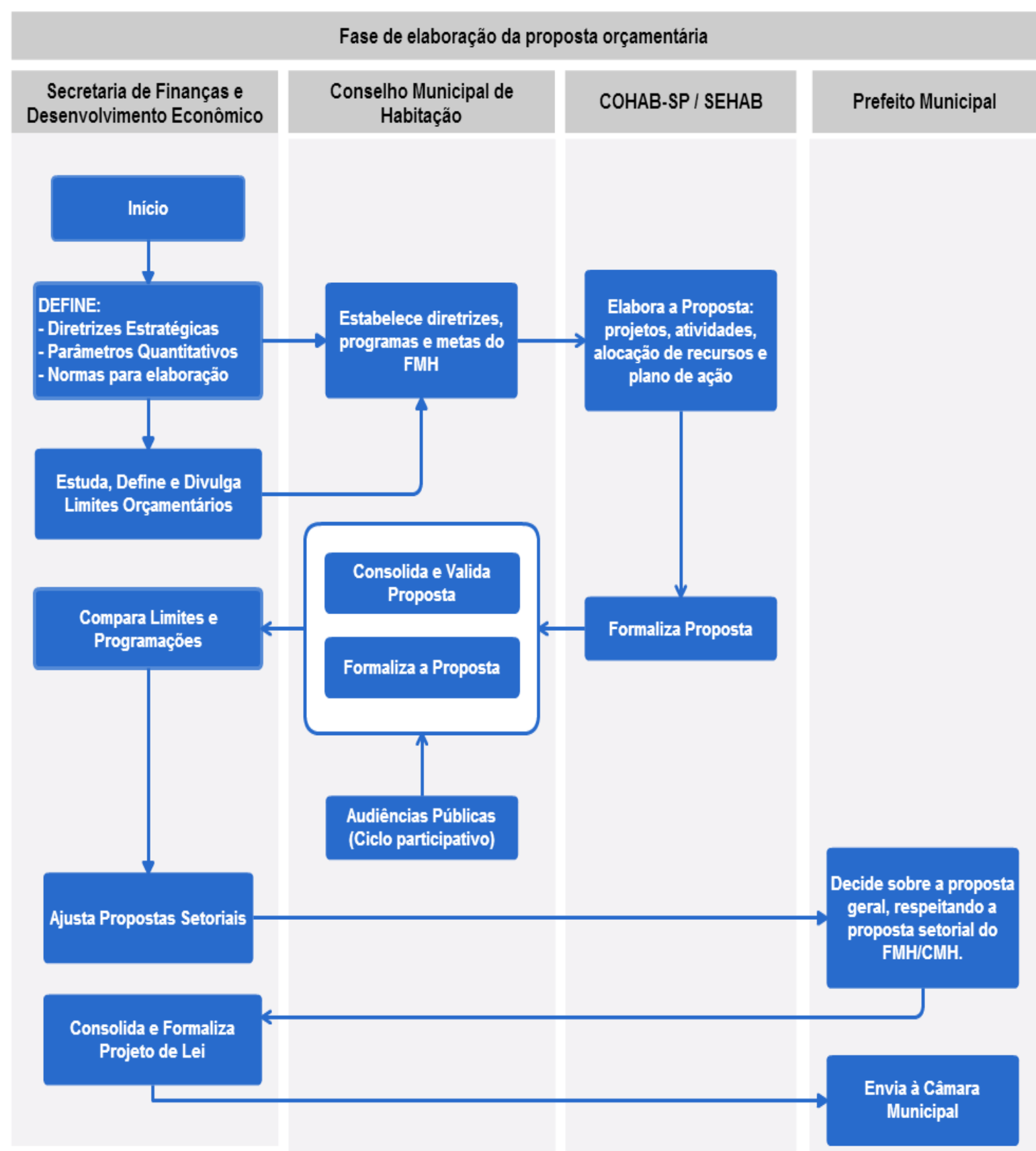

Esquema 2 - Participação do CMH na fase de elaboração da proposta orçamentária. 
Fonte: Adaptado do Manual Técnico de Orçamento - MTO, Ministério do Planejamento e Orçamento - MPOG (BRASIL, 2014).

Ainda que a Lei Municipal 13.425/02 não tenha disposto sobre o "modo de participação" do Conselho no processo orçamentário, não se justifica a omissão supracitada, tendo a Administração Pública Municipal o dever de proceder à articulação e à coordenação administrativa entre os órgãos públicos municipais e o $\mathrm{CMH}$, sob pena de tonar as respectivas peças orçamentárias inválidas, por infração ao princípio da legalidade (art. $9^{\circ} \mathrm{da}$ LOM e $\operatorname{artigos} 3^{\circ}$ e $4^{\circ}$ da Lei Municipal 13.425/02).

Em relação à execução orçamentária, quem teria a atribuição de apresentar e de aprovar as propostas de operações a serem contratadas com recursos do FMH?

Como já vimos, a resposta encontra-se nos artigos $5^{\circ}$, inciso $\mathrm{X}$, e $6^{\circ}$, inciso IV da Lei Municipal 11.632/94, que disciplina o regime financeiro do FMH, o qual prevê que caberá à SEHAB aprovar as operações a serem contratadas com recursos do Fundo Municipal de Habitação, observadas as diretrizes do CMH.

No entanto, o Regimento Interno do CMH (2003) é ambíguo. Ao mesmo tempo em que confere ao Secretário Municipal de Habitação a prerrogativa de aprovar as propostas de operações ${ }^{135}$, prevê que caberá à Comissão Executiva apreciar os atos "ad referendum" que digam respeito à gestão dos Programas e Projetos do FMH, na primeira reunião após a realização do ato. ${ }^{136}$ De qualquer modo, o Regimento Interno não poderá se sobrepor ou conflitar com o disposto em norma superior, a Lei 11.632/94.

Daí o porquê, a única exegese válida é a de que compete à Comissão Executiva fiscalizar se as operações apresentadas pela COHAB-SP e aprovadas pelo Secretário de Habitação respeitam as diretrizes da LOA referente ao Fundo e demais diretrizes do Conselho.

Na prática, porém, as operações têm sido propostas pelos conselheiros e submetidas à aprovação da Comissão Executiva do $\mathrm{CMH}$.

Advertimos que o objeto do procedimento administrativo do Conselho requer especialização e racionalização: a) ou o Conselho se encarrega da fase de planejamento e de elaboração das políticas públicas por meio das peças orçamentárias (PPA, LDO e LOA) e da fiscalização sobre a gestão do Fundo, tal como previsto na Lei Municipal 13.425/02; b) ou se encarrega da elaboração de ações concretas (operações) próprias da fase de execução

${ }^{135}$ Art. 19, inciso VIII, do Regimento Interno do CMH (2003).

136 Art. $6^{\circ}, \S 1^{\circ}$ do Regimento Interno do CMH (2003). 
do orçamento, ou de implementação da política pública habitacional, obviamente, desde que a supracitada lei seja alterada conferindo esta competência ao $\mathrm{CMH}$.

O escopo das atividades é consideravelmente distinto. Enquanto a primeira exige a realização de diagnósticos, definição de metas, de diretrizes, de programas de ação e de plano de aplicação de recursos - "mais gerais"; a fase de implementação requer aprofundado conhecimento técnico, por exemplo, em engenharia, administração, contabilidade etc. "mais específico", atribuições incompatíveis com a vocação institucional do Conselho.

Tal como dispõe a lei, as propostas de operações (projetos e atividades) elaboradas pela COHAB-SP ou SEHAB devem ser aprovadas pelo Secretário de Habitação e depois apreciadas (fiscalizadas) pela Comissão Executiva quanto ao respectivo enquadramento nas diretrizes, metas, programas e plano de aplicação previstos na lei orçamentária anual do FMH e demais diretrizes do CMH.

Deste modo, no exercício legal de sua função fiscalizatória, caso encontre irregularidades nas operações poderá determinar a suspensão de sua execução para as adequações que se fizerem necessárias. Em todo o caso, cabe à Comissão Executiva e/ou Conselho acompanhar e fiscalizar sua execução e, após sua conclusão, avaliar o atingimento das metas previamente estipuladas.

No que concerne à prestação de contas e à proposta orçamentária relativas do FMH, cabe à Comissão Executiva apreciá-las previamente ao Conselho (órgão pleno) conforme prevê o artigo $3^{\circ}$ do Regimento Interno da Comissão Executiva ${ }^{137}$, o qual, com base no parecer apresentado pela Comissão, delibera plena e conclusivamente. No entanto, como já expusemos, a presente pesquisa verificou que a Comissão Executiva tem deliberado sobre as contas do FMH, o que tem gerado, neste aspecto, conflito de competências entre os órgãos ${ }^{138}$.

A fim de elucidar o exposto, ver o diagrama a seguir:

Esquema 3 - Participação do CMH na fase de execução orçamentária.

${ }^{137}$ Cf. $2^{\text {a }}$ Gestão (2005 a 2009), Ata da $3^{\text {a }}$ Reunião Ordinária da CECMH, realizada em 30 de agosto de 2006.

138 5.2 Conflito de competências entre o Conselho e sua Comissão Executiva. 


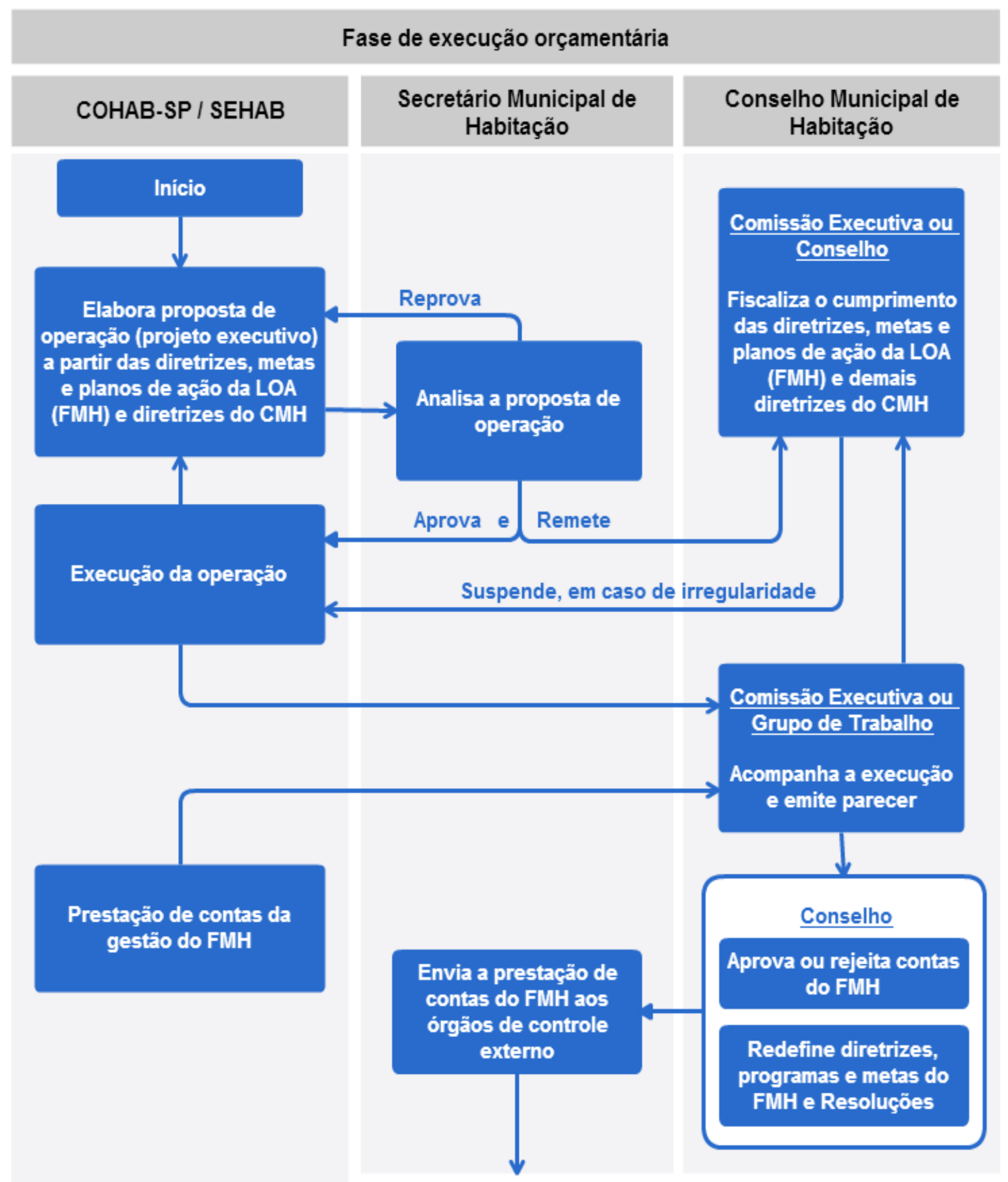

Fonte: elaboração própria.

Como visto, os procedimentos internos e externos do $\mathrm{CMH}$ ainda requerem aperfeiçoamentos a fim de garantir: a) adequado direito à informação, ao contraditório e ampla defesa dos interessados, inclusive quanto à fase instrutória do procedimento, b) melhor definição dos procedimentos e das competências dos órgãos envolvidos no planejamento e elaboração da proposta orçamentária e no acompanhamento da execução orçamentária. 


\subsection{ANÁLISE E DISCUSSÃO DOS DADOS}

Neste tópico, procederemos à análise temática dos dados colhidos nas Atas de Reunião do CMH de 2003 a 2015 ${ }^{139}$, a fim de descrever tendências no contexto dos debates; identificar as intenções, características e os apelos dos conselheiros; bem como registrar a evolução dos procedimentos na trajetória do Conselho.

Após a coleta e organização do material a ser analisado, realizou-se a leitura flutuante das atas, nas cinco gestões do CMH de 2003 a 2015. E, em seguida, orientado pelos objetivos específicos da pesquisa e pelo referencial teórico construído nos capítulos precedentes, procedemos à escolha das unidades de significação de análise, as quais foram sistematizadas nas seguintes categorias ou temas (MARTINS, 2008; BARDIN, 2009):

a) "Participação do Conselho no processo orçamentário municipal": a partir desta categoria procuramos selecionar e analisar os debates envolvendo a participação do Conselho na discussão, elaboração e aprovação das diversas peças orçamentárias (PPA, LDO e LOA) em confronto com o referencial teórico analisado no capítulo 4.

b) "Aspectos instrutórios do procedimento administrativo": a partir desta categoria procuramos selecionar e analisar os debates envolvendo as fases de instrução do procedimento administrativo do Conselho em confronto com o referencial teórico analisado no capítulo 3.

Importante ressaltar, desde já, que a análise das atas não abordou as políticas habitacionais em si, o que não significa desmerecer a importância de seu estudo, muito pelo contrário. No entanto, devido ao escopo do presente trabalho, eminentemente processual ou procedimental, optamos por averiguar as categorias ou temas citados acima ${ }^{140}$.

Nossa primeira análise se concentrará na categoria "Participação do Conselho no processo orçamentário municipal”, comentada a seguir.

\footnotetext{
${ }^{139}$ Cf. APÊNDICE A - Lista das atas de reunião analisadas.

${ }^{140}$ Em relação às políticas habitacionais de São Paulo desenvolvidas até 2007 - ex.: Morar no Centro, Locação Social, Programa de Arrendamento Residencial (PAR), Bolsa-Aluguel, Intervenções em cortiços, Urbanização de Favelas, Regularização Fundiária, Mutirões, Mananciais entre outas - sugerimos a leitura da pesquisa "Habitação: controle social e política pública", elaborada pelo Observatório dos Direitos do Cidadão, vinculado ao Instituto Pólis e à Pontifícia Universidade Católica de São Paulo - PUC-SP (CYMBALISTA et. all, 2007).
} 


\subsubsection{Participação do Conselho no processo orçamentário municipal ${ }^{141}$}

Como vimos anteriormente, as propostas orçamentárias (PPA, LDO e LOA) da SEHAB para HIS devem contar com a participação do CMH em sua elaboração e; as propostas orçamentárias (PPA, LDO e LOA) do FMH devem ser elaboradas e aprovadas pelo CMH nos termos da Lei Municipal 13.425/02. No entanto, a análise das atas de reunião do Conselho (órgão pleno) e de sua Comissão Executiva no período de 2003 até 2015 demonstraram que as referidas peças orçamentárias não contaram com a participação do Conselho em sua elaboração e aprovação, conforme observaremos à frente.

Tanto em $2003^{142}$ quanto em $2004^{143}$, o Poder Público apresentou as propostas orçamentárias respectivas ao Conselho dias antes de seu envio à Câmara Municipal e, mesmo assim, não foram submetidas à aprovação do $\mathrm{CMH}$ como determina o $\operatorname{artigo~} 4^{\circ}$, inciso II da Lei Municipal 13.425/02.

Nesse sentido, a conselheira Maria Lucia Martins, representante da Faculdade de Arquitetura e Urbanismo (FAU) da USP, apresentou relatório final de suas atividades como conselheira observando que, durante a $1^{\text {a }}$ Gestão (2003 a 2005), a participação do Conselho foi insuficiente em relação à alocação de recursos e à definição dos beneficiários dos programas habitacionais. ${ }^{144}$

Em 2004, segundo ano de funcionamento do $\mathrm{CMH}$, buscou-se estabelecer uma política pública para habitações precárias multifamiliares, também chamadas de cortiços. Ao invés do CMH formular a política em um GT interno, constituiu-se uma comissão integrada por conselheiros do $\mathrm{CMH}$ e técnicos da SEHAB para formulação daquela política pública. Como resultado, o Conselho aprovou a Resolução CMH n 15, de 07 de dezembro de 2004, chamada "Programa de Cortiços - Reabilitação da Moradia Coletiva". Considerada satisfatória pelos conselheiros, a plenária recomendou a continuidade da Comissão mista para aperfeiçoamento do programa ${ }^{145}$.

Ressaltando os benefícios do trabalho conjunto entre os conselheiros e técnicos da

\footnotetext{
141 Pela expressão "processo orçamentário municipal" nos referimos aos procedimentos de articulação e coordenação entre os diversos órgãos públicos municipais envolvidos no processo de planejamento e elaboração dos planos, programas e propostas orçamentárias do Município de São Paulo.

$1421^{\text {a }}$ Gestão (2003 a 2005), Ata da $1^{\text {a }}$ Reunião Extraordinária do CMH, realizada em 24 de setembro de 2003.

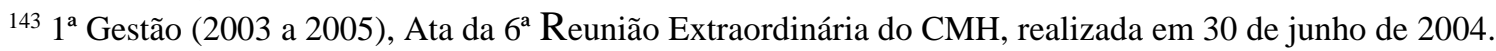

144 Relatório da gestão 2003-2005 do CMH, representação da Universidade / FAUUSP, Titular: Maria Lucia Refinetti Martins (MARTINS, 2005).

$1451^{\text {a }}$ Gestão (2003-2005), Ata da $8^{\text {a }}$ Reunião Ordinária do CMH, realizada em 07 de dezembro de 2004.
} 
Administração, o então Secretário Municipal da SEHAB, o Sr. Orlando de Almeida Filho, apresentou ao $\mathrm{CMH}$ os órgãos e departamentos da SEHAB e respectivos responsáveis, bem como da Superintendência de Habitação Popular - HABI (HABI Norte, HABI Sul, HABI Sudeste, Centro, Sudeste e Leste), colocando-os à disposição para desenvolvimento de políticas habitacionais ${ }^{146}$.

A articulação dos órgãos municipais na elaboração do "Programa de Cortiços" tornou-se referência para o desenvolvimento de futuras políticas habitacionais pelo Conselho, o que se mostra de acordo com a articulação administrativa proposta por Miguel Sánchez Móron (1980) e Maria Coeli Simões Pires (2010) como condição de eficácia de instituições participativas, a exemplo dos Conselhos ${ }^{147}$.

Na $2^{\text {a }}$ Gestão (2005 a 2007), o Poder Público incluiu, por equívoco, a proposta orçamentária do FMH de 2007 na pauta de votação do Conselho e, por isso, logo em seguida, retirou-a de pauta ${ }^{148}$ conforme se depreende das falas ${ }^{149}$ a seguir ${ }^{150}$ :

Sr. Ortega Marques (poder público) - Faz uma correção inicial, que a Secretaria Executiva cometeu um lapso na pauta da reunião, o $13^{\circ}$ item será suprimido, porque está escrito: orçamento 2007 solicitação de voto, portanto não tem sentido porque não se pode aprovar algo que não está ao seu alcance (grifo nosso).

Sra. Vera Alvarenga (sociedade civil) - E pede um esclarecimento, por que não se votaria a aprovação da proposta orçamentária de 2007 , que tem a ver com o Fundo Municipal da Habitação, se isso não é objeto de aprovação do Conselho Municipal? (grifo nosso).

Sra. Elisabete França (poder público) - explica que o $13^{\circ}$ entrou por equívoco, e que a votação do orçamento é da atribuição daqueles que são eleitos para tal, que são os Vereadores, que agora é uma peça da Câmara dos Vereadores (grifo nosso).

Sra. Luciana Bedeschi (sociedade civil) - com relação à pauta, pede para registrar que acha impreciso a Secretaria do Conselho e o Conselho não conhecerem a proposta orçamentária para 2007, que ela foi apresentada para a Executiva, mas não foi apresentada para o Conselho e acha que isso foi uma imprecisão deste Conselho (grifo nosso).

Sobre esse episódio, pedimos atenção à declaração feita pelo Sr. Ortega Marques, Presidente da COHAB-SP, de que "não se pode aprovar algo que não está ao seu alcance",

\footnotetext{
$1461^{\text {a }}$ Gestão (2003-2005), Ata da 9a Reunião Ordinária do CMH, realizada em 23 de março de 2005.

${ }^{147}$ Maiores detalhes, vide os tópicos 4.3 Conselhos e processo orçamentário municipal segundo a Lei Orgânica do Município de São Paulo e

${ }^{148}$ Maiores detalhes sobre o processo orçamentário municipal, ver tópicos “4.5.3 Leis orçamentárias" e "4.5.4 Normas procedimentais".

149 Devido ao grande número de erros de gramática (ortografia, regência, concordância etc.), optamos, propositadamente, por não indicar tais erros ("sic") a fim de não descaracterizar a identidade dos discursos, não sobrecarregar o texto e não prejudicar ainda mais a clareza da leitura.

$1502^{\text {a }}$ Gestão (2005-2007), Ata da 5 ${ }^{\text {a }}$ Reunião Ordinária do CMH, realizada em 28 de setembro de 2006. As citações são literais, respeitando-se a oralidade dos falantes.
} 
referindo-se à inclusão da proposta orçamentária do FMH para 2007, na pauta de votação do $\mathrm{CMH}$.

A afirmação da Sra. Elisabete França, Superintendente de Habitação Popular, também merece destaque: "o $13^{\circ}$ [item da pauta] entrou por equívoco, e que a votação do orçamento é da atribuição daqueles que são eleitos para tal, que são os Vereadores".

$\mathrm{Na}$ verdade, equivocados estavam os representantes do Poder Público, pois vimos que competia ao CMH encaminhar e aprovar a proposta de orçamento do FMH e seu plano de metas nos termos expressos do artigo $4^{\circ}$, inciso II, da Lei Municipal 13.425/02. Não obstante, a proposta orçamentária foi retirada de pauta pela mesa diretora ${ }^{151}$.

Analisando a trajetória do CMH entre 2003 e 2007, Renato Cymbalista e outros (2007) ressaltaram que:

As atas secas, diretas, mais formais, mostram a ausência do debate. O governo constrói a agenda da política, informa ao conselho sobre programas e projetos em implementação e se submete, quando necessário, a um processo de aprovação de suas propostas, no qual, via de regra, não encontra muitas resistências. Ou seja, nessa fase o conflito se reduz, assim como a capacidade de proposição do conselho (CYMBALISTA et. all., 2007, p. 108-109).

Nossa análise corrobora o exposto na pesquisa citada, no sentido de que a maior parte das discussões no período analisado se referiram à aprovação de propostas de programas e projetos em implementação (operações) os quais acabaram sendo aprovados pelo Conselho, diversas vezes, sem efetivas resistências de sua plenária - salvo a manifestação de alguns poucos conselheiros.

Na $3^{\text {a }}$ Gestão (2007-2009) do CMH, o Sr. Luiz Kohara, representante da sociedade civil, solicitou, tempestivamente, a apresentação da proposta orçamentária do FMH de 2009 para discussão, aprovação e encaminhamento à Câmara Municipal pelo Conselho ${ }^{152}$. Contudo, a proposta orçamentária não foi apresentada na reunião seguinte. Daí o porquê a conselheira Maria José Carvalho, representante dos movimentos de moradia, reiterou o pedido para que: "nós, Conselheiros, e todos pudéssemos chamar uma reunião extraordinária para que possamos discutir a questão do orçamento para o ano que vem”. Em complemento, a Sra. Tânia Maria Diniz, representante da sociedade civil, solicitou que a proposta fosse encaminhada ao GT de Acompanhamento Orçamentário.

Em que pese o exposto, anotamos que não houve convocação da reunião extraordinária solicitada, nem houve o encaminhamento da proposta orçamentária para o

$1512^{\text {a }}$ Gestão (2005-2007), Ata da 5 ${ }^{\text {a }}$ Reunião Ordinária do CMH, realizada em 28 de setembro de 2006.

$1523^{\text {a }}$ Gestão (2007-2009), Ata da $3^{\mathrm{a}}$ Reunião Ordinária do CMH, realizada em 17 de junho de 2008. 
Grupo de Trabalho especializado no tema ${ }^{153}$.

Na $5^{\text {a }}$ Reunião Ordinária, realizada em 17 de setembro de 2008, houve mais um questionamento quanto à mora do Poder Público em apresentar a proposta orçamentária. Em resposta, o Sr. Secretário Municipal de Habitação, Elton Zacarias, informou que a proposta estava sendo elaborada pela SEHAB e que poderia ser disponibilizada ao Conselho em 30 de setembro, quando finda o prazo de envio da proposta orçamentária à Câmara Municipal. Por isso, a Sr. Evaniza Rodrigues, representante dos movimentos de moradia, advertiu:

Sra. Evaniza Rodrigues (movimento de moradia) - reafirma a importância de o Conselho ser ouvido também em relação à proposta encaminhada para SEMPLA. "E já que SEMPLA tem um representante aqui, também (é importante) que (ele) ouvisse os Conselheiros nas suas considerações, porque senão a gente fica meio assim, a gente vai receber depois quando já o leite foi derramado. Então não adianta, vai ser só uma informação: eu achava importante que apresentasse, a gente discutisse e, aproveitando a presença de SEMPLA, que é Conselheira também, fosse portadora da opinião desse Conselho para considerar a hora de fechar o orçamento" 154 .

A despeito dos requerimentos acima, a proposta orçamentária do FMH não foi apresentada nem aprovada pelo Conselho nas reuniões seguintes antes de ser encaminhada à Câmara Municipal em 30 de setembro, ao contrário do que dispõe a Lei Municipal $13.425 / 02$.

Durante a $4^{\text {a }}$ Gestão (2009 a 2011), as propostas orçamentárias do FMH para 2010 e 2011 sequer foram apresentadas ao Conselho antes de seu envio à Câmara Municipal. O Conselho tomou ciência dos respectivos orçamentos quando já estavam na fase de execução orçamentária. Prática que se repetiu nos anos seguintes.

$\mathrm{Na} 2^{\text {a }}$ Reunião Ordinária do CMH, $4^{\text {a }}$ Gestão (2009-2011), houve a apresentação do Plano Municipal de Habitação Social, que começou a ser elaborado em 2008 por meio de um convênio com a "Cities Alliance", sob a coordenação da arquiteta Tereza Herling junto com a SEHAB ${ }^{155}$. Verificamos que as discussões sobre a revisão do Plano Municipal de Habitação fizeram parte da pauta do Conselho durante toda a sua trajetória, com registros desde $2003^{156}$ e de forma mais acentuada durante a $3^{\text {a157 }}$ e $4^{\text {a }}$ Gestão ${ }^{158}$, inclusive com a

\footnotetext{
$1533^{\text {a }}$ Gestão (2007-2009), Ata da $4^{\text {a }}$ Reunião Ordinária do CMH, realizada em 06 de agosto de 2008.

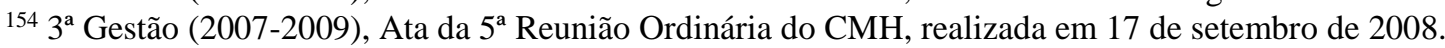

$1554^{\text {a }}$ Gestão (2009-2011), Ata da $2^{\text {a }}$ Reunião Ordinária do CMH, realizada em 18 de março de 2010.

$1561^{\text {a }}$ Gestão (2003-2005), Ata da $1^{\text {a }}$ Reunião Extraordinária do CMH, realizada em 24 de setembro de 2003 e Ata da $3^{\text {a }}$ Reunião Extraordinária do $\mathrm{CMH}$, realizada em 21 de novembro de 2003.

$1573^{\text {a }}$ Gestão (2007-2009), Ata da $2^{\text {a }}$ Reunião Ordinária do CMH, realizada em 19 de março de 2008; Ata da $9^{a}$ Reunião Ordinária do $\mathrm{CMH}$, realizada em 15 de julho de 2009.

$1584^{\text {a }}$ Gestão (2009-2011), Ata da $1^{\text {a }}$ Reunião Ordinária da CECMH, realizada em 23 de fevereiro de 2010; Ata da $4^{\mathrm{a}}$ Reunião Ordinária do $\mathrm{CMH}$, realizada em 16 de setembro de 2010.
} 
instituição de Grupos de Trabalho específicos para sua elaboração/revisão. O projeto do Plano foi encaminhado à Câmara Municipal de São Paulo em 2011, por meio do Projeto de Lei 509/11, de iniciativa do então Prefeito Municipal, Gilberto Kassab. No entanto, tendo sido aprovado em $1^{a}$ discussão, o projeto de lei não teve andamento, sendo ao final retirado de pauta pelo autor em 14 de junho de 2013 e arquivado recentemente em 23 de março de 2015. Não temos notícias sobre as razões de seu arquivamento na CMSP, nem se houve continuidade de sua discussão no CMH ou no Poder Executivo ${ }^{159}$.

No debate a seguir, ganha relevo a questão do planejamento das prioridades do Conselho como pré-requisito de análise do mérito dos projetos a implementar:

Sra. Marly Namur (sociedade civil) - Me incomoda muito quando eu venho aqui, é que estamos sempre votando coisas pontuais. Então fica uma coisa assim, vamos aprovar não sei quantos milhões para fazer tal coisa, o que significa isso em relação ao total que está previsto e o que significa em relação ao que já foi gasto? Quer dizer, fica uma coisa assim muito pontual e pouca esclarecedora, eu me sinto muito desconfortável ${ }^{160}$.

Sr. Kazuo Nakano (sociedade civil) - Estou achando essa discussão extremamente importante e temos que extrair aprendizagens dela, eu acho que esse debate sobre prioridades para utilização dos recursos do Fundo e discutir estratégias para ampliar esses recursos é o debate que esse Conselho deve fazer permanentemente. ${ }^{161}$.

A mesma falta de planejamento do Conselho foi ressaltada pelo conselheiro Roberto Ararê Sennes, representante de sociedade civil, na $6^{\mathrm{a}}$ Reunião Ordinária da $4^{\mathrm{a}}$ Gestão (2009-2011) do CMH, do seguinte modo: “A única coisa que me deixa um pouco desconfortável é nós não termos um planejamento do Fundo. Esses recursos que ele tem hoje, o quanto que nós estamos destinando a essa parceria, isso já podia estar planejado (destaque nosso)". ${ }^{162}$

Tais manifestações evidenciam a necessidade do Conselho se concentrar em atividades próprias da fase de elaboração da proposta orçamentária, momento no qual se formalizam as diretrizes, prioridades e planos estratégicos citados pelos conselheiros. Somente então as operações aprovadas pelo Secretário Municipal poderão se sujeitar às prioridades e diretrizes previamente aprovadas pelo Conselho.

Entre 2011 e 2013, o mandato dos conselheiros foi interrompido em vista de irregularidades no processo eleitoral, suspenso judicialmente; o que restou regularizado entre

\footnotetext{
159 Para maiores informações sobre a tramitação do Projeto de Lei 509/11 junto à CMSP, acessar <http://www.camara.sp.gov.br/atividade-legislativa/sessao-plenaria/projetos/>.

$1604^{\text {a }}$ Gestão (2009-2011), Ata da 1 ${ }^{\text {a }}$ Reunião Ordinária do CMH, realizada em 29 de janeiro de 2010.

161 Ibid.

$1624^{\mathrm{a}}$ Gestão (2009-2011), Ata da $6^{\mathrm{a}}$ Reunião Ordinária do CMH, realizada em 24 de fevereiro de 2011.
} 
2013 e 2014 com a abertura e conclusão da eleição dos representantes dos movimentos de moradia.

O ano de 2014 foi um ano atípico para o Conselho, pois sua primeira reunião ordinária ocorreu, somente, em agosto de 2014 e o processo orçamentário para 2015 já se encontrava em curso desde 24 de junho ${ }^{163}$. Por isso, os conselheiros tiveram contato com a proposta orçamentária somente em 27 de novembro de 2014, quando já havia sido formulada e encaminhada à Câmara Municipal de São Paulo ${ }^{164}$. A ausência de participação do CMH no processo de elaboração da proposta orçamentária de 2015 gerou descontentamento entre os conselheiros, como se vê na reclamação a seguir:

Sr. José de Abraão (movimento de moradia) - Não tivemos nenhuma participação na discussão do orçamento [de 2015]. Então, para mim, isso está errado. Se existe um Conselho, esse orçamento tem que ser apresentado para ser encaminhado à Câmara ${ }^{165}$.

O mesmo não ocorreu, por exemplo, no âmbito do Conselho Gestor do Fundo de Desenvolvimento Urbano - FUNDURB, cuja proposta orçamentária e respectivo Plano de Aplicação foram devidamente aprovados por aquele Conselho antes de serem encaminhados à Câmara Municipal ${ }^{166}$.

No caso do CMH, o Plano de Aplicação do FMH para o exercício de 2015 foi apresentado, apenas, em 25 de abril de 2015, já na fase de execução orçamentária ${ }^{167}$.

A situação não se alterou no ano de 2015. O processo de elaboração da proposta orçamentária para 2016 se iniciou em 26/06/2015 ${ }^{168}$, contudo, até a $6^{\text {a }}$ Reunião Ordinária do CMH, realizada em 25 de junho de 2015, não houve a constituição do respectivo Grupo de Planejamento no âmbito do $\mathrm{CMH}$, nem houve apresentação da proposta para discussão e aprovação do Conselho ${ }^{169}$.

Em visita à Secretaria Municipal de Finanças e Desenvolvimento Econômico - SF, em 04 de setembro de 2015, obtivemos a informação de que os Conselhos Municipais de Políticas Públicas do município não costumam participar do referido processo de elaboração

\footnotetext{
163 Para maiores detalhes sobre a atuação dos Grupos de Planejamento (GP) no processo orçamentário do Município de São Paulo, ver "4.5.4 Normas procedimentais".

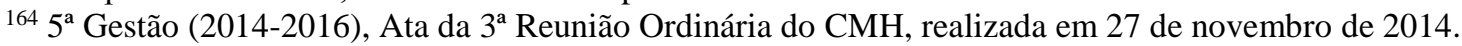

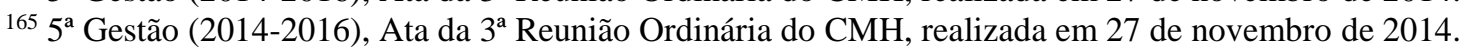

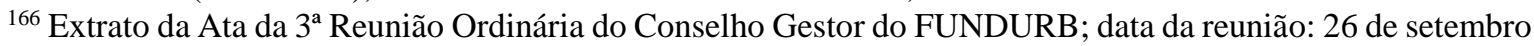
de 2014; publicada no DOCSP em 30 de setembro de 2014, ano 59, n. 182, p. 26; Lei Orçamentária do Município de São Paulo de 2015, aprovada pela Lei Municipal 16.099, de 30 de dezembro de 2014, publicada no DOCSP em 04 de julho de 2015, ano 60, n. 123, p. 34.

$1675^{\text {a }}$ Gestão (2014-2016), Ata da $4^{\circ}$ Reunião Ordinária do CMH, realizada em 22 de janeiro de 2015.

${ }^{168}$ Portaria Intersecretarial 115/15 - SF, loc. cit.

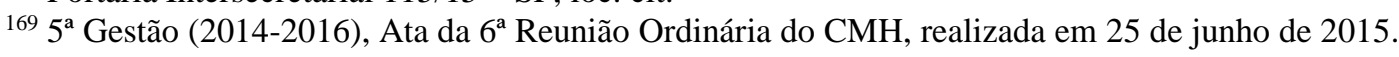


da proposta orçamentária anual ${ }^{170}$.

No decorrer da trajetória do Conselho, notamos ainda que a função de fiscalização e acompanhamento da execução orçamentária pelo Conselho tem se restringido à apreciação das contas do FMH, não havendo indícios evidentes de acompanhamento da implementação das políticas públicas nem avaliação das políticas públicas já executadas.

Como pudemos verificar, o Conselho Municipal de Habitação não participou da elaboração nem aprovou nenhuma das propostas orçamentárias (PPA, LDO e LOA) desde 2003 até 2015; também não participou da elaboração das supracitadas peças orçamentárias da SEHAB relativamente aos recursos destinados à HIS, em flagrante desrespeito ao disposto nos artigos $3^{\circ}$ e $4^{\circ}$ da Lei Municipal 13.425/02 e artigo 168 da Lei Orgânica do Município de São Paulo. Por outro lado, verificamos que a atividade do Conselho tem se concentrado na aprovação de operações na fase de execução orçamentária.

Tais elementos indicam a necessidade do Regimento Interno do $\mathrm{CMH}$ distinguir de maneira mais clara a função deliberativa do Conselho sobre a elaboração da proposta orçamentária (elaboração da política pública) e a função fiscalizatória sobre as operações aprovadas (implementação da política pública).

\subsubsection{Aspectos instrutórios do procedimento administrativo}

Sobre esta categoria, a análise das atas serviu para verificar a frequência e intensidade das reclamações dos conselheiros sobre a falta de informações ou instrução prévia de determinadas solicitações de voto.

Antes de adentrar na análise, convém fazermos uma observação. Considerando que o CMH não participou, como visto, do processo de elaboração das peças orçamentárias, as reuniões tiveram por objeto: a) políticas públicas normativas ou regulatórias. Ex.: Programa de Cortiços, Programa de Mutirões, Programa Bolsa Aluguel etc. e; b) aprovação de operações (projetos ou atividades) a contratar, próprias da fase de execução orçamentária.

Na $8^{a}$ Reunião Ordinária da $1^{\text {a }}$ Gestão (2003-2005), em um caso envolvendo a revisão do "Programa Bolsa Aluguel", a solicitação de voto não foi submetida à votação, pois não dispunha de elementos que a embasassem. Aceita a solicitação de maiores

170 Para maiores detalhes sobre o processo orçamentário municipal de São Paulo, ver "4.5.4 Normas procedimentais". 
informações pela plenária, o voto foi retirado de pauta e a COHAB-SP se incumbiu de providenciar os estudos necessários para instruir a proposta ${ }^{171}$. Este foi um bom exemplo da correta condução do procedimento, abrindo-se a fase instrutória do procedimento administrativo.

Durante a $1^{\mathrm{a}}$ gestão, em face da inexistência de um regimento interno comum aos diversos Grupos de Trabalho - GT, verificamos que os trabalhos dos GTs sofreram descontinuidade entre uma gestão e outra. Além disso, a última reunião desta gestão evidenciou as limitações de um procedimento preponderantemente oral e sem fase instrutória bem definida. A mesma reunião durou cinco horas e versou sobre dezenas de solicitações de voto, envolvendo temas distintos - desde eleições, regularização fundiária, cortiços, habitação para idosos, desapropriação etc. Como resultado, nenhuma solicitação ou encaminhamento foi aprovado $^{172}$. Sobre isso, a literatura indica que a impossibilidade de manifestação e de juntada de documentos antes da reunião ordinária e de vista do processo administrativo para apresentar voto divergente compromete a eficiência (art. 37, CF) do processo decisório e viola os princípios do contraditório e da ampla defesa dos conselheiros (art. 5', LV, CF). Nesse sentido, conferir a doutrina de Medauar (2006; 2014), Ferraz e Dallari (2012) e Gárcia de Enterría e Fernández (2014) ${ }^{173}$.

Conforme ressaltado por Niklas Luhmann (1980), o procedimento exige racionalização interna do método de decisão, o que é possível somente a partir de um elevado grau de especialização do procedimento. Na hipótese, significa que a mesma reunião ordinária não deveria englobar as etapas de instauração, instrução e decisão do procedimento administrativo $^{174}$, sob pena de - como visto - tonar o procedimento ineficiente e moroso.

Nesta $2^{\text {a }}$ Gestão (2005 a 2007), os GTs continuaram a funcionar sem um regimento padrão, ficando a cargo de cada grupo de trabalho definir sua composição, representatividade entre os setores, frequência das reuniões, forma de registro dos trabalhos etc. Por isso, os mesmos problemas observados na gestão anterior foram observados nesta segunda gestão em relação à descontinuidade e inconstância dos trabalhos dos GTs ${ }^{175}$.

Na $2^{\text {a }}$ Reunião Ordinária da $2^{\text {a }}$ Gestão (2005 a 2007) do CMH, a partir da proposta de retomada da reforma de um empreendimento ("São Vito"), inicia-se o debate sobre o desenho institucional dos Grupos de Trabalho - GT, sua composição, representatividade,

${ }^{171} 1^{\text {a }}$ Gestão (2003-2005), Ata da $8^{\text {a }}$ Reunião Ordinária do CMH, realizada em 07 de dezembro de 2004.
${ }^{172} 1^{\text {a }}$ Gestão (2003 a 2005), Ata da $10^{\mathrm{a}}$ Reunião Ordinária do CMH, realizada em 30 de maio de 2005.
${ }^{173}$ Cf. 3.3 .4 Princípios do contraditório e da ampla defesa; 3.5 Etapas do procedimento administrativo.
${ }^{174}$ Cf. 3.5 Etapas do procedimento administrativo.
${ }^{175} 2^{\text {a }}$ Gestão (2005 a 2007), Ata da $2^{\text {a }}$ Reunião Ordinária do CMH, realizada em 22 de fevereiro de 2006. 
periodicidade, direção dos trabalhos etc. Na discussão, ressalta-se a importância da paridade da representação dos diversos setores na composição dos GTs, questão, inclusive, apontada pelo então Secretário Municipal de Habitação, o Sr. Elton Zacarias, e reforçada pelo Sr. Nabil Bonduki, representante do Sindicato dos Arquitetos e Urbanistas do Estado de São Paulo - SASP.

No caso, embora o Poder Executivo (COHAB-SP) já tivesse realizado estudo técnico atestando a inviabilidade econômica e social do empreendimento, o pleno do Conselho decidiu constituir "um grupo para poder discutir, avaliar com mais dados, com mais precisão, a questão do São Vito". Nesse sentido, deliberou-se pela formação de um GT temporário, com representação paritária dos três setores que compõem o $\mathrm{CMH}$, com no mínimo seis e no máximo nove integrantes, tendo o prazo de funcionamento daquela data até a próxima reunião para analisar o estudo feito pela COHAB-SP e apresentar eventuais dados e estudos novos sobre o empreendimento ${ }^{176}$. Este caso demonstra a possibilidade do CMH intervir propositivamente na direção das políticas habitacionais a partir da instrução processual nos Grupos de Trabalho e Comissões Temáticas.

Apresentamos, a seguir, um caso de suspensão da etapa decisória e retorno à etapa instrutória, por falta de elementos que embasassem uma solicitação de voto, confira-se ${ }^{177}$ :

Sr. Abelardo Diaz (sociedade civil) - Parece, do ponto de vista da apresentação da proposta, que está um pouco simplista [...]. Acha que precisam estar melhor explicitadas na resolução, e que seria interessante, também, trazer informações do público que está sendo atingido e do impacto econômico disso (destaque nosso).

A Sra. Maria Lúcia Martins (sociedade civil) - fica bastante difícil ser um voto aprovado em cima de uma coisa que não se conhece exatamente o que é. [...] acha que para um efetivo voto faltaria ter elementos um pouco mais precisos (destaque nosso).

Sra. Lisete Rubano (sociedade civil) - reitera a necessidade de ter mais informações, porque vai ser uma política na verdade de comercialização e precisa ser bem construída, reitera esse tempo a mais necessário para que se reflita e essa proposta seja melhor detalhada (destaque nosso).

Embora a solicitação tenha sido retirada de pauta, não foi encaminhada para algum Grupo de Trabalho, competindo ao próprio proponente reapresentar a solicitação de voto suprindo as deficiências apontadas pelos conselheiros. A pouca importância conferida aos GTs pode ser explicada pela inexistência de Regimento Interno dos Grupos de Trabalho naquela época (2005 a 2007), o qual foi aprovado somente na $4^{\mathrm{a}}$ Gestão (2009 a 2011).

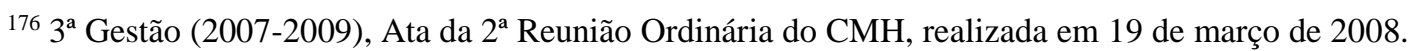

$1772^{\text {a }}$ Gestão (2005 a 2007), Ata da 4a Reunião Ordinária da CECMH, realizada em 8 de novembro de 2006. 
$\mathrm{Na} 3^{\mathrm{a}}$ Reunião Ordinária da $3^{\mathrm{a}}$ Gestão (2007-2009) do $\mathrm{CMH}$, diante de uma solicitação de voto do poder público para autorização de repasse do Edifício São Vito à Empresa Municipal de Urbanização de São Paulo - EMURB com respectivo reembolso ao FMH, o Sr. Luiz Kohara solicitou informações não repassadas aos conselheiros. Ignorando a solicitação, o voto foi colocado em votação e aprovado pela maioria dos votos ${ }^{178}$.

Em sua declaração de voto, o Sr. Kohara alertou "para a necessidade de se promover as discussões primeiramente nos GTs, para que haja de fato aprofundamento das reflexões e só posteriormente trazer as solicitações de voto para deliberação no Conselho" ${ }^{179}$. Esta manifestação indica que as solicitações de voto eram frequentemente encaminhadas à votação sem a precedente instrução processual ou participação dos demais conselheiros.

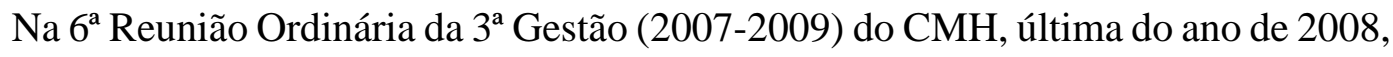
a Sra. Violeta Kubrusly, representante do poder público, propôs "o fortalecimento dos grupos de trabalho e que deles realmente venham as pautas mais importante para o conselho. É neles que você faz análise dos temas mais candentes de conjunturas". Apesar da solicitação de maior atenção aos GTs, não houve encaminhamento daquela proposta até o encerramento das atividades daquela gestão. ${ }^{180}$

Evidenciando deficiências instrutórias no processo decisório do Conselho, os conselheiros da sociedade civil e dos movimentos de moradia fizeram os seguintes apelos na $4^{\text {a }}$ Gestão (2009-2011) do CMH:

Sr. Luiz Kohara (sociedade civil) - [...] até porque a democracia é qualificar a forma de participação, não simplesmente levantarmos o braço ou não, acho que tinha que dizer exatamente o que o Maksuel pediu [...] a forma de encaminhar tem que ser precisa, também a forma de apresentar, é importante que, um texto público, para ser votado, tem quer ser mais preciso, e mais explicitado (destaque nosso) ${ }^{181}$.

Sr. Maksuel Costa (movimento popular) - Eu coloco como proposta para que na próxima reunião, como o senhor mesmo disse, apresentem esse plano sim, esse plano estratégico de atuação da $\mathrm{COHAB}$, a importância de estarmos atuando dentro do que a COHAB ou a Secretaria de Habitação tem como plano estratégico, automaticamente não conhecendo o plano, o que a Secretaria está pensando, o que a COHAB está pensando, parece, como o Dito colocou, que só estamos levantando a mão para votar coisas que desconhecemos $\left(\right.$ destaque nosso) ${ }^{182}$.

Sr. Luiz Maldonado (movimento popular) - o que eu pediria aos senhores é o seguinte, que suspendessem hoje essa votação, solicitação de voto (destaque nosso) ${ }^{183}$.

$1783^{\text {a }}$ Gestão (2007-2009), Ata da 3 ${ }^{\text {a }}$ Reunião Ordinária do CMH, 17 de junho de 2008.

179 Ibid.

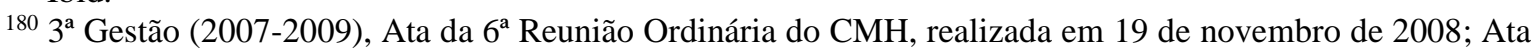

da $10^{\text {a }}$ Reunião Ordinária do CMH, realizada em 16 de setembro de 2009.

$1814^{\text {a }}$ Gestão (2009-2011), Ata da $1^{\text {a }}$ Reunião Ordinária do CMH, Ibid.

182 Ibid.

183 Ibid. 
Embora alguns conselheiros tivessem requerido a suspensão da votação e o suprimento de informações necessárias para o conhecimento da solicitação de voto, a mesa diretora, sob a presidência do Secretário de Habitação, Sr. Elton Santa Fé Zacarias, procedeu à votação imediata da solicitação de voto.

Neste caso, aos conselheiros com posicionamento divergente deveria ter sido assegurado o direito de vista dos autos da solicitação de voto em nome das garantias processuais da ampla defesa e do contraditório (FERRAZ; DALLARI, 2012; GÁRCIA DE ENTERRIA; FERNÁNDEZ, 2014).

No contexto desse debate, a Sra. Elisabete, representante do poder público, sugeriu a criação de um grupo de trabalho para debater as funções e desenho institucional do Conselho e, principalmente, possíveis alterações nas normas que regem o funcionamento do Conselho e de seus GTs ${ }^{184}$. Como decorrência desse debate, em 13 de abril de 2010, o CMH editou o Regimento Interno dos Grupos de Trabalho ${ }^{185}$, até então inexistente.

$\mathrm{Na}$ mesma reunião, os conselheiros ressaltaram a ausência do relatório final das atividades de diversos Grupos de Trabalho - GTs da gestão anterior ${ }^{186}$, o que indicou a ausência de arquivos e registros (autuação de processos administrativos) dos trabalhos dos GTs. Além disso, em visita à Secretaria Executiva do CMH em março de 2015, recebemos à informação de que as solicitações de voto não costumam ser autuadas em processos administrativos, apesar de haver planos de implementar essa prática. Não temos informações se esta medida já se efetivou.

Deve-se ressaltar que a ausência de registros das atividades dos GTs compromete a continuidade do trabalho entre uma gestão e outra, bem como dificulta o acesso desses resultados pelos demais conselheiros e, por que não dizer, pela sociedade em geral.

Aliás, a autuação de documentos é pressuposto do próprio processo administrativo, cujo princípio do devido processo legal ou do formalismo moderado não dispensa a prática de atos processuais escritos e mesmo as intervenções orais durante as reuniões são transcritas em atas nos termos do Regimento Interno do CMH. Não se trata de burocratizar o processo decisório, mas, ao contrário, conferir-lhe condições de se desenvolver de maneira célere e eficiente, conforme indicam Odete Medauar (2014) e Gárcia de Enterría e Fernández

\footnotetext{
$1844^{\text {a }}$ Gestão (2009-2011), Ata da $1^{\text {a }}$ Reunião Ordinária do CMH, realizada em 29 de janeiro de 2010.

185 Regimento Interno dos Grupos de Trabalho do CMH.

$1864^{\text {a }}$ Gestão (2009-2011), Ata da $1^{\text {a }}$ Reunião Ordinária do CMH, Ibid.
} 
$(2014)^{187}$

Na 2 $2^{\text {a }}$ Reunião Ordinária da $4^{\text {a }}$ Gestão (2009-2011), um representante do poder público apresentou uma solicitação de voto envolvendo 860 mil reais para retomar a execução de um empreendimento contratado em 2007, mas cujas obras estavam paralisadas. Diversas dúvidas foram levantadas e não puderam ser respondidas na reunião, conforme expôs o conselheiro Abelardo Diaz, representante da sociedade civil: "o voto foi colocado com rapidez, essas coisas a gente tem que olhar com calma". Não obstante, a mesa diretora, presidida pelo Secretário Municipal da SEHAB, colocou a matéria em votação, aprovandoa por maioria de votos. ${ }^{188}$

$\mathrm{Na} \quad 3^{\mathrm{a}}$ Reunião Ordinária da $4^{\mathrm{a}}$ Gestão (2009-2011), ocorreram novos questionamentos quanto ao processo decisório do $\mathrm{CMH}$, especialmente quanto à falta de informações e instrução processual. Em uma solicitação de voto no valor de 30 milhões de reais, equivalente a $60 \%$ (sessenta por cento) dos recursos do FMH para aquele exercício, o conselheiro Kazuo Nakano, representante da sociedade civil, solicitou que o voto fosse retrabalhado, aprofundado, complementando certas lacunas ${ }^{189}$.

Em complemento, o conselheiro Benedito Barbosa, representante dos movimentos de moradia, ressaltou que "as Resoluções, elas são complexas e de debate, eu acho que fazer uma reunião das duas às cinco horas, as últimas Resoluções não são debatidas e não conseguimos fazer a discussão, a minha proposta inclusive era de fazer as reuniões o dia todo" 190 . O Sr. Sidney, ouvinte e militante dos movimentos sociais, lembrou que não é possível aprofundar ou instruir as Resoluções nas reuniões ordinárias, "mas quando se remete lá no GT do Conselho, acabamos construindo e ampliando mais essa discussão" 191 . No entanto, mais uma vez, as solicitações de informações foram desconsideradas e o voto foi aprovado tal como estava ${ }^{192}$.

Ainda sobre o caso, o conselheiro Pedro Arantes ressaltou que a falta de transparência sobre os elementos materiais que fundamentaram a solicitação de voto e a inexistência de discussão prévia com os conselheiros abrem a possibilidade de cooptação do CMH por interesses privados e patrimonialistas ${ }^{193}$.

\footnotetext{
${ }^{187}$ Cf. tópicos 3.3.1 Princípio do devido processo legal ou do formalismo moderado. Ver ainda 3.4 Etapas do procedimento administrativo nos Conselhos. 3.4.1 Instauração.

$1884^{\text {a }}$ Gestão (2009-2011), Ata da 2 ${ }^{\mathrm{a}}$ Reunião Ordinária do CMH, realizada em 18 de março de 2010.

$1894^{\text {a }}$ Gestão (2009-2011), Ata da 3 $3^{\text {a }}$ Reunião Ordinária do CMH, realizada em 20 de maio de 2010.

190 Ibid.

191 Ibid.

192 Ibid.

$1934^{\text {a }}$ Gestão (2009-2011), Ata da $3^{\text {a }}$ Reunião Ordinária do CMH, realizada em 20 de maio de 2010.
} 
Na 1a Reunião Extraordinária da $4^{\text {a }}$ Gestão (2009-2011) do CMH, o conselheiro Abelardo Diaz, representante da sociedade civil, apresentou a seguinte sugestão:

Sr. Abelardo Diaz (sociedade civil) - Eu queria reiterar um apelo que eu tive oportunidade de fazer na última reunião do Conselho eu (sic) fui surpreendido aqui com o voto número 12 de 37 milhões, sem nenhuma prévia discussão, não me parece apropriado num fórum grande como o nosso, com o tempo curto como o nosso, ser surpreendido em uma reunião com votos importantes, sem que eles tenham sido previamente discutidos, aprofundados, melhor trabalhados, eu tenho assistido aqui às vezes discussões intermináveis de assuntos que não está bem entendido, que poderia ter sido pacificado, eu queria aqui reiterar um apelo que já fiz para que os votos fossem previamente encaminhados para a Executiva ou para um grupo de apoio (destaque nosso) ${ }^{194}$.

Conforme exposto acima, ao invés de serem colocados em votação na primeira reunião ordinária, as solicitações de voto deveriam seguir as etapas de instauração e de instrução processual prévias.

Durante a $1^{\text {a }}$ Reunião Extraordinária da $4^{\text {a }}$ Gestão (2009-2011), uma solicitação de voto pretendia instituir a política municipal de prevenção e mediação de conflitos fundiários e urbanos, proposta pelos movimentos populares. As objeções apresentadas versaram sobre ausência de discussão prévia em Grupo de Trabalho e inviabilidades de ordem técnica e jurídica. Por conta disso, após intenso debate, a solicitação de voto foi retirada de pauta pelos proponentes $^{195}$.

$\mathrm{Na} 5^{\mathrm{a}}$ Reunião Ordinária da $4^{\mathrm{a}}$ gestão (2009-2011) do $\mathrm{CMH}$, o poder público municipal apresentou solicitação de voto para implantação de infraestrutura em projeto já executado do Minha Casa Minha Vida - PMCMV, ou seja, o programa não havia contado com recursos do FMH em seu planejamento inicial. Por isso, o conselheiro Pedro Arantes questionou o uso de recursos do Fundo para essa finalidade e sem retorno, a fundo perdido. No entanto, apesar de todos esses questionamentos e da ausência de participação dos demais conselheiros na construção dessa política pública, o voto foi aprovado por maioria de votos, com duas abstenções e sem alteração de texto ${ }^{196}$.

As solicitações de informações e de produção de provas relatadas acima são evidências de que o procedimento administrativo adotado pelo Conselho entre 2003 e 2015 não vem seguindo adequadamente as etapas de instauração, instrução e decisão inerentes a todo processo administrativo (GÁRCIA DE ENTERRIA; FERNÁNDEZ, 2014; MEDAUAR, 2008; FERRAZ; DALLARI, 2012). Em síntese: a) o regimento interno não

\footnotetext{
$1944^{\text {a }}$ Gestão (2009-2011), Ata da 1a Reunião Extraordinária do CMH, realizada em 24 de junho de 2010. 195 Ibid.

$1964^{\mathrm{a}}$ Gestão (2009-2011), Ata da 5 $5^{\mathrm{a}}$ Reunião Ordinária do CMH, realizada em 18 de novembro de 2010.
} 
prevê a manifestação por escrito e a juntada documentos sobre a solicitação de voto antes da reunião ordinária; b) não há previsão regulamentar para a vista dos autos do processo administrativo antes da votação; c) em diversos momentos, mesmo diante de falta de informações e havendo dúvidas sobre o conteúdo das solicitações de voto, procedeu-se à imediata votação suprimindo a etapa instrutória.

Por fim, em relação aos mecanismos de prestação de contas à sociedade em geral, encontramos sugestão de realização de audiência pública para discussão do Plano Municipal de Habitação em $2003^{197}$, porém não consta notícias se o evento de fato ocorreu. A $2^{\mathrm{a}}$ Conferência Municipal de Habitação foi objeto de pauta em diversos momentos $\left(2004^{198}\right.$, $2007^{199}, 2010^{200}, 2015^{201}$ ), contudo, ainda não foi realizada. Por fim, não encontramos registro de audiências de prestação de contas semestrais ou anuais realizada pelo Conselho no período pesquisado. Sobre esta questão, já tivemos a oportunidade de discutir a importância desse tipo de mecanismo para a manutenção e fortalecimento da legitimidade da representação política dos conselheiros (TATAGIBA, 2010; TEIXEIRA, 2005; AUAD, 2007; OLIVEIRA, 2010). Em vista disso, recomendamos a previsão de meios de prestação de contas periódicos (audiências públicas, boletins informativos entre outros) no Regimento Interno do $\mathrm{CMH}$.

$1971^{\text {a }}$ Gestão (2003-2005), Ata da $1^{\text {a }}$ Reunião Extraordinária do CMH, realizada em 24 de setembro de 2003.

$1981^{\text {a }}$ Gestão (2003-2005), Ata da $4^{\text {a }}$ Reunião Ordinária do CMH, realizada em 29 de março de 2004.

$1993^{\text {a }}$ Gestão (2007-2009), Ata da $6^{\text {a }}$ Reunião Ordinária do CMH, realizada em 19 de março de 2007.

$2004^{\text {a }}$ Gestão (2009-2011), Ata da $1^{\text {a }}$ Reunião Ordinária da CECMH, realizada em 23 de fevereiro de 2010.

$2015^{\mathrm{a}}$ Gestão (2014-2016), Ata da $4^{\mathrm{a}}$ Reunião Ordinária da CECMH, realizada em 24 de março de 2015. 


\section{CONCLUSÃO}

Ao estudarmos os Conselhos Municipais de Políticas Públicas, constatamos duas grandes problemáticas. A primeira relacionou-se à baixa capacidade de proposição de políticas públicas ou de redefinição política dos gastos públicos (TATAGIBA, 2010). Como possível causa, apuramos que as atividades de planejamento e de orçamento ainda são vividas pelos Conselhos como "mundos distintos", daí sua pouca influência na elaboração das peças orçamentárias e, consequentemente, sua pouca ingerência na definição de programas de ação, diretrizes, metas, objetivos e alocação de recursos em políticas públicas (OLIVEIRA, 2014). A segunda problemática refere-se à frequente deliberação sem a precedente realização de instrução processual e sem o exercício do contraditório pelos demais conselheiros (CARNEIRO, 2006).

Tais problemáticas nos conduziram, respectivamente, aos referenciais teóricos do processo orçamentário e do processo administrativo.

Com base neles, elegemos como objetivos gerais da pesquisa: a) a análise do regime jurídico dos procedimentos administrativos aplicáveis aos Conselhos; b) a participação dos Conselhos no processo orçamentário municipal de São Paulo. Como objetivos específicos de pesquisa, decidimos verificar empiricamente: a) a adequação dos procedimentos administrativos que regem o CMH de 2003 a 2015; b) a participação do CMH no processo orçamentário municipal de São Paulo de 2003 a 2015, à luz do referencial teórico em destaque.

Algumas questões guiaram o desenvolvimento desta pesquisa, tais como: que regras procedimentais deveriam ser observadas no âmbito dos Conselhos em geral? De que maneira os Conselhos deveriam participar do processo orçamentário municipal de São Paulo? Os conselheiros têm exercido adequadamente os direitos ao contraditório e à ampla defesa nos procedimentos administrativos do $\mathrm{CMH}$ ? Em caso de participação procedimental deficiente, quais seriam as possíveis causas? Como tem se desenvolvido a participação do CMH no processo orçamentário municipal de São Paulo? Em caso de participação inexistente ou deficiente, quais seriam as possíveis causas?

A partir do referencial teórico, orientado pelos objetivos gerais da pesquisa, chegamos aos resultados abaixo.

A participação de uma porção de representantes da sociedade civil nos Conselhos não afasta o direito de participação de outros interessados (pessoas, grupos ou entidades e 
organizações de defesa de interesses difusos ou coletivos) em seu processo decisório, segundo os pressupostos teóricos e legais da: (a) procedimentalização da atividade administrativa $^{202}$, (b) do princípio da ampla defesa e do contraditório ${ }^{203}$ e (c) das etapas de instauração e instrução processual envolvendo interesses difusos ${ }^{204}$.

Outro ponto de destaque diz respeito à obrigatória oportunidade de manifestação prévia sobre as solicitações de voto (proposições ou pauta de reunião) e juntada de documentos pelos demais conselheiros, antes da sessão deliberativa, a fim de lhes garantir o exercício do contraditório. Além disso, revela-se de suma importância a previsão de procedimentos de instrução probatória nos Conselhos, sobretudo, voltados à realização de conferências de serviço, consultas públicas ou audiências públicas ${ }^{205}$. Em nosso entendimento, tais orientações ampliam e aprimoram o conhecimento a respeito das regras procedimentais até então citadas pela doutrina em relação aos Conselhos em geral.

A composição plural dos Conselhos confere-lhes a condição de órgão público privilegiado no ciclo de formação da política pública. Os instrumentos legais de planejamento e orçamento previstos no artigo 165 da Constituição Federal, o PPA, a LDO e a LOA podem ser considerados expressões jurídicas das políticas públicas. Os Conselhos devem participar obrigatoriamente do processo orçamentário municipal (PDE, PPA, LDO, LOA) de São Paulo, segundo o disposto nos artigos $8^{\circ}$ e $9^{\circ}$ da LOMSP. Os procedimentos administrativos internos dos Conselhos devem observar os requisitos materiais e os prazos orçamentários previstos na LOMSP. A ausência de participação dos Conselhos deliberativos, na condição de órgão setorial, no processo orçamentário anual (LDO e LOA) ou quadrianual (PPA) instituídos pela Secretaria Municipal de Finanças e Desenvolvimento Econômico (SF), vicia a proposta orçamentária na parte relativa aos Conselhos, pois viola a atribuição legal dos Conselhos definirem os programas de ação, as diretrizes, as metas e os objetivos relacionados às políticas públicas setoriais de sua competência. Em nosso entendimento, tais orientações ampliam e aprimoram o conhecimento a respeito das regras de processo orçamentário até então citadas pela doutrina em relação aos Conselhos Municipais de Políticas Públicas de São Paulo.

A partir do referencial teórico, orientado pelos objetivos específicos da pesquisa, o estudo de caso longitudinal do CMH de 2003 a 2015 apresentou os seguintes resultados:

\footnotetext{
${ }^{202}$ Cf. 3.1 Procedimentalização da atividade administrativa.

${ }^{203}$ Cf. 3.3.4 Princípio do contraditório e da ampla defesa.

${ }^{204}$ Cf. 3.4.1 Instauração e 3.4.2 Instrução.

205 Loc. cit.
} 
As proposições de voto não têm sido autuadas no processo administrativo do $\mathrm{CMH}$, o que pode estar relacionado à ausência de previsão legal para a autuação dos atos processuais na Lei Municipal 13.425/02 ou no Regimento Interno do Conselho (2003). A simples falta de formação dos autos do processo administrativo pode explicar a descontinuidade dos trabalhos dos Grupos de Trabalho relatada em momentos diferentes do Conselho, com a perda de informações entre as gestões, e outras deficiências expostas a seguir.

A solicitação de voto é colocada em votação - etapa decisória - já na primeira reunião ordinária, sem a realização adequada da fase de instauração e instrução processual, principalmente, quanto ao direito de manifestação e juntada de documentos previamente à reunião ordinária, ao direito de vista dos autos e quanto à possibilidade de solicitação de provas ou encaminhamento prévio da solicitação de voto aos Grupos de Trabalho. Esses elementos evidenciam a necessidade de revisão da Lei Municipal 13.425/02 e do Regimento Interno do Conselho, para que os procedimentos administrativos do $\mathrm{CMH}$, no mínimo, adequem-se ao regime jurídico geral apresentado no capítulo 3.

Houve resultados positivos na definição de políticas públicas habitacionais regulamentares, por exemplo: Programa de Cortiços; Programa de Mutirões; Bolsa Aluguel; Plano Municipal de Habitação, Parceria Social; critérios de seleção de beneficiários ao Programa Minha Casa Minha Vida etc.

A atuação do CMH tem se mostrado deficitária na elaboração de políticas públicas concretas (ex.: construção de unidades habitacionais, urbanização de favelas e regularização fundiária), pois o Conselho não participou, na condição de órgão setorial deliberativo, da elaboração de nenhuma proposta orçamentária da SEHAB ou da elaboração e aprovação da proposta orçamentária do FMH e de seu plano de metas. Este fato, certamente, prejudica a gestão democrática da política pública habitacional e esvazia as funções institucionais do CMH previstas na Lei Municipal 13.425/02, já que a definição dos programas de ação, das diretrizes, das metas, dos objetivos e do plano de aplicação de recursos do FMH para HIS ficam a cargo da SEHAB ao invés do CMH.

Por outro lado, observamos que o $\mathrm{CMH}$ tem exercido atribuições, tipicamente, de gestão do FMH ao aprovar as operações (projetos e atividades) a executar. Embora possua competência legal e técnica para fiscalizar se a política pública executada pela COHAB-SP está de acordo com as diretrizes previstas na lei orçamentária e demais resoluções do $\mathrm{CMH}$, entendemos que o Conselho não tem capacidade legal nem técnica para apreciar e julgar aspectos operacionais próprios da fase de implementação da política pública. Ainda que 
digam respeito à fase de execução da política pública, trata-se de funções inconfundíveis: fiscalização e avaliação versus implementação da política pública.

Aliás, entendemos que os problemas instrutórios relatados acima podem estar relacionados, em grande parte, com o exercício de atribuições estranhas às competências legais e administrativas do Conselho. Ao invés de dedicar-se a analisar e aprovar a implementação das operações a contratar, seria mais adequado que o $\mathrm{CMH}$ se concentrasse nas funções institucionais de elaboração das políticas públicas e da proposta orçamentária do FMH; bem como na função de fiscalização e avaliação das políticas públicas no que diz respeito aos programas, diretrizes, objetivos, metas e plano de aplicação de recursos previstos na LOA.

No que concerne à função de fiscalização e acompanhamento da execução orçamentária, o Conselho tem se restringido a apreciar e aprovar as contas do FMH, não havendo indícios evidentes de acompanhamento da implementação nem de avaliação das políticas públicas já executadas. Fatos esses que, naturalmente, comprometem a qualidade das políticas públicas elaboradas pelo $\mathrm{CMH}$ em vista da inexistência de um ciclo de formação da política pública, propriamente dito ${ }^{206}$.

Por fim, a respeito de mecanismos de prestação de contas à sociedade em geral, verificamos que não há previsão normativa na Lei Municipal 13.425/02 nem no Regimento Interno do $\mathrm{CMH}$, bem como não encontramos registros da realização de audiências públicas para esse fim nas atas de reunião no período pesquisado.

Esses elementos evidenciam a necessidade de revisão e aprimoramento dos Regimentos Internos do Conselho, da Comissão Executiva e dos Grupos de Trabalho, adequando-os aos princípios do processo administrativo, notadamente, do contraditório e da ampla defesa dos conselheiros, bem como para especificar de maneira mais clara a função deliberativa do Conselho para a fase de elaboração da proposta orçamentária (elaboração da política pública) e a função fiscalizatória para a fase de execução orçamentária (implementação da política pública).

Como sugestão de pesquisa, somos favoráveis à replicação dos referenciais teóricos do processo administrativo e do processo orçamentário municipal em outros Conselhos Municipais de Políticas Públicas, haja vista os potenciais benefícios práticos da pesquisa para o melhor funcionamento desses Conselhos e para a adequada articulação administrativa entre os órgãos envolvidos no ciclo de formação das políticas públicas.

${ }^{206}$ A respeito, vide 4.1 Ciclo de formação das políticas públicas (policy cicle). 


\section{REFERÊNCIAS BIBLIOGRÁFICAS}

AFONSO DA SILVA, José. Curso de Direito Constitucional Positivo. $37^{\mathrm{a}}$ ed. São Paulo: Malheiros Editores, 2014.

AGGIO, Alberto. Regime militar e transição democrática: um balanço do caso brasileiro. Estudos de Sociologia. v. 1, n. 1, p. 55-64, 1996.

ALMEIDA, Carla; CAYRES, Domitila Costa; TATAGIBA, Luciana Tatagiba. Balanço dos estudos sobre os conselhos de políticas públicas na última década. Lua Nova, São Paulo, n. 94, abril, p. 255-294, 2015.

AMANDO DE BARROS, Laura Mendes. O fomento e o Conselho de Direitos da Criança e do Adolescente de São Paulo. Dissertação de Mestrado. Faculdade de Direito da Universidade de São Paulo, São Paulo, 2012.

ARENDT, Hannah. A Condição Humana. São Paulo: Forense-Universitária Salamandra Consultoria Editorial Edusp, 1981.

ASSONI FILHO, Sérgio. Transparência fiscal e democracia. Porto Alegre: Núria Fabris Editora, 2009.

AUAD, Denise. Conselhos e Fundos dos Direitos da Criança e do Adolescente: uma opção pela democracia participativa. Tese de Doutorado. Faculdade de Direito. Universidade de São Paulo, São Paulo, 2007.

AVRITZER, Leonardo. Democratization and Changes in the Pattern of Association in Brazil. Journal of Interamerican Studies and World Affairs. vol. 42, n. 3, Outono, 2000.

Modelos de Deliberação Democrática: uma análise do orçamento participativo no Brasil. In: SANTOS, Boaventura de Souza. Democratizar a democracia: os caminhos da democracia participativa. Rio de Janeiro: Civilização Brasileira, 2002a.

O Orçamento Participativo: As experiências de Porto Alegre e Belo Horizonte. In: DAGNINO, Evelina (Org.) Sociedade Civil e Espaços Públicos no Brasil. São Paulo: Paz e Terra, 2002b.

. Sociedade Civil, Instituições Participativas e Representação: Da Autorização à Legitimidade da Ação. DADOS - Revista de Ciências Sociais, Rio de Janeiro, v. 50, n. 3, 2007, pp. 443-464.

AVRITZER; Leonardo; WAMPLER, Brian. Públicos participativos: sociedade civil e novas instituições no Brasil democrático. In: COELHO, Vera Schattan P; NOBRE, Marcos (org.) Participação e deliberação: teoria democrática e experiências institucionais no Brasil contemporâneo. São Paulo, Ed. 34, 2004.

BACHUR, João Paulo. Conflito, procedimento e os novos movimentos sociais - uma 
perspectiva a partir da teoria dos sistemas de Niklas Luhmann. Artigo apresentado no $6^{\circ}$ Encontro da Associação Brasileira de Ciência Política (ABCP), 2008.

BANDEIRA DE MELLO, Celso Antônio. Curso de direito administrativo. $31^{\text {a }}$ ed. São Paulo: Malheiros Editores, 2014.

BARDIN, Laurence. Análise de Conteúdo. Tradução de Luís Antero Reto e Augusto Pinheiro. $5^{\text {a }}$ ed. Lisboa: Edições 70, 2009.

BARNES, Javier. Toward a third generation of administrative procedure. In: ACKERMAN, Susan Rose e LINDSETH, Peter. Comparative Administrative Law, Edward Elgar, United Kingdon, 2012.

BOBBIO, Norberto. O futuro da democracia: uma defesa das regras do jogo. Rio de Janeiro: Paz e Terra, 1986.

BOBBIO, Norberto; MATTEUCCI, Nicola; PASQUINO, Gianfranco. Dicionário de Política. trad. Carmen C, Varriale et. all., Brasília: Editora Universidade de Brasília, 11 a ed., 1998.

BORBA, Julian; LÜCHMANN, Lígia Helena Hahn. A representação política nos Conselhos Gestores de Políticas Públicas. Revista Brasileira de Gestão, v. 2, n. 2, p. 229-246, jul./dez. 2010.

BOSCHI, Renato Raul. A arte da associação: política de base e democracia no Brasil; trad. Maria Alice da Silva Ramos. São Paulo: Vértice, Editora Revista dos Tribunais; Rio de Janeiro: Instituto Universitário de Pesquisas do Rio de Janeiro, 1987.

BRASIL. Ministério da Saúde. Manual de orçamento e finanças públicas para conselheiros de saúde. Conselho Nacional de Saúde, 2011. Disponível em: <http://conselho.saude.gov.br/biblioteca/livros/ManualdeOrcamento.pdf >. Acesso em: 30/01/2015.

Ministério do Planejamento, Orçamento e Gestão. Secretaria de Orçamento Federal. Manual técnico de orçamento MTO. Edição 2015. Brasília, 2014.

. Superior Tribunal de Justiça. Recurso Especial no 493.811/SP, Rel. Ministra Eliana Calmon, Segunda Turma, julgado em 11/11/2003, DJ 15/03/2004, p. 236.

. Supremo Tribunal Federal. Ação Direta de Inconstitucionalidade-Medida

Cautelar no 1726/DF, Tribunal Pleno, Rel. Min. Maurício Corrêa, j. 16.09.1998

BRELÀZ, Gabriela de. O Processo de Institucionalização da Participação na Câmara Municipal de São Paulo - uma Análise das Audiências Públicas do Orçamento (19902010). Tese (Doutorado). Escola de Administração de Empresas de São Paulo. Fundação Getúlio Vargas, São Paulo, 2012.

BRESSER PEREIRA, Luiz Carlos. Da Administração Pública Burocrática à Gerencial. Revista do Serviço Público, 47(1) janeiro1996. 
BUCCI, Maria Paula Dallari. Direito administrativo e políticas públicas. $1^{\text {a }}$ ed., São Paulo: Saraiva, 2006a.

. O conceito de política pública em direito. In Políticas Públicas: reflexões sobre o conceito jurídico. Maria Paula Dallari Bucci (organizadora). São Paulo: Saraiva, 2006b.

Fundamentos para uma teoria jurídica das políticas públicas. $1^{\mathrm{a}}$ ed. $2^{\mathrm{a}}$ t., São Paulo: Editora Saraiva, 2013.

CAETANO, Marcelo. Tendências do direito administrativo europeu. Revista de Direito Público, v. 1, n. 1, p. 25-39, jul./set. 1967.

CÂMARA, Jacintho Arruda. Plano Diretor. In: DALLARI, Adilson Abreu; FERRAZ, Sérgio (coord.) Estatuto da Cidade: comentários à Lei Federal 10.257/2001. São Paulo: Malheiros Editores, p. 304-321, 2002.

CANOTILHO, Joaquim José Gomes. Direito constitucional. $6^{a}$ ed. Coimbra: Almedina, 1993.

CAPPELA, Ana Cláudia Niedhardt; BRASIL, Felipe Gonçalves. Subsistemas, comunidades e redes para a análise da participação no processo de políticas públicas. Revista Brasileira de Políticas Públicas. v. 4. n. 2, jul./dez, 2014.

CARNEIRO, Carla Bronzo Ladeira. Conselhos de políticas públicas: desafios para sua institucionalização. In: SARAIVA, Enrique; FERRAREZI, Elisabete (orgs.). Políticas públicas: coletânea. Brasília: ENAP, p. 149-166, 2006.

CARVALHO FILHO, José dos Santos. Propriedade, Política Urbana e Constituição. In: SOUSA, Horárcio Augusto Mendes de; FRAGA, Henrique Rocha (coord.). Direito Municipal Contemporâneo: novas tendências. Belo Horizonte: Fórum, p. 209-230, 2010.

CASSESE, Sabino. New Paths of Administrative Law - a manifesto. Internacional Journal of Constitutional Law, vol. 10 n. 3, 2012.

A crise do Estado. Saberes, 2010.

CHEVALLIER, Jaques. O estado pós-moderno. Trad. Marçal Justen Filho. Belo Horizonte: Editora Fórum: 2009.

COMPARATO, Fábio Konder. Ensaio sobre o juízo de constitucionalidade de políticas públicas. In: Revista de Informação legislativa. Brasília a. 35 n. 138 abr./jun. 1998.

Planejar o desenvolvimento: perspectiva institucional. Revista Trimestral de Direito Público. São Paulo, v. 21, n. 88, p. 18-43, out/dez. 1998.

CONTI, José Maurício. Da elaboração da proposta orçamentária. In: CONTI, José Maurício Conti (coord.). Orçamentos públicos - a Lei 4.320/1964 comentada. São Paulo: Editora Revista dos Tribunais, 2008. 
CRUZ, Maria do Carmo Meirelles. Desafios para o funcionamento dos Conselhos. In: CARVALHO, M.C.A.A; TEIXEIRA, A.C.C (Orgs.). Conselhos gestores de políticas públicas. São Paulo, Pólis, 2000, p. 73-77.

CYMBALISTA, Renato; SANTORO, Paula Freire; TATAGIBA, Luciana; TEIXEIRA, Ana Cláudia Chaves. Habitação: controle social e política pública. Série Observatório dos direitos do cidadão. Acompanhamento e análise das políticas públicas da cidade de São Paulo São Paulo: Instituto Pólis, 2007.

DAGNINO, Evelina et. all. Cultura democrática e cidadania. Opinião pública, v. V, n. 1, nov. p. 20-71, 1998.

Sociedade Civil, Espaços Públicos e a Construção democrática no Brasil: Limites e Possibilidades. In: DAGNINO, Evelina (Org.). Sociedade Civil e Espaços Públicos no Brasil. São Paulo: Paz e Terra, 2002.

DAHL, Robert. Poliarquia. Tradução: Fernando Limongi. São Paulo: EDUSP, 1997.

DI PIETRO, Maria Sylvia Zanella. Direito administrativo. 27ª ed., São Paulo: Atlas, 2014. Participação Popular na Administração Pública. Revista Trimestral de Direito Público, n. 1, p. 127-139, 1993.

DIAS, Solange Gonçalves. Democracia representativa x democracia participativa: Participação popular no local e emergência de um novo paradigma democrático. Dissertação de Mestrado. Faculdade de Direito da Universidade de São Paulo, São Paulo, 2001.

DINIZ, Maria Helena. Dicionário jurídico. v. 4, São Paulo: Saraiva, 1998.

DONAGHY, Maureen M. Do Participatory Governance Institutions Matter? Municipal Councils and Social Housing Programs in Brazil. Comparative Politics, Vol. 44, No. 1 oct., pp. 83-102, 2011.

DRUMOND, Alexandre Matos; SILVEIRA, Suely de Fátima Ramos; SILVA, Edson Arlindo. Predominância ou coexistência? Modelos de administração pública brasileira na Política Nacional de Habitação. Revisa de Administração Pública. Rio de Janeiro, v. 48, n. 1, jan./fev., p. 3-25, 2014.

DUARTE, David. Procedimentalização, participação e fundamentação: para uma concretização do princípio da imparcialidade administrativa. Coimbra: Almedina, 1996.

FERRAZ, Sérgio; DALLARI, Adilson Abreu. Processo administrativo. $3^{a}$ ed., São Paulo: Editora Malheiros, 2012.

FIGUEIREDO, Lúcia Valle. Curso de direito administrativo. $9^{\text {a }}$ ed., São Paulo: Malheiros Editores, 2008.

FISHKIN, James S. Democracy and Deliberation: New Directions for Democratic Reform. New Haven. Yale University Press. 1991. 
FLEURY, Sônia. Iniciativa Popular. In: AVRITZER, Leonardo; ANASTASIA, Fátima. (Org.). Reforma Política no Brasil. Belo Horizonte: Editora UFMG, 2006, p. 94-102, 2006.

FUKS, Mario; PERISSINOTTO, Renato M.; Souza, Nelson Rosário de (Org.). Democracia e Participação: os Conselhos Gestores do Paraná. Curitiba: Editora UFPR, 2004.

FUNG, Archon. Receitas para esferas públicas: oito desenhos institucionais e suas consequências in COELHO, Vera Schattan P; NOBRE, Marcos (org.) Participação e deliberação: teoria democrática e experiências institucionais no Brasil contemporâneo. São Paulo, Ed. 34, 2004.

GÁRCIA DE ENTERRÍA, Eduardo; FERNÁNDEZ, Tomás-Ramón. Curso de derecho administrativo. 5. ed. Madri: Civitas, 1998. Tomo I.

Curso de direito administrativo. Revisor técnico Carlos Ari Sundfeld; Tradutor José Alberto Froes Cal. São Paulo: Editora Revista dos Tribunais, 2014. Tomo II.

GIACOMONI, James. Orçamento público. 16ª ed. São Paulo: Atlas, 2012.

GOHN, Maria da Glória. Movimentos sociais e luta pela moradia. São Paulo: Loyola, 1991.

Os conselhos municipais e a gestão urbana. In: SANTOS JUNIOR, Orlando Alves dos; RIBEIRO, Luiz Cesar de Queiroz; AZEVEDO, Sérgio de. Governança democrática e poder local: a experiência dos conselhos municipais no Brasil. Rio de Janeiro: Revan, Fase, 2004.

2011.

Conselhos gestores e participação sociopolítica. 4. Ed. São Paulo: Cortez,

GRAU, Eros Roberto. Planejamento Económico e Regra Jurídica. São Paulo: Revista dos Tribunais, 1978.

GRINOVER, Ada Pellegrini; CINTRA, Antônio Carlos Araújo; DINAMARCO, CÂNDIDO Rangel. Teoria Geral do Processo. $31^{\mathrm{a}}$ ed. São Paulo: Malheiros Editores, 2015.

HABERMAS, Jünger. Direito e Democracia - entre facticidade e validade, v.1 e v.2 Rio de Janeiro, Tempo Universitário, 1997.

Mudança estrutural da esfera pública. São Paulo: Editora Unesp, 2014.

HARADA, Kiyoshi. Direito Financeiro e Tributário. 21 ed., Atlas: São Paulo, 2012.

HELD, David. Modelos de Democracia, Belo Horizonte, Paidéia, 1987.

HENRIQUES, Elcio Fiori. Disposição preliminar. In: CONTI, José Maurício Conti (coord.). Orçamentos públicos - a Lei 4.320/1964 comentada. São Paulo: Editora Revista dos Tribunais, 2008.

INSTITUTO BRASILEIRO DE GEOGRAFIA E ESTATÍSTICA - IBGE, Pesquisa de 
Informações Básicas Municipais - 1999/2001. Rio de Janeiro, 2001.

Pesquisa de Informações Básicas Municipais - 2012/2013. Rio de Janeiro,

2013.

JUSTEN FILHO, Marçal. Curso de direito administrativo. $10^{a}$ ed. São Paulo: Revista dos Tribunais. 2014.

KINGDON, John W. Como chega a hora de uma idéia? In: SARAVIA, Enrique; FERRAREZI, Elisabete. Políticas públicas: coletânea. Brasília: ENAP, p. 219-245, 2007.

Agendas, alternatives and public policies. KINGDON, John W. Agendas, alternatives, and public policies. 2. ed. Nova York: Longman Publisher, 2011.

KOWARICK, Lúcio. Viver em Risco: Sobre a Vulnerabilidade Socioeconômica e Civil. São Paulo, Editora 34, 2009.

KOWARICK, Lúcio; BRANT, Vinícius Caldeira (coord.), São Paulo 1975: Crescimento e Pobreza. São Paulo: Edições Loyola, 1976.

KOWARICK, Lúcio; CAMPANÁRIO, Milton. São Paulo: do milagre à crise. Lua Nova, $\mathrm{n}$. 28-29, abril, São Paulo, 1993.

LAVALLE, Adrián Gurza; HOUTZAGER, Peter; CASTELLO, Graziela. Representação política e organizações civis: novas instâncias de mediação e os desafios da legitimidade.

Revista Brasileira de Ciências Sociais, v. 21, n. 60, fev., p. 43-66, 2006.

LIBERATI, Wilson Donizeti, CYRINO, Públio Caio Bessa. Conselhos e Fundos no Estatuto da Criança e do Adolescente, São Paulo: Malheiros Editores, 2003.

LISBOA, Marcos de Barros; LATIF, Zeina Abdel. Democracy and Growth in Brazil. Insper Working Paper, WPE: 311/2013, 2013. Disponível em: $<$ http://www.insper.edu.br/working-papers/working-papers-2013/democracy-and-growthin-brazil/ > . Acesso em: 20 de junho de 2015.

LÜCHMANN, Ligia Helena Hahn. Associações, participação e representação: combinações e tensões. Lua Nova, São Paulo, n. 84, 2011.

LUHMANN, Niklas. Legitimação pelo procedimento. Tradução de Maria da Conceição Côrte-Real. Brasilia: UnB, 1980.

MACEDO, Roberto Sidnei. A etnografia crítica e multirreferencial nas ciências humanas e na educação, Salvador: EDUFBA, 2000.

MARCONI, Maria de Andrade; LAKATOS, Eva Maria. Metodologia científica. 5. Ed., São Paulo: Atlas, 2007.

MARQUES NETO, Floriano Peixoto de Azevedo; Princípios do Processo Administrativo. Fórum Administrativo, Belo Horizonte, v. 37, p. 3505-3512, 2004. 
MARTINS, Gilberto de Andrade. Estudo de Caso: Uma Estratégia de Pesquisa. 2. Ed., São Paulo: Atlas, 2008.

MARTINS, Marcelo Feijó; MARTINS, Simone; OLIVEIRA, Adriel Rodrigues de; SOARES, Jéferson Boechat. Conselhos Municipais de Políticas Públicas: uma análise exploratória. Revista de Serviço Público, n. 59 (2), abr./jun., p. 151-185, 2008.

MARTINS, Maria Lucia Refinetti. Relatório da gestão 2003-2005 do CMH, representação da Universidade / FAUUSP, mimeo, 2005. Disponível em: <http://www.fau.usp.br/fau/administracao/congregacao/documentos/relatorio_gestao_2003 _2005.pdf>. Acesso em: 02 de outubro de 2015.

MASSA-ARZABE, Patrícia Helena. Dimensão jurídica das políticas públicas. In: In: BUCCI, Maria Paula Dallari (Org.). Políticas Públicas: reflexões sobre o conceito jurídico. São Paulo: Saraiva, 2006.

MAZZILli, Hugo Nigro. A defesa dos interesses difusos em juízo: meio ambiente, consumidor, patrimônio cultural, patrimônio público e outros interesses. 21. ed., São Paulo: Saraiva, 2008.

MEDAUAR, Odete. Administração Pública ainda sem democracia. Problemas Brasileiros. v. 23, n. 256, p. 37-53, mar./abr. 1986.

dos Tribunais, 2008.

A processualidade no Direito Administrativo. 2. ed. São Paulo: Revista Administração Pública: do ato ao processo, Fórum Administrativo Direito Público. Belo Horizonte, ano 9, n. 100, p. 167-174, jun., 2009.

Direito administrativo moderno. $18^{\mathrm{a}}$ ed., São Paulo: Revista dos Tribunais, 2014.

MENDES, Denise Cristina Vitale Ramos. Democracia semidireta no Brasil pós-1988: a experiência do Orçamento Participativo. Tese de Doutorado. Faculdade de Direito da Universidade de São Paulo, São Paulo, 2004.

MIGUEL, L. F. Representação política em 3-D: elementos para uma teoria ampliada da representação política. Revista Brasileira de Ciências Sociais, ano XVIII, n. 51, p. 123140, 2003.

MINAYO, Maria Cecília de Souza. O desafio do conhecimento: pesquisa qualitativa em saúde. Rio de. Janeiro: Abrasco, 1992.

MODESTO, Paulo (Coord.). Nova Organização Administrativa Brasileira. $2^{\mathrm{a}}$ ed. Editora Fórum: Belo Horizonte, 2010.

MOREIRA, Egon Bockmann. Processo administrativo. São Paulo: Malheiros Ed., 2010.

MOREIRA, Maria Tarquínia Vieira. Instância deliberativa das políticas públicas de cunho social: contorno jurídico dos Conselhos. In: Informativo CEPAM, Conselhos municipais 
das áreas sociais. 2. Ed. São Paulo: Fundação Prefeito Faria Lima - CEPAM. Unidade de Políticas Públicas, v.1, n. 3, 2002.

MOREIRA NETO, Diogo de Figueiredo. Direito da participação política: legislativa, administrativa, judicial: (fundamentos e técnicas constitucionais da legitimidade). Rio de Janeiro: Renovar, 1992.

1997.

. Audiências públicas. Revista de Direito Administrativo. out/dez., p. 11-23,

Relações entre poderes e democracia: crise e separação. Belo Horizonte:

Fórum, 2014.

Democracia e contrapoderes. Revista de Direito Administrativo, Rio de Janeiro, v. 258, p. 47-80, set./dez. 2011.

MORGADO, Cíntia. Direito à Boa Administração: recíproca dependência entre direitos fundamentais, organização e procedimento, Revista de Direito da Procuradoria Geral, Rio de Janeiro, n. 65, 2010.

MUTZENBERG, Remo. A questão dos movimentos sociais na atualidade. In: MARTINS, Carlos Benedito Martins; Heloísa Helena T. de Souza (coord.). Horizontes das ciências sociais no Brasil: sociologia. São Paulo: ANPOCS, 2010.

NEPAC-Unicamp, Em defesa do Conselho Municipal de Habitação de São Paulo. Le monde diplomatique, 2011. Acessado em 30/04/2014. Disponível em <http://www.diplomatique.org.br/artigo.php?id=1071>.

NETTO, Luísa Cristina Pinto e. Participação administrativa procedimental: natureza jurídica, garantias, riscos e disciplina adequada. Belo Horizonte: Fórum, 2009.

NOBRE, Marcos. Indeterminação e Estabilidade - os 20 anos da Constituição Federal e as tarefas da pesquisa em direito. Novos Estudos, São Paulo, ed. 82, novembro de 2008.

. Participação e deliberação na teoria democrática: uma introdução. In: COELHO, Vera Schattan P.; NOBRE, Marcos (orgs.). Participação e deliberação: teoria democrática e experiências institucionais no Brasil contemporâneo. São Paulo: Ed. 34, 2004.

NUNES, Cleucio Santos. Dos Fundos Especiais. In: CONTI, José Maurício Conti (coord.). Orçamentos públicos - a Lei 4.320/1964 comentada. São Paulo: Editora Revista dos Tribunais, 2008

O’DONNELL, Guillermo. Accountability horizontal e novas poliarquias. Lua Nova, n. 44, p. 27-54, 1998.

OLIVEIRA, Cristiane Catarina Fagundes de. Controle social pelos conselhos municipais e controvérsias jurisprudenciais. Revista da AJURIS, Ano XXXIV, n 108, dez, 2007. p. 3547. 
de Doutorado. Faculdade de Direito da Universidade de São Paulo, São Paulo, 2005.

OLIVEIRA, Gustavo Justino de. Audiências públicas e processo administrativo. Revista de Direito Administrativo, n. 209, ju./set., p. 153-167, 1997.

. Direito administrativo democrático. Belo Horizonte: Fórum, 2010.

. Participação administrativa. Revista Eletrônica sobre Reforma do Estado, n. 3, set./out./nov., 2005. Disponível em: <http://www.direitodoestado.com/revista/RERE3-SETEMBRO-2005-GUSTAVO\%20JUSTINO.pdf >. Acesso em: 05/01/2014.

Governança pública e parcerias do Estado: novas fronteiras do direito administrativo, Revista de Direito da Procuradoria Geral, Rio de Janeiro, (Edição Especial), 2012.

OLIVEIRA, Márcio Luiz de Albuquerque. Participação Social e Políticas Públicas: uma análise sobre a influência do Conanda nos Instrumentos Orçamentários. Mestrado. Faculdade de Administração. Universidade de Brasília, 2014.

OLIVEIRA, Regis Fernandes. Curso de Direito Financeiro. 2. ed. São Paulo: Editora Revista dos Tribunais, 2008.

OLIVEIRA NETO, Sebastião. Situação Prestes Maia: o processo de colaboração entre artistas, coletivos artísticos e o Movimento Sem-Teto do Centro (MSTC). Ocupação Prestes Maia/São Paulo (2003-2007). Dissertação de Mestrado - Programa de Pós-Graduação em Estética e História da Arte da Universidade de São Paulo, São Paulo, 2012.

PAOLI, Maria Célia, TELLES, Vera da Silva. Direitos sociais - conflitos e negociações no Brasil contemporâneo. In: ALVAREZ, Sonia E; DAGNINO, Evelina; ESCOBAR, Arturo (orgs.). Cultura e política nos movimentos sociais latino-americanos. Belo Horizonte, UFMG, 2000, p. 103-148.

PATEMAN, Carole. Participação e teoria democrática; tradução de Luiz Paulo Rouanet. — Rio de Janeiro: Paz e Terra, 1992.

PAZ, Rosângela. A representação da sociedade civil nos Conselhos de Assistência Social. In: CARVALHO, M.C.A.A; TEIXEIRA, A.C.C (Orgs.). Conselhos gestores de políticas públicas. São Paulo, Pólis, 2000, p. 58-62.

PEREZ, Marcos Augusto. Institutos de participação popular na administração pública. Belo Horizonte: Fórum, 2004.

A participação da sociedade na formulação, decisão e execução das políticas públicas. In: BUCCI, Maria Paula Dallari (Org.). Políticas Públicas: reflexões sobre o conceito jurídico. São Paulo: Saraiva, 2006.

PIRES, Maria Coeli Simões. Esgotamento do modelo de desenvolvimento excludente no Brasil e ressemantização das atividades de planejamento e articulação governamentais à luz do paradigma democrático. In: MODESTO, Paulo (Coord.). Nova Organização Administrativa Brasileira. $2^{\text {a }}$ ed. Editora Fórum: Belo Horizonte, 2010. 
PRUDENTE, Eunice A. de Jesus. O direito de participação popular nas Constituições Federal e Estadual e nas Leis Orgânicas dos Municípios da Região Metropolitana da Grande São Paulo. 1993, v.1. 105 p. disponível na Biblioteca do Departamento de Direito do Estado da Faculdade de Direito da Universidade de São Paulo.

RESENDE, Fabrício Contato Lopes. O papel do poder judiciário no controle da implementação de políticas públicas no Brasil - a política assistencial do artigo 20 da Lei n. 8.742/93. Dissertação de Mestrado - Faculdade de Direito da Universidade de São Paulo, São Paulo, 2010.

SADER, Eder. Quando novos personagens entraram em cena. Experiências e lutas dos trabalhadores da Grande São Paulo (1970-1980). Rio de Janeiro: Paz e Terra, 2001.

SÃO PAULO (cidade). Regimento Interno do Conselho Municipal de Saúde de São Paulo. Diário Oficial da Cidade de São Paulo, Poder Executivo, São Paulo, SP, 07 jul. 2000; 18 out. 2000 e 19 out. 2001.

- Regimento Interno do Conselho Municipal de Habitação de São Paulo. Diário Oficial da Cidade de São Paulo. Poder Executivo. São Paulo, 23 out. 2003, p. 23 25. 2003a.

Resolução no 70/03 do Conselho Municipal dos Direitos da Criança e do Adolescente - CMDCA. Diário Oficial da Cidade de São Paulo. Poder Executivo. São Paulo, 09 out. 03, p.53-54. 2003b.

- Regimento Interno dos Grupos de Trabalho do Conselho Municipal de Habitação de São Paulo (Resolução CMH no 44, de 13 de abril de 2010). Diário Oficial da Cidade de São Paulo. Poder Executivo. 14 mai. 10, ano 55, n. 89, p. 50-51. 2010.

- Regimento Interno do Conselho Gestor do Fundo Municipal de Desenvolvimento Urbano - FUNDURB (Resolução ${ }^{\circ}$ 002/2011). Diário Oficial da Cidade de São Paulo. Poder Executivo. 28 jun. 2011, p. 16. 2011.

Informações sobre a elaboração do Programa de Metas de 2013-2016, 2013. Disponível em: < www.planejasampa.prefeitura.sp.gov.br >. Acessado em: 10 abr. 15. 2013a.

. Portaria $n^{\circ}$ 368/SEHAB/2013. Diário Oficial da Cidade de São Paulo. 19 out. 13 , ano 58 , n. 200 , p. 24. 2013 b.

Portaria Intersecretarial 4/13 - SEMPLA/SF. Diário Oficial da Cidade de São Paulo. Poder Executivo. 29 jun. 13, ano 58, p. 01. 2013c.

. Portaria Intersecretarial 03/14 - SEMPLA/SF. Diário Oficial da Cidade de São Paulo. Poder Executivo. 18 jun. 14, ano 59, n. 112. 2014.

. Portaria Intersecretarial 115/15 - SF. Diário Oficial da Cidade de São Paulo. Poder Executivo. 20 jun. 15, p. 113. 2015.

SÃO PAUlO (Estado), Tribunal de Justiça do Estado de São Paulo, Ação Direita de 
Inconstitucionalidade $\mathbf{n}^{0}$ 0207644-30.2011.8.26.0000, Órgão Especial, Relator: Walter de Almeida Guilherme, São Paulo, 21 mar. 2012, 2012.

- Tribunal de Justiça do Estado de São Paulo, Ação Direita de Inconstitucionalidade $\mathbf{n}^{\mathbf{0}}$ 0083103-85.2012.8.26.0000, Órgão Especial, Relator: Antônio Luiz Pires Neto, São Paulo, 23 jan. 13, 2013.

SÁNCHEZ MORÓN, Miguel. La participación del ciudadano en la Administración Pública. Madrid: Centro de Estudos Constitucionales, 1980.

Elementos de la participación ciudadana. Revista de estudios de la vida local, n. 221, jan./mar., p. 37-46, 1984.

SANTAGADA, Salvatore. A situação social do Brasil nos anos 80. Indicadores. Econômicos FEE, v. 17, n. 4, p. 121-143, 1990.

SANTOS, Boaventura de Souza (org.). Democratizar a democracia: os caminhos da democracia participativa. Rio de Janeiro: Civilização Brasileira, 2002.

SANTOS, Fabio Gomes dos. Audiências públicas administrativas no direito brasileiro. São Paulo, 2013, 308 p. Dissertação (Mestrado em Direito). Faculdade de Direito, USP, 2013.

SANTOS JUNIOR, Orlando Alves dos; AZEVEDO, Sergio de; RIBEIRO, Luiz Cesar de Queiroz. Democracia e gestão local: a experiência dos conselhos municipais no Brasil. In: Orlando Alves dos; AZEVEDO, Sergio de; RIBEIRO, Luiz Cesar de Queiroz (Orgs.). Governança democrática e poder local: a experiência dos conselhos municipais no Brasil. Rio de Janeiro: Revan, Fase, 2004.

SARTORI, Giovanni. Teoria da democracia revisitada. São Paulo: Ática, 1994.

SEVERINO, Antônio Joaquim. Metodologia do trabalho científico. 23. ed. São Paulo: Cortez, 2007.

SILVA, Pedro Luiz Barros; MELO, Marcus André Barreto. O processo de implementação de políticas públicas no Brasil: características e determinantes da avaliação de programas e projetos. Caderno no 48. Núcleo de estudos de políticas públicas - NEPP, Universidade de Campinas, 2000. Disponível em: <http://www.nepp.unicamp.br/index.php/publicacoes>. Acesso em 30/04/2015.

SMULOVITZ, Catalina; PERUZZOTTI, Enrique. Societal and horizontal controls: two cases of a fruitful relationship. In: MAINWARING, Scott; WELNA, Christopher. Democratic accountability in Latin America. New York: Oxford University Press, p. 309-331, 2003.

SOUZA, Celina. Políticas Públicas: uma revisão da literatura. Sociologias, Porto Alegre, ano $8, n^{\circ} 16$, jul-dez 2006, p. 20-45.

SUNDFELD, Carlos Ari; MUÑOZ, Guilhermo. Leis de processo administrativo, as (Lei federal 9.784/99 e Lei paulista 10.177/98), $1^{\text {a }}$ ed., $2^{\text {a }}$ tiragem, São Paulo: Malheiros 
Editores, 2006.

TATAGIBA, Luciana Ferreira. Os Conselhos Gestores e a Democratização das Políticas Públicas. In: DAGNINO, Evelina (org.) Sociedade civil e espaços públicos no Brasil. São Paulo: Paz e Terra, 2002.

. Os conselhos e a construção da democracia no Brasil: um rápido balanço de duas décadas de participação conselhista. In: RUBIM, Albino Canelas; FERNANDES, Taiane; RUBIM, Iuri (orgs.). Políticas culturais, democracia e conselhos de cultura. Salvador: Edufba, 2010.

. A questão dos atores, seus repertórios de ação e implicações para o processo participativo. In: Efetividade das instituições participativas no Brasil: estratégias de avaliação/organizador: Roberto Rocha C. Pires. Brasília: Ipea, 2011.

TEIXEIRA, Ana Cláudia Chaves. Identidades em construção: as organizações nãogovernamentais no processo brasileiro de democratização. São Paulo: Annablume, Fapesp, 2003.

Conselhos gestores de políticas públicas e poder legislativo. In: ABRAMO, Z. W.; FRATI, M. Democratização do parlamento: alargando as fronteiras da participação e da representação política. São Paulo: Fundação Perseu Abramo, p. 57-61, 2005.

TEIXEIRA, Elenaldo Celso. Conselhos de políticas públicas: efetivamente uma nova institucionalidade participativa? In: CARVALHO, M.C.A.A; TEIXEIRA, A.C.C (Orgs.). Conselhos gestores de políticas públicas. São Paulo, Pólis, 2000, p. 97-119.

VALENTE, Manoel Adam Lacayo. Democracia enclausurada: um debate crítico sobre a democracia representativa contemporânea. Câmara dos Deputados, Coordenação de Publicações, Brasília, 2006.

VALLE, José Ãngelo Santos do; CAMARGO, Álvaro Antônio Bueno de; MOTA, Edmarson Bacelar; ZYGIELSZYPER, Paula Misan Klajnberg. Gerenciamento de stakeholders em projetos. Rio de Janeiro: Editora FGV, 2014.

VARGAS CÔRTES, Soraya M. Arcabouço histórico-institucional e a conformação de conselhos municipais de políticas. Educar em Revista. Curitiba, n. 25, 2005.

VASCONCELOS, Waleska B. De C. Pós-modernidade e democracia participativa na Administração Pública brasileira. Fórum Administrativo - Direito Público. Belo Horizonte, ano 7, n. 76, p. 27-32, jun., 2007.

VIANA, Ana Luíza. Abordagens metodológicas em políticas públicas. Revista de Administração Pública. n. 2, p. 5-43, mar., 1996.

YIN, Robert. K. Estudo de caso: planejamento e métodos. Tradução Ana Thorell; Revisão técnica Cláudio Damacena. 4 edição. Porto Alegre: Bookmann, 2010. 


\section{APÊNDICE}

\section{APÊNDICE A - Lista das atas de reunião analisadas.}

Legenda: 1) "N/L": ata não localizada; 2) "mimeo": ata não localizada no DOCSP, mas obtida nos arquivos da Secretaria Executiva do CMH.

Atas dispostas em ordem cronológica (consultar pela data da reunião).

\begin{tabular}{|c|c|c|c|c|c|c|c|}
\hline $\begin{array}{l}\text { Total } \\
\text { geral }\end{array}$ & $\begin{array}{c}\text { Por } \\
\text { gestão }\end{array}$ & Gestão & Órgão & Data & Reunião & DOCSP & Pág. \\
\hline 1 & 1 & $2003 / 2005$ & CECMH & 21-jul-03 & $1^{a}$ Reunião Ordinária & 23-out-03 & 23 \\
\hline 2 & 2 & $2003 / 2005$ & $\mathrm{CMH}$ & 25-jul-03 & $1^{\mathrm{a}}$ Reunião Ordinária & 23 -out-03 & 23 \\
\hline 3 & 3 & $2003 / 2005$ & $\mathrm{CMH}$ & 24 -set-03 & $1^{\mathrm{a}}$ Reunião Extraordinária & 27-fev-04 & 54 \\
\hline 4 & 4 & $2003 / 2005$ & $\mathrm{CMH}$ & 20 -out-03 & $2^{\mathrm{a}}$ Reunião Ordinária & 27-fev-04 & 54 \\
\hline 5 & 5 & $2003 / 2005$ & $\mathrm{CMH}$ & 11-nov-03 & $2^{\mathrm{a}}$ Reunião Extraordinária & 27-fev-04 & $54-55$ \\
\hline 6 & 6 & $2003 / 2005$ & $\mathrm{CMH}$ & 21-nov-03 & $3^{\mathrm{a}}$ Reunião Extraordinária & 27-fev-04 & 55 \\
\hline 7 & 7 & $2003 / 2005$ & CECMH & 26-nov-03 & $2^{\mathrm{a}}$ Reunião Ordinária & 27 -abr-04 & 59 \\
\hline 8 & 8 & $2003 / 2005$ & $\mathrm{CMH}$ & 12-dez-03 & $4^{a}$ Reunião Extraordinária & 27-fev-04 & $55-56$ \\
\hline 9 & 9 & $2003 / 2005$ & $\mathrm{CMH}$ & $\mathrm{N} / \mathrm{L}$ & $\begin{array}{c}5^{\mathrm{a}} \text { Reunião Extraordinária } \\
-\mathrm{N} / \mathrm{L}\end{array}$ & $\mathrm{N} / \mathrm{L}$ & $\mathrm{N} / \mathrm{L}$ \\
\hline 10 & 10 & $2003 / 2005$ & $\mathrm{CMH}$ & 30-jan-04 & $3^{\mathrm{a}}$ Reunião Ordinária & 27-abr-04 & $59-60$ \\
\hline 11 & 11 & $2003 / 2005$ & CECMH & 10 -fev-04 & $3^{\text {a }}$ Reunião Ordinária & 27-abr-04 & 59 \\
\hline 12 & 12 & $2003 / 2005$ & $\mathrm{CMH}$ & 29-mar-04 & $4^{a}$ Reunião Ordinária & 6-nov-04 & 16 \\
\hline 13 & 13 & $2003 / 2005$ & CECMH & 1-mai-04 & $4^{a}$ Reunião Ordinária & 28-dez-04 & $35-36$ \\
\hline 14 & 14 & $2003 / 2005$ & $\mathrm{CMH}$ & 8-jun-04 & $5^{\text {a }}$ Reunião Ordinária & 6-nov-04 & 16 \\
\hline 15 & 15 & $2003 / 2005$ & $\mathrm{CMH}$ & 30-jun-04 & $6^{\mathrm{a}}$ Reunião Extraordinária & 6-nov-04 & 17 \\
\hline 16 & 16 & $2003 / 2005$ & CECMH & 7-jul-04 & $5^{\text {a }}$ Reunião Ordinária & 28-dez-04 & 36 \\
\hline 17 & 17 & $2003 / 2005$ & $\mathrm{CMH}$ & 13 -ago-04 & $6^{\mathrm{a}}$ Reunião Ordinária & 7-mai-05 & 34 \\
\hline
\end{tabular}




\begin{tabular}{|c|c|c|c|c|c|c|c|}
\hline 18 & 18 & $2003 / 2005$ & $\mathrm{CMH}$ & 6-out-04 & $7^{\mathrm{a}}$ Reunião Ordinária & 7-mai-05 & $34-35$ \\
\hline 19 & 19 & $2003 / 2005$ & CECMH & 9-nov-04 & $6^{a}$ Reunião Ordinária & 28-dez-04 & 36 \\
\hline 20 & 20 & $2003 / 2005$ & $\mathrm{CMH}$ & 19-nov-04 & $7^{a}$ Reunião Extraordinária & 7-mai-05 & 35 \\
\hline 21 & 21 & $2003 / 2005$ & $\mathrm{CMH}$ & 7-dez-04 & $8^{a}$ Reunião Ordinária & 7-mai-05 & $35-36$ \\
\hline 22 & 22 & $2003 / 2005$ & CECMH & 16-dez-04 & $7^{a}$ Reunião Ordinária & mimeo & - \\
\hline 23 & 23 & $2003 / 2005$ & $\mathrm{CMH}$ & 23-mar-05 & $9^{a}$ Reunião Ordinária & mimeo & - \\
\hline 24 & 24 & $2003 / 2005$ & $\mathrm{CMH}$ & 30-mai-05 & $10^{\mathrm{a}}$ Reunião Ordinária & mimeo & - \\
\hline 25 & 25 & $2003 / 2005$ & $\mathrm{CMH}$ & 22-jun-05 & $8^{\mathrm{a}}$ Reunião Extraordinária & mimeo & - \\
\hline 26 & 1 & $2005 / 2007$ & $\mathrm{CMH}$ & 18-nov-05 & $1^{\mathrm{a}}$ Reunião Ordinária & mimeo & - \\
\hline 27 & 2 & $2005 / 2007$ & СЕСMH & 2-fev-06 & $1^{\mathrm{a}}$ Reunião Ordinária & mimeo & - \\
\hline 28 & 3 & $2005 / 2007$ & $\mathrm{CMH}$ & 22-fev-06 & $2^{\mathrm{a}}$ Reunião Ordinária & 3-jun-06 & $21-22$ \\
\hline 29 & 4 & $2005 / 2007$ & $\mathrm{CMH}$ & 24-mai-06 & $3^{\mathrm{a}}$ Reunião Ordinária & 29-jul-06 & $19-21$ \\
\hline 30 & 5 & $2005 / 2007$ & CECMH & 28-jun-06 & $2^{\mathrm{a}}$ Reunião Ordinária & 1 -set-06 & $34-35$ \\
\hline 31 & 6 & $2005 / 2007$ & $\mathrm{CMH}$ & 26-jul-06 & $4^{\mathrm{a}}$ Reunião Ordinária & 10 -out-06 & $19-21$ \\
\hline 32 & 7 & $2005 / 2007$ & CECMH & 30-ago-06 & $3^{\mathrm{a}}$ Reunião Ordinária & 23-nov-06 & $19-20$ \\
\hline 33 & 8 & $2005 / 2007$ & $\mathrm{CMH}$ & 28 -set-06 & 5a Reunião Ordinária & 5-mai-07 & $25-27$ \\
\hline 34 & 9 & $2005 / 2007$ & CECMH & 8-nov-06 & $4^{\mathrm{a}}$ Reunião Ordinária & 5-mai-07 & $23-25$ \\
\hline 35 & 10 & $2005 / 2007$ & $\mathrm{CMH}$ & 19-mar-07 & $6^{a}$ Reunião Ordinária & 17-mai-07 & $27-30$ \\
\hline 36 & 11 & $2005 / 2007$ & CECMH & 19-abr-07 & $5^{\mathrm{a}}$ Reunião Ordinária & mimeo & - \\
\hline 37 & 12 & $2005 / 2007$ & $\mathrm{CMH}$ & 8-mai-07 & $7^{\text {a }}$ Reunião Ordinária & 27-mai-08 & $26-28$ \\
\hline 38 & 13 & $2005 / 2007$ & CECMH & 20-jun-07 & $6^{a}$ Reunião Ordinária & 25 -set- 07 & $19-20$ \\
\hline 39 & 14 & $2005 / 2007$ & $\mathrm{CMH}$ & 14 -set-07 & $8^{a}$ Reunião Ordinária & 17-out-07 & 25 \\
\hline 40 & 1 & $2007 / 2009$ & $\mathrm{CMH}$ & 16-jan-08 & $1^{a}$ Reunião Ordinária & 26-mar-08 & 25 \\
\hline 41 & 2 & $2007 / 2009$ & CECMH & 29-fev-08 & $1^{a}$ Reunião Ordinária & 22-ago-08 & $18-19$ \\
\hline 42 & 3 & $2007 / 2009$ & $\mathrm{CMH}$ & 19-mar-08 & $2^{\mathrm{a}}$ Reunião Ordinária & 19-abr-08 & $28-29$ \\
\hline 43 & 4 & $2007 / 2009$ & CECMH & $15-a b r-08$ & $2^{\mathrm{a}}$ Reunião Ordinária & 2-jul-08 & $22-23$ \\
\hline 44 & 5 & 2007/2009 & $\mathrm{CMH}$ & 17-jun-08 & $3^{a}$ Reunião Ordinária & 12-ago-08 & $24-25$ \\
\hline
\end{tabular}




\begin{tabular}{|c|c|c|c|c|c|c|c|}
\hline 45 & 6 & $2007 / 2009$ & CECMH & 30-jun-08 & $3^{\mathrm{a}}$ Reunião Ordinária & 22-ago-08 & 19 \\
\hline 46 & 7 & $2007 / 2009$ & $\mathrm{CMH}$ & 6-ago-08 & $4^{\mathrm{a}}$ Reunião Ordinária & 2-out-08 & $51-52$ \\
\hline 47 & 8 & $2007 / 2009$ & CECMH & 19-ago-08 & $4^{\mathrm{a}}$ Reunião Ordinária & 9-abr-09 & $80-81$ \\
\hline 48 & 9 & $2007 / 2009$ & $\mathrm{CMH}$ & 17 -set-08 & $5^{\text {a }}$ Reunião Ordinária & 16-dez-08 & $30-32$ \\
\hline 49 & 10 & $2007 / 2010$ & CECMH & 29-set-08 & $1^{\text {a }}$ Reunião Extraordinária & 9-abr-09 & $79-80$ \\
\hline 50 & 11 & $2007 / 2009$ & CECMH & 21-out-08 & $5^{\text {a }}$ Reunião Ordinária & 10-abr-09 & 71 \\
\hline 51 & 12 & 2007/2009 & $\mathrm{CMH}$ & 19-nov-08 & $6^{a}$ Reunião Ordinária & 28 -abr-09 & $54-55$ \\
\hline 52 & 13 & $2007 / 2009$ & CECMH & 16-dez-08 & $6^{a}$ Reunião Ordinária & 9-abr-09 & $78-79$ \\
\hline 53 & 14 & 2007/2009 & $\mathrm{CMH}$ & $11-m a r-09$ & $7^{\text {a }}$ Reunião Ordinária & 19-mai-09 & $74-75$ \\
\hline 54 & 15 & $2007 / 2009$ & CECMH & 7-abr-09 & $7^{a}$ Reunião Ordinária & 12-nov-09 & $57-58$ \\
\hline 55 & 16 & $2007 / 2009$ & $\mathrm{CMH}$ & 13-mai-09 & $8^{\text {a }}$ Reunião Ordinária & 25-jul-09 & $63-64$ \\
\hline 56 & 17 & $2007 / 2009$ & CECMH & 16-jun-09 & $8^{\mathrm{a}}$ Reunião Ordinária & 25 -ago-09 & $51-52$ \\
\hline 57 & 18 & 2007/2009 & $\mathrm{CMH}$ & 15-jul-09 & $9^{a}$ Reunião Ordinária & 22 -set-09 & $59-61$ \\
\hline 58 & 19 & $2007 / 2009$ & CECMH & 18-ago-09 & $9^{a}$ Reunião Ordinária & 4-mar-10 & 25 \\
\hline 59 & 20 & 2007/2009 & $\mathrm{CMH}$ & 16 -set-09 & $10^{\mathrm{a}}$ Reunião Ordinária & 12 -fev-10 & $57-58$ \\
\hline 60 & 1 & $2009 / 2011$ & $\mathrm{CMH}$ & 29-jan-10 & $1^{a}$ Reunião Ordinária & 24-mar-10 & 141- \\
\hline 61 & 2 & $2009 / 2011$ & CECMH & $23-f e v-10$ & $1^{\mathrm{a}}$ Reunião Ordinária & 15 -abr- 10 & $65-66$ \\
\hline 62 & 3 & $2009 / 2011$ & $\mathrm{CMH}$ & 18 -mar-10 & $2^{\mathrm{a}}$ Reunião Ordinária & 2-jun-10 & $61-63$ \\
\hline 63 & 4 & $2009 / 2011$ & СЕСМH & 13 -abr-10 & $2^{\mathrm{a}}$ Reunião Ordinária & 24-jul-10 & 73-74 \\
\hline 64 & 5 & $2009 / 2011$ & $\mathrm{CMH}$ & 20-mai-10 & $3^{\mathrm{a}}$ Reunião Ordinária & 18 -set-10 & $91-93$ \\
\hline 65 & 6 & $2009 / 2011$ & $\mathrm{CMH}$ & 24-jun-10 & $1^{a}$ Reunião Extraordinária & 18 -set-10 & 93-94 \\
\hline 66 & 7 & 2009/2011 & CECMH & 22-jul-10 & $3^{\mathrm{a}}$ Reunião Ordinária & 25 -ago-10 & $\begin{array}{l}134- \\
135\end{array}$ \\
\hline 67 & 8 & $2009 / 2011$ & CECMH & 19-ago-10 & $4^{\mathrm{a}}$ Reunião Ordinária & 22-out-10 & $65-66$ \\
\hline 68 & 9 & $2009 / 2011$ & $\mathrm{CMH}$ & 16 -set-10 & $4^{\mathrm{a}}$ Reunião Ordinária & 20-nov-10 & 78 \\
\hline 69 & 10 & $2009 / 2011$ & CECMH & 19-out-10 & $5^{a}$ Reunião Ordinária & $1-a b r-11$ & $53-54$ \\
\hline 70 & 11 & $2009 / 2011$ & $\mathrm{CMH}$ & 18-nov-10 & $5^{\text {a }}$ Reunião Ordinária & 4-mar-11 & $61-62$ \\
\hline
\end{tabular}




\begin{tabular}{|c|c|c|c|c|c|c|c|}
\hline 71 & 12 & $2009 / 2011$ & $\mathrm{CMH}$ & 24-fev-11 & $6^{a}$ Reunião Ordinária & 5-mai-11 & $53-55$ \\
\hline 72 & 13 & $2009 / 2011$ & CECMH & 29-mar-11 & $6^{a}$ Reunião Ordinária & 2-jun-11 & $53-54$ \\
\hline 73 & 14 & $2009 / 2011$ & $\mathrm{CMH}$ & 29-abr-11 & $7^{a}$ Reunião Ordinária & 30-ago-11 & $68-60$ \\
\hline 74 & 15 & $2009 / 2011$ & CECMH & 31-mai-11 & $7^{a}$ Reunião Ordinária & 29-jul-11 & 59 \\
\hline 75 & 16 & $2009 / 2011$ & CECMH & 26-jul-11 & $8^{\mathrm{a}}$ Reunião Ordinária & 3-dez-11 & $44-45$ \\
\hline 76 & 17 & $2009 / 2011$ & $\mathrm{CMH}$ & 25-ago-11 & $8^{a}$ Reunião Ordinária & 4-nov-11 & $66-67$ \\
\hline 77 & 18 & $2009 / 2011$ & $\mathrm{CMH}$ & 27-out-11 & $9^{a}$ Reunião Ordinária & 2 -ago-14 & $51-53$ \\
\hline 78 & 19 & $2009 / 2011$ & CECMH & 29-nov-11 & $9^{\mathrm{a}}$ Reunião Ordinária - N/L & $\mathrm{N} / \mathrm{L}$ & $\mathrm{N} / \mathrm{L}$ \\
\hline 79 & 20 & $2009 / 2011$ & CECMH & 29-nov-11 & $\begin{array}{c}9^{\text {a }} \text { Reunião Ordinária } \\
\text { (Extrato da ata) }\end{array}$ & 3-dez-11 & 45 \\
\hline 80 & 1 & $2014 / 2016$ & $\mathrm{CMH}$ & 1-ago-14 & $1^{a}$ Reunião Ordinária & 2 -set-14 & $80-82$ \\
\hline 81 & 2 & $2014 / 2016$ & CECMH & 19-ago-14 & $1^{\text {a }}$ Reunião Ordinária & 15 -out-14 & $48-49$ \\
\hline 82 & 3 & $2014 / 2016$ & $\mathrm{CMH}$ & 28-ago-14 & $1^{a}$ Reunião Extraordinária & 27 -set-14 & $63-65$ \\
\hline 83 & 4 & $2014 / 2016$ & $\mathrm{CMH}$ & 25 -set-14 & $2^{\mathrm{a}}$ Reunião Ordinária & 21-out-14 & $89-91$ \\
\hline 84 & 5 & $2014 / 2016$ & CECMH & 14-out-14 & $2^{\mathrm{a}}$ Reunião Ordinária & 9-dez-14 & $81-82$ \\
\hline 85 & 6 & $2014 / 2016$ & $\mathrm{CMH}$ & 16-out-14 & $2^{\mathrm{a}}$ Reunião Extraordinária & 9-dez-14 & $82-84$ \\
\hline 86 & 7 & $2014 / 2016$ & CECMH & 26-nov-14 & $3^{a}$ Reunião Ordinária & 25-mar-15 & 52 \\
\hline 87 & 8 & $2014 / 2016$ & $\mathrm{CMH}$ & 27-nov-14 & $3^{\mathrm{a}}$ Reunião Ordinária & 24-jan-15 & $\begin{array}{l}173- \\
175\end{array}$ \\
\hline 88 & 9 & $2014 / 2016$ & $\mathrm{CMH}$ & 22-jan-15 & $4^{\mathrm{a}}$ Reunião Ordinária & 25 -abr-15 & $\begin{array}{l}119- \\
121\end{array}$ \\
\hline 89 & 10 & $2014 / 2016$ & CECMH & 24-mar-15 & $4^{\mathrm{a}}$ Reunião Ordinária & 21-mai-15 & 53 \\
\hline 90 & 11 & $2014 / 2016$ & $\mathrm{CMH}$ & $23-a b r-15$ & $5^{\text {a }}$ Reunião Ordinária & 30-mai-15 & $79-80$ \\
\hline 91 & 12 & $2014 / 2016$ & CECMH & 19-mai-15 & $5^{\text {a }}$ Reunião Ordinária & 23-jul-15 & 66 \\
\hline 92 & 13 & $2014 / 2016$ & $\mathrm{CMH}$ & 28-mai-15 & $3^{a}$ Reunião Extraordinária & 27-jun-15 & 67 \\
\hline 93 & 14 & $2014 / 2016$ & $\mathrm{CMH}$ & 25-jun-15 & $6^{a}$ Reunião Ordinária & 29-ago-15 & 74 \\
\hline 94 & 15 & $2014 / 2016$ & CECMH & 21-jul-15 & $6^{a}$ Reunião Ordinária & 22-ago-15 & 134 \\
\hline 95 & 16 & $2014 / 2016$ & CECMH & 20 -ago-15 & $1^{a}$ Reunião Extraordinária & 24 -set-15 & 75 \\
\hline
\end{tabular}

